\author{
UNIVERSIDADE DE SÃO PAULO \\ FACULDADE DE FILOSOSFIA, LETRAS E CIÊNCIAS HUMANAS \\ DEPARTAMENTO DE GEOGRAFIA \\ PROGRAMA DE PÓS-GRADUAÇÃO EM GEOGRAFIA HUMANA
}

MÁRCIA CRISTINA BERGAMIN

Da penúria ao sucesso econômico: o processo de formação e desenvolvimento territorial de Santa Maria de Jetibá no Espírito Santo 


\author{
UNIVERSIDADE DE SÃO PAULO \\ FACULDADE DE FILOSOSFIA, LETRAS E CIÊNCIAS HUMANAS \\ DEPARTAMENTO DE GEOGRAFIA \\ PROGRAMA DE PÓS-GRADUAÇÃO EM GEOGRAFIA HUMANA
}

\title{
Da penúria ao sucesso econômico: o processo de formação e desenvolvimento territorial de Santa Maria de Jetibá no Espírito Santo
}

\author{
Márcia Cristina Bergamin
}

Tese apresentada ao Programa de PósGraduação em Geografia Humana do Departamento de Geografia da Faculdade de Filosofia, Letras e Ciências Humanas da Universidade de São Paulo, para a obtenção do título de Doutor em Geografia.

Orientador: Profa. Dra. Sandra Lencioni

São Paulo 2015 


\section{RESUMO}

Esta tese aborda o processo de formação territorial e de crescimento econômico de Santa Maria de Jetibá, um município do Espírito Santo. Objetiva-se, então, compreender o processo de transformação de Santa Maria de Jetibá, que vai de um longo período de penúria dos agricultores ao crescimento econômico recente. Produzindo alimentos, o município conquistou o maior valor adicionado da agropecuária do Espírito Santo e destaca-se como o segundo maior produtor de ovos do país e no âmbito estadual como produtor de alimentos orgânicos e hortaliças. Buscou-se identificar as condicionantes materiais e imateriais que foram determinantes no processo de formação e transformação desse território e que explicam o seu crescimento econômico. O trabalho de campo foi organizado em duas partes. Na primeira, tomando como referência o processo de trabalho, segundo Marx, e suas alterações decorrentes da incorporação de tecnologias, foram elaborados roteiros de entrevistas. Entrevistou-se agricultores familiares e não familiares e diferentes tipos de avicultores. $\mathrm{Na}$ segunda, para entender a estruturação das principais atividades econômica, entrevistou-se representantes de instituições pertinentes ao objetivo da tese. Identificou-se como condicionante imaterial a dimensão ética do trabalho dos pomeranos e seus descendentes, os quais sempre apresentaram severa disciplina para o trabalho que os diferenciava dos demais imigrantes europeus. Tal ética tornou-se uma qualidade desse grupo humano que por ser proveniente de uma província onde não teve acesso a propriedade da terra e por não ter uma nação que o representasse, encontrou na migração para esse território uma possibilidade de crescer economicamente por meio do trabalho. Além disso, a experiência com atividades comerciais de um determinado grupo de avicultores, contribuiu para a estruturação de uma cadeia produtiva com elevado nível de verticalização, que conferiu caráter competitivo à atividade, mesmo em um contexto produtivo desfavorável. Como condicionantes materiais destacam-se: a construção de estradas interligando Santa Maria de Jetibá a importantes centros consumidores e a introdução e ampliação da rede de energia elétrica na zona rural, duas condições gerais de produção fundamentais para as atividades agropecuárias; a modernização da agricultura, que disponibilizou crédito, insumos e meios de produção modernos; a evolução constante das inovações tecnológicas voltadas para a agropecuária, sempre ampliando a produtividade e reduzindo o tempo de produção; a ampliação do mercado consumidor em função da industrialização e da urbanização do estado; a abertura do mercado que permitiu importar as inovações que automatizaram a avicultura de postura; as condições naturais favoráveis à produção de hortaliças e de ovos e a proximidade de grandes centros consumidores. Constatou-se também, que existem importantes diferenças tecnológicas entre a avicultura de postura e a produção de hortaliças convencionais e orgânicas. Enquanto na primeira, constituída somente por um produto, grande parte das barreiras impostas pela natureza à reprodução do capital foi eliminada pelas inovações técnicas, na segunda, constituída por inúmeras variedades de cultivos, muitas barreiras naturais ainda permanecem. Assim, na avicultura de postura predominam granjas de porte grande e o trabalho assalariado, enquanto a produção de hortaliças ocorre em pequenas propriedades e assentada no trabalho familiar.

Palavras-chave: processo de trabalho, inovações técnicas, agricultura familiar, horticultura, avicultura de postura e agricultura orgânica. 


\section{ABSTRACT}

These thesis approach the process of territorial formation and grow of Santa Maria De Jetiba a town in the State of Espirito Santo. Hence the goal is to understand the process of transformation of Santa Maria de Jetiba from a long period of hardship to the recently farmers economic grow. Producing food, the town conquer a high value of agriculture in the State and stands out as a second major on eggs production, also producing organic food and vegetables in the State. The identification of material and non-material elements, it was crucial for the process formation of the territory and transformation, explaining the economic growth. The fieldwork it was organized in to two parts. The fist part taking reference on the working process by Marx,and alterations as a result of the technology introduction, with elaboration of interview to farmers family members and non family members also to poultry farmers. The second part was to understand about the structure of the major economic activities, representatives of institutions related to the thesis goal. It was identified the ethical work dimension of the pomeranos and descendants, always demonstrating severe work discipline that made them standout from others european imigrants. That ethic it was a quality, despite the fact that they did not have land access and for not having a nation represented. The migration to this territory it was a possibility of economic grow through work. In addition the poultry farmers experience for commercial activities, contributed with a structure for a production chain and high level of verticality given a competitive character to the activities. Even without a favorable production context. For instance some material elements should be consider: road construction connecting Santa Maria De Jetiba to consumers majors centers ,implantation and extending of power lines in rural district are key conditions for production and agriculture, credit availability, components and modern production, constant technology evolution, innovation in agriculture, increasing productivity and decreasing production time, growth of consumers as a result from the State industrialization and urbanization, the open market that brings innovations to the automation in poultry laying, favorable natural conditions for vegetables and eggs production, close to major consumers centers. It was possible to noted the difference in technology from poultry laying and conventional vegetables and organics production. The fist constitute only by one product, the technical innovations eliminates natural barriers. On the second, because of variety of cultures, natural barriers still present. Therefore, in poultry laying the farms are predominantly bigger, the workers get paid a fixed amount of money monthly, in vegetables production the farms are smaller and the work are made by the family.

Key words: work process, technical innovations agricultural family, horticulture, aviculture laying, organic agriculture. 


\section{SUMÁRIO}

INTRODUÇÃO

1 FORMAÇÃO TERRITORIAL DE SANTA MARIA DE JETIBÁ NO ÂMBITO DA COLÔNIA DE SANTA LEOPOLDINA

1.1 Imigração europeia para o Espírito Santo e a pequena propriedade rural

1.2 As colônias de imigrantes e a abolição da escravidão

1.3 A colônia imperial de Santa Leopoldina

1.4 A chegada dos imigrantes na colônia de Santa Leopoldina e o início da formação do território que constituirá Santa Maria de Jetibá ...

2 A TRANSIÇÃO DA PENÚRIA PARA O INÍCIO DO CRESCIMENTO ECONÔMICO: O DECLÍNIO DE SANTA LEOPOLDINA E A EMERGÊNCIA DE JETIBÁ E GARRAFÃO, DISTRITOS QUE FORMARÃO O MUNICÍPIO DE SANTA MARIA DE JETIBÁ

2.1 A estrada concorre com o rio: fim do monopólio fluvial do transporte e a decadência de Santa Leopoldina nos anos 1930

2.2 Transformações estruturais do Espírito Santo e suas manifestações em Santa Maria de Jetibá: crise da estrutura produtiva, erradicação dos cafezais, modernização da agricultura e industrialização da Grande Vitória

2.2.1 Crise da estrutura produtiva e seus limites de produção

2.2.2 Erradicação dos cafezais: ampla adesão dos agricultores

2.2.3 Modernização da agricultura: um processo violento

2.2.4 Urbanização e industrialização

2.2.5 Manifestações das transformações estruturais do Espírito Santo em Santa Maria de Jetibá

3 AVICULTURA DE POSTURA EM SANTA MARIA DE JETIBÁ: UMA PRODUÇÃO DETERMINADA PELAS GRANJAS DE PORTE GRANDE E MODERNAS TECNOLOGICAMENTE

3.1 O surgimento da avicultura de postura e a fundação da cooperativa de avicultores na década de 1960

3.2 Incorporação de inovações tecnológicas na avicultura de postura e o processo produtivo do ovo: da pequena produção a produção industrial de ovos

3.3 A estruturação da cadeia produtiva da avicultura de postura e as principais condicionantes do êxito econômico da atividade

3.4 A avicultura de postura como indutora do crescimento econômico de Santa Maria de Jetibá

4 A PRODUÇÃo AGRÍCOLA DE SANTA MARIA DE JETIBÁ E SUAS DETERMINAÇÕES: UMA GRANDE PRODUÇÃO DE HORTALIÇAS ASSENTADA NO TRABALHO FAMILIAR E NA PEQUENA PROPRIEDADE, MAS INTENSAMENTE SUBORDINADA AO COMÉRCIO

4.1 Introdução e expansão da horticultura comercial em Santa Maria de Jetibá 
4.2 Relações de trabalho na produção agrícola: o predomínio da mão de obra familiar e a supervalorização do trabalho

4.3 Meios de produção

4.3.1 A propriedade fundiária: o predomínio da pequena propriedade historicamente constituída

4.3.2 Progresso técnico: incorporação e sujeição ........................................... 146

4.4 Infraestrutura do espaço rural e das propriedades agrícolas ...................... 155

4.5 Expansão do mercado e persistência da subordinação ao comércio............ 158

4.6 O surgimento e o desenvolvimento da agricultura orgânica em Santa Maria de Jetibá

4.6.1 Histórico da agricultura orgânica em Santa Maria de Jetibá .................. 161

4.6.2 O processo de trabalho da agricultura orgânica ................................... 170

4.6.3 O produto orgânico e suas estratégias de comercialização: o predomínio da venda direta ao consumidor ......................................................... 174

5 CONSIDERAÇÕES FINAIS .............................................................. 179

6 REFERÊNCIAS BIBLIOGRÁFICAS ........................................................ 186 


\section{LISTA DE ILUSTRAÇÕES}

Figura 1 - Croqui da colônia imperial de Santa Leopoldina 19

Figura 2 - Sede de Santa Leopoldina ....................................................... 24

Figura 3 - Cadeia de Comercialização ……….......................................... 26

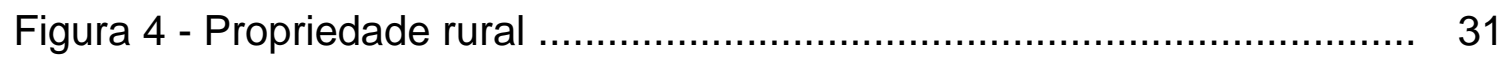

Figura 5 - Mapa Planaltimétrico............................................................ 37

Figura 6 - Municípios criados a partir do desmembramento direto ou indireto de Santa Leopoldina ............................................................................ 42

Figura 7 - Santa Leopoldina: evolução das áreas desmembradas para a criação de novos municípios ................................................................ 44

Figura 8 - Granja manual .............................................................. 96

Figura 9 - Galpão de cria automatizado e vacinação das pintainhas ............ 101

Figura 10 - Galpão de recria automatizado ............................................ 101

Figura 11 - Descedores verticais de ovos .............................................. 103

Figura 12 - Cintas coletoras de esterco ……………................................ 103

Figuras 13 e 14 - Classificação e empacotamento dos ovos ........................ 104

Figura 15 - Evolução da produção de ovos de Santa Maria de Jetibá de 1989 até 2014

Figura 16 - Quadro avicultura de postura

Figura 17 - Santa Maria de Jetibá: Participação das atividades agrícolas por valor bruto da produção (2006)

Figura 18 - Preparação do solo ............................................................. 150

Figura 19 - Santa Maria de Jetibá: principais estradas de acesso ao município 156

Figura 20 - Paisagem rural: revela a existência de pequenas propriedades e um rural povoado. É possível identificar algumas casas que mostram uma certa proximidade entre as sedes das propriedades

Figura 21 e 22 - Manejo pós colheita em locais improvisados ....................... 158

Figura 23 - Caixa de concreto para lavagem de tubérculos .......................... 158 


\section{LISTA DE TABELAS}

Tabela 1 - ESPÍRITO SANTO: imigração estrangeira (1847 - 1900)

Tabela 2 - Exportações de café das colônias de Rio Novo e Santa Leopoldina, $1875 / 1885$

Tabela 3 - Colônia de Santa Leopoldina: entradas de imigrantes por procedência e ano (1857 a 1882)

Tabela 4 - Espírito Santo: indicadores das propriedades rurais

Tabela 5 - Estimativa de reocupação das terras liberadas pela erradicação do café nos principais Estados produtores

Tabela 6 - Espírito Santo: evolução da população rural e urbana (1940-1980)

Tabela 7 - Brasil e Espírito Santo: Indicadores de incorporação de inovações técnicas pelas propriedades rurais (1960 a 1985)

Tabela 8 - Brasil e Espírito Santo: Evolução do percentual de propriedades rurais inferiores a 50 ha e sua participação na distribuição do crédito rural ...... Tabela 9 - Espírito Santo: evolução de algumas atividades agrícolas (19601985)

Tabela 10 - Espírito Santo: evolução da pecuária bovina e da avicultura (19601985)

Tabela 11 - Espírito Santo: Composição Setorial do PIB - 1960-1990

Tabela 12 - Espírito Santo e Grande Vitória: evolução demográfica

Tabela 13 - Evolução da população do território de Santa Maria de Jetibá (1940/1980)

Tabela 14 - Espírito Santo e Santa Leopoldina: evolução da produtividade da cafeicultura - 1960/1985 (T/ha)

Tabela 15 - Santa Leopoldina: evolução de algumas atividades agropecuárias (1960-1985)

Tabela 16 - Santa Leopoldina: indicadores de modernização (1960/1985).......

Tabela 17 - Ciclo reprodutivo da galinha caipira de acordo com as fases reprodutivas

82

Tabela 18 - População Rural e Urbana (2010)

Tabela 19 - Santa Maria de Jetibá: indicadores de escolaridade - 2010

Tabela 20 - Brasil, Espírito Santo e Santa Maria de Jetibá: estrutura fundiária $-2006$

Tabela 21 - Santa Maria de Jetibá: estrutura fundiária (1995/96 e 2006)

Tabela 22 - Alimentos com concentração de agrotóxicos insatisfatória (\%) 2011/2012

Tabela 23 - Preços dos alimentos orgânicos e convencionais (valores em reais) 


\section{INTRODUÇÃO}

Santa Maria de Jetibá é um município de colonização europeia, onde predominam descendentes de imigrantes pomeranos. O município está localizado na região serrana do Espírito Santo, distante a $80 \mathrm{~km}$ da capital estadual. A partir dos anos 2000 o município passou a ter o maior valor adicionado bruto da agropecuária estadual, produzindo ovos e hortaliças. No entanto, há mais de um século a cafeicultura é a principal atividade agrícola do estado e voltada para o mercado externo.

Diferenciando-se, na terra da cafeicultura, o município conquista o maior valor adicionado da produção agropecuária estadual produzindo alimentos para o mercado interno. Além disso, a avicultura de postura que é a principal atividade agrícola de Santa Maria de Jetibá, tem custos de produção mais elevados que os principais estados produtores de ovos por estar muito distante das principais regiões produtoras das matérias-primas da ração.

Mesmo em um contexto produtivo que inicialmente se mostra desfavorável para o desenvolvimento da avicultura de postura, o município tornou-se o segundo maior produtor de ovos do país. No âmbito estadual, Santa Maria de Jetibá é também o maior produtor de alimentos orgânicos e de hortaliças.

Antes do município se tornar um importante produtor agropecuário, remetendo ao início da formação de seu território, quando ainda era parte de uma colônia imperial, a realidade produtiva era bastante diferente da atual. Por mais de um século, grande parte dos agricultores familiares não produzia muito mais do que o necessário para assegurar somente a reprodução simples. Em vários aspectos, as condições de vida dos agricultores familiares se aproximavam do estado de penúria. Somente a partir de 1960 é que essa realidade efetivamente começa a se modificar.

Considerando o longo período de penúria e o contexto produtivo aparentemente desfavorável, por que nos últimos anos Santa Maria de Jetibá cresceu economicamente, destacando-se não somente em nível estadual, mas também nacional? Quais são as principais condicionantes que explicam seu o êxito econômico? Por que o crescimento econômico ocorreu justamente em Santa Maria de Jetibá e não em outro município do entorno, cujo contexto espacial é semelhante? 
Nessa perspectiva, o objetivo central dessa tese consiste em compreender o processo de transformação de Santa Maria de Jetibá, que vai de um longo período de penúria dos agricultores ao crescimento econômico recente. Para tanto, buscouse identificar as condicionantes materiais e imateriais que foram determinantes no processo de formação e transformação desse território e que também explicam o seu crescimento econômico.

Parte-se do princípio que no processo de apropriação desse território, que hoje corresponde ao município de Santa Maria de Jetibá algumas condicionantes materiais e imateriais foram determinantes para o seu crescimento econômico. Dentre as condicionantes materiais ressaltam-se as seguintes: a construção de estradas, a modernização da agricultura, a ampliação do mercado consumidor em função da urbanização, a automação da avicultura e as condições naturais. Como condicionantes imateriais destacam -se a extrema valorização do trabalho pelo principal grupo humano que produziu Santa Maria de Jetibá, a experiência comercial e a capacidade organizativa de alguns avicultores que contribuíram para a estruturação de uma cadeia produtiva altamente verticalizada.

Por sua vez, tomando como referência o conceito marxista de processo de trabalho e que compreende o trabalho, os meios de produção e o produto, analisouse o processo de estruturação das atividades econômicas nas quais o município se destaca produtivamente. Nessa análise, foi considerada a relação do processo de estruturação das atividades econômicas com as transformações estruturais ocorridas tanto no país, quanto no estado. No âmbito local, considerou-se também condições materiais e imateriais que favoreceram o crescimento econômico.

Para analisar o processo de trabalho das principais atividades econômicas, o trabalho de campo consistiu na realização de entrevistas com roteiros estruturados (anexo) e semiestruturados. Por se tratar de uma pesquisa qualitativa, o número de entrevistas com roteiros estruturados foi definido em campo. Quando grande parte das perguntas recebia respostas similares, percebeu-se que a realidade já estava suficientemente representada para uma pesquisa qualitativa.

Com roteiros estruturados foram realizadas as seguintes entrevistas: produtores agrícolas (21 agricultores familiares e 2 não familiares), avicultores ( 3 de 
porte grande, 2 de pequeno porte e 1 de médio porte) e produtores orgânicos (8 agricultores familiares).

Com roteiros semiestruturados foram entrevistados informantes-chave, tais como: pastores da Igreja Luterana, presidente e ex-presidente da Coopeavi, secretário municipal de meio ambiente, comerciantes, presidente da CAF, gerente estadual de agricultura orgânica, representantes comerciais de insumos, secretário executivo da associação de avicultores, técnico agropecuário do Instituto Capixaba de Pesquisa e Extensão Rural; presidente de associação de produtores e ex-prefeito municipal.

Considerando o longo período de análise, que compreende o início da formação territorial de Santa Maria de Jetibá na segunda metade do século XIX até o crescimento econômico recente, a tese foi estruturada em quatro capítulos.

No primeiro, busca-se compreender o processo inicial de formação do território de Santa Maria de Jetibá no contexto da colônia imperial de Santa Leopoldina. Como nas colônias imperiais do Espírito Santo o imigrante teve acesso à terra na forma de pequenas propriedades, abordou-se as particularidades da política de imigração para o estado e o processo de estabelecimento dos imigrantes na colônia de Santa Leopoldina, ressaltando o território referente à Santa Maria de Jetibá.

O segundo capítulo aborda a decadência econômica de Santa Leopoldina e as principais transformações estruturais do Espírito Santo entre 1930 e 1980 . Busca se compreender como a decadência e as transformações mencionadas se manifestaram em Santa Maria de Jetibá. Ressalta-se que nesse período Santa Maria de Jetibá era apenas um distrito de Santa Leopoldina, que havia se tornado município.

O terceiro capítulo aborda a evolução do processo de trabalho da avicultura de postura a partir da década de 1960, articulado às transformações estruturais do estado. Também foi considerado em que medida a avicultura contribuiu para o surgimento e expansão de atividades econômicas do município. Buscou-se analisar o processo de estruturação da atividade e identificar as condicionantes que foram fundamentais para que o município se tornasse o segundo maior produtor de ovos do país. 
Por fim, no último capítulo aborda-se a produção agrícola e orgânica. Analisou-se o processo de trabalho e de ambas as atividades e identificou-se, da mesma forma que no capítulo anterior, as condicionantes que contribuíram para que o município viesse a ser o maior produtor de alimentos orgânicos e hortaliças do estado. 


\section{A FORMAÇÃO TERRITORIAL DE SANTA MARIA DE JETIBÁ NO ÂMBITO DA COLÔNIA DE SANTA LEOPOLDINA}

\subsection{Imigração europeia para o Espírito Santo e a pequena propriedade rural}

A partir de 1847, no âmbito da transição do trabalho compulsório para a mão de obra livre e da expansão da cafeicultura, foram fundadas colônias de imigrantes estrangeiros no Espírito Santo. A fundação dessas colônias fazia parte da política do governo imperial para atrair imigrantes estrangeiros para o país.

Nessa política, denomina-se colônia ao "conjunto dos lotes de uma área previamente estabelecida pelo governo, juntamente com um núcleo populacional mais denso (vila), servindo como sede administrativa e local onde se realizam os serviços religiosos, comércio e vida recreativa" (SEYFERTH, 1974, p.54). As colônias se diferenciavam da forma de ocupação espacial predominante no país, ou seja, o latifúndio escravista, e os lotes que as constituíam eram, na verdade, pequenas propriedades, conforme será abordado mais adiante. Além disso, a utilização do trabalho escravo era proibida nas colônias pelo governo imperial (CARNEIRO, 1948).

$\mathrm{Na}$ acepção de SACK (2013), podemos considerar essas colônias como territórios, pois se tratavam de áreas cujo acesso era controlado por indivíduos, no caso representantes do governo imperial, que estabeleciam regras para a ocupação das colônias como forma garantir o controle delas. Nessa perspectiva do controle, a territorialidade consiste na "tentativa, por indivíduo ou grupo, de afetar, influenciar, ou controlar pessoas, fenômenos e relações, ao delimitar e assegurar seu controle sobre certa área geográfica. Essa área será chamada de território" (SACK, 2013, p. 76).

Era assim que as colônias funcionavam, como territórios com limites imprecisos, mas de acesso controlado pelo governo imperial, que assegurava não só a propriedade da terra ao imigrante europeu, mas também outros incentivos. Uma colônia imperial era um território com tratamento diferenciado, com recursos financeiros específicos e com acesso controlado, que, de certa forma, acabava influenciando o comportamento dos imigrantes. 
Embora as colônias tenham se constituído em territórios controlados, é importante ressaltar que o espaço antecede o território. Antes das colônias se constituírem em territórios, houve uma apropriação da natureza que resultou na formação do espaço geográfico. A implementação da política do governo imperial no espaço geográfico da colônia, possibilitou a formação de um território, pois

\begin{abstract}
Sempre que houver homens em interação com um espaço, primeiramente transformando a natureza (espaço natural) através do trabalho, e depois criando continuamente valor ao modificar e retrabalhar o espaço social, estar-se á também diante de um território, e não só diante de um espaço econômico: é inconcebível que um espaço que tenha sido alvo de valorização pelo trabalho, possa deixar de estar territorializado por alguém (SOUZA, 2001, p.96).
\end{abstract}

Quando foram fundadas as colônias no Espírito Santo, sua ocupação espacial ainda era incipiente. Iniciada tardiamente, a ocupação da província começou a se efetivar somente a partir do final da primeira metade do século XIX, quando foi introduzida a cafeicultura no sul da Província. Nessa região, mais especificamente nos vales dos rios Itabapoana e Itapemirim, concentraram-se as maiores fazendas escravistas e, por muitos anos, a maior produção de café do Espírito Santo.

Logo após a emergência da cafeicultura no Espírito Santo, inicia-se a chegada do imigrante europeu. Distantes das fazendas escravistas, as colônias para receberem esses imigrantes foram localizadas na região central do Espírito Santo, onde predominou a pequena propriedade e o trabalho familiar. Ambas as regiões, a central e a sul, eram produtoras de café, mas se diferenciavam tanto nas relações de trabalho, quanto na dimensão física das propriedades.

No entanto, a imigração europeia para o Espírito Santo assume características singulares em relação à forma como foi predominantemente conduzida no país. Primeiramente, a maioria dos imigrantes europeus, também denominados colonos, não substituiu o trabalho escravo nas fazendas de café e teve acesso à terra, na forma de pequenas propriedades. A forma como a transição das relações de trabalho foi conduzida, favoreceu a expansão da pequena propriedade rural baseada no trabalho familiar em detrimento da grande propriedade escravista.

Até a Abolição da Escravidão os imigrantes europeus que desembarcaram no Espírito Santo se dirigiram para as colônias existentes, onde receberam um pequeno lote de terra. Somente após a abolição é que há uma mudança no destino 
do imigrante, quando a maioria se dirige para as fazendas para trabalhar como meeiros. Mesmo como meeiros, a maioria desses imigrantes também teve acesso a propriedade da terra.

São, portanto, dois momentos distintos em relação ao destino do imigrante: antes da Abolição, as colônias e após, as fazendas. No entanto, a maioria dos imigrantes se fixou nas colônias e estas não tiveram como função atender aos interesses da grande propriedade do Espírito Santo, conforme será abordado adiante.

Em segundo lugar, no Espírito Santo a imigração foi promovida pela iniciativa pública (quadro 1). Primeiramente pelo governo imperial e, posteriormente na República pelo governo estadual. As poucas experiências conduzidas por particulares não foram muito bem sucedidas, por exemplo: a colônia de Rio Novo ${ }^{1}$ foi encampada pelo governo imperial devido ao seu fracasso e o núcleo de Santa Leocádia teve sua população quase dizimada pela febre amarela, pois o local estava infestado pelo mosquito transmissor da doença. Na república foram criados mais seis núcleos coloniais ${ }^{2}$ de imigrantes europeus no Espírito Santo (PACHECO, 1978) e embora tenha havido experiências conduzidas por particulares, isso foi exceção.

\begin{tabular}{|c|c|c|c|}
\hline \multicolumn{4}{|c|}{$\begin{array}{l}\text { Quadro } 1 \\
\text { Espírito Santo: colônias e núcleos coloniais de imigrantes } \\
\text { europeus criados durante o Império (2einado/1840-1889) }\end{array}$} \\
\hline \multicolumn{2}{|c|}{ Colônias e Núcleos } & Fundação & Natureza \\
\hline \multirow{4}{*}{ 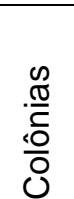 } & Santa Izabel & 1847 & Imperial \\
\hline & Rio Novo & 1854 & particular/imperial \\
\hline & Santa Leopoldina & 1856 & Imperial \\
\hline & Castelo & 1880 & Imperial \\
\hline \multirow{5}{*}{$\frac{\mathscr{c}}{0}$} & Fransilvânia & não executado & Particular \\
\hline & Piúma & 1865 & Particular \\
\hline & Timbuí & 1874 & Imperial \\
\hline & Santa Cruz & 1877 & Imperial \\
\hline & Santa Leocádia & 1887 & Particular \\
\hline
\end{tabular}

Fonte: PACHECO (1978) e ROCHA (2000).

Elaboração: BERGAMIN, M, C.

\footnotetext{
1 A colônia de Rio Novo foi criada em 1855 pelo Major Caetano Dias da Silva, um ex-traficante de escravos. A colônia foi um fracasso e a maioria dos imigrantes que nela se instalaram, retiraram-se. Em 1861 foi encampada pelo governo imperial e tornou-se uma grande colônia.

${ }^{2}$ As colônias possuíam uma estrutura mais complexa (diretor, médico, instituição religiosa e escola) e um número maior de imigrantes. Já os núcleos coloniais eram menores (área e número de imigrantes) e alguns surgiram como expansão de colônias e, portanto, estavam subordinados a elas. Outros núcleos, após a Abolição, foram criados para atender as necessidades de mão de obra da grande propriedade.
} 
Enquanto no Espírito Santo a participação da iniciativa pública na condução da imigração europeia foi preponderante, no Brasil verifica-se uma realidade inversa, uma vez que entre 1850 e 1889, $78.8 \%$ das colônias e núcleos foram criados por iniciativas particulares (IOTTI, 2010).

Outro aspecto é que no Espírito Santo, a produção principal das colônias sempre foi o café, cultivado não para o consumo, mas prioritariamente para o mercado. Da mesma forma que o fazendeiro escravista, no Espírito Santo a pequena propriedade familiar do imigrante também produzia uma cultura de exportação. Nos escassos núcleos urbanos do Espírito Santo e com número muito reduzido de habitantes, não havia um mercado consumidor com capacidade para absorver a produção de gêneros alimentícios das colônias. Naquele momento o café colocavase como melhor alternativa econômica.

Nesse contexto de transição das relações de trabalho, questiona-se as razões das particularidades da política imigratória para o Espírito Santo. Uma delas se deve ao fato da incipiente ocupação espacial do Espírito Santo que em 1856, após mais de três séculos de colonização, possuía somente 49.092 habitantes (SALETTO, 1996). Além disso, o Espírito Santo possuía poucos e esparsos núcleos urbanos localizados no litoral e desarticulados entre si (CAMPOS JUNIOR, 1996). Com esse padrão de ocupação espacial,

\footnotetext{
"O Espírito Santo, província ainda desabitada, com enormes extensões de terras devolutas, oferecia excelentes condições para a instalação de núcleos coloniais. Seus presidentes não cansavam de lamentar sua pobreza e atraso [...] e clamavam por braços, indispensáveis ao desenvolvimento. As reivindicações não eram de mão de obra para as fazendas, mas sim de habitantes para colonizar" (SALETTO, 1996b, p. 50).
}

Dessa forma, o Espírito Santo foi contemplado pela política do governo imperial de criação de colônias de pequenas propriedades de imigrantes europeus. A pequena propriedade tinha como função ocupar e valorizar as terras, produzir para abastecer o latifúndio e as cidades, bem como estabelecer uma classe social intermediária entre os latifundiários e os escravos (IOTTI, 2001; PETRONE, 1982).

A pequena propriedade do imigrante desempenhou papel fundamental na ocupação espacial do Espírito Santo e também contribuiu para a valorização fundiária. Embora a pequena propriedade do imigrante não tenha abastecido o latifúndio, a partir da sua expansão formou-se uma importante classe de 
trabalhadores livres, constituída por agricultores familiares, em uma província/país escravista.

Como havia uma grande disponibilidade de terras, majoritariamente devolutas, em uma província pouco habitada, a entrada do imigrante, mesmo com acesso a propriedade da terra nas colônias, foi bem aceita e até estimulada pelos fazendeiros escravistas do Espírito Santo. O fazendeiro não se sentia ameaçado e acreditava que 0 imigrante poderia contribuir para alavancar 0 parco desenvolvimento da província. Nesse momento, os interesses da classe constituída pelos fazendeiros não eram conflitantes com a política imigratória do governo imperial. Dessa forma, "no Espírito Santo, não se registra durante todo o tempo de vigência do trabalho escravo, nenhuma contestação da grande lavoura ao estabelecimento de imigrantes nas terras devolutas demarcadas pelo Governo Imperial" (ROCHA, 2000, p. 54).

O fazendeiro do Espírito Santo manteve-se alheio às mudanças nas relações de trabalho em curso no país e somente manifestou-se contrário à criação de colônias de imigrantes às vésperas da abolição da escravidão. A manifestação tardia provocou a falência de várias fazendas, sobretudo no vale do Itapemirim, pela forte escassez de mão de obra que se estendeu ao longo dos primeiros anos pósabolição.

Diferentemente dos grandes proprietários do Espírito Santo, o fazendeiro paulista mostrou-se contrário à política imigratória do governo imperial. Tratava-se de uma política que se opunha aos interesses dos fazendeiros e, dessa forma,

\begin{abstract}
A oposição entre a política conduzida pelo poder central e os interesses dos fazendeiros paulistas manifestou-se várias vezes. O Governo do Império, visava sobretudo, a estimular a imigração de povoamento, o tipo de colonização levada a efeito nos núcleos coloniais, nos quais o imigrante tinha acesso à propriedade [...]. Entretanto, todas as vezes em que os fazendeiros do Oeste Paulista conseguiram fazer prevalecer seus interesses, dominou a política que visava a fornecer braços para as lavouras (COSTA, 1966. p. 69).
\end{abstract}

Na mesma perspectiva, ao analisar o posicionamento do fazendeiro de café de São Paulo em relação ao estabelecimento de colônias de imigrantes, Carneiro (1948) afirma que, 
não. Essa lavoura é que lhes permitia acumular, permitia ao país as divisas que ele necessitava e que pagava o funcionalismo, a Corte, o Exército e a Marinha. Ela, e não a pequena propriedade é que era expressiva no processo de acumulação capitalista (p. 1022).

Apesar da contestação dos fazendeiros paulistas, dezenas de núcleos coloniais foram estabelecidos em São Paulo, mas sempre a margem da grande propriedade cafeicultora. Esses núcleos desempenharam várias funções e daí o seu caráter ambivalente, uma vez que

sempre foram apresentados de modo que a sua existência de alguma forma se ligasse aos interesses da cafeicultura: como abastecedores das regiões carentes de gêneros, como foco de atração de imigrantes ou como meio para a criação de um semiproletariado para a grande lavoura" (MARTINS, 1973, p. 63).

No Espírito Santo, até a Abolição, as colônias e núcleos também tiveram um caráter ambivalente, mas de outra natureza: primeiramente ocupar as terras de uma província muito pouco habitada e, posteriormente, contribuir para a atração de imigrantes que iriam também atender a demanda de mão de obra da grande propriedade cafeicultora de São Paulo.

Identifica-se aí a outra razão, a qual se refere ao uso do Espírito Santo, pelo governo imperial, como propaganda para atrair o imigrante europeu para o país, uma vez que nessa província/estado e também no sul do país, o acesso a terra foi assegurado. Ao se criar esses as colônias, passava-se a imagem de que o país estava comprometido com o imigrante, assegurando-Ihe o acesso a terra. Essa postura do governo atraía o imigrante para o país, que em sua maioria foi levado para São Paulo, onde substituiu o escravo nas lavouras de café (CAMPOS JUNIOR, 1996 e ROCHA, 2000).

No Espírito Santo, as colônias de imigrantes europeus foram fundadas a partir de 1847, ou seja, num período muito próximo da aprovação da Lei de Terras e do fim do tráfico de escravos. Apesar das mudanças proporcionadas por essas leis, o governo imperial, o principal agente condutor do processo de imigração estrangeira para o Espírito Santo, assegurou ao imigrante o acesso à propriedade da terra.

A postura do governo imperial reforça a ideia da utilização do Espírito Santo como propaganda. Havia sim o interesse do governo imperial em ocupar províncias fracamente habitadas. No entanto, essa política do governo imperial também atendia 
aos interesses da classe de fazendeiros paulistas, uma vez que era um fator de atração de imigrantes para o país.

Em 1848 foi aprovada a Lei no 514 que concedia às províncias, por intermédio do governo imperial, terras devolutas para serem usadas para o estabelecimento de colônias provinciais. Na medida em que as províncias ganharam autonomia para conduzir a colonização, os projetos de desenvolvimento provinciais tornaram-se mais relevantes que os nacionais. As províncias que tinham recursos financeiros para conduzir o processo de imigração, faziam-no de acordo com suas necessidades e interesses econômicos.

Essa mudança nos rumos da política imperial de núcleos coloniais ocorreu para atender, sobretudo, as pressões e os interesses da classe política formada pelos fazendeiros paulista. Dessa forma, a política imperial deixou de ser um projeto nacional e passou a ter um caráter regional (IOTTI, 2001). Constata-se que,

\footnotetext{
Se no começo da política imigracionista o Brasil visava apenas a chamar o imigrante para instalá-lo em pequenas propriedades, já na década de 1840 surgiu uma cisão: os cafeicultores paulistas pretendiam aproveitar o imigrante para solucionar os seus problemas de mão de obra, já que se prenunciava a extinção do tráfico de escravos (PETRONE, 1992, p. 20).
}

Os interesses iniciais da política migratória do governo imperial foram suplantados pelos interesses, sobretudo, dos fazendeiros paulistas. Nesse momento, a imigração europeia para o Espírito Santo torna-se uma resposta à crise, mas a crise estrutural da produção cafeeira com manifestação verificada primeiro em São Paulo, sobretudo.

Segundo Martins (1973), a imigração estrangeira para o Brasil foi uma resposta a uma crise inerente ao padrão de realização do capitalismo no país. "As duas expressões da instauração dessa crise foram a universalização jurídica da propriedade privada da terra com pela Lei de Terras de 1850 e a implantação completa do trabalho livre pela Lei Áurea em 1888" (MARTINS, 1973, p. 14). Para se constituir o mercado de trabalho limitou-se o acesso a terra tornando-a propriedade privada e acessível somente por meio da compra e também se separou a pessoa do trabalhador da força de trabalho com o fim do trabalho cativo.

Enquanto uma resposta à crise, a imigração europeia no Espírito Santo atendeu prioritariamente aos interesses nacionais em detrimento dos provinciais, 
uma vez que, até a Abolição, o destino do imigrante não foi a fazenda. Ressalta-se também que o acesso a terra foi possibilitado ao imigrante e, dessa forma, não houve a separação da força de trabalho da pessoa do trabalhador. Tais aspectos da imigração estrangeira para o Espírito Santo estão relacionados tanto a política imigratória do governo imperial, quanto a influência política dos grandes proprietários de terra paulistas.

Em que pesem os interesses paulistas, não se pode deixar de considerar que a política de imigração via núcleos coloniais do governo imperial atingiu seus objetivos no Espírito Santo. Foi a partir dessa política que a ocupação espacial do Espírito Santo se tornou mais célere.

\subsection{As colônias de imigrantes e a Abolição da Escravidão}

Iniciada no Espírito Santo a partir de 1847, a política de imigração europeia foi subvencionada pelo Governo imperial até a Proclamação da República. Para tornar a imigração para o Brasil mais atrativa, o governo imperial aprovou o Decreto n.. 3784 de 1867, que regulamentava as colônias sob sua jurisdição e oferecia os seguintes incentivos ao imigrante: hospedagem em um edifício na colônia, um lote de terra variando entre 15 e 60ha aproximadamente; instrumentos de trabalho e sementes para as primeiras plantações de culturas alimentares; auxílio financeiro para o estabelecimento do imigrante e de sua família. Além disso, quando houvesse necessidade de mão de obra na construção da infraestrutura da colônia, a preferência era do imigrante.

Todos esses incentivos eram subvencionados pelo governo imperial. Acerca das despesas empreendidas com cada família, o governo imperial concedia ao imigrante o prazo de cinco anos para pagá-las, contados após dois anos da chegada ao lote colonial. Além dos incentivos mencionados, em determinados períodos as despesas com as passagens foram gratuitas (PACHECO, 1987).

No entanto, nem todos os incentivos previstos nos contratos foram sempre cumpridos de imediato pelo governo imperial. A província não estava estruturada para receber essas levas de imigrantes. O processo de instalação do imigrante na colônia era moroso e os prazos para cada etapa não eram cumpridos com rigor. 
Iniciava-se com a demora na transferência dos imigrantes de Vitória para a colônia. Após a chegada do imigrante na colônia e a instalação nos precários barracões, a demarcação dos lotes, o pagamento tanto dos recursos para os imigrantes se estabelecerem inicialmente quanto dos seus salários, ocorriam com muitos atrasos. A demarcação dos lotes era imprecisa e ainda ocorria em áreas inférteis, os edifícios para receberem os imigrantes nas colônias, também chamados de "barracões", eram inadequados e insuficientes. O imigrante chegava ao Espírito Santo, mas as condições para recebê-lo, conforme previsto nos contratos, nem sempre estavam estruturadas.

Além desses exemplos, o imigrante também enfrentou muitas dificuldades para desenvolver as atividades agrícolas em um país tropical, com características naturais bem diferentes da Europa. Era comum o reconhecimento dos imigrantes europeus como

\footnotetext{
detentores de conhecimentos técnicos superiores aos dos brasileiros, quando, na realidade, a agricultura que praticavam aqui era inteiramente diferente da que conheciam na Europa, inclusive quanto às espécies cultivadas. Para a agricultura extensiva do café em clima tropical, eles estavam totalmente despreparados (SALETTO, 1996a, p. 145).
}

Antes mesmo da aprovação do decreto que regulamentava as colônias, o imigrante europeu no Espírito Santo já era contemplado por incentivos semelhantes aos previstos no regulamento em questão. Apesar disso a imigração permaneceu lenta e só veio a tornar-se mais expressiva, para os padrões do Espírito Santo, na década de 1870, quando se registram as primeiras entradas de imigrantes italianos. O decreto tinha como objetivo atrair mais imigrantes para o país e após sua aprovação houve aumento considerável da imigração para o Espírito Santo, conforme tabela 1.

No entanto, na década de 1880, verifica-se uma queda vertiginosa na imigração para o Espírito Santo. Ocorre que "em 1879 o Governo Imperial retirou dos núcleos coloniais todos os favores que lhes eram assegurados pelo decreto ํㅡ 3.784 , de 19 de janeiro de 1867, havendo inclusive suspendido o pagamento de passagens aos imigrantes que se destinavam ao Brasil" (ROCHA, 2000, p.76). Todos os incentivos concedidos aos imigrantes pelo governo imperial foram suprimidos, uma vez que 
Passaram as autoridades imperiais a legislar em proveito da grande lavoura, substituindo a política de criação e incentivo aos núcleos coloniais de pequenos proprietários por uma política mais agressiva e direta que visava estabelecer o estrangeiro nas grandes propriedades. E certamente não foi por acaso que essa mudança se concretizou quando ocupava a Pasta do Ministério da Agricultura um dos mais influentes fazendeiros do oeste paulista, Antonio da Silva Prado (ROCHA, 2000, p. 99).

Tabela 1

ESPÍRITO SANTO: imigração estrangeira (1847 - 1900)

\begin{tabular}{cccccccc}
\hline Ano & $\begin{array}{c}\mathbf{N}^{\circ} \text { de } \\
\text { imigrantes }\end{array}$ & Ano & $\begin{array}{c}\mathbf{N}^{\circ} \text { de } \\
\text { imigrantes }\end{array}$ & Ano & $\begin{array}{c}\mathbf{N}^{\circ} \text { de } \\
\text { imigrantes }\end{array}$ & Ano & $\begin{array}{c}\mathbf{N}^{\circ} \text { de } \\
\text { imigrantes }\end{array}$ \\
\hline $\mathbf{1 8 4 7}$ & 51 & $\mathbf{1 8 6 1}$ & 129 & $\mathbf{1 8 7 5}$ & 1.500 & $\mathbf{1 8 8 9}$ & 3.068 \\
$\mathbf{1 8 4 8}$ & 0 & $\mathbf{1 8 6 2}$ & 85 & $\mathbf{1 8 7 6}$ & 3.838 & $\mathbf{1 8 9 0}$ & 560 \\
$\mathbf{1 8 4 9}$ & 0 & $\mathbf{1 8 6 3}$ & 44 & $\mathbf{1 8 7 7}$ & 2.374 & $\mathbf{1 8 9 1}$ & 5.171 \\
$\mathbf{1 8 5 0}$ & 0 & $\mathbf{1 8 6 4}$ & 1 & $\mathbf{1 8 7 8}$ & 1.016 & $\mathbf{1 8 9 2}$ & 1.323 \\
$\mathbf{1 8 5 1}$ & 33 & $\mathbf{1 8 6 5}$ & 6 & $\mathbf{1 8 7 9}$ & 435 & $\mathbf{1 8 9 3}$ & 3.566 \\
$\mathbf{1 8 5 2}$ & 0 & $\mathbf{1 8 6 6}$ & 3 & $\mathbf{1 8 8 0}$ & 1.193 & $\mathbf{1 8 9 4}$ & 6.356 \\
$\mathbf{1 8 5 3}$ & 0 & $\mathbf{1 8 6 7}$ & 48 & $\mathbf{1 8 8 1}$ & 86 & $\mathbf{1 8 9 5}$ & 5.960 \\
$\mathbf{1 8 5 4}$ & 0 & $\mathbf{1 8 6 8}$ & 28 & $\mathbf{1 8 8 2}$ & 123 & $\mathbf{1 8 9 6}$ & 3.319 \\
$\mathbf{1 8 5 5}$ & 38 & $\mathbf{1 8 6 9}$ & 407 & $\mathbf{1 8 8 3}$ & 117 & $\mathbf{1 8 9 7}$ & 480 \\
$\mathbf{1 8 5 6}$ & 210 & $\mathbf{1 8 7 0}$ & 1 & $\mathbf{1 8 8 4}$ & 63 & $\mathbf{1 8 9 8}$ & 215 \\
$\mathbf{1 8 5 7}$ & 238 & $\mathbf{1 8 7 1}$ & 1 & $\mathbf{1 8 8 5}$ & 252 & $\mathbf{1 8 9 9}$ & 29 \\
$\mathbf{1 8 5 8}$ & 474 & $\mathbf{1 8 7 2}$ & 584 & $\mathbf{1 8 8 6}$ & 259 & $\mathbf{1 9 0 0}$ & 148 \\
$\mathbf{1 8 5 9}$ & 972 & $\mathbf{1 8 7 3}$ & 1.568 & $\mathbf{1 8 8 7}$ & 517 & & \\
$\mathbf{1 8 6 0}$ & 283 & $\mathbf{1 8 7 4}$ & 394 & $\mathbf{1 8 8 8}$ & 4.355 & & \\
\hline
\end{tabular}

TOTAL: $\mathbf{5 1 . 9 2 1}$

Fonte: Arquivo Público do Espírito Santo, 2013.

Elaboração: BERGAMIN, M. C.

A imigração para as colônias perdeu os incentivos, mas em contrapartida as fazendas foram beneficiadas pelo governo imperial. As passagens dos imigrantes que se dirigissem para as fazendas seriam integralmente pagas pelo governo imperial, mas somente após a instalação do imigrante na fazenda. Primeiro o fazendeiro custeava as passagens e depois solicitava o ressarcimento dos recursos investidos.

Tratava-se de um processo extremamente burocrático e que demandava a apresentação de vários documentos comprovatórios da imigração, emitidos por instituições públicas do país. Ao analisar tais exigências, Rocha afirma que "Essas disposições, bem se vê, não eram de modo a favorecer os proprietários menos dotados de recursos" (ROCHA, 2000, p. 100). Conclui-se que os principais beneficiados foram os grandes fazendeiros paulistas. 
Essa mudança nos rumos da imigração foi adotada devido às pressões políticas dos fazendeiros paulistas para atrair imigrantes para suas fazendas de café. Detentores de volumosos recursos financeiros, os fazendeiros paulistas sustentaram facilmente a entrada de imigrantes em suas fazendas. Na década de 1880 a imigração estrangeira para São Paulo cresceu vertiginosamente, ultrapassando mais de 300 mil imigrantes (BASSANEZI, SCOTT, BACELLAR, 2008).

As mudanças na política imigratória manifestaram-se de forma inversa no Espírito Santo. Houve uma redução drástica na entrada de imigrantes e, até a Abolição, a maioria deles fixou-se nos núcleos e nas ex-colônias ${ }^{3}$. Apesar do governo imperial ter passado a subvencionar as passagens dos imigrantes que se destinassem as fazendas, o que se verifica no Espírito Santo é que até próximo a Abolição o fazendeiro não empregou a mão de obra do imigrante. "Os fazendeiros não quiseram ou não puderam importar imigrantes para substituir os escravos" (SALETTO, 1996a, p. 132). Dessa forma,

\begin{abstract}
Somente às vésperas da Abolição, quando o Governo assumiu o encargo de fornecer gratuitamente imigrantes para as fazendas e o sistema escravista desmoronava, os fazendeiros do Itapemirim começaram a introduzi-los em suas fazendas e mesmo assim, em número muito reduzido. (SALETTO, 1996b, p. 84).
\end{abstract}

Localizadas em sua maioria no sul do Espírito Santo, as fazendas escravistas capixabas enfrentaram sérios problemas com a falta de mão de obra após a Abolição. Sobre os impactos da Abolição nas fazendas capixabas, afirma que "Os fazendeiros iniciaram a colheita do café. Por toda parte fazendas foram abandonadas pelos escravos, safras perdidas. Logo começou a procura de imigrantes enviados pelo governo central" (SALETTO, 1986a, p. 92). No entanto, no ano em que ocorre a Abolição, o imigrante ainda preferiu os núcleos coloniais. Dos mais de 4.000 imigrantes que entraram em 1888, apenas 831 se fixaram nas fazendas do sul do Espírito Santo (SALETTO, 1986a).

Apesar disso, a Abolição vai redefinir o destino do imigrante no Espírito Santo. A partir da mudança nas relações de trabalho, os imigrantes passam a se

\footnotetext{
${ }^{3}$ Em 1882 foi emancipada a última colônia do Espírito Santo. Na década de 1880 houve queda drástica na imigração para a província e até às vésperas da Abolição, esses imigrantes não se fixaram nas fazendas. Como havia poucos núcleos coloniais, é provável que parte desses imigrantes tenha se fixado nas ex-colônias.
} 
fixar também nas fazendas para substituir a mão de obra escrava. No entanto, a imigração para as fazendas não foi suficiente para substituir o trabalho escravo.

Conforme pode ser observado na tabela 2, nos anos iniciais pós-extinção do trabalho escravo, há uma oscilação na entrada de imigrantes, com destaque para uma queda brusca nos anos 1890 e 1892, quando se registra menos de 1000 imigrantes. Considerando que em 1884 havia aproximadamente 20 mil escravos nos Espírito Santo (ALMADA, 1981), constata-se que mesmo se todos os imigrantes fossem para as fazendas, não seriam suficientes para suprir a demanda de mão de obra da grande propriedade.

Acrescente-se também que o fim da escravidão coincide com a expansão da cafeicultura, ou seja, no momento em que havia um aumento da demanda de mão de obra, esta se reduz drasticamente. Consequentemente muitas fazendas escravistas, localizadas predominantemente no sul do Espírito Santo, por não suportarem a carência de mão de obra faliram e foram fragmentadas em pequenas propriedades rurais, vendidas principalmente para os imigrantes. Saletto (1996b) lamenta a falta de estatísticas confiáveis sobre o processo de fragmentação da grande propriedade do sul do Espírito Santo, mas afirma que no sul capixaba, "ele atingiu a maior parte do Vale do Itapemirim, Castelo e Alto-Castelo, e teve participação intensa dos imigrantes como compradores" (SALETTO 1996b, p. 108).

Diante da crise de mão de obra enfrentada pelo grande proprietário de terra, a imigração estrangeira toma novos rumos. Em 1892, após quatro anos da Abolição, o governador do estado, Moniz Freire, criou um programa de imigração estrangeira. Por meio da lei estadual no 4 de 1892, a imigração estrangeira para o Espírito Santo foi regulamentada e subvencionada pelo estado. Foram criados novos núcleos de colonização e uma série de incentivos era oferecida ao imigrante, em padrões semelhantes aos proporcionados durante a vigência do governo imperial.

O imigrante poderia escolher entre a fazenda e o núcleo, mas havia uma certa pressão para que optasse pela fazenda, onde trabalharia como parceiro. $O$ destino principal da imigração deixou de ser os núcleos de colonização e passou a ser as fazendas, de forma que, entre 1892 e 1896, dos 13.244 imigrantes que entraram no Espírito Santo, 6.924 fixaram-se nas fazendas (ROCHA, 2000). 
$\mathrm{Na}$ grande propriedade entre o imigrante e o fazendeiro estabeleceu-se a parceria, uma relação de trabalho não mediada pelo dinheiro. Pelo uso da terra o parceiro, representado pelo imigrante, pagava uma renda em produto ao fazendeiro, proprietário fundiário e capitalista. No entanto, como a terra não era escassa e havia a opção pela propriedade fundiária em um núcleo colonial, o que atraía o imigrante para a fazenda era a infraestrutura construída e o cafezal em produção. Dessa forma, o fazendeiro só obtinha força de trabalho por meio do seu capital. Nesse sentido,

\begin{abstract}
A terra não era o elemento fundamental, no sentido de que não era a sua propriedade por si só, que permitia ao fazendeiro submeter o colono à extração do sobretrabalho. Não monopolizando a terra e não podendo, portanto, vedar-Ihe o acesso ao imigrante pode-se dizer que a sujeição do colono à extração da mais valia era obtida através do capital. Capital que, no entanto, não tem uma existência independente, pois pressupõe, como condição básica, a propriedade da terra (SALETTO, 1996b, p. 133).
\end{abstract}

Considerando a carência de mão de obra, o fazendeiro teve que oferecer condições de trabalho mais vantajosas ao imigrante. Na parceria era assegurada ao imigrante uma casa para morar, terra para plantar e um cafezal em produção. Somente a cultura do café era dividida, cabendo $50 \%$ da produção para cada uma das partes. O imigrante pagava uma renda em produto somente em relação à produção de café. Portanto,

\begin{abstract}
"por causa da falta de mão de obra os fazendeiros foram "coagidos" a oferecer a meação em condições muito mais favoráveis ao trabalhador do que nas outras regiões. O parceiro capixaba dispunha de toda a produção de cereais, enquanto os fluminenses e os mineiros tinham que pagar a terça sobre ela; essa produção se fazia em cafezais novos (sobretudo nos primeiros tempos após a Abolição), portanto com maior rendimento e com possibilidade de praticar cultivo intercalar, e, finalmente, enquanto os parceiros de várias regiões do país eram obrigados a trabalhar como diaristas ou gratuitamente, os do Espírito Santo não tinham essa obrigação e recusavam trabalho a salário" (SALETTO, 1996b, p. 130-131).
\end{abstract}

Apesar das condições vantajosas da parceria, para o imigrante essa era uma situação transitória até se tornar proprietário. Ao optar pela fazenda, o imigrante "recebia imediatamente uma casa, um cafezal, terreno pra plantar e um adiantamento sobre o café que garantia a manutenção da família até a colheita" (SALETTO, 1996b, p.95-96). O retorno financeiro era menor, mas bem mais rápido do que se fosse para o núcleo. 
Indo para o núcleo, o imigrante receberia um lote em mata e tudo teria que ser construído. Considerando que o imigrante dispunha de poucos recursos financeiros, a parceira possibilitava formar uma poupança e amenizar os inconvenientes da instalação futura em um núcleo ou uma propriedade adquirida do estado. Fato que realmente se concretizou, pois a maioria dos imigrantes tornou-se proprietária de terras. Para a grande propriedade, a parceria solucionava temporariamente o problema da mão de obra.

Diferentemente do que ocorreu nas regiões cafeicultoras do país, no Espírito Santo a pequena propriedade suplantou a grande. A forma como a imigração e a transição do trabalho compulsório para a mão de obra livre foi conduzida, expandiu a pequena propriedade e a tornou dominante no Espírito Santo. A efetiva ocupação espacial capixaba foi proporcionada pela pequena propriedade rural baseada no trabalho familiar e pela cafeicultura cultivada sem recursos técnicos. Esses aspectos não podem ser considerados um mero detalhe, mas uma condição estruturante da formação espacial capixaba.

\subsection{A colônia imperial de Santa Leopoldina}

A origem de Santa Leopoldina, uma das maiores colônias do país, remete aos anos de 1856, quando a província do Espírito Santo sugeriu ao império algumas áreas adequadas para a instalação de projetos de colonização. Considerando as indicações da província, em 27 de fevereiro de 1856, por meio do aviso ㄲo 10, o governo imperial determinou que o presidente da província do Espírito Santo que: medisse e demarcasse um terreno de quatro léguas quadradas, para o estabelecimento de uma colônia agrícola no vale do rio Santa Maria, entre as cachoeiras Grande e de José Cláudio; demarcasse nesse terreno lotes coloniais de 62.500 braças quadradas (aproximadamente 30 ha) e uma área para a sede da colônia, onde seria construído o barracão, a igreja, a casa do diretor, entre outros (IOTTI, 2001).

Como parte da política de colonização do governo imperial, em 1857 foi fundada a colônia de Santa Maria, posteriormente denominada Santa Leopoldina (Figura 1). A colônia foi localizada em Vitória, capital do Espírito Santo, que na época era um município de grande extensão territorial e definido por limites políticos 


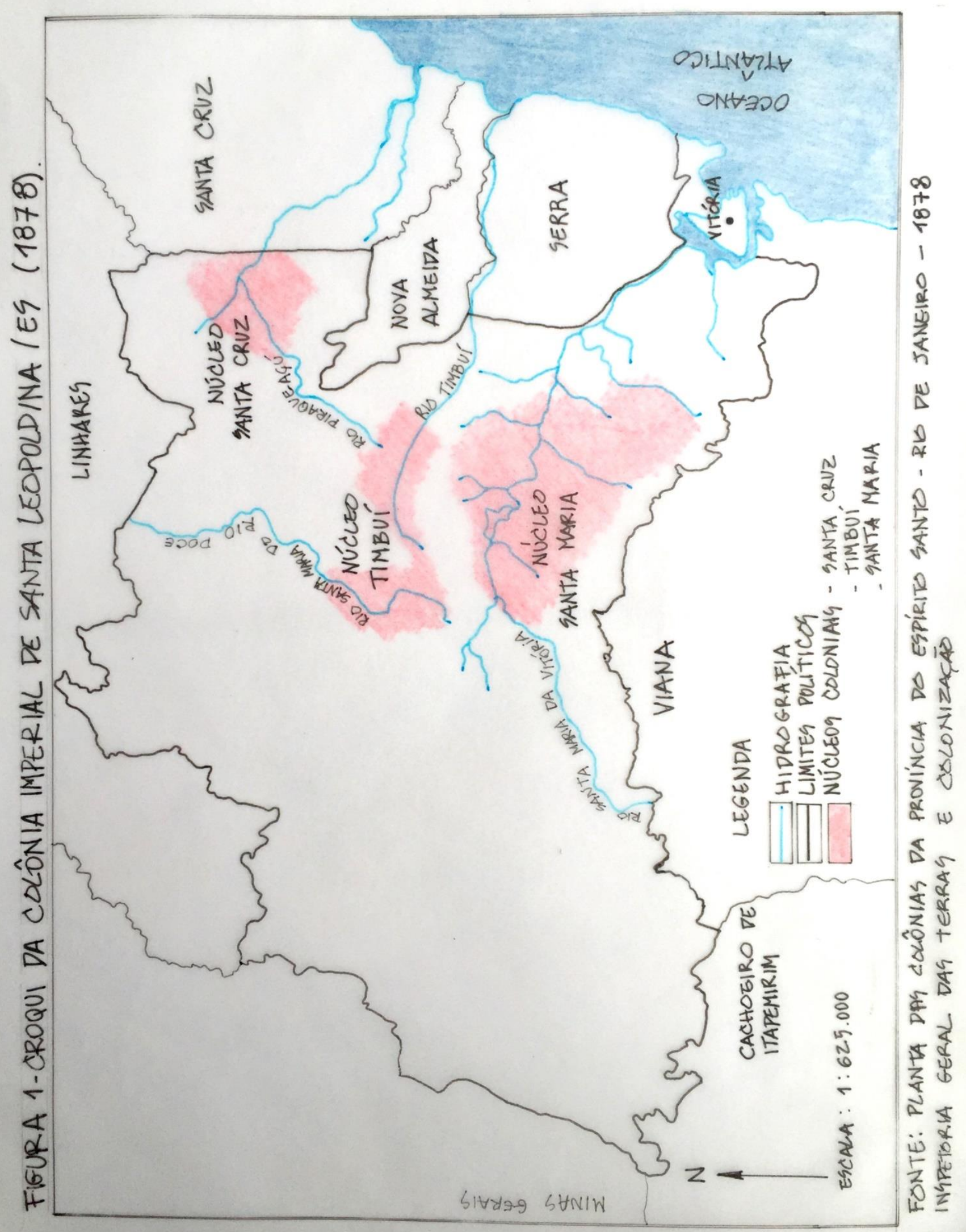


bastante diferentes dos atuais. Distante aproximadamente a $50 \mathrm{~km}$ a noroeste da sede da capital, a colônia de Santa Leopoldina apresentava altitude bastante variável, com áreas próximas do nível do mar e outras acima de 1000 m, no entanto, o relevo acidentado era predominante. A colônia encontrava-se totalmente encoberta pela vegetação de Mata Atlântica em estágio primitivo de conservação e sem comunicação com qualquer região do Espírito Santo, a exceção da capital, via rio Santa Maria da Vitória.

A demarcação dos lotes, como era comum nas colônias brasileiras, era feita a partir do fundo dos vales. Eram lotes estreitos e compridos. O relevo acidentado da colônia de Santa Leopoldina favorecia essa forma de demarcação e o fundo dos vales representava as linhas coloniais (PETRONE, 2004). "Os lotes foram demarcados ao longo das "linhas", de modo a se apresentarem com testada para o curso d'água e com fundos para as cumeeiras dos interflúvios. Dessa forma, toda a penetração se efetuou por intermédio dos fundos dos vales" (PETRONE, 2004, p. 28).

Como uma colônia imperial, desde a sua fundação os imigrantes tiveram acesso aos incentivos, como um lote, passagens, auxílios financeiros e instrumentos de trabalho, os quais, posteriormente foram regulamentados pelo governo imperial para tornar mais atrativa a imigração para o país. Apesar de previstos e posteriormente regulamentados pelo governo imperial, os incentivos eram concedidos morosamente aos imigrantes.

Dessa forma, os anos iniciais da colônia foram os mais difíceis e muitos imigrantes encontravam-se em péssimas condições de vida. Os salários e os recursos recebidos pelos imigrantes eram insuficientes para assegurar uma alimentação adequada. Havia também dificuldades de adaptação aos novos hábitos alimentares e de desenvolver os cultivos em terras tropicais. Para verificar a situação dos suíços, Tschudi (2004), em visita à colônia em 1860, três anos após a sua fundação, identifica que

Um número bastante considerável de colonos está doente ou debilitado, principalmente entre os suíços, os holandeses e os prussianos. Fica-se chocado com a visão de criaturas pálidas, inchadas, enfraquecidas e abatidas. A causa não está no clima, mas sim numa alimentação precária. Um grande número de colonos está reduzido a uma dieta quase exclusivamente de farinha de mandioca, cozida na água ou na forma de beiju (p.37 e 39). 
Além dos incentivos concedidos diretamente ao imigrante, uma colônia imperial também recebia recursos financeiros específicos para construir a infraestrutura necessária ao seu bom desempenho e oferecer alguns serviços aos imigrantes, como atendimento médico e educação. No entanto, a colônia passou a dispor de um médico somente a partir de 1873 (GROSSELLI, 2008). Quem construía a infraestrutura da colônia era o próprio imigrante, mas era remunerado por esse trabalho. Uma colônia imperial era uma área que se diferenciava pelo tratamento especial que recebia do governo imperial.

Como exemplo, os recursos do governo imperial, tão importantes para o desenvolvimento da colônia, eram repassados com atraso para a província. Consequentemente, o repasse do recurso para a colônia atrasava também. Diante dessa situação, a colônia ficava sem recursos para assegurar que os pagamentos aos imigrantes fossem efetuados dentro dos prazos previstos.

Em diversos documentos enviados por diretores da colônia aos presidentes da província, o atraso no pagamento aos imigrantes pelos serviços prestados à colônia era uma das reclamações mais recorrentes. Atrasos esses que chegavam a três meses. É importante salientar que o imigrante entrava no país com recursos financeiros limitados e até conseguir obter as primeiras colheitas após o estabelecimento no lote, levavam-se vários meses, ultrapassando até um ano, às vezes.

Diante desse quadro, o imigrante tornava-se bastante vulnerável em relação ao comerciante da colônia, que tanto comprava a produção do imigrante, quanto vendia mercadorias diversas. O comerciante exigia dos diretores da colônia a emissão de bônus para os imigrantes, como forma de assegurar o pagamento das dívidas contraídas no comércio. "Os bônus, com a desculpa de que eram de validade incerta, eram descontados dos colonos com desfalques percentuais. Às vezes, como o bônus era um documento único, o comerciante se apropriava indevidamente de certas cifras" (GROSSELLI, 2008, p.264).

Essa relação de pagamento era adotada pelos comerciantes de Porto de Cachoeiro e afetava tanto o imigrante, quanto o pequeno comerciante que não fazia parte dela. Como, muitas vezes, o dinheiro não chegava até o imigrante e era repassado diretamente para o comerciante, estabelecia-se uma relação de exclusividade. $\mathrm{O}$ imigrante só podia consumir em um determinado estabelecimento 
comercial, o que facilitava a cobrança de preços abusivos e excluía o pequeno comerciante.

Em Santa Leopoldina, antes mesmo de começar a vender sua produção, muitos imigrantes já estavam "nas mãos" do comerciante. Essa já era uma manifestação do início da constituição de uma estrutura de comercialização que subordinou fortemente a produção, conforme será abordado mais adiante.

Os conflitos não eram pelo acesso à propriedade da terra, uma vez que essa era assegurada, mas pelo acesso aos incentivos oferecidos ao imigrante. Os conflitos estavam relacionados às dificuldades das colônias e do Estado, nas variadas esferas, em implementar a política de colonização.

Por sua vez, levas e mais levas de imigrantes entraram em Santa Leopoldina, que foi a colônia que mais recebeu imigrantes no Espírito Santo. Foram aproximadamente 10.071 imigrantes, conforme tabela 4. Não se têm dados acerca do número de imigrantes que se retirou da colônia, mas apenas alguns relatos de grupos ou famílias de imigrantes que solicitaram ou foram transferidos para outra colônia. Levando-se em conta a desorganizada estrutura administrativa da colônia, vários imigrantes devem ter abandonado Santa Leopoldina sem que haja qualquer registro.

Santa Leopoldina foi colônia imperial durante 26 anos. Até 1871, 14 anos após a sua fundação, haviam entrado apenas 1.755 imigrantes (APES, 2013). Somente a partir da década de 1870 é que a imigração se torna bastante expressiva. Em 1872, a população já totalizava 2.816 habitantes (APES, 2013), bem como já haviam sido distribuídos 881 lotes e a área da colônia era de $266.502 .500 \mathrm{~m}^{2}$, dos quais 42.042 . $875 \mathrm{~m}^{2}$ eram cultivados (GROSSELLI, 2008).

Somente dois anos depois, em 1874, a área da colônia havia sido duplicada, passando para $514.250 .000 \mathrm{~m}^{2} \mathrm{e}$ ao final de 1876 , a população era superior a 7.000 habitantes (GROSSELLI, 2008). Esses dados tomam dimensão maior quando se considera os indicadores populacionais do Espírito Santo. Em 1890 a população do estado totalizava 135.997 habitantes e a da capital, 16.887 (IBGE). Acrescente-se também, que em 1878, Santa Leopoldina "era uma das colônias mais populosas do Império, superada apenas por Blumenau e Dona Francisca, ambas em Santa Catarina" (PETRONE, 2004, p 28). 
A população foi crescendo e a colônia se expandindo. Durante as duas primeiras décadas após a fundação da colônia os imigrantes estabeleceram-se no núcleo Santa Maria, (Figura 1) a oeste da sede da colônia, no vale do rio Santa Maria da Vitória. Eram imigrantes de várias partes da Europa, como alemães, suíços, poloneses, mas a maioria era originária da Pomerânia 4 .

$\mathrm{Na}$ década de 1870 foram fundados dois núcleos: Timbuí, em 1874, corresponde ao município de Santa Teresa e Santa Cruz, em 1877, corresponde ao município de Ibiraçu (Figura 1). Ambos receberam predominantemente imigrantes italianos. Esses núcleos foram localizados ao norte da sede administrativa da colônia, o primeiro na bacia hidrográfica do rio Timbui e o segundo na bacia hidrográfica do rio Piraqueaçu. O movimento de expansão da colônia na direção norte se explica pela busca de terrenos com menor altitude e mais aptos à cultura do café.

Inicialmente a sede da colônia foi situada na localidade de Suíça, situada a aproximadamente quatro milhas acima da Cachoeira do Funil (COSTA, 1982, p.16). A escolha desse local foi arbitrária e decorrente do crescimento da colônia sua sede foi transferida em 1867 para Porto de Cachoeiro de Santa Leopoldina, uma localidade a jusante da primeira sede.

Situado às margens do rio Santa Maria da Vitória, mais especificamente no trecho encachoeirado que se constituía em um limite natural para a navegação, Porto de Cachoeiro de Santa Leopoldina era um pequeno povoado que foi constituído anteriormente à fundação da colônia. Devido à localização estratégica, pois da capital até esse povoado o rio era navegável e, dessa forma, possibilitava o transporte de mercadorias. Decorrente da fundação e do crescimento da colônia, o comércio se intensifica e esse povoado torna-se a sede da colônia (Figura 2).

Constituiu-se aí o limite de comunicação fluvial entre a colônia de Santa Leopoldina (porto fluvial) e a capital do Espírito Santo, onde estava localizado o porto de exportação, Vitória. Com essa localização, Santa Leopoldina por várias décadas, monopolizou a comercialização da produção da região onde estava inserida e, dessa forma, sua sede transformou-se em um importante entreposto comercial, por onde

\footnotetext{
${ }^{4}$ É comum na literatura sobre imigração europeia no Espírito Santo, considerar o pomerano como alemão ou germânico. No entanto, os pomeranos são de origem eslava e quando migraram para o Espírito Santo, a Pomerânia era uma província da Prússia.
} 
tanto entravam as mercadorias importadas pelo porto de Vitória, quanto escoavam a produção, sobretudo, de café para exportação.

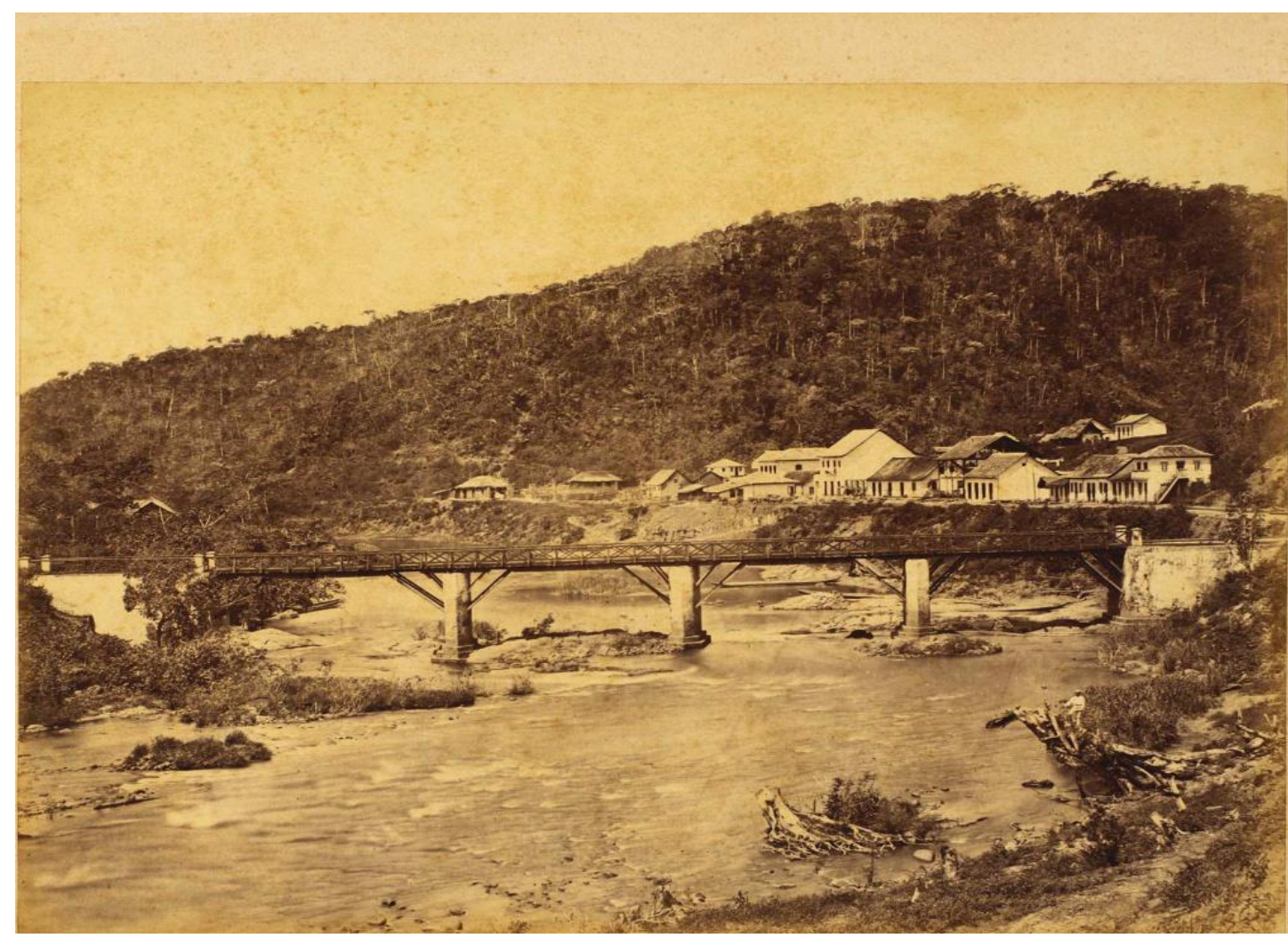

Figura 2: Sede de Santa Leopoldina - Rua do Comércio e seu casario onde se constituiu um importante entreposto comercial. Na frente, a ponte atravessando o rio Santa Maria da Vitória e construída sobre as pequenas cachoeiras onde o rio deixava de ser navegável. Ao fundo, o morro ainda coberto pela Mata Atlântica.

Fonte: DIETZE, 1877.

Como o sistema de transporte era bastante precário, as mercadorias eram transportadas de forma bem tradicional. Exemplificando, o café era transportado em tropas de muares da propriedade até o vendeiro e depois para a sede da colônia, onde era transferido para o modal fluvial e, então, seguia para o porto da capital em canoas de madeira com capacidade, em média, para 100 sacas de café (COSTA, 1982). Conduzidas pelos canoeiros, as canoas desciam o rio carregadas de café e voltavam com mercadorias diversas, das quais uma parte era destinada ao comércio da sede e outra era distribuída, pelos tropeiros, para o comércio localizado no interior da colônia e até mesmo em Minas Gerais.

O rio tornou-se uma condição geral de produção ao proporcionar o transporte das mercadorias tanto produzidas quanto consumidas pela colônia. As condições gerais de produção, um conceito marxista resgatado por Lencioni (2007), "articulam 
o particular ao geral, são consumidas coletivamente e encontram nos equipamentos de consumo coletivo os suportes materiais e imateriais de sua existência" (p.5).

Embora o rio seja um bem natural não produzido pelo trabalho humano, mas ao ser usado para o transporte da produção de mercadorias passou a ser consumido, mas um consumo coletivo de vários capitais, sobretudo dos comerciantes da colônia. Dessa forma, o rio tornou-se uma condição viabilizadora da produção da colônia de Santa Leopoldina e naquele momento, encurtou as distâncias, reduziu o tempo e acelerou a reprodução do capital. Naquela época,

\begin{abstract}
A inexistência de vias de transporte constituía problema crônico e comum a todos os núcleos, dependentes na maioria dos casos do transporte fluvial. Os que mais se desenvolveram, foram exatamente aqueles situados às margens dos rios de melhor navegabilidade, como o núcleo de Santa Leopoldina, à margem do rio Santa Maria, navegável em seus $52 \mathrm{~km}$ até a capital (ROCHA; COSSETTI, 1983, p. 52).
\end{abstract}

Por sua vez, o comerciante que se estabeleceu na sede da colônia era de segunda classe, ou seja, representava aquele elo da cadeia de comercialização entre o exportador da capital e o vendeiro (figura 3). Constituíram-se importantes casas comerciais na colônia e, posteriormente, quando Santa Leopoldina já havia sido transformada em município, alguns desses comerciantes tornaram-se até exportadores.

Os próprios imigrantes é que se tornaram comerciantes de $2^{a}$ classe. No entanto, eram imigrantes que vieram para a colônia com algum recurso e, portanto, diferenciavam-se da maioria dos seus pares. As três maiores casas comerciais estabelecidas na sede da colônia pertenciam a imigrantes europeus. Para exemplificar, Vervloet Irmãos \& Cia., era de propriedade de uma família belga, J. Reisen \& Cia., era de uma família luxemburguesa e Muller \& Cia., de uma família alemã. 


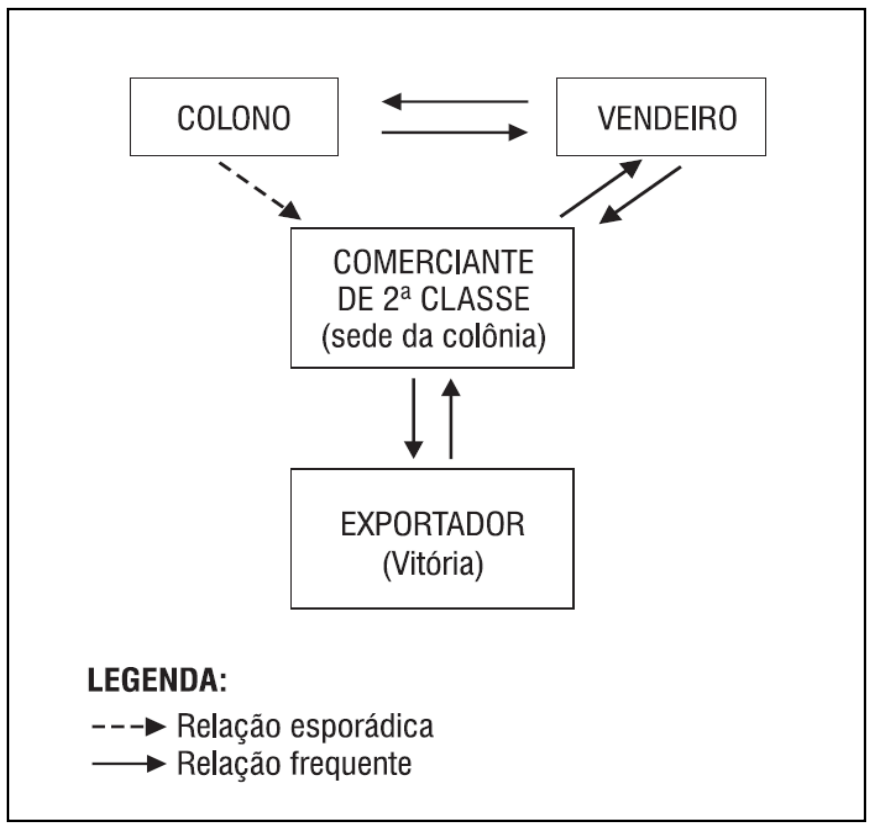

Figura 3: Cadeia de Comercialização.

Elaboração: BERGAMIN, M, C.

Por sua vez, o outro elo da cadeia de comercialização, o vendeiro, normalmente um imigrante também, era um pequeno comerciante sem funcionários, estabelecido no interior da colônia, geralmente nas proximidades de uma igreja, com um número de clientes em torno de 30 famílias, aproximadamente (WAGEMANN, 1949). O pequeno número de clientes tornava muito estreita a relação entre o vendeiro e o imigrante. $O$ vendeiro tornou-se um indivíduo muito importante na vida social do imigrante e seus descendentes, exercendo uma grande influência nesses sujeitos sociais, uma vez que

\begin{abstract}
"O vendeiro é a pessoa com quem o colono se aconselha quando está em dificuldade e apuros. Conforme o caso, tem de desempenhar o papel de intérprete, de conselheiro jurídico e econômico, ou de médico; tem de batizar os filhos dos fregueses e de assumir a tutela quando morrem os pais. As decisões da comunidade dependem do que se assentou previamente na venda e, muitas vezes, o vendeiro exerce, então, influência decisiva" (WAGEMANN, 1949, p. 66).
\end{abstract}

Naquela época havia poucos canais de comunicação e o colono recebia informações sobre o preço do café somente do vendeiro. O colono, um pequeno produtor de café, vendia a sua produção pelo preço definido pelo vendeiro. E era também no comércio desse vendeiro, denominada venda, que o colono adquiria as mercadorias necessárias à sua sobrevivência. Considerando ser essa relação fundada em vínculos pessoais, verifica-se que 
Se por um lado este tipo de relacionamento torna pessoal o ato de compra e venda, por outro lado, este mesmo ato constitui-se algo desfavorável ao colono. Não que o vendeiro use de má fé nos seus negócios: mas porque sua condição de monopolista na compra e venda acaba por perpetuar um quadro desfavorável aos colonos (BUFFON, 1992, p. 126).

Praticamente a única fonte de renda monetária desse colono provinha do café e se concentrava em uma única época do ano, pois a cultura fornece somente uma colheita anual em oposição às necessidades de consumo da família que são distribuídas ao longo do ano. Nessas circunstâncias muitas vezes não havia uma relação monetária entre colono e vendeiro, mas somente troca de mercadorias.

Os preços do café e das poucas mercadorias da venda eram definidos pelo vendeiro, mas amplamente influenciados pelos comerciantes de segunda classe, situados na sede da colônia. Nessa estrutura de comercialização

Os comerciantes eram os únicos que na colônia brasileira tinham a oportunidade de fazer fortuna. Todo o trabalho dos camponeses acabava em suas mercearias e eles eram obrigados a comprar tudo o que necessitavam sempre nos mesmos lugares, a preços de monopólio (GROSSELLI, 2008, p. 225).

Ocorre que no Espírito Santo, a subordinação da produção ao comércio foi muito acentuada em função da predominância da pequena propriedade (CAMPOS JR., 1996). A partir da formação das colônias, constituiu-se uma estrutura de comercialização do café que se diferencia da vigente nas grandes propriedades da região sul do Estado, onde à semelhança dos demais estados produtores de café, "gradativamente os exportadores passaram a comprar café direto do fazendeiro, eliminando com isso a figura do comissário" (ROCHA; COSSETTI, 2003, p. 70)

Isso significa que a produção realizada em grandes propriedades no Espírito Santo não estava subordinada ao comércio no mesmo patamar das colônias, onde, em torno do café, constituiu-se uma estrutura de comercialização formada pelo vendeiro, pelo comerciante de segunda classe e pelo exportador. Surgiu então uma importante classe de comerciantes, os quais acabaram

concentrando a captura do excedente produtivo para a esfera da comercialização, ficando, de um lado, um imenso número de pequenos produtores e, de outro, uma cadeia extremamente articulada de casas comerciais controladoras de expressiva fração da comercialização do café capixaba" (CAMPOS JR., 1996, p. 83). 
Em sua pequena propriedade familiar, o colono tinha como produção principal uma cultura destinada prioritariamente ao mercado externo. A cafeicultura era praticamente a única atividade com importância comercial e, dessa forma, havia uma estrutura que facilitava o seu comércio. Além do café, cultivava-se diretamente para o consumo familiar, ou seja, produzia-se diretamente os meios de vida, como milho, feijão, batata, mandioca, arroz e cana de açúcar, além da criação de pequenos animais, principalmente aves e suínos, e da produção de embutidos. Para esses produtos praticamente não havia mercado e o café, inquestionavelmente, apresentava-se como melhor alternativa econômica.

Simultaneamente, a propriedade familiar do colono combinava duas atividades econômicas: uma voltada para a produção direta dos meios de vida e outra para a produção de mercadorias (SANTOS, 1978). No entanto, a reprodução da força de trabalho da família era assegurada, sobretudo, pela produção direta dos meios de vida e não pela cafeicultura. A produção mercantil de café possibilitava adquirir na venda alguns produtos manufaturados. Uma das condições que permitia que a produção mercantil de café fosse tão intensamente subordinada ao comércio, era justamente a produção direta dos meios de vida do colono, pois

\begin{abstract}
Ainda que com inúmeras dificuldades, o produtor capixaba dispunha do produto do seu trabalho, que se desdobrava num fluxo de renda monetária e noutro de valores de uso, sendo o primeiro, apesar de essencial às condições de vida no campo, mesmo que drasticamente comprimido em alguns momentos, não colocava em questão a reprodução do estabelecimento (BUFFON, 1992, p. 110).
\end{abstract}

Obtendo pequena produtividade na cafeicultura que ainda era fortemente subordinada ao comércio, o colono, por muitos anos, assegurava pouco mais que a reprodução simples. Um conceito marxista, que transposto para a forma social de produzir do colono, significa que este "repõe, a cada ciclo produtivo, seja por via da produção direta, seja por ia da troca monetária, os meios de produção e a força de trabalho necessários para a simples repetição da produção" (SANTOS, 1978, p. 66 e 67). Em outras palavras, a produção é renovada no mesmo nível da anterior e não ocorre acumulação no âmbito produtivo.

Em Santa Leopoldina o colono, por meio do trabalho da família, acumulava um pequeno excedente produtivo, mas que era capturado na esfera comercial, uma vez que "além de proprietário da terra, era dono do produto. Mesmo baixo, o 
excedente gerado na pequena propriedade familiar, significava uma remuneração além da subsistência, apesar de apropriado em grande parte pela esfera da circulação" (MACEDO, 2013, p.23).

Ocorre que no Espírito Santo constituiu-se uma estrutura produtiva bastante peculiar em decorrência da política de criação das colônias e da introdução do imigrante estrangeiro. As características fundamentais dessa estrutura produtiva eram o predomínio da pequena propriedade, do trabalho familiar, da ausência de recursos técnicos e a cafeicultura com principal atividade. Em Santa Leopoldina não foi diferente e essa estrutura produtiva originada nas colônias tornou-se predominante e foi reproduzida na ocupação espacial da maior parte do Estado. Nesse sentido,

A estrutura produtiva daí surgida e reproduzida veio constituir-se num dos principais condicionantes de todo o processo de desenvolvimento posterior da economia local, tendo se transformado no mais característico traço da produção cafeeira no século XX (ROCHA; COSSETTI, 2003, p. 43).

O café era plantado nas encostas em fileiras, sem obedecer às curvas de nível, intensificando a erosão dos solos e reduzindo a vida útil do cafeeiro. Normalmente não se fazia mudas de café e se plantava diretamente com as sementes. Solos com baixa fertilidade natural e erodidos, associados à ausência de recursos técnicos, resultavam em baixos níveis de produtividade da cultura.

Por sua vez, passados alguns anos após sua fundação, a colônia de Santa Leopoldina tornou-se uma importante produtora de café no Espírito Santo, com expansão progressiva da cultura. Em 1884 Santa Leopoldina produzia 40\% do café da região da capital e $16 \%$ de toda a Província do Espírito Santo (ROCHA e COSSETTI, 1983 apud AGUIRRE, 1934). Quando se compara a produção das duas maiores colônias do Espírito Santo, verifica-se em Santa Leopoldina um volume bem mais considerável de exportação de café do que em Rio Novo, conforme tabela 2.

Após quase três décadas de existência, em 1882 a colônia de Santa Leopoldina foi emancipada pelo governo imperial e partir desse momento deixou de receber os recursos específicos que eram concedidos a uma colônia. Nos dois anos que seguiram a emancipação, Santa Leopoldina passou a fazer parte do município de Vitória. No entanto, em 1884 a ex-colônia foi transformada em município, desmembrando-se de Vitória. 
Tabela 2

Exportações de café das colônias de Rio Novo e Santa Leopoldina, 1875/1885

\begin{tabular}{l|c|c}
\hline Ano & Rio Novo & Santa Leopoldina \\
\hline $\mathbf{1 8 7 5}$ & $186.000 \mathrm{~kg}$ & $1.028 .230 \mathrm{~kg}$ \\
$\mathbf{1 8 7 7}$ & $293.780 \mathrm{~kg}$ & $880.000 \mathrm{a} 1.175 .000 \mathrm{~kg}$ \\
$\mathbf{1 8 7 8}$ & - & $1.500 .000 \mathrm{~kg}$ \\
$\mathbf{1 8 7 9}$ & $400.000 \mathrm{~kg}$ & - \\
$\mathbf{1 8 8 3}^{\star}$ & $1.812 .500 \mathrm{~kg}$ & $2.000 .000 \mathrm{~kg}$ \\
$\mathbf{1 8 8 5}^{\star}$ & $2.033 .500 \mathrm{~kg}$ & $3.750 .000 \mathrm{~kg}$ \\
\hline
\end{tabular}

Fonte: Grosselli, 2008, p. 496. Dados extraídos do GDG, Segunda Série (383L), livro 71 e GDA, Segunda Série, livro 34, ambos do Arquivo Público do Espírito Santo). *Embora na década de 1880 ambas as colônias já fossem emancipadas, considerouse os dados de 1883 e 1884 como forma de mostrar o crescimento econômico de Santa Leopoldina.

Plenamente em conformidade com os objetivos iniciais da política imperial, a colônia promoveu a ocupação espacial, valorizou as terras e contribuiu para o crescimento econômico do Espírito Santo. Localizada distante do sul da província, onde se concentrava a localização das fazendas escravistas, a colônia, em momento algum, esteve à margem da grande propriedade e tampouco lhe forneceu mão de obra.

\subsection{A chegada dos imigrantes na colônia de Santa Leopoldina e o início da formação do território que constituirá Santa Maria de Jetibá}

Durante mais de uma década após a fundação da colônia de Santa Leopoldina, os imigrantes foram fixados somente no núcleo Santa Maria, localizado próximo à sede da colônia. Nos anos 1870 a imigração aumentou consideravelmente na colônia e foram criados mais dois núcleos, Timbuí em 1874 e Santa Cruz em 1877. No entanto, interessa-nos a ocupação do núcleo de Santa Maria, onde se iniciou a formação do território que corresponde, no presente, ao município de Santa Maria de Jetibá, o recorte espacial dessa tese.

Do porto de Vitória até a sede da colônia, os imigrantes eram transportados em canoas, numa viagem de aproximadamente 12 horas pelo rio Santa Maria da Vitória. Na sede da colônia eram alojados nos precários barracões, onde muitos imigrantes permaneceram por vários meses até a demarcação dos lotes. Da colônia 
até o lote, normalmente o transporte era feito a pé e usavam-se mulas para carregar os baús contendo os escassos objetos pessoais, alimentos e instrumentos de trabalho. É importante ressaltar que esse trajeto não é válido para os imigrantes do núcleo Santa Cruz, os quais utilizaram outro rio, o Piraqueaçu, para chegar até a colônia.

Após a fixação do imigrante na colônia, iniciava-se uma fase marcada pela penúria e pelo enfrentamento de inúmeras dificuldades para assegurar simplesmente a sua sobrevivência e a de sua família. Dispondo de poucos instrumentos de trabalho, a tarefa de tornar o lote de terra produtivo e construir as edificações (Figura 4), era uma empreitada bastante penosa.

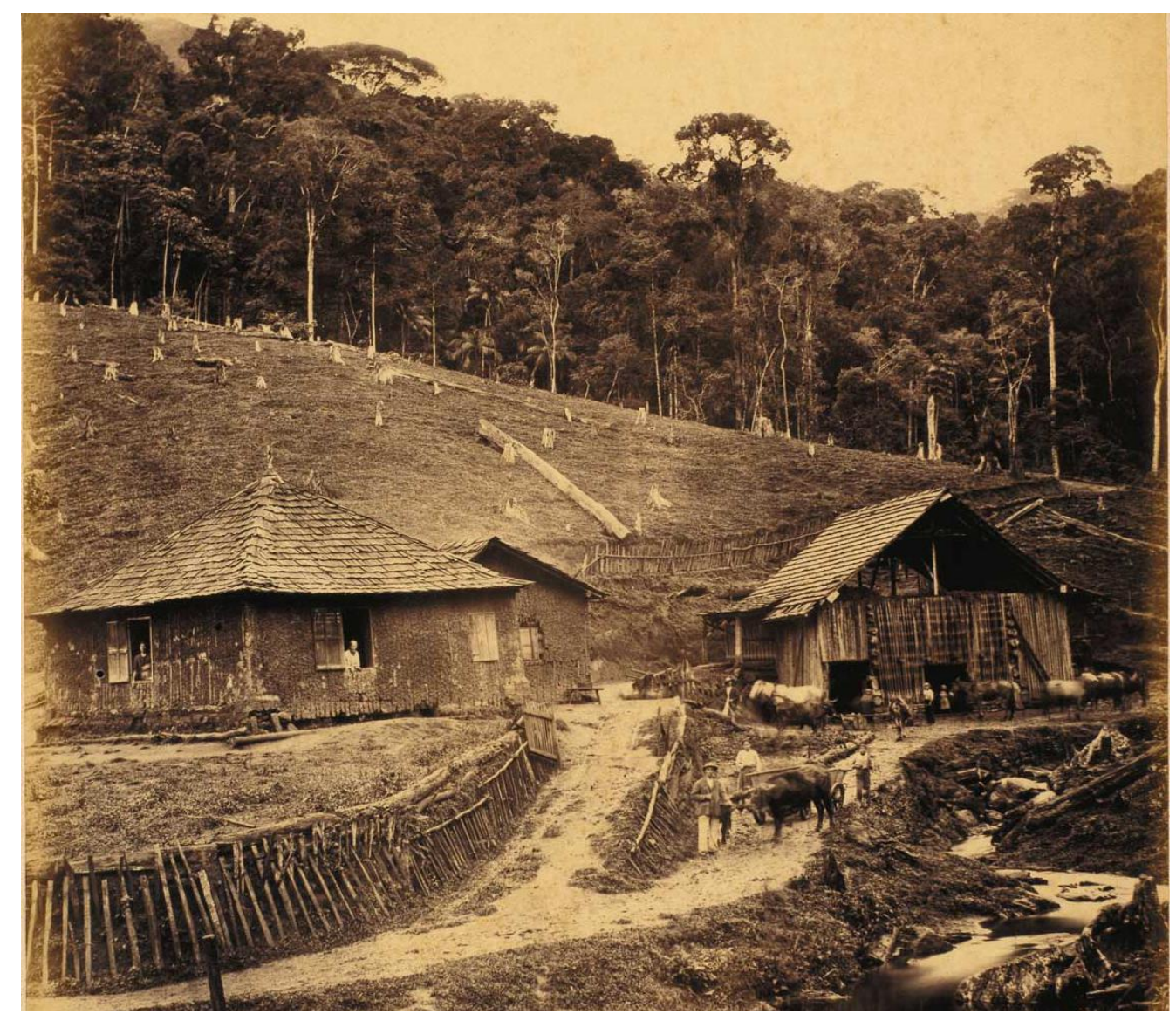

Figura 4: Propriedade rural - Propriedade do imigrante Ignaz Helmer aparentando ser bem estabelecida para os padrões da época, com edificações, alguns animais e uma parte do terreno já desmatada e ocupada por pastagens. As edificações compostas por uma casa, uma cozinha e um galpão para guardar a produção e os instrumentos de trabalho e abrigar animais, eram construídas com os materiais disponíveis na propriedade. Na frente, um pequeno curso d'água para abastecer a propriedade, uma condição fundamental para assegurar a reprodução da propriedade.

Fonte: DIETZE, 1877. 
Analisando as condições de estabelecimento do imigrante europeu nas colônias do Espírito Santo, Grosselli (2008) afirma que

Talvez o período mais difícil na vida dos emigrantes europeus no Brasil no
arco de tempo que nos interessa foram as semanas, às vezes meses, que
estes viveram nos barracões e os primeiros tempos em que tiveram que
adentrar a floresta e criar para si espaços de vida. O camponês era lançado
em uma desoladora voragem de desespero pela pungente desilusão que
sofria ao chegar ao Brasil. Tudo era o oposto do que esperara e sonhara.
Não havia uma comunidade na qual se pudesse inserir, não existiam
estruturas sociais: nem padres, nem igrejas, médicos ou hospitais. Não
havia sequer cidades, aldeias, hospedarias, nem mesmo uma casa fora
preparada para ele, e assim a sua terra era apenas um vasto horizonte de
vegetação que não se assemelhava àquela a que estava habituado. A
floresta era um intrincado aglomerado de vegetação que parecia repelir o
homem (p. 396).

Considerando que no início a colônia praticamente não possuía nenhuma infraestrutura, os primeiros imigrantes foram os que enfrentaram as maiores dificuldades. Como exemplo, os suíços, constituídos por um grupo de 113 pessoas, foram os primeiros imigrantes a se fixarem na colônia em 1857 (tabela 3) e logo os problemas começaram a se manifestar. Tratava-se de um grupo de imigrantes, os quais em decorrência das reclamações feitas por um cônsul suíço foram liberados pelo governo imperial dos contratos de parceria estabelecidos em fazendas de Ubatuba em São Paulo (TSCHUDI, 2004).

Os suíços foram instalados no núcleo Santa Maria da Vitória, em um local que denominaram Suíça (SEIDE, 1980). Após o penoso trabalho do desmatamento, assim que começaram a cultivar a terra os resultados obtidos pelas colheitas não foram desejáveis. Questionaram então a fertilidade dos solos e solicitaram a transferência para outra parte da colônia. A solicitação foi atendida, esses imigrantes foram transferidos para outra parte do núcleo Santa Maria, mas de acordo com o ritmo da precária estrutura administrativa da colônia.

Em 1860 Tschudi, enviado pelo governo suíço para verificar a situação do imigrante suíço no Brasil, visitou Santa Leopoldina. Bastante contundente, o relatório por ele elaborado apresentava críticas severas acerca da situação dos suíços em Santa Leopoldina. "Que perspectiva triste para uma colônia agrícola que, após quatro anos de existência, seus habitantes precisam ser auxiliados diretamente com dinheiro para comprarem seus próprios mantimentos" (TSCHUDI, 2004, p.76 e 77). 
Tabela 3

Colônia de Santa Leopoldina: entradas de imigrantes por procedência e ano $(1857$ a 1882)*

\begin{tabular}{|c|c|c|c|c|c|c|}
\hline & Pomeranos & Alemães & Italianos & Poloneses & Outros & Total/anual \\
\hline 1857 & 0 & 39 & 0 & 0 & 113 & 152 \\
\hline 1858 & 0 & 151 & 0 & 0 & 87 & 238 \\
\hline 1859 & 144 & 162 & 0 & 0 & 189 & 495 \\
\hline 1860 & 31 & 193 & 0 & 0 & 74 & 298 \\
\hline 1861 & 0 & 11 & 0 & 0 & 71 & 82 \\
\hline 1862 & 0 & 0 & 0 & 0 & 39 & 39 \\
\hline 1863 & 0 & 2 & 0 & 0 & 2 & 4 \\
\hline 1864 & 0 & 0 & 0 & 0 & 2 & 2 \\
\hline 1865 & 0 & 1 & 0 & 0 & 0 & 1 \\
\hline 1867 & 0 & 0 & 0 & 0 & 5 & 5 \\
\hline 1868 & 31 & 18 & 0 & 0 & 7 & 57 \\
\hline 1869 & 382 & 11 & 0 & 0 & 5 & 398 \\
\hline 1870 & 3 & 0 & 0 & 0 & 0 & 3 \\
\hline 1871 & 1 & 0 & 0 & 0 & 0 & 1 \\
\hline 1872 & 519 & 96 & 0 & 445 & 449 & 1509 \\
\hline 1873 & 962 & 2 & 0 & 118 & 118 & 1200 \\
\hline 1874 & 59 & 11 & 396 & 0 & 0 & 466 \\
\hline 1875 & 15 & 15 & 784 & 0 & 6 & 820 \\
\hline 1876 & 4 & 22 & 2060 & 0 & 6 & 2092 \\
\hline 1877 & 7 & 0 & 1797 & 0 & 30 & 1834 \\
\hline 1878 & 2 & 0 & 61 & 0 & 0 & 63 \\
\hline 1879 & 1 & 0 & 110 & 0 & 5 & 116 \\
\hline 1880 & 37 & 19 & 109 & 0 & 0 & 165 \\
\hline 1881 & 9 & 1 & 0 & 0 & 0 & 10 \\
\hline 1882 & 10 & 0 & 11 & 0 & 0 & 21 \\
\hline Total & 2217 & 754 & 5328 & 563 & 1208 & 10071 \\
\hline
\end{tabular}

Fonte: Arquivo Público do Espírito Santo, 2013.

Entraram também outros grupos de imigrantes, mas em menor quantidade. São eles: 246 holandeses, 142 suíços, 127 austríacos, 89 luxemburgueses, 34 americanos, 17 franceses, 11 belgas, 10 espanhóis, 8 venezuelanos e 2 ingleses.

Elaboração: BERGAMIN, M., C.

Isso ocorria porque Santa Leopoldina, como era comum entre as colônias brasileiras, não dispunha de uma estrutura adequada que sustentasse a imigração conforme os padrões estabelecidos pelo império. "A Província não estava preparada para a chegada de imigrantes. A própria nação não conhecia estruturas burocráticas e técnicas adequadas a este fim. Infelizmente, esta situação não melhoraria muito nas décadas seguintes" (GROSSELLI, 2008, p. 200).

Acerca dos solos do Espírito Santo, de forma geral são de baixa fertilidade, a exceção de algumas áreas. Ao se desmatar, rompia-se o equilíbrio de um sistema 
fechado que sustentava a Mata Atlântica e mantinha os solos férteis. Os solos expostos e localizados em terrenos íngremes, como na colônia de Santa Leopoldina, eram lavados pelas chuvas. Em poucos anos a fertilidade dos solos tornava-se bastante reduzida.

Em uma época na qual os progressos técnicos da agricultura capixaba eram extremamente limitados, a fertilidade natural dos solos assumia elevada importância para a produção agrícola, constituindo-se em um fator determinante para o desenvolvimento agrícola. Decorrente de um fator natural, no Espírito Santo os níveis de produtividade da cafeicultura eram os menores entre as demais regiões produtoras de café.

Ainda em 1857 também começaram a chegar os primeiros imigrantes alemães, cujo fluxo foi mais intenso nos anos iniciais da colônia (tabela 3) e fixaramse também no núcleo Santa Maria. Dessa forma, por aproximadamente um período correspondente à metade do tempo de existência da colônia, os alemães foram predominantes. Quando a colônia se emancipou, os alemães constituíam o terceiro maior grupo de imigrantes de Santa Leopoldina, conforme tabela 3.

Segundo SEIDE (1980), D. Pedro I deu preferência aos imigrantes de fala alemã para agradar a imperatriz Dona Leopoldina de Habsburgo. Verifica-se que a maioria dos imigrantes que entraram em Santa Leopoldina até o final dos anos 1860, era proveniente de países nos quais o alemão era o ou um dos idiomas falados. É provável que a comunicação na colônia fosse feita principalmente em alemão.

O ano de 1859 marca a chegada dos imigrantes pomeranos, que também se fixaram no núcleo de Santa Maria. Inicialmente entrou um número reduzido de imigrantes, mas no final dos anos 1860 e início dos anos 1970, chegaram em grandes levas e tornaram-se o segundo maior grupo de imigrantes da colônia (Tabela 3) além de terem sido predominantes no núcleo Santa Maria.

Juntamente com os pomeranos, entraram os poloneses. Tratava-se de um grupo numericamente importante, constituído por 563 pessoas (Tabela 3) que se fixaram no núcleo de Santa Maria. Os poloneses foram os principais contestadores das condições de vida da colônia. Enganados por uma agência de imigração da Europa que fez falsas promessas e decepcionados com as condições de 
sobrevivência na colônia, os poloneses estabeleceram uma relação conflituosa tanto com a administração da colônia quanto com os próprios imigrantes.

Revoltados, os poloneses em 1873 se organizaram e se dirigiram para a sede da colônia, onde exigiram o retorno para a Europa. O ocorrido desencadeou um clima de insegurança e a direção da colônia solicitou reforços militares para impor a ordem. Como a solicitação dos poloneses não foi atendida, muitos deixaram a colônia e partiram para o Rio Grande do Sul (GROSSELLI, 2008).

Em 1874 também ocorreram conflitos entre os alemães e a direção da colônia, relativo ao pagamento dos serviços realizados por esses imigrantes em obras de infraestrutura colonial (GROSSELLI, 2008). Esses conflitos ocorriam porque a colônia continuava despreparada para receber os imigrantes.

$\mathrm{Na}$ década 1870, quando entrou a maioria dos imigrantes, a situação da colônia era a seguinte: os lotes ainda não haviam sido medidos em quantidade suficiente, os barracões estavam abarrotados de imigrantes em péssimas condições de hospedagem e na hospedaria de Pedra D'Água em Vitória, centenas de imigrantes aguardavam para serem transferidos para Santa Leopoldina.

Apesar dos imigrantes terem entrado em períodos diferentes, a colônia permaneceu despreparada e nunca conseguiu desenvolver uma estrutura administrativa que executasse os serviços necessários para receber adequadamente os imigrantes. Isso significa que o processo de estabelecimento do imigrante na colônia sempre foi marcado por uma série de dificuldades e conflitos com a administração colonial.

Essa década marca também a chegada dos imigrantes italianos, os quais, conforme pode ser observado na Tabela 3, foram predominantes na colônia de Santa Leopoldina. No entanto, esses imigrantes se fixaram principalmente nos núcleos de Timbuí e Santa Cruz, onde foram majoritários e imprimiram suas características culturais e econômicas. No núcleo Santa Maria a presença do imigrante italiano não foi expressiva.

Diferentemente desses dois núcleos, em Santa Maria fixaram-se imigrantes de procedência muito diversificada, mas conforme abordado, o pomerano foi predominante, seguido pelo alemão. Por causa da diversidade, a administração da colônia buscava agrupar os imigrantes pela nacionalidade ou região de origem. 
Havia a intenção de não misturar muito os imigrantes para tentar manter os vínculos de origem e até mesmo evitar conflitos.

Com os pomeranos não foi diferente e à medida que entraram na colônia, receberam lotes que subiam o rio Santa Maria da Vitória até alcançarem as altitudes mais elevadas, aquelas acima de 1000m. Os pomeranos concentraram-se numa parte da colônia, na qual predomina a zona natural 1, caracterizada por apresentar terras frias acidentadas e chuvosas, segundo a classificação elaborada por FEITOSA (2001). Conforme pode ser observado na Figura 5, que apresenta o mapa planaltimétrico de Santa Leopoldina e dos municípios que surgiram do desmembramento de sua área original, o território ocupado pelos pomeranos e que corresponde ao município de Santa Maria de Jetibá, apresenta altitudes mais elevadas. Nessas condições de localização, os pomeranos

se isolaram nas altas terras, entre morros e rochas graníticas. Mais tarde, depois de sete anos, comercializaram as primeiras colheitas com os vendeiros da região. Anos depois, alguns pomeranos tornaram-se tropeiros levando as sacarias de café e verduras no lombo dos burros passando por caminhos íngremes e depois seguindo de canoa via rio Santa Maria para a capital da Província: Vitória. (HEINEMANN, 2008, p.6).

Segundo Heinemann (2008), esse isolamento dos pomeranos no Espírito santo tem forte relação com a forma como comercializavam a produção agrícola e que se diferenciava de São Lourenço, no Rio Grande do Sul, onde, quando os imigrantes pomeranos chegaram

\footnotetext{
já havia um porto comercial e muitos armazéns de portugueses e brasileiros na beira do cais. Em pouco tempo, famílias pomeranas se deslocavam semanalmente para o porto na tarefa de comercializar tudo o que produziam: fumo, cereais e posteriormente a batata. Com isso, logo, logo se entrosaram e adaptaram-se com a vida dos brasileiros, diferente de outros pomeranos que viveram isolados por dezenas de anos (HEINEMANN, 2008, p.6).
}

Os primeiros a migrarem para a colônia de Santa Leopoldina, dos quais os pomeranos são o grupo mais expressivo numericamente, encontraram uma estrutura de comercialização muito pouco organizada ou até mesmo a ausência de comércio. Majoritários, concentrados nas partes mais altas da colônia e com dificuldades comerciais nos anos iniciais da migração, os pomeranos se isolaram e se fecharam em seu grupo. 


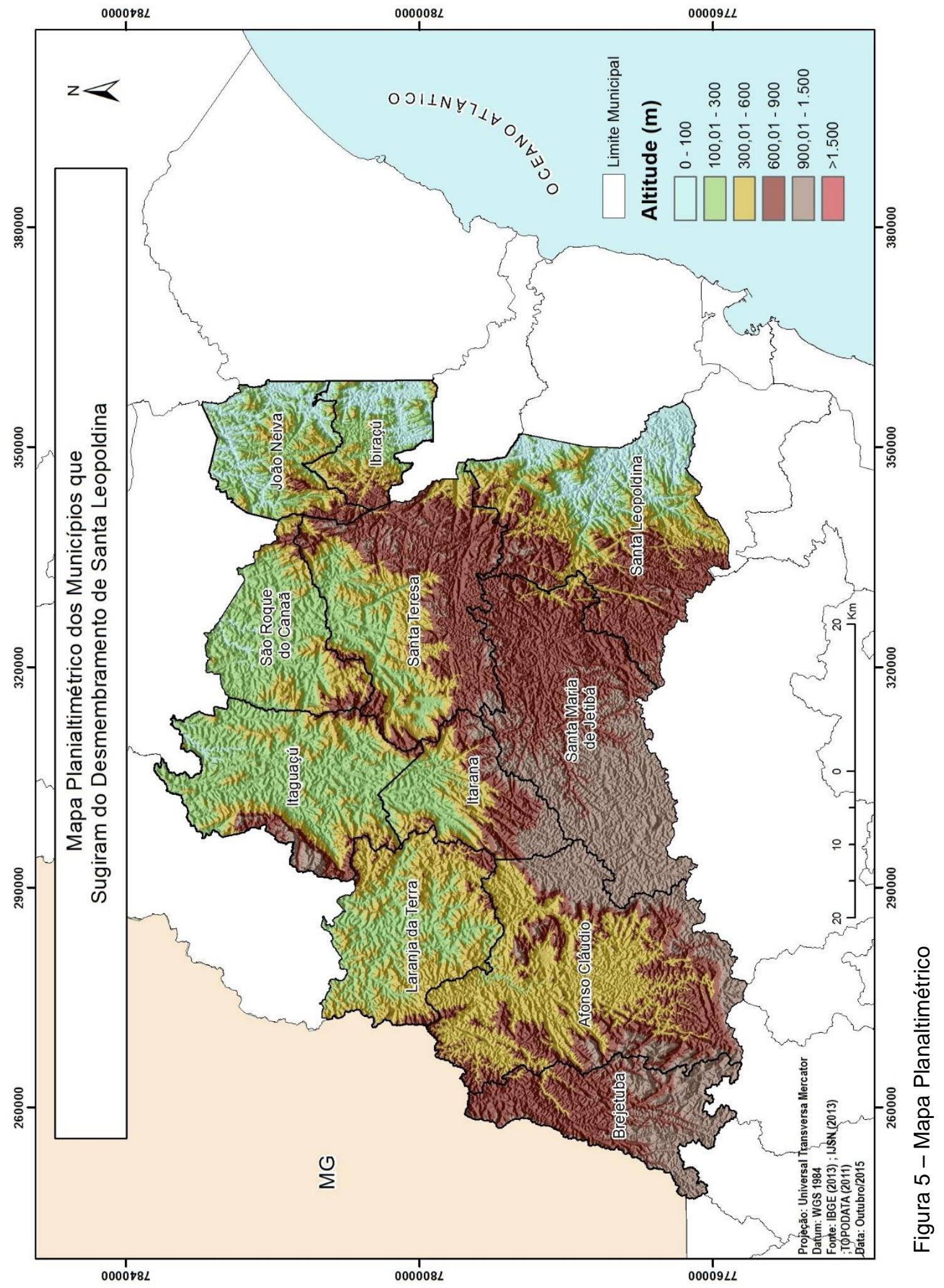


A relação de vários grupos de imigrantes com a direção da colônia foi permeada por muitos conflitos, alguns até demandaram reforços militares, conforme mencionado. No entanto, os pomeranos apresentaram outro tipo de comportamento, o que os diferenciava na colônia, uma vez que desde o início se destacaram como excelentes trabalhadores.

Embora não fossem proprietários de terra antes de migrarem para a colônia, grande parte deles trabalhava na agricultura, atividade na qual tinham experiência milenar (HEINEMANN, 2008), o que contribuía para o enfrentamento da nova realidade vivida em uma colônia de imigrantes. Nessa perspectiva, "Lembramos aqui uma frase do rei da Prússia Frederico II, que reinou de 1746 a 1786, e que visitou algumas vezes a Pomerânia. Certa vez lhe perguntaram sobre os pomeranos e ele respondeu: "São bons soldados e excelentes agricultores" (HEINEMANN, 2008, p.7).

Tanto em relatórios quanto em ofícios encaminhados em diferentes períodos pelos diretores da colônia à presidência da província, muitos elogios foram tecidos aos imigrantes pomeranos. Em relatórios de 1861 e 1864, ainda na fase inicial da colônia, os pomeranos se destacavam como os melhores colonos, "a pérola da colônia", trabalhadores fortes, incansáveis e devido a esses atributos eram facilmente distinguidos dos demais colonos (FERRARI, 1968).

Em 1913, o cientista alemão Wagemann realizou uma pesquisa na região de colonização germânica no Espírito Santo, da qual o território de Santa Maria de Jetibá fazia parte. Neste trabalho, o autor em questão reafirma a distinção dos pomeranos e seus descendentes não somente em relação à capacidade para o trabalho, mas também por elementos da personalidade, como o aspecto reservado e a determinação. Dessa forma, afirma que

Fôrça é convir que os pomeranos, chegados, às centenas, de 1870 a 1879, apesar do Rescrito de Heydt, incentivaram, com sua energia colonizadora, o progresso posterior. É verdade que não estavam acostumados, de casa, a vencer as dificuldades de regiões montanhosas, mas tinham sido jornaleiros de tarefas pesadas e distinguiam pela sobriedade, força de vontade e capacidade de trabalho (WAGEMANN, 1949, p. 26).

Em meio a tantos conflitos entre imigrantes e a administração colonial, chama atenção um ofício 30/06/1873, ressaltando que "os Pomeranos aqui têm mostrado muita moderação, energia para o trabalho e decidida aptidão para a agricultura, tornando-se por isso dignos de atenção" (APES,1873). Em outro ofício, de 
26/07/1873, o diretor da colônia informa que da mesma forma que os outros imigrantes os pomeranos também questionavam os valores dos salários recebidos pelos serviços prestados à colônia e solicitavam aumentos. No entanto, o fato dos salários não serem reajustados não significava para eles a desgraça das suas vidas e tampouco o motivo para se desesperarem com o futuro. (APES, 1873).

Quando os pomeranos migraram para a colônia de Santa Leopoldina, a Pomerânia era uma província prussiana e, portanto, não pertencia a um estado nação. Uma condição, que de certa forma, deixava os pomeranos desamparados na colônia em relação aos imigrantes provenientes de uma nação.

Quando os suíços questionaram a estrutura da colônia, a Suíça encaminhou um cônsul para verificar a situação em que os seus compatriotas se encontravam. Em 1895, decorrente do relatório do cônsul italiano Carlos Nagar acerca das condições em que encontravam os imigrantes italianos no Espírito Santo, a Itália proibiu a imigração para o estado (RIBEIRO, 2008). Embora a Prússia tenha publicado o Rescrito de Heydt em 1859, que somente proibia a propaganda em favor da imigração para o Brasil, essa medida não limitou a imigração para a colônia de Santa Leopoldina, uma vez que todos os pomeranos e a maioria dos alemães entraram na colônia a partir desse 1859.

Sem pertencerem a um estado nação, os pomeranos eram provenientes de uma província onde ocorreram inúmeros conflitos que alteraram profundamente suas fronteiras até desaparecer do mapa e ter sua área incorporada por dois países: Polônia e Alemanha. Além disso, a maioria dos pomeranos que migrou para a colônia de Santa Leopoldina trabalhava como agricultor, mas não era proprietária de terra na Pomerânia. Ao imigrar para a colônia e ter acesso à propriedade da terra com a liberdade de trabalhar para quem the interessassem, os pomeranos encontraram uma oportunidade de refazerem suas vidas, apesar de todos os infortúnios vividos nos anos iniciais da imigração.

A maioria dos pomeranos concentrou-se numa parte do núcleo Santa Maria que atualmente corresponde ao município de Santa Maria de Jetibá. Nessa parte do núcleo o imigrante pomerano foi predominante, seguido do alemão. Com o estabelecimento desses imigrantes, começa a ser delineado o processo de formação de um território, não mais definido somente pelo controle do acesso, conforme foi determinante na colônia, mas por outros aspectos. 
Primeiramente considera-se a produção territorial um processo, uma vez que como um produto das relações estabelecidas entre o homem e a natureza, o território não está acabado ou concluído, mas em constante transformação. Após se estabelecerem nessa parte do núcleo de Santa Maria, começarem a cultivar e a vender a produção, ou seja, de se apropriarem da natureza, os imigrantes iniciam a produção de um território, que vai sendo dominado e apropriado ao mesmo tempo, uma vez que

\begin{abstract}
o território deve ser visto na perspectiva não apenas de um domínio ou controle politicamente estruturado, mas também de uma apropriação que incorpora uma dimensão simbólica, identitária e, porque não dizer, dependendo do grupo ou da classe social a que estivermos nos referindo, afetiva (HAESBAERT,1997, p. 41).
\end{abstract}

Com recursos extremamente rudimentares e escassos, o imigrante colono começa a dominar lentamente a natureza. Na sua pequena propriedade agrícola inicia o desmatamento, seguido pela produção somente para o consumo e posteriormente também para o mercado e assim foi assimilando as técnicas adequadas para a agricultura tropical. Nesse processo de apropriação econômica da propriedade, os imigrantes colonos começam também a se apropriar desse território não só de forma material, mas também simbólica. Começam a imprimir e, dessa forma, dão início à produção de um território, porque

\begin{abstract}
falar em território em vez de espaço é evidenciar que os lugares nos quais estão inscritas as existências humanas foram construídos pelos homens, ao mesmo tempo pela sua ação técnica e pelo discurso que mantinham sobre ela. As relações que os grupos mantêm com o seu meio não são somente materiais, são também de ordem simbólica (CLAVAL, 1999, p.11).
\end{abstract}

Essa dimensão simbólica torna-se relevante na apropriação da parte do núcleo Santa Maria onde os pomeranos e seus descendentes se concentraram e que consiste no recorte espacial dessa tese. Desde a chegada à colônia, os imigrantes pomeranos fecharam-se em seu grupo e se enraizaram nesse território como nenhum outro imigrante. Os pomeranos eram predominantes no núcleo Santa Maria, mas não eram os únicos imigrantes, no entanto sua cultura e sua identidade foram hegemônicas. Nenhum outro grupo de imigrantes das colônias do Espírito Santo se enraizou territorialmente de forma tão intensa como os pomeranos. 
Simultaneamente ao processo de apropriação simbólica e material, ocorre também um processo de dominação. A estrutura de comercialização que se constituiu em torno da cafeicultura, subordinou fortemente a produção ao comércio, de forma que a produção desse território também foi acompanhada de uma estratégia de dominação.

um território é apropriado e ordenado por relações econômicas, políticas e culturais, sendo que essas relações são internas e externas a cada lugar; é fruto das relações (territorialidades) que existem na sociedade em que vivemos e entre esta e nossa natureza exterior. $E$ essas relações são relações de poder, de dominação... (SAQUET, 2006, p. 66).

Trata-se, portanto, da formação de um território que vai ser definido a partir de múltiplas dimensões. O político, o econômico e o cultural são dimensões determinantes na formação territorial de Santa Maria de Jetibá, no entanto, numa relação espaço temporal essas determinações se modificam e, por conseguinte, o território também se altera, conforme será demonstrado ao longo dessa tese. 
2 A tRANSIÇÃo dA PENÚRIA PARA O INÍCIO DO CRESCIMENTO ECONÔMICO: O DECLÍNIO DE SANTA LEOPOLDINA E A EMERGÊNCIA DE JETIBÁ E GARRAFÃO, DISTRITOS QUE FORMARÃO O MUNICÍPIO DE SANTA MARIA DE JETIBÁ

2.1 A estrada concorre com o rio: fim do monopólio fluvial do transporte e a decadência comercial de Santa Leopoldina nos anos 1930

Santa Leopoldina ${ }^{5}$ tornou-se município no final do Império, pela lei provincial no 21 de 1884, a partir do desmembramento de Vitória, capital da província do Espírito Santo. A instalação de Santa Leopoldina ocorreu em 1887 e em 1890 o município foi elevado à categoria de cidade. Embora a instalação do município fosse recente, nos anos de 1890 e 1891, Santa Leopoldina perdeu mais de dois terços de sua área devido a fragmentação para ser criar novos municípios. Desses desmembramentos foram criados Afonso Cláudio e Santa Teresa em 1890 e Ibiraçu em 1891, os quais também foram fragmentados para a criação de novos municípios (figura 6).

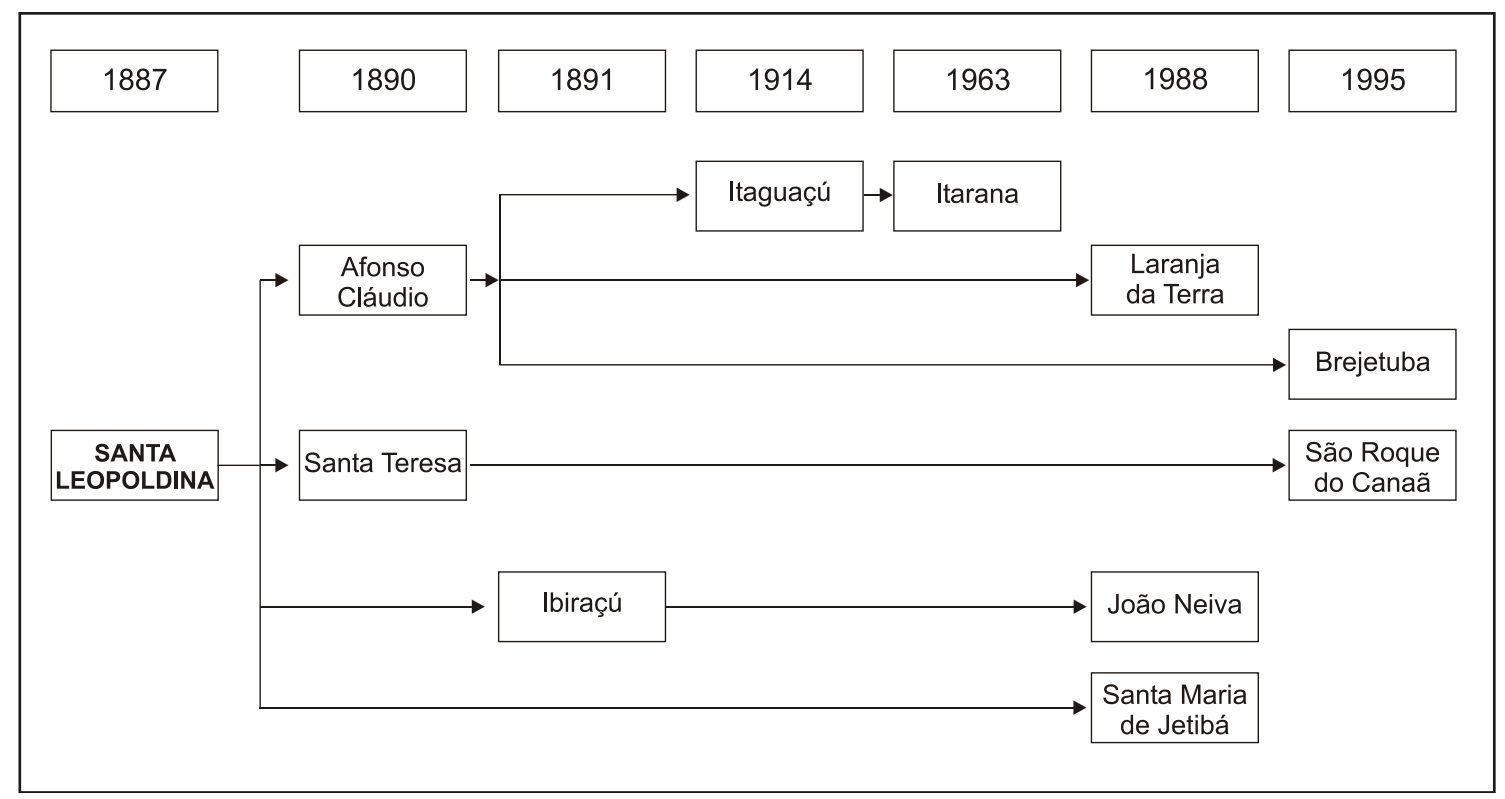

Figura 6 - Municípios criados a partir do desmembramento direto ou indireto de Santa Leopoldina.

Fonte: IBGE, 2015.

\footnotetext{
${ }^{5}$ Primeiramente o município foi denominado Cachoeiro de Santa Leopoldina, mas a partir de 1943 a denominação foi alterada para Santa Leopoldina. Para não confundir o leitor, trataremos o município como Santa Leopoldina.
} 
Embora Santa Leopoldina tenha perdido a maior parte de sua área logo após ter sido transformado em município (Figura 7), isso não interferiu nas suas atividades comerciais. A sede do município, onde estava localizado o entreposto comercial, continuou pertencendo a Santa Leopoldina. Consequentemente o monopólio fluvial do transporte não foi alterado e Santa Leopoldina permaneceu como entreposto comercial não somente para esses novos municípios, mas também para a região onde estava inserida.

À medida que a cafeicultura se expandia nesses municípios por meio da ocupação e da apropriação de novas áreas, o comércio de Santa Leopoldina tomava dimensões maiores. Segundo o Recenciamento do Brasil de 1920, somente em Santa Leopoldina e nos municípios criados a partir da sua fragmentação estavam concentradas quase $1 / 4(23,5 \%)$ das propriedades rurais do Espírito Santo (BRASIL, 1923). Toda essa produção passava pela sede de Santa Leopoldina para seguir, então, de canoa até Vitória e, dessa forma,

\begin{abstract}
O tráfego de canoas era e tinha de ser intenso, uma vez que servia de canal exclusivo para todo o comércio exportador e importador de vastíssima região que, partindo do Pôrto de Cachoeiro de Santa Leopoldina, se espraiava, em forma de leque, para o interior, abrangendo Santa Teresa e Itaguaçu, e estendendo-se até os confina de Afonso Cláudio e Guandú (COSTA, 1982, p. 27 e 28).
\end{abstract}

Embora na região da ex-colônia de Santa Leopoldina predominassem pequenas propriedades, a produção de café estava em franca expansão. A atividade incorporava novas áreas e com altitudes mais adequadas ao cultivo do café, aumentando a produção da região e consequentemente as atividades comerciais na sede do município.

Em que pese todo o dinamismo comercial de Santa Leopoldina, no âmbito da produção a cafeicultura continuava assentada no trabalho familiar e na quase ausência de recursos técnicos, que conferiam à atividade uma baixa produtividade. Dessa forma, permanecia também baixa capacidade de acumulação dos agricultores, majoritariamente familiares, que não ultrapassava muito mais que a reprodução simples da família.

Era nessas condições que ocorria a expansão da cafeicultura e o excedente produtivo, que permanecia sendo capturado pelos comerciantes, também foi 


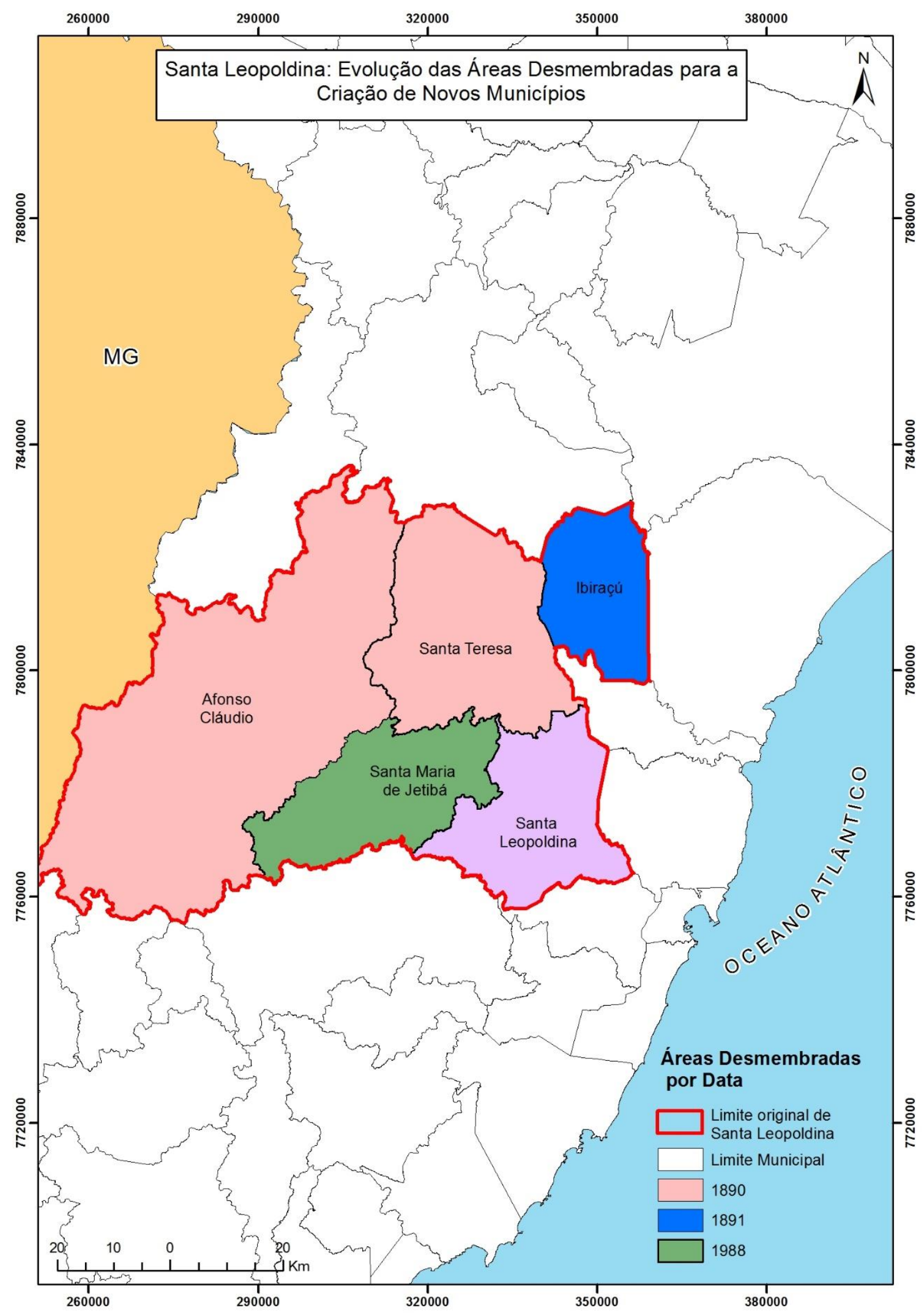

Figura 7 - Santa Leopoldina: evolução das áreas desmembradas para a criação de novos municípios 
ampliado. Além disso, muitos agricultores entregavam uma parte do pouco dinheiro acumulado aos comerciantes, os quais aplicavam em bancos e os juros eram divididos entre as duas partes. Mais uma forma dos comerciantes, agora na esfera financeira, de se apropriar do excedente produtivo dos agricultores.

Para os padrões econômicos capixaba, a sede de Santa Leopoldina era um dos entrepostos comerciais mais dinâmicos e representativos do estado. A população do município também crescia e em 1920, enquanto a capital contava com 21.866 habitantes, esse número chegava a 18.136 em Santa Leopoldina. (BRASIL, 1923). No entanto, é importante salientar, que a estrutura produtiva do Espírito Santo impôs limites à urbanização, e dessa forma produziu

\begin{abstract}
um tipo de urbanização fraca e dispersa: fraca, porque a maioria da população produzia e residia no campo, onde se realizava a quase totalidade da produção material que dava sustentação à vida urbana; dispersa, porque, a despeito de a Capital concentrar parte significativa e crescente da população urbana, ao longo de um século os núcleos nasceram e se fizeram presentes por quase todo o estado, seguindo e dando suporte à expansão cafeeira (BUFFON, 1992, p. 330).
\end{abstract}

Em Santa Leopoldina, a maior parte da população produzia e residia no campo e para sobreviver a dependia muito pouco do mercado e da cidade. Apesar da população do município aproximar-se numericamente da capital, no núcleo urbano de Santa Leopoldina residiam poucos habitantes. Era um núcleo urbano estruturado em torno da cafeicultura, que reservada sua localização estratégica, alcançou importante efervescência comercial. Era o comércio do café que sustentava a cidade.

Perante o dinamismo comercial de Santa Leopoldina, era necessário reduzir o tempo desprendido no transporte das mercadorias e, oportunamente, acelerar o tempo da circulação desenvolvendo outros meios de transporte mais rápidos e com maior capacidade de transportar cargas.

No início do século XX, as estradas de rodagem eram raras no Espírito Santo. Reconhecendo a necessidade da construção de estradas para o crescimento econômico do Estado, o governo Bernardino Monteiro (1916-1920) implementou uma política rodoviária estadual, assentada "primeiramente, no estabelecimento de um Plano Racional de Viação e, consequentemente na implementação desse plano, 
quer diretamente pelo Estado e Municípios, ou pelo fomento à iniciativa privada" (SARTÓRIO, 2007, p. 350).

Para tanto, os proprietários das principais casas comerciais de Santa Leopoldina, J. Reinsen \& Cia, C. Miller \& Cia e Vervloet, Irmãos \& Cia, fundaram a Companhia de Viação Geral que foi responsável pela construção da estrada para automóveis, ligando as sedes dos municípios de Santa Leopoldina e Santa Teresa (COSTA, 1982). Essa estrada foi uma das pioneiras no interior do estado.

Dessa forma, a Companhia Geral de Viação recorreu ao financiamento público para construir a estrada, tomando emprestado $200.000 \$ 000$ contos de réis do governo estadual. Além do crédito, o estado estabeleceu um contrato com a companhia, concedendo-lhe o direito de explorar a estrada por quinze anos (DI FRANCESCO, 2005). Para usar a estrada pagava-se um pedágio à companhia.

Não era uma estrada que concorria com o transporte fluvial e interligava Santa Leopoldina ao Litoral, onde estava a capital e o porto de exportação; pelo contrário, era uma estrada que interligava o município com o interior. A escolha do trajeto da estrada foi estratégica e reforçava os interesses da classe de comerciantes, pois vários caminhos dos municípios vizinhos, usados pelos tropeiros, convergiam para a sede de Santa Teresa, onde também já haviam algumas casas comerciais.

Além disso, nesses municípios vizinhos as condições naturais eram bem mais favoráveis ao cultivo do café do que nas partes de altitude mais elevada de Santa Leopoldina, onde atualmente está localizado o município de Santa Maria de Jetibá. Depreende-se, então, que por razões comerciais, Santa Leopoldina interligou-se primeiro externamente com outro município que canalizava uma parte importante da produção de café da região, para somente algumas décadas posteriores interligarse internamente a outras partes do município.

Com a construção da estrada, as mercadorias passaram a ser transportadas em caminhões de Santa Teresa até Santa Leopoldina. Os primeiros caminhões que circularam pela estrada foram importados da Europa e "Tinham, na época, capacidade de transportar apenas 30 sacas de café. Substituíam, assim, a 15 mulas, com grande economia de tempo" (SCHWARZ, 1992, p. 25).

A estrada, uma condição geral de produção, contribuiu para reduzir o tempo de circulação da mercadoria e acelerou a rotação do capital, mas sem alterar o 
monopólio fluvial do transporte. Os próprios caminhões que circulavam pela estrada foram transportados de Vitória a Santa Leopoldina nas tradicionais canoas pois essa era a única forma viável para se transportar um veículo até o município.

Verifica-se que a mudança nos meios de transporte foi uma realização dos próprios comerciantes e não dos agricultores. De forma geral, para a maioria dos agricultores que eram pequenos proprietários e contavam somente com a mão de obra da família, a produção assegurava não muito mais que a reprodução simples, não havendo na esfera produtiva a acumulação de um excedente que pudesse ser investido em outras atividades econômicas. Verifica-se que pequeno proprietário em Santa Leopoldina,

diferente do fazendeiro paulista, apesar de aparentemente menos explorado, não consegue reter excedente em suas mãos, senão o indispensável à sua reprodução. O próprio tamanho do estabelecimento, correspondendo às dimensões de cultivo que uma família daria conta de conduzir, dificilmente geraria excedente nas mesmas proporções da fazenda paulista. Assim, elimina-se logo a possibilidade de ter havido concentração de excedente na esfera da produção (CAMPOS JÚNIOR, 1996, p.100).

Essa acumulação ocorria na esfera da circulação e foram exatamente os comerciantes da sede de Santa Leopoldina que criaram uma companhia e realizaram investimentos em infraestrutura, no caso a construção da estrada. Uma experiência inédita no Espírito Santo, numa época em que foram raros os investimentos realizados por grupos privados locais.

É importante ressaltar que os tropeiros não desapareceram, pois as estradas de rodagem ainda eram exceção. Esses sujeitos sociais, que atuaram por longo período na região, foram pouco reduzidos e a maioria permaneceu fazendo o transporte de mercadorias.

Perante os avanços nos transportes tanto na escala municipal, quanto estadual, em 1927 a câmara de Santa Leopoldina aprovou a lei ordinária número 69, para subvencionar a construção de outra estrada interligando o município à Cariacica. Para construí-la, a prefeitura teve que enfrentar farta oposição dos comerciantes que previam as consequências negativas que Ihes traria a estrada (CARVALHO, 1978, p. 20). Inaugurada em 1928, a estrada foi construída margeando o Rio Santa Maria da Vitória e acompanhando o caminho de tropeiros existente, até 
atingir Cariacica. Município este que foi interligado por estradas de rodagem à Vitória pela ponte Florentino Avidos também em 1928.

As mercadorias, predominantemente café, que eram transportadas em caminhões vindas de Santa Teresa não precisavam mais parar em Santa Leopoldina para trocar o modal de transporte. Os caminhões seguiam direto para Vitória onde estava o porto e, dessa forma, a estrada concorreu diretamente com o transporte fluvial, derrubando seu monopólio. Inicia-se aí a derrocada de Santa Leopoldina, pois

\footnotetext{
"Quando o governo abriu uma estrada que a ligava à capital, Santa Leopoldina perdeu sua razão de ser (centro comercial nascido da troca de meio de transporte, Umschlagolatz) e suas casas perderam imediatamente o controle do comércio, e logo depois até mesmo a freguesia direta (ROCHE, 1968, p. 236 e 237).
}

De entreposto comercial, Santa Leopoldina tornou-se um local de passagem de mercadorias. Além da interligação por estrada com a capital, "o sistema rodoviário estadual se estendeu até Itaguaçu, Afonso Cláudio e Colatina, condenando, definitivamente, o tráfego fluvial" (COSTA, 1982, p. 43). Dessa forma, se a produção de café da região tinha que ser escoada quase que exclusivamente por Santa Leopoldina, com o desenvolvimento do sistema rodoviário a partir dos anos 1920, parte dessa região começou a escoar o café por Colatina, onde desde 1906 já havia chegado a Estrada de Ferro Vitória à Minas (CAMPOS JÚNIOR, 2004).

A detenção do monopólio fluvial do transporte não era uma condição definitiva, mas nas décadas da sua ocorrência possibilitou a um pequeno grupo de comerciantes uma acumulação extraordinária. Após sua perda, a decadência comercial de Santa Leopoldina ocorreu de forma rápida e também foi agravada pela crise de 1929, quando os preços do café sofreram intensa desvalorização.

As maiores casas comerciais fecharam as portas. Como exemplo, a Vervloet e Cia, a maior de todas, permaneceu somente com o estabelecimento comercial do município de Santa Teresa, onde em 1932 o proprietário abriu a Cia Nacional do Comércio de Café, uma empresa exportadora. Em 1939 foi aberta uma filial dessa empresa na capital do Estado, mas em 1943 todas as atividades comerciais da família foram encerradas (DI FRANCESCO, 2005).

De forma geral, não se tem informações precisas sobre o encerramento das atividades das grandes casas comerciais dos tempos áureos de Santa Leopoldina. 
O que se verifica é que esses comerciantes encerraram suas casas comerciais e não tiveram destaque em outra atividade econômica. A Cia de Viação Geral, explorou por dez anos a estrada de Santa Leopoldina à Santa Teresa, mas também não há informação sobre o encerramento da sociedade.

Apesar do declínio comercial de Santa Leopoldina, os agricultores e a produção de café não foram afetados. A produção de café permaneceu com as mesmas características dos anos iniciais da criação do núcleo colonial, ou seja, cultivada em pequenas propriedades, dispondo da utilização de poucos recursos técnicos, assentada na mão de obra familiar como relação de trabalho predominante e subordinada ao comércio.

A desvalorização dos preços do café decorrentes da crise de 1929, não levou ao abandono da atividade e também afetava pouco a vida dos agricultores, majoritariamente familiares. Produzindo diretamente a maioria dos meios necessários à sua sobrevivência, a crise dos preços do café representava uma retração no consumo de mercadorias que não eram fundamentais, pois

a unidade produtora dependia muito pouco do café para sua subsistência, pois produzia a parte fundamental dos produtos básicos de alimentação e poderia alterar hábitos de consumo com a substituição de produtos comprados no mercado por outros de sua própria produção (ROCHA; MORANDI, 1991, p.50).

O que modificou nas propriedades foi a apropriação da sua área interna, sobretudo as de ocupação mais antiga. Devido a quase ausência de recursos técnicos, principalmente em uma região de solos rasos, com baixa fertilidade e com declividade acentuada, em menos de duas décadas os cafezais tornavam-se improdutivos. Assim ocorrido, abandonava-se o cafezal velho que era tomado por pastagens naturais, desmatava-se uma nova área da propriedade para o plantio de uma nova lavoura de café. Tratava-se da produção e reprodução do tradicional ciclo da agricultura capixaba, "mata-café-pastagens", o qual era

determinado, por uma lado, pela grande disponibilidade de terras que garantia à cafeicultura áreas virgens e férteis para sua reposição e ampliação, e, por outro lado, pelos métodos arcaicos e depredadores utilizados na lavoura cafeeira, que exauriam com grande rapidez os elementos orgânicos e a fertilidade natural do solo, tornando-o pouco apto a novos plantios. Isso, sem dúvida, constituiu um fator natural de expansão da pecuária, uma vez que a atividade, diante do esgotamento do solo, 
apresentava-se praticamente como a única alternativa de substituição (ROCHA; MORANDI, 1991, p.68).

Assim seguia-se reproduzindo esse ciclo, mata-café-pastagem, enquanto a fronteira interna da propriedade permitisse. Encerrada a fronteira interna, buscavase a aquisição de uma nova propriedade, até quando a fronteira agrícola estadual também permitisse.

\subsection{Transformações estruturais do Espírito Santo e suas manifestações em Santa Maria de Jetibá: crise da estrutura produtiva, erradicação dos cafezais, modernização da agricultura e industrialização da Grande Vitória}

A estrutura produtiva constituída no Espírito Santo a partir da política de criação de colônias e da imigração estrangeira, ou seja, baseada no trabalho familiar, na pequena propriedade e no cultivo do café com o emprego limitado de recursos técnicos, permaneceu sendo reproduzida de forma predominante até os anos 1960 . Isso significa que da introdução da cafeicultura na primeira metade do século XIX até os anos 1960, o que alterou foram as relações de trabalho e a dimensão da propriedade, uma vez que o escravo foi substituído pela mão de obra familiar e uma boa parte das fazendas foi fragmentada em pequenas propriedades. No entanto, os recursos técnicos e o produto principal permaneceram os mesmos, sem se vislumbrar outras alternativas que efetivamente diversificassem a economia estadual.

No entanto, essa estrutura produtiva dependia da disponibilidade de uma terra virgem, apta ao cultivo do café, para continuar se reproduzindo. Na medida em que as terras vão sendo apropriadas e ocupadas produtivamente, essa terra virgem vai se tornando escassa até inviabilizar a reprodução da estrutura produtiva capixaba. Quando chegou esse momento, iniciou-se a crise da estrutura produtiva, cujos contornos foram ampliados pela intensa adesão à política federal de erradicação dos cafezais, implementada no Espírito Santo ao longo dos anos 1960.

Alterou-se a estrutura produtiva pretérita sem substituí-la de imediato por outra forma de organizar a produção, uma vez que a modernização da agricultura se iniciou somente nos anos 1970. Tardia mas em velocidade acentuada, a 
modernização ocorreu quase paralelamente a industrialização do estado, marcada pela instalação de projetos de grande impacto.

Se no campo havia um forte movimento de expulsão da população, acentuado a partir da erradicação, na região da Grande vitória havia um movimento atrativo, decorrente da oferta de postos de trabalho relacionados à construção das obras dos "Grandes Projetos Industriais". Resultado: ocorreu a industrialização e a urbanização do Espírito Santo, com forte concentração populacional na região da Grande Vitória.

Anteriormente a essas mudanças estruturais grande parte da população era rural, cuja produção direta dos meios de vida ainda era importante no processo de reprodução socioeconômica da família. Com a urbanização, esse quadro se altera e grande parte da população torna-se consumidora de alimentos, ampliando o

mercado para esses produtos. É no âmbito dessas mudanças estruturais que a produção de hortaliças e ovos com fins comerciais emerge e se expande em Santa Maria de Jetibá.

\subsubsection{Crise da estrutura produtiva e seus limites de reprodução}

A estrutura produtiva em questão apresentava capacidade reduzida de geração de excedentes em função, sobretudo, de dois fatores. O primeiro se refere às relações de trabalho, pois predominando o trabalho familiar, praticamente não havia no âmbito da produção a exploração do trabalho de outrem. A produção de café estava restringida à capacidade de trabalho da família. Nas demais regiões produtoras, sob diferentes relações de trabalho, a produção de café era realizada explorando o trabalho alheio e, oportunamente, gerava maior valorização do capital.

O segundo fator refere-se ao desprezível padrão tecnológico da cafeicultura, que associado aos baixos níveis de fertilidade natural dos solos, conferiam ao trabalho menor produtividade. Dessa forma, o Espírito Santo destacava-se por obter patamares inferiores de produtividade e qualidade do café, quando comparado com os demais estados produtores.

Em que pese a baixa capacidade acumulativa verificada na estrutura produtiva da agricultura no Espírito Santo, tratava-se de uma realidade singular no país. Baseado nos dados do Recenseamento do Brasil de 1920, Buffon (1992) afirma que "quando confrontada com a de outros estados, ou mesmo com a do conjunto do 
país, a realidade capixaba resulta como algo único, sem paralelo na economia brasileira da época" (p. 136).

A singularidade pode ser verificada nos indicadores da tabela 4 , os quais revelam que em 1920 o número de propriedade do Espírito Santo representava 3,2\% do total país e que mesmo ocupando apenas 0,7\% da área agrícola nacional, eram responsáveis por $3,4 \%$ da área cultivada do país. A expressividade da participação da área cultivada do Espírito Santo significa que nesse estado o uso produtivo da terra era bem superior ao do país.

Acrescente-se também que $17,5 \%$ da área total das propriedades do estado eram cultivadas, conferindo-Ihe o maior percentual nacional. Além disso a área média das propriedades rurais capixabas (61ha) era 4,4 vezes menor que a média do país (272,3ha).

Tabela 4

Espírito Santo: indicadores das propriedades rurais

\begin{tabular}{|c|c|c|}
\hline Descritores & 1920 & 1940 \\
\hline Número de propriedades rurais do Espírito Santo & 20.941 & 41.919 \\
\hline Área das propriedades rurais do Espírito Santo (ha) & 1.279 .699 & 1.988 .231 \\
\hline Área média das propriedades rurais do Espírito Santo (ha) & 61 & 47 \\
\hline $\begin{array}{l}\text { Participação do número de propriedades rurais do Espírito Santo } \\
\text { no total país }\end{array}$ & $3,2 \%$ & $2,2 \%$ \\
\hline $\begin{array}{l}\text { Participação da área das propriedades rurais do Espírito Santo } \\
\text { no total país }\end{array}$ & $0,7 \%$ & $1,0 \%$ \\
\hline Participação da área cultivada do Espírito Santo no total do país & $3,4 \%$ & $3,0 \%$ \\
\hline $\begin{array}{l}\text { Percentual da área cultivada das propriedades rurais do Espírito } \\
\text { Santo }\end{array}$ & $17,5 \%$ & $28,4 \%$ \\
\hline $\begin{array}{l}\text { Participação do valor total das terras (terra mais máquinas e } \\
\text { benfeitorias) nas propriedades rurais do Espírito Santo no total do } \\
\text { país }\end{array}$ & $1,7 \%$ & $1,5 \%$ \\
\hline $\begin{array}{l}\text { Participação do valor somente da terra das propriedades rurais } \\
\text { do Espírito Santo no total do país }\end{array}$ & $1,1 \%$ & $1,4 \%$ \\
\hline $\begin{array}{l}\text { Participação do valor das máquinas e benfeitorias das } \\
\text { propriedades rurais do Espírito Santo no total do país }\end{array}$ & $4,3 \%$ & $2,0 \%$ \\
\hline $\begin{array}{l}\text { Participação do valor somente da terra das propriedades rurais } \\
\text { do Espírito Santo no valor total das terras (terra mais máquinas e } \\
\text { benfeitorias) }\end{array}$ & $50,7 \%$ & $69,1 \%$ \\
\hline $\begin{array}{l}\text { Fonte: Brasil, 1923; IBGE/Censo Agrícola, } 1951 . \\
\text { Elaboração: BERGAMIN, M, C. }\end{array}$ & & \\
\hline
\end{tabular}

Ao se considerar o valor total das terras (terra mais máquinas e benfeitorias) em 1920, a participação do Estado era de 1,7\% no total do país, mas quando se 
separa a terra das máquinas e benfeitorias, a participação da primeira é de somente $1,1 \%$, enquanto da segunda é de $4,3 \%$. Nessa época, havia equivalência na composição do valor total das terras do Espírito Santo, de forma que as máquinas e benfeitorias representavam 49,3\% e a terra 50,7\%. Em nenhuma unidade da federação a participação das máquinas e benfeitorias ultrapassava 35\% (BUFFON, 1992), pois a

\footnotetext{
elevada densidade de trabalho morto incorporado por hectare não resulta de outro motivo senão da intensiva aplicação de trabalho familiar nos estabelecimentos rurais do Espírito Santo, estabelecimento cujo tamanho e cultivo estavam dimensionados para 0 atendimento das necessidades mínimas de cada família (BUFFON, 1992, p. 140 e 141).
}

Depreende-se a partir dos dados de 1920, que no espaço rural do Espírito Santo, havia um uso produtivo da terra bem mais elevado quando comparado com o país. Além da moradia, eram construídas instalações para armazenar a produção, guardar instrumentos de trabalho, abrigar criações e animais, além de engenhos para moagem da cana para produção de açúcar, moinhos movidos a água para o beneficiamento de cereais, entre outros. Eram instalações e benfeitorias destinadas, sobretudo, à produção direta dos meios de vida da família.

Predominando agricultores assentados em bases familiares de produção, ou seja, em relações não capitalistas de produção, a terra constituía-se em meio de trabalho e não de negócio. Nessas condições, os interesses especulativos pela ampliação da propriedade da terra eram bem menores e, por essa razão, o agricultor investia mais em benfeitorias e máquinas para produzir do que na incorporação de mais terras que não tivesse o intuito de ser utilizadas. Há uma grande diferença entre terra de trabalho e de negócio, conforme será discutido no capítulo 4. Acrescente-se também que nessa época o mercado de terras no estado ainda estava em processo de formação, uma vez que a área ocupada pelos propriedades rurais representava somente $28,6 \%$ da área do estado (BRASIL, 1920).

Os dados de 1940 mostram algumas modificações mas que não interferem nas características que singularizavam a realidade capixaba. No intervalo de vinte anos as propriedades rurais aumentaram consideravelmente, tanto em número quanto em área, de forma que passaram a representar $46,4 \%$ da área do estado (IBGE, 1951). Isso porque em 1928 foi inaugurada a ponte sobre o rio Doce em 
Colatina e, oportunamente, abriu-se a fronteira agrícola em direção ao norte do estado. "O significado da ponte ia além da simples função de possibilitar a transposição de um rio; abria novas possibilidades à reprodução da estrutura produtiva vigente - funcionava como um "oxigênio" novo à pequena produção" (CAMPOS JÚNIOR, 2004, p.24).

Verifica-se também que nos anos 1940 a participação dos valores das terras, máquinas e investimentos foi um pouco alterada, aumentado a valorização da terra. O percentual de área cultivada das propriedades rurais elevou-se para $28,4 \%$, um indicador três vezes superior à média nacional $(9,5 \%)$ (IBGE, 1951). Houve também redução no tamanho médios das propriedades rurais, indicando que a incorporação de novas áreas ocorria predominantemente por meio de pequenas propriedades.

No entanto, são mudanças que não alteraram as relações de trabalho, os recursos técnicos, a estrutura fundiária e a predominância da cafeicultura. Dessa forma, os aspectos fundamentais da estrutura produtiva permaneceram. Apesar da crise de 1929 e a consequente desvalorização dos preços do café, o que se constata é que não houve abandono da atividade por parte dos agricultores capixabas; pelo contrário, entre 1920 e 1940, o número de cafeeiros mais que dobrou, elevando-se de 114.583.122 pés para 257.272.755 (BRASIL, 1923; IBGE, 1951).

Isso significa que a incorporação de novas áreas baseou-se também no cultivo do café e assim segue até os anos 1960, quando o número de cafeeiros chega a 447.645.103 pés plantados no Espírito Santo (IBGE, 1969). Entre 1940 e 1960, foi o período de maior expansão da cafeicultura decorrente da elevação dos preços do produto. Se em 1945 o valor de uma saca de café de $60 \mathrm{~kg}$ era $16,18 \mathrm{US} \$$, em 1954 elevou-se para 86,83US\$ (ROCHA; MORANDI, 1991), ou seja, em dez anos o preço foi ampliado em mais de 4 vezes.

Apesar de toda a expansão da cafeicultura e do auge da atividade nos anos 1960, a reprodução da estrutura produtiva, que foi predominante por quase um século, começou a encontrar limites desde a década de 1940. Isso porque inicia-se o fechamento da fronteira agrícola para o café no Estado, primeiro na região sul, posteriormente na região central e por último na região norte, onde havia indisponibilidade natural de terras propícias ao cultivo do café. 
O esgotamento da estrutura produtiva torna-se evidente por meio da análise da taxa de crescimento do estoque de cafeeiros do Estado. Segundo Buffon (1992), essa taxa era de $4,1 \%$ a.a. entre $1920 / 1940$ e caiu para 2,2\% a.a. no período de 1950/1960. A queda maior ocorreu entre os cafeeiros novos, que em 1940/1950 cresceram $6,8 \%$ a.a., mas entre $1950 / 1960$ somente $0,2 \%$ a.a. A explicação para a queda da taxa de crescimento dos estoques de cafeeiros está relacionada à inexistência de novas áreas virgens que permitissem a reprodução do ciclo matacafé-pastagem. Encontra-se aí um dos limites para a reprodução de uma estrutura produtiva que dependia sempre uma terra nova para ser desmatada, onde se iniciaria um novo cultivo de café, que após tornar-se velho e improdutivo seria abandonado e tomado por pastagens.

\subsubsection{Erradicação dos cafezais: ampla adesão dos agricultores}

Se os preços do café vinham apresentando tendência de elevação conforme abordado, a partir de 1955 esse cenário se inverte e começa uma outra de tendência, mas de queda e manutenção de preços baixos até os anos 1970. Esse cenário de queda dos preços decorre do excesso de produção de café no mercado internacional, e os estoques nacionais não eram absorvidos nem internamente, nem externamente. Entre 1960 e 1968, o estoque excedente anual de café no país foi sempre superior a 52 milhões de sacas de 60,5kg (PANAGIDES, 1969).

Durante alguns anos o governo brasileiro sustentou artificialmente os preços do café por meio da aquisição dos estoques excedentes. No entanto, perante a crise de preços e do excesso de produção, nos anos 1960 o governo federal implementou uma nova política cafeeira, da qual o Grupo Executivo de Racionalização da Cafeicultura - GERCA, fazia parte. Em 1962 esse Grupo elaborou um plano diretor composto por três diretrizes básicas: "promoção da erradicação dos cafezais antieconômicos, diversificação das áreas erradicadas com outras culturas e renovação de parcela dos cafezais" (ROCHA; MORANDI, 1991, p. 52).

Dessas diretrizes a erradicação foi a que obteve mais êxito e por cada cafeeiro cortado o agricultor era indenizado pelo governo federal. Realizada em duas etapas, a primeira entre 1962 e 1963 e a segunda entre 1966 e 1967, a política de erradicação no Espírito Santo atingiu um número de cafeeiros bem superior à cota que Ihe fora estabelecida pelo GERCA. Em termos proporcionais o Espírito Santo foi 
o estado mais atingido pela erradicação, pois $53,8 \%$ dos cafeeiros e capixabas foram erradicados, os quais ocupavam $71,0 \%$ da área ocupada com a atividade. Em Minas Gerais, Paraná e São Paulo percentual de cafeeiros erradicados foi da ordem, respectivamente de $33,0 \%, 28,4 \%$ e $26,0 \%$, ou seja, bem inferiores em relação ao Espírito Santo (ROCHA; MORANDI,1991).

É importante ressaltar que embora em 1960 a produção de café do Espírito Santo tenha atingido o seu apogeu, sua contribuição com a produção nacional era de somente 6\% (IBGE, 1969). Em outras palavras, a produção de café do Espírito Santo contribuiu muito pouco para a formação dos estoques excedentes, mas, apesar disso, o Estado foi o mais afetado pela política de erradicação dos cafezais.

Ocorre que sempre houve uma contradição entre a importância do café para o Espírito e sua participação na produção nacional. Aproximadamente por um século a cafeicultura foi a principal atividade econômica do estado, mas sua produção no contexto nacional começou a ganhar mais importância somente a partir dos anos 1970, no pós-erradicação, quando passa a contribuir com 21,3\% (IBGE/Censo Agropecuário, 1970).

Além de ter sido, proporcionalmente, o Estado mais afetado pela erradicação, outro aspecto que chama atenção foi a destinação da área liberada pelos pés de café erradicados. Contrariando uma das diretrizes do GERCA que estabelecia a diversificação produtiva, o Espírito Santo foi o Estado que menos diversificou, pois a estimativa é de que $70,11 \%$ da área erradicada foi ocupada por pastagens, enquanto esse indicador em São Paulo foi de somente 27,0\% (tabela 5). A além disso, entre 1960 e 1970 a área ocupada pela pecuária mais que dobrou (IBGE/Censo Agropecuário, 1960 e 1970).

Considerando que além da cafeicultura ser a principal atividade econômica do Estado, era também a principal geradora de empregos. No auge da crise da cafeicultura, em 1960, o emprego do setor agrícola representava $68,1 \%$ da População Economicamente Ativa (PEA) e somente a cafeicultura empregava $80 \%$ da mão de obra agrícola (ROCHA; MORANDI,1991). Nessas circunstâncias,

A crise social gerada pela erradicação é o aspecto mais ressaltado e se expressou de forma dramática na substancial redução da renda e do emprego, o que provocou o empobrecimento econômico e um vigoroso processo de "expulsão" da população do campo para as áreas urbanas. 
Estima-se o desemprego de aproximadamente 60 mil pessoas, o que, considerando-se uma taxa média de dependência de 3 por 1, mostra ter sido afetado um total aproximado de 240 mil pessoas, sendo que boa parte migrou para as cidades (ROCHA; MORANDI,1991, p.57).

Tabela 5

Estimativa de reocupação das terras liberadas pela erradicação do café nos principais Estados produtores

\begin{tabular}{l|ccccc}
\hline $\begin{array}{l}\text { Cultura } \\
\text { substitutiva }\end{array}$ & \multicolumn{4}{|c}{ Área liberada (\%) } \\
\cline { 2 - 5 } & Espírito Santo & Paraná & São Paulo & Minas Gerais \\
\hline Pastagem & 70,11 & 40,40 & 27,00 & 66,50 \\
Algodão & 0,43 & 16,00 & 7,00 & - \\
Arroz & 0,12 & 1,80 & 17,00 & 1,60 \\
Café & 0,18 & - & - & 0,40 \\
Culturas anuais & - & 13,20 & - & - \\
Feijão & 1,77 & 4,80 & 2,00 & 7,50 \\
Mamona & 0,63 & 2,90 & 1,00 & - \\
Mandioca & 10,58 & 1,80 & 1,00 & 1,70 \\
Milho & 9,44 & 8,20 & 26,00 & 11,20 \\
Outras culturas & 2,37 & 10,90 & 10,00 & 4,60 \\
Total & 95,63 & 100 & 100 & 96,50 \\
\hline
\end{tabular}

Fonte: PANAGIDES, 1969 apud Instituto Brasileiro de Café, Relatório GERCA Programa de Diversificação Econômica do Estado: Paraná, São Paulo, Minas Gerais e Espírito Santo, 1965.

É inegável que a erradicação do café promoveu uma desestruturação socioeconômica sem precedentes na história do Espírito Santo e que se tal política não fosse implementada no Estado, a estrutura produtiva até então desenvolvida continuaria sendo reproduzida por mais alguns anos. No entanto, não se pode atribuir somente a essa política a responsabilidade pela grave crise que atravessou o Espírito Santo. Conforme assinala Buffon (1992), desde a década de 1940 o crescimento do estoque de cafeeiros já vinha apresentando tendência de queda em razão do início do fechamento da fronteira agrícola. A existência de uma fronteira agrícola interna ou externa à propriedade, era uma condição sine qua non à reprodução da estrutura produtiva.

Primeiramente a reprodução da estrutura produtiva foi comprometida pelo processo de fechamento da fronteira agrícola para o café e, em segundo lugar, para agravar essa situação, ocorreu uma ampla adesão por parte dos agricultores à política de erradicação. Se a reprodução da estrutura produtiva não estivesse comprometida, qual a razão para uma adesão tão ampla à erradicação? "Fosse a cafeicultura capixaba produtiva, competitiva e lucrativa no contexto nacional a 
erradicação não teria alcançado proporções tão marcantes como as verificadas no Espírito Santo" (BUFFON, 1992, p.195).

Além da intensidade da erradicação, outro aspecto que agravou a situação socioeconômica do Espírito Santo foi a ocupação de grande parte da área erradicada por pastagens em vez de se diversificar com culturas alimentares. Mesmo empregando poucos recursos técnicos, o manejo da cafeicultura demandava a realização de várias atividades (plantio, capinas, colheita, secagem etc.), ao contrário da pecuária que, desenvolvida de forma extensiva, é uma atividade com pouco potencial de absorção de mão de obra. Quando se compara a absorção de mão de obra por área e atividade, a pecuária absorvia somente 13,8 da capacidade da cafeicultura (PANAGIDES, 1969).

Em que pese todos impactos da erradicação, anteriormente à implementação dessa política já havia êxodo rural no Espírito Santo, pois "a agricultura, a longo prazo, apresentar-se-ia incapaz de crescer extensivamente e criar um ritmo prolongado de geração de emprego" (SOUZA FILHO, 1990, p.166). No Espírito Santo, a agricultura revelou tal incapacidade antes mesmo da erradicação, uma vez que a partir de 1940 a população rural já apresentava ritmo de crescimento inferior ao da população urbana (tabela 6).

\section{Tabela 6}

Espírito Santo: evolução da população rural e urbana (1940-1980)

\begin{tabular}{l|cccccc}
\hline Ano & Rural (no) & Urbana (no) & Total (nº) & Rural (\%) & Urbana (\%) \\
\hline 1940 & 593.099 & 157.008 & 750.107 & 79,1 & 20,9 \\
1950 & 666.627 & 194.935 & 861.562 & 77,4 & 22,6 \\
1960 & 799.478 & 370.075 & 1.169 .553 & 68,4 & 31,6 \\
1970 & 877.417 & 721.916 & 1.599 .333 & 54,9 & 45,1 \\
1980 & 729.926 & 1.293 .378 & 2.023 .340 & 36,1 & 63,9 \\
\hline
\end{tabular}

Fonte: IBGE/Censo Demográfico, 1940, 1950, 1960, 1970 e 1980.

Elaboração: BERGAMIN, M, C.

No entanto, essa tendência de crescimento do êxodo rural se intensificou extraordinariamente, primeiro com a erradicação nos anos 1960 e, posteriormente, em intensidade menor, com a modernização da agricultura na década de 1970. 


\subsubsection{Modernização da agricultura: um processo violento}

Com a crise da estrutura produtiva e a erradicação cafezais nos anos 1960, não ocorreu de imediato uma reestruturação da produção alterando a forma pretérita de produzir. As pastagens e as poucas culturas alimentares que substituíram o café não incorporaram progresso técnico de imediato. Essa mudança vai ocorrer somente na década de 1970, mais especificamente a partir de 1975 (Tabela 7), quando a modernização da agricultura capixaba começa a tomar maior ímpeto e se inicia o desenvolvimento de uma nova estrutura de produção. Entre o desmonte da estrutura produtiva anterior à erradicação e a modernização da agricultura, por quase uma década não ocorreu um processo de recomposição da estrutura pretérita que promovesse a sua substituição por uma nova forma de produzir.

Nessa perspectiva, o processo de modernização da agricultura no Espírito Santo não se constituiu em uma continuidade, por meio da transição da estrutura produtiva pretérita para uma nova. Além de iniciada alguns anos após uma crise e a erradicação dos cafezais, a modernização da agricultura ocorreu tardiamente no Espírito, mais especificamente na década seguinte às alterações da estrutura produtiva pretérita. Embora tardia, a modernização teve ritmo muito acelerado e dessa forma,

Não houve uma transição gradual da antiga para a nova estrutura, mas a destruição da base produtiva pretérita. É nisto que reside a particularidade da modernização agrícola no Espírito Santo, justificando seu estudo como um caso "sui generis" entre todos os estados brasileiros. A modernização atrasou-se, inicialmente, para, em um momento posterior, ser mais rápida e intensa (SOUZA FILHO, 1990, p.5).

Além de manifestar o caráter conservador da modernização da agricultura brasileira, como determinadas atividades, tipos de agricultores e regiões e de ser parcial ao não modernizar todas as etapas do processo produtivo, no Espírito Santo a modernização da agricultura foi cunhada por Souza Filho (1990) como "modernização violenta". Tal denominação se deve a intensidade e o ritmo em que ocorreram as transformações socioeconômicas no campo após um período de forte estagnação.

Conforme pode ser verificado na tabela 7, a modernização da agricultura no Espírito Santo foi iniciada tardiamente, uma vez que até 1970 os indicadores de incorporação de progresso técnico do estado eram bastante inferiores à média nacional. Essa mudança tecnológica vai ocorrer somente a partir de 1975 quando a 
modernização se intensifica no Estado e os indicadores começam a superar a média do país. Nessa época o uso de fertilizantes e defensivos já era superior à média nacional, mas a área média explorada por trator ainda não.

Tabela 7

Brasil e Espírito Santo: Indicadores de incorporação de inovações técnicas pelas propriedades rurais (1960 a 1985)

\begin{tabular}{|c|c|c|c|c|c|c|c|c|c|c|}
\hline \multirow{2}{*}{ Indicadores } & \multicolumn{2}{|c|}{1960} & \multicolumn{2}{|c|}{1970} & \multicolumn{2}{|c|}{1975} & \multicolumn{2}{|c|}{1980} & \multicolumn{2}{|c|}{1985} \\
\hline & BR & ES & BR & ES & BR & ES & BR & ES & BR & ES \\
\hline $\begin{array}{l}\text { Número } \quad \text { de } \\
\text { tratores }\end{array}$ & 61345 & 508 & 165870 & 1131 & 323113 & 1940 & 545205 & 5328 & 665280 & 9079 \\
\hline $\begin{array}{ll}\text { Área média } & \text { mexplorada por } \\
\text { trator (ha) } & \end{array}$ & 4073 & 7239 & 1773 & 3323 & 1002 & 1997 & 669 & 712 & 563 & 422 \\
\hline $\begin{array}{l}\text { Uso de } \\
\text { fertilizantes por } \\
\text { propriedade (\%) }\end{array}$ & 13,19 & 5,31 & 15,43 & 11,22 & 22,33 & 23,90 & 32,17 & 56,16 & 31,63 & 63,12 \\
\hline $\begin{array}{l}\text { Uso de } \\
\text { defensivos por } \\
\text { propriedade }(\%)\end{array}$ & - & - & - & - & 51,15 & 74,54 & 60,32 & 81,78 & 54,97 & 69,48 \\
\hline
\end{tabular}

Fonte: Censos Agropecuários/ES -1960, 1970, 1975, 1980 e 1985.

Elaboração: BERGAMIN, M, C.

- indicador inexistente

Baseado, então, nesses indicadores, optou-se por analisar o período entre 1960 e 1985, porque esse recorte temporal revela tanto a fase da transição da base técnica, quanto o momento de maior intensidade na incorporação de tecnologias, ou seja, quando se alterou a base técnica e se reestruturou a forma de produzir no campo, uma vez que o

\footnotetext{
Instrumento primordial para a modernização da agricultura foi o amplo emprego de máquinas, insumo químicos e biotecnológicos, fornecidos pela atividade industrial, provocando notáveis metamorfoses, seja na atividade humana voltada para a transformação da natureza, que sofreu intenso processo de divisão do trabalho, seja na terra, transformada cada dia mais em terra-matéria em terra-mercadoria (ELIAS, 2003, p. 60).
}

A partir de 1985 a agricultura capixaba segue-se modernizando e incorporando novas tecnologias, mas o auge da sua modernização, o momento de "notáveis metamorfoses" vai se dar entre 1975 e 1980, quando ocorre intensa incorporação de progresso técnico. No entanto, essa intensidade vai ser afetada pela crise da política de crédito, cujo volume investido sofre vertiginosa retração. Em 1985 já se constata uma redução no ritmo da modernização capixaba, pois as décadas de 1970 e 1980 consistem em um período que vai do auge à redução drástica do crédito rural investido, cujos reflexos manifestam-se no Espírito Santo, pois 
O crédito rural concedido no auge de sua expansão, em 1976, ascendeu a mais de 20 bilhões de dólares, um valor quase equivalente ao Produto Interno Bruto da Agricultura de então. O mesmo indicador (crédito rural concedido) decresceu abruptamente no final da década de 1980 para níveis equivalentes a cerca de $20 \%$ do PIB do setor agrícola no período (DELGADO, 2002, p. 222).

Houve redução da oferta de crédito rural e mudanças nas condições de financiamento, pois o Estado não foi capaz de sustentar por muitos anos a política financeira do Sistema Nacional de Crédito Rural (SNCR) que concedia empréstimos com taxas de juros negativas. Criado nos anos 1960, o SNCR foi o carro-chefe da modernização da agricultura brasileira e um importante instrumento da modernização da agricultura pois ofereceu crédito farto e barato, que subsidiaram a incorporação de um conjunto de inovações técnicas.

Por sua vez, é importante contextualizar que quando a modernização se iniciou no Estado, a internalização do departamento produtor de bens de capital (D1) já havia sido concluída no país. Isso significa que o processo de modernização no Estado não dependeu da importação de máquinas e insumos agrícolas, pois segundo Silva (2003), em 1970 a produção interna de tratores era responsável por $99 \%$ da oferta nacional. $\mathrm{O}$ momento em que se iniciou a modernização da agricultura no Espírito Santo, mesmo com a redução do volume de crédito rural nos anos 1980, favoreceu a intensidade e a rapidez da incorporação de progresso técnico decorrente da internalização do D1.

Outro aspecto importante da modernização da agricultura no Espírito Santo, é que embora tenha sido conservadora e violenta, na distribuição do crédito rural no estado, as propriedades rurais com área inferior a 50 ha receberam um percentual de incentivos creditícios mais elevado que seus congêneres em termos nacionais. Conforme pode ser verificado na tabela 8 , o percentual de crédito destinado a essas propriedades no Espírito Santo foi superior ao do país, com destaque para 1985, quando foi quase $100 \%$ maior. A exceção recai somente para 1970 , quando a modernização da agricultura ainda não havia tomado ímpeto no Espírito Santo. 
Tabela 8

\begin{tabular}{|c|c|c|c|c|c|c|}
\hline \multicolumn{7}{|c|}{$\begin{array}{c}\text { Brasil e Espírito Santo: Evolução do percentual de propriedades rurais inferiores a } 50 \\
\text { ha e sua participação na distribuição do crédito rural }\end{array}$} \\
\hline \multirow{3}{*}{ Anos $^{*}$} & \multicolumn{2}{|c|}{$\begin{array}{l}\text { Crédito rural para propriedades } \\
\text { rurais inferiores a } 50 \text { ha (\%) }\end{array}$} & \multicolumn{4}{|c|}{ Propriedades rurais inferiores a 50 ha (\%) } \\
\hline & \multirow{2}{*}{ Brasil } & \multirow{2}{*}{ Espírito Santo } & \multicolumn{2}{|c|}{ Brasil } & \multicolumn{2}{|c|}{ Espírito Santo } \\
\hline & & & №. & Área & №. & Área \\
\hline 1970 & 26,8 & 23,0 & 83,5 & 15,9 & 72,8 & 28,4 \\
\hline 1975 & 41,3 & 61,2 & 83,0 & 13,7 & 69,2 & 23,4 \\
\hline 1980 & 40,8 & 55,5 & 81,8 & 12,6 & 71,2 & 22,8 \\
\hline 1985 & 30,9 & 58,5 & 82,5 & 13,2 & 74,9 & 24,6 \\
\hline
\end{tabular}

Fonte: IBGE/Censos Agropecuários, 1970, 1975, 1980 e 1985.

Elaboração: BERGAMIN, M, C.

*Os anos 1960 não foram incluídos decorrente da indisponibilidade de dados sobre valores de financiamentos.

Acerca da posição do Espírito Santo em relação ao elevado percentual de crédito rural concedido às propriedades rurais inferiores a 50 ha, duas considerações são importantes. A primeira é que face a estrutura fundiária do Estado ser uma das menos concentradas do país, contribui para que as propriedades rurais menores sejam mais beneficiadas, uma vez que as grandes propriedades rurais são bem menos representativas que à média nacional, tanto numericamente quanto em área ocupada.

A segunda consideração diz respeito ao fato da cafeicultura, a principal atividade agrícola do Estado (tabela 9), ser uma commodity e cultivada em pequenas propriedades rurais. Como o café é uma cultura agroindustrializável e voltada prioritariamente para o mercado externo, a atividade foi contemplada pela modernização e, oportunamente, as pequenas est propriedades tiveram mais facilidades para ter acesso ao crédito rural.

Isso fica muito evidente em 1985, quando a cafeicultura atinge maior produção e área ocupada até então e, ao mesmo tempo, o percentual de crédito destinado às propriedades inferiores a 50 ha quase dobrou em relação ao país (tabela 8). A cafeicultura foi retomada a partir de 1976, em novas bases técnicas e contou com incentivos creditícios, contribuindo diretamente para aumentar o percentual de crédito destinado às propriedades rurais em questão.

Isso não quer dizer que o processo de modernização da agricultura no estado não tenha sido conservador. Pelo contrário, o avanço do capitalismo no campo promoveu concentração fundiária, êxodo rural, expansão do trabalho assalariado e 
se desenvolveu de forma diferenciada entre determinados agricultores, tipos de culturas e regiões. No entanto, não se pode perder de vista que aqueles agricultores, tipos culturas e regiões que não foram incorporadas pela modernização, na medida em que oferecessem possibilidades de acumulação e valorização para o capital industrial, sua base técnica seria modificada. Nessa perspectiva,

\begin{abstract}
Se as formas tradicionais de produção foram mobilizadas em certo momento para apoiar o esforço de acumulação, elas mesmas estavam condenadas a serem transformadas, na medida em que o setor agrícola se transformasse num campo de valorização do capital industrial (SORJ, POMPERMAYER e CORADINI, 1982, p.10).
\end{abstract}

No entanto, as principais atividades agropecuárias beneficiadas no âmbito da modernização e que foram contempladas com políticas específicas são exatamente aquelas agroindustrializáveis ou destinadas prioritariamente ao mercado externo, como café, cacau, cana-de-açúcar e eucalipto, além da pecuária. Naquele momento eram as culturas ou atividades que ofereciam maiores possibilidades de acumulação para o capital industrial, mesmo que a cafeicultura fosse cultivada em pequenas propriedades rurais e com utilização de mão de obra familiar.

Primeiramente dois planos do GERCA (Plano de Emergência e Plano de Renovação e Revigoramento dos Cafezais) foram destinados à cafeicultura a partir de 1970, os quais tinham como intuito estimular o desenvolvimento da atividade em modernas bases de produção. Para tanto,

\footnotetext{
Foram concedidos financiamentos a taxa de juros menores, para todas as finalidades, inclusive liberação de recursos para ampliar ou implantar instalações de preparo e armazenamento de café, bem como construção de estradas vicinais e eletrificação rural (SOUZA FILHO, 1990, p.104).
}

No entanto, a retomada da cafeicultura vai ocorrer somente a partir de 1976, quando ocorre elevação considerável dos preços do café6 no mercado internacional, em patamares bem superiores ao do auge da atividade nos anos 1960. A retomada e a expansão da cultura vão se dar em novas bases técnicas, relativamente modernas, sobretudo na nova variedade introduzida, o conillon. Essa variedade é mais adequada às condições climáticas do Estado, onde predominam temperaturas

\footnotetext{
${ }^{6}$ Em 1975 as principais regiões produtoras de café do país foram afetadas por uma forte geada que ocasionou uma importante queda na produção e consequentemente os preços se elevaram.
} 
elevadas e mais resistente e produtiva que o café arábica, a variedade usada anteriormente.

Isso não significa que a modernização ocorreu de forma generalizada. Houve sim uma incorporação de progresso técnico em patamares bem elevados em relação à estrutura pretérita, mas de forma parcial. A mecanização da atividade vai se restringir à preparação dos solos, mas a colheita permanece manual e as inovações físico-químicas nem sempre são incorporadas na intensidade necessária. É importante ressaltar que mesmo se modernizando, a cafeicultura continuou como principal atividade agrícola (tabela 9), predominantemente assentada no trabalho familiar e cultivada em pequenas propriedades rurais.

Tabela 9

Espírito Santo: evolução de algumas atividades agrícolas (1960-1985)

\begin{tabular}{|c|c|c|c|c|c|c|c|c|c|c|}
\hline \multirow[b]{2}{*}{ Cultura } & \multicolumn{2}{|c|}{1960} & \multicolumn{2}{|c|}{1970} & \multicolumn{2}{|c|}{1975} & \multicolumn{2}{|c|}{1980} & \multicolumn{2}{|c|}{1985} \\
\hline & $\begin{array}{l}\text { Área } \\
\text { (ha) }\end{array}$ & Produção & $\begin{array}{l}\text { Área } \\
\text { (ha) }\end{array}$ & Produção & $\begin{array}{r}\text { Área } \\
\text { (ha) }\end{array}$ & Produção & $\begin{array}{l}\text { Área } \\
\text { (ha) }\end{array}$ & Produção & $\begin{array}{l}\text { Área } \\
\text { (ha) }\end{array}$ & Produção \\
\hline Café1 & 328255 & 243425 & 190586 & 174496 & 187122 & 108484 & 275496 & 283759 & 443030 & 478842 \\
\hline Arroz ${ }^{1}$ & 36252 & 26692 & 50813 & 44201 & 43148 & 37478 & 31317 & 34996 & 45849 & 67916 \\
\hline Banana $^{2}$ & 25129 & 13767 & 26586 & 14937 & 15546 & 15033 & 18972 & 17807 & 22695 & 23273 \\
\hline Cacau $^{1}$ & 12782 & 3772 & 20126 & 5889 & 21997 & 9472 & 15540 & 11985 & 20226 & 12073 \\
\hline Cana $^{1}$ & 19147 & 367224 & 20779 & 455499 & 13734 & 499643 & 18475 & 727934 & 42829 & 2410644 \\
\hline Feijão ${ }^{1}$ & 49153 & 15879 & 68930 & 20946 & 67127 & 22205 & 62574 & 24580 & 106147 & 43729 \\
\hline Mandioca ${ }^{1}$ & 24768 & 151884 & 31840 & 249556 & 22552 & 185050 & 17123 & 200241 & 33634 & 325917 \\
\hline Milho' & 152736 & 119794 & 184981 & 162204 & 150649 & 152071 & 133988 & 137001 & 142925 & 161617 \\
\hline $\begin{array}{l}\text { Florestas } \\
\text { plantadas }\end{array}$ & - & - & 22119 & - & 98388 & - & 143148 & - & 156785 & - \\
\hline Eucalipto $^{3}$ & - & - & - & 24415 & - & 153839 & - & 202300 & - & 165477 \\
\hline
\end{tabular}

Em relação ao cacau, a cultura se desenvolveu principalmente o vale do rio Doce e sempre ocupou uma área pequena. Antes mesmo da modernização da agricultura, foi criada em 1957 a Comissão Executiva do Plano da Lavoura Cacaueira - CEPLAC, que tinha como objetivo executar um plano para a modernizar a atividade. Houve expansão dos cultivos (tabela 9), mas sem nenhum ganho de produtividade.

No âmbito da modernização e considerando o desempenho da atividade, nos anos 1970 foi implementado o Programa para Recuperação da Lavoura Cacaueira - PROCACAU. Dispondo de programa específico e facilidades na obtenção de crédito, a cultura obteve elevados ganhos de produtividade e produção, ampliando 
muito pouco a área cultivada. Apesar de todos os incentivos destinados ao cultivo do cacau, atividade não se expandiu no estado.

Por sua vez, a silvicultura e a cana-de açúcar são duas culturas que também se destacam no âmbito da modernização, mas que se diferenciam pelas relações de trabalho empregadas e pela dimensão dos cultivos. Ambas culturas, de forma predominante, incorporaram plenamente as inovações tecnológicas (exceto a colheita da cana que permaneceu manual), usaram mão de obra assalariada e foram cultivadas em médias e grandes propriedades. São exemplos que se encaixam perfeitamente na modernização conservadora brasileira no que tange à destinação do produto, a incorporação de progresso técnico, as relações de trabalho e a dimensão das propriedades.

São culturas que se expandiram devido a instalação de empreendimentos agroindustriais no Estado, como a Aracruz Celulose em 1978 e várias alcooleiras a partir de 1979 no âmbito do Programa Nacional de Álcool - Proálcool. Conforme abordado, haviam políticas específicas para algumas culturas e quando foram instalados os projetos agroindustriais em questão, iniciava-se uma tendência de redução do volume de crédito concedidos via SNCR. A partir dos anos 1980,

\begin{abstract}
A política de subsídios tornou-se mais seletiva, priorizando determinadas cadeias agroindustriais, como a tritícola e a sulcroalcooleira; [...] essa seletividade ocorreu em detrimento das políticas públicas convencionais de crédito e preços mínimos, que apesar de conservadoras, eram ainda mais abrangentes (LEITE, 2001, p. 60 e 61).
\end{abstract}

Diretamente beneficiados pela seletividade da política de subsídios e pela facilidade de acesso ao crédito rural, os cultivos de cana-de-açúcar foram consideravelmente ampliados nos anos 1980 (tabela 9. Concentrada anteriormente na região sul do estado, onde já havia uma usina instalada a várias décadas no município de Itapemirim, a produção de cana-de-açúcar expandiu-se na região norte nos anos de 1980. No âmbito do Proálcool, foram instaladas seis destilarias na região norte, onde predominam áreas planas e favoráveis à mecanização. Nesse contexto,

um dos primeiros efeitos do Proálcool para a agricultura capixaba foi o direcionamento prioritário do crédito agrícola para a produção de cana-deaçúcar em detrimento da cultura agroalimentar. A cana estimulou muitos produtores a abandonar outras culturas e foi priorizada por representar uma cultura sem riscos, uma vez que havia demanda para o produto e, portanto, garantia de sua venda (VALADÃO, 1999, p.55). 
Na região norte também se concentraram os cultivos de eucalipto, que se expandiram vertiginosamente a partir de 1975 (tabela 9), formando grandes extensões de florestas homogêneas, conhecidas como o "deserto verde". A atividade foi amparada por uma política de isenção fiscal, estabelecida pela Lei 5.106 de 1966, que previa o abatimento de $50 \%$ do imposto de renda para quem realizasse atividades de reflorestamento. Em 1985, dos 165.477 .000 pés de eucalipto existentes no estado, 120.904 .000 foram plantados com aplicação de incentivos fiscais (IBGE/Censo Agropecuário, 1985).

Por ser uma cultura agroindustrializável e destinada ao mercado externo, o cultivo de eucalipto também teve facilidade de acesso ao crédito rural subsidiado. $O$ Espírito Santo tornou-se um dos maiores produtores nacionais de eucalipto e entre 1983 e 1982, foram concedidos para o Estado 19,3\% do volume de crédito rural destinado as atividades de reflorestamento (SOUZA FILHO, 1990).

A produção de cana-de-açúcar e de eucalipto concentrou-se em poucos municípios, localizados sobretudo na região norte do Estado, que destinaram grande parte da área agrícola para essas duas culturas. Em 1985 os municípios que se destacavam como maiores produtores de eucalipto eram São Mateus, Aracruz e Conceição da Barra e de cana-de-açúcar eram Itapemirim (único localizado no sul do estado), Linhares, São Mateus e Conceição da Barra (IBGE/Censo Agropecuário, 1985).

Essas atividades alteraram profundamente a base espacial da região, principalmente nos municípios onde se concentraram e, oportunamente, desencadearam intenso processo de êxodo rural e de concentração fundiária, cujo índice de Gini, a partir de 1985 passou a ser superior a 0,800 na maioria deles (BERGAMIM, 2004). Além de serem atividades com reduzida capacidade de absorção de mão de obra devido ao nível de mecanização empregado, no caso do eucalipto, essa situação ainda foi agravada pelo extenso tempo de produção da cultura.

Por sua vez, embora não se tenha destinado políticas específicas para as culturas alimentares, a rizicultura contou com um programa específico nos anos 1980, denominado Programa Nacional de Recuperação de Várzeas Irrigáveis PRÓVARZEAS. Além dos recursos do SNCR, segundo Souza Filho (1990) o Espírito 
Santo foi o único Estado a contar com aporte financeiro do Kreditanstalt Fuer Wiederaufban (KFW). Como resultado do programa entre os anos 1980 e 1985 a produção de arroz quase dobrou (tabela 10).

Dois outros cultivos alimentares também tiveram aumento de produção: o feijão e a mandioca. Essas culturas sempre estiveram muito mais voltadas à produção direta dos meios de vida dos agricultores familiares que destinavam ao comércio somente o excedente produtivo. Entre 1980 e 1985, em apenas cinco anos a produção de feijão foi ampliada em $78 \%$ e a de mandioca em $63 \%$ (tabela 9). A expansão do feijão ocorreu devido a introdução de cultivos irrigados na Baixada Espírito-Santense e a da mandioca foi estimulada em decorrência de um projeto para instalação de uma agroindústria que produziria pellets, mas que não se efetivou (SOUZA FILHO, 1990).

Os cultivos comerciais de hortaliças também se expandiram consideravelmente no âmbito da modernização, concentrados na região serrana do estado, onde as temperaturas mais amenas favorecem o desenvolvimento da atividade em questão. Além da condicionante natural, ocorreu um rápido crescimento da população urbana, que vai se concentrar sobretudo na Grande Vitória, ampliando o principal mercado consumidor de hortaliças produzidas na região serrana.

Acerca da pecuária, a bovinocultura já vinha se expandindo antes mesmo do início da modernização em decorrência da erradicação do café e, entre os anos 1960 e 1970, tanto a área quanto o rebanho mais que duplicaram no estado (tabelas 10). A atividade foi disparadamente a que mais se apropriou da área agrícola do estado, ocupando entre as décadas de 1960 e 1980 até mais 50\% dessa área. Financiada com recursos do Banco Mundial, a pecuária bovina já contava com um programa específico objetivando a ampliação da atividade e o aumento da produtividade desde os anos 1960.

Tabela 10

Espírito Santo: evolução da pecuária bovina e da avicultura (1960-1985)

\begin{tabular}{l|c|c|c|c|c}
\hline $\begin{array}{l}\text { Efetivos de animais e } \\
\text { produção }\end{array}$ & $\mathbf{1 9 6 0}$ & $\mathbf{1 9 7 0}$ & $\mathbf{1 9 7 5}$ & $\mathbf{1 9 8 0}$ & $\mathbf{1 9 8 5}$ \\
\hline Pastagem (ha) & 842656 & 1929975 & 2130563 & 1978794 & 1879617 \\
Bovinos ( $\mathrm{n}^{\circ}$.) & 653890 & 1386809 & 2104159 & 1844025 & 1759823 \\
Aves (nํ․) & - & 4222888 & 4639895 & 7362737 & 6663194 \\
Produção de ovos (mil dúzias) & - & 12336 & 16113 & 27052 & 29389 \\
\hline
\end{tabular}

Fonte: Censos Agropecuários/ES -1960, 1970, 1975, 1980 e 1985.

Elaboração: BERGAMIN, M, C. 
No âmbito da modernização, especificamente nos anos 1970, também foram criados programas nacionais específicos para a pecuária tanto leiteira quanto para corte. Não eram mais recursos externos e sim internos, via SNCR. A atividade permaneceu se expandindo e a região norte se especializou na pecuária de corte, enquanto a região sul na leiteira. Paralelo à expansão da pecuária foram instaladas agroindústrias, como frigoríficos e indústria beneficiadoras de leite, algumas delas organizadas sob o sistema de cooperativas. No entanto, a crise nos preços desestimulou a expansão da atividade segundo Souza Filho (1990), conforme pode ser verificado a partir dos anos 1980 (tabela 10).

A avicultura comercial, tanto para corte quanto para postura, também se expandiu a partir da modernização, embora não contasse com nenhum programa específico e o estado não fosse autossuficiente na produção de milho e nem produzisse soja, os dois principais insumos da ração. A avicultura é uma atividade na qual as aves são confinadas em granjas e a ração é o insumo de maior custo de produção. Dessa forma, a atividades se desenvolvia no Espírito Santo em condições competitivas desfavoráveis em relação aos estados produtores dos insumos da ração.

A atividade concentrou-se na região serrana do estado, onde as condições naturais e proximidade do maior mercado consumidor do estado favorecem o desenvolvimento da avicultura. Na região serrana as temperaturas são mais amenas e as condições do relevo, formado por serras, funcionam como barreiras fitossanitárias. Até os anos 1975 a atividade teve como maior produtor o município de Domingos Martins, mas a partir de 1980 o município de Santa Leopoldina, mais especificamente, passa a concentrar a produção para postura.

No início dos anos 1990 a produção para corte entra em crise por não conseguir concorrer com a entrada do produto de outros estados. Essa crise afetou somente a avicultura de corte, uma vez que os estados

de maior concorrência com o Espírito Santo começaram a direcionar sua produção para o mercado internacional e a receber incentivos fiscais para a construção de novas unidades de abate e modernização de parques granjeiros. Ao mesmo tempo, intensificaram a congruência de interesses na verticalização de seus empreendimentos. Isso fez com que seus produtos finais aqui chegassem com preços ainda mais baixos em função dos ganhos de escala (PEDEAG, 2004, p 6). 
Reservadas suas particularidades, a agricultura capixaba se modernizou e se constituíram alguns complexos agroindustriais, CAl's. Considerando que "O ponto fundamental que qualifica a existência do complexo é o elevado grau das relações interindustriais dos ramos ou setores que o compõem" (GRAZIANO DA SILVA, 1998, p. 31), os três exemplos de complexos mais consolidados no estado, no período em análise, foram o do cana-de-açúcar e do eucalipto e do café.

Essa integração intersetorial no estado teve como característica no setor a jusante a instalação e a expansão das agroindústrias processadoras de cana-deaçúcar, eucalipto e alimentos, mas do outro lado, no setor a montante, a instalação de indústrias para a agricultura se limitou a segmentos pouco sofisticadas, como a produção de máquinas para secagem e beneficiamento do café e fabricação de ração e fertilizante. O estado sempre dependeu da importação dessas máquinas e equipamentos, já fabricados no país, sobretudo em São Paulo

Antes da modernização a dinâmica econômica da agricultura capixaba era comandada pelo capital local. Devido ao baixo nível de incorporação técnica, não se constituiu um setor a montante especializado em fornecer insumos para a agricultura. Do outro lado, a jusante, o processamento se limitava ao beneficiamento do café (secagem e pilagem) em secadores de baixo nível tecnológico. A partir da modernização e com a constituição de alguns CAl's, como o alcooleiro de da celulose, são novas atividades que vão se desenvolver comandada pelo capital externo nacional, via SNCR, e internacional com a instalação de empresas estrangeiras.

De forma sucinta, a incorporação plena de inovações tecnológicas se restringiu a algumas atividades da agropecuária, a determinados tipos de agricultores e foi e ainda é afetada pela dependência de certas condições naturais. Naquelas atividades nas quais os avanços tecnológicos foram importantes e em áreas onde as condições naturais permitiram a mecanização, passou a se desenvolver uma agricultura moderna, fortemente capitalizada e com utilização de mão de obra assalariada, pois a divisão social do trabalho foi ampliada e o trabalhador tornou-se parcial e especializado em uma função. 


\subsubsection{Urbanização e industrialização}

A crise da estrutura produtiva, a erradicação do café e a modernização da agricultura desencadearam mudanças estruturais que redefiniram os rumos econômicos do Espírito Santo. Decorrente da crise e da erradicação, a partir nos anos 1960 a orientação do desenvolvimento estadual deslocou-se da agricultura para indústria. Foi um redirecionamento tardio, uma vez que no país ocorreu desde os anos 1930.

No entanto, as condições gerais de produção do estado não eram suficientes ou adequadas para sustentar a industrialização, como vinha ocorrendo há algumas décadas no país. A precária infraestrutura, sobretudo das estradas de rodagem e do sistema energético, não comportava as demandas do desenvolvimento pautado no setor industrial. Acrescente-se também, dadas as características produtivas do Espírito Santo, o capital acumulado localmente era insuficiente para promover a industrialização do estado, que ficava dependente da implementação de políticas externas.

Para que o estado efetivamente se industrializasse, além do capital externo que the foi direcionado por meio de políticas do governo federal, era também necessário montar a infraestrutura energética e de transportes compatível com as demandas da industrialização. Nessa perspectiva, foram construídas três usinas hidrelétricas: duas no âmbito do Plano de Metas do governo federal, Suíça e Rio Bonito, inauguradas no início da década de 1960 e Mascarenhas, inaugurada em 1974.

Para gerir o sistema energético do estado, foi criada em 1964 a Espírito Santo Centrais Elétricas - ESCELSA, empresa que tinha como função produzir, transportar e distribuir energia elétrica no Espírito Santo. Em 1968 ocorreu a federalização da ESCELSA, bem como sua integração à ELETROBRAS, ou seja, transferiu-se o problema da energia elétrica para quem tinha recursos: o governo federal.

Além da ampliação da oferta estadual de energia com a construção das usinas hidrelétricas, outro fator importante foi a conversão da frequência energética para $60 \mathrm{~Hz}$ na década de 1970, que possibilitou a interligação do sistema elétrico do Espírito Santo à região Sudeste e, consequentemente, o recebimento de outras fontes de energia (MORANDI,1997), aumentando a oferta no estado. 
Por meio de concessões do estado à ESCELSA, iniciadas no final dos anos 1960 , os serviços de fornecimento de energia elétrica foram instalados na maioria dos municípios do estado, dos quais muitos ainda não dispunham desse recurso.

Paralelo à expansão do fornecimento de energia elétrica, na infraestrutura de transportes foram realizadas grandes obras no estado entre os anos 1960 e 1970, contribuindo não só para viabilizar a industrialização, mas também o desenvolvimento de outras atividades econômicas.

No período em questão ocorreu ampla expansão do sistema rodoviário no estado, quando foram construídas três rodovias federais e diversas estradas vicinais. Nos anos 1960 foi concluída a construção tanto da BR101, que corta o Espírito Santo de norte a sul e interliga o estado ao Rio de Janeiro e à Bahia, quanto da BR262, que interliga o estado ao Centro-Oeste. Nos anos 1970 foi inaugurada outra rodovia federal, a BR259 que também interliga o estado à região Centro-Oeste.

Aproveitando os recursos federais disponíveis do IBC/GERCA decorrentes da política de erradicação do café, o governo estadual também ampliou o sistema viário, investindo na construção de diversas estradas vicinais, mas

\footnotetext{
O que se tornou decisivo para o desenvolvimento econômico capixaba foram as três rodovias federais. Em primeiro lugar, porque o Espírito Santo se integrou, de forma definitiva, às demais regiões do país. Em segundo lugar, porque possibilitaram a integração das mais importantes regiões econômicas do estado com a sua capital, que possui boa infra-estrutura portuária (ROCHA; MORANDI, 1991, p.90).
}

Essa boa infraestrutura portuária, nos anos 1960 se constituía pelo Porto de Vitória, localizado na região central da capital, que dispunha de três cais e o Porto de Tubarão, localizado na parte continental da capital. O Porto de Tubarão pertencia à Companhia Vale do Rio Doce - CVRD, e foi construído em águas de maior profundidade, ampliando consideravelmente a capacidade de movimentação de cargas portuárias. Acrescente-se também que esse modal de transporte estava integrado à ferrovia Vitória-Minas, pertencente à CVRD.

Em poucos anos foi edificada no espaço capixaba uma infraestrutura constituída por um conjunto de equipamentos de consumo coletivo que vão ser vinculadas diretamente ao processo produtivo, como rodovias, ferrovia, portos e rede de energia elétrica. Esses equipamentos são de consumo coletivo porque viabilizam a reprodução de um conjunto de capitais e também são o suporte material das 
condições gerais de produção (LENCIONI, 2007). Considerando a importância desses equipamentos para o processo de produção, eles

se desenvolvem de forma mais rápida que os indiretamente relacionados a esse processo. Essa diferença ocorre porque os equipamentos que estão em conexão direta com o processo produtivo ao permitirem a circulação da mercadoria possibilitando sua realização no mercado, agregam valor à mercadoria, pois as transformam de mercadorias em potencial à mercadorias reais. E, por isso são os prioritários (LENCIONI, 2007).

Nesse contexto, desenvolvidas as condições gerais de produção, a década de 1970 vai ser o divisor de águas da economia capixaba, uma vez que o processo de crescimento econômico orientado para a industrialização torna-se o centro dessa nova fase da economia estadual. Desde os anos 1960, quando se mudou a orientação para o desenvolvimento do estado, a atividade industrial já vinha apresentando crescimento significativo, conforme pode ser verificado na tabela 11, a participação da indústria na composição do PIB mais que dobrou entre 1960 e 1970.

Tabela 11

Espírito Santo: Composição Setorial do PIB - 1960-1990

\begin{tabular}{l|c|c|c|c}
\hline Setores & $\mathbf{1 9 6 0}$ & $\mathbf{1 9 7 0}$ & $\mathbf{1 9 8 0}$ & $\mathbf{1 9 9 0}$ \\
\hline Agropecuária e pesca & 41,8 & 20,8 & 14,7 & 6,0 \\
Indústria & 5,3 & 13,2 & 36,2 & 36,4 \\
Comércio e serviços & 52,9 & 66,1 & 49,1 & 57,6
\end{tabular}

Fonte: Elaboração de Sávio Caçador a partir de dados do Ipeadata.

No entanto, nesse período ainda era "o capital local, em geral de pequeno porte, que cresceu apoiado em financiamento e incentivos fiscais proporcionado pelo Estado" (ROCHA; MORANDI, p. 94, 1991) que comandava o processo de industrialização, predominando, então, indústrias de pequeno e médio porte, vinculadas sobretudo ao setor alimentício. Os incentivos fiscais foram criados pelo Decreto Lei 880 de 1969, do governo federal, e permitia que parte do imposto de renda gerado no Espírito Santo fosse aplicada no próprio estado.

Mas a partir dos anos 1970 a dinâmica econômica passa a ser outra. No âmbito do II Plano Nacional de Desenvolvimento - II PND, cujas diretrizes buscavam atenuar as disparidades regionais, o que favorecia o Espírito Santo, e aproveitando as vantagens locacionais, inicia-se a implementação dos grandes projetos industriais, compreendidos pela usina de pelotização da CVRD, Companhia 
Siderúrgica de Tubarão - CST, Samarco Mineração e Aracruz Celulose, sendo as duas primeiras as maiores, localizadas nos municípios de Vitória e de Serra e as outras duas nos municípios litorâneos de Anchieta e de Aracruz, respectivamente.

Como consequência entre 1970 e 1980 a atividade industrial suplantou a agrícola e a participação do PIB industrial quase triplicou (tabela 11). A implantação dos grandes projetos industriais, estabeleceu um novo padrão de crescimento econômico e permitiu que o estado se integrasse ao mercado nacional, produzindo bens de consumo intermediário para exportação.

Em apenas uma década a dinâmica econômica foi profundamente alterada e ao mesmo tempo em que o estado se industrializava, no campo, após a crise da estrutura produtiva e da erradicação, estava ocorrendo a modernização da agricultura. O centro da acumulação deslocou-se da agricultura para a indústria e do campo para a cidade. Se no campo as mudanças estruturais expulsavam a população, nos municípios da região da Grande Vitória, o processo de industrialização atraía. Como consequência, ocorreu intenso movimento migratório em direção à Grande Vitória, cuja população cresceu de forma acelerada. Em meio século o incremento populacional da Grande Vitória foi de aproximadamente dez vezes (tabela 12).

Tabela 12

Espírito Santo e Grande Vitória: evolução demográfica

\begin{tabular}{l|c|c|c|c|c}
\hline $\begin{array}{l}\text { Municípios da Grande } \\
\text { Vitória }\end{array}$ & $\mathbf{1 9 5 0}$ & $\mathbf{1 9 6 0}$ & $\mathbf{1 9 7 0}$ & $\mathbf{1 9 8 0}$ & $\mathbf{1 9 9 1}$ \\
\hline Cariacica & 21741 & 39608 & 101422 & 189099 & 274532 \\
Serra & 9245 & 9192 & 17286 & 82568 & 222158 \\
Viana & 5896 & 6565 & 10529 & 23440 & 43866 \\
Vila Velha & 23127 & 55587 & 123742 & 203401 & 265586 \\
Vitória & 50922 & 83351 & 133019 & 207736 & 258777 \\
Grande Vitória & 110911 & 198265 & 385998 & 706263 & 1082772 \\
Espírito Santo & 957238 & 1418384 & 1599333 & 2023340 & 2600618 \\
\% da Grande Vitória na & 11,6 & 14,0 & 24,1 & 34,9 & 41,6 \\
população estadual & & & & & \\
\hline
\end{tabular}

Fonte: Censos Demográficos/ES -1950, 1960, 1970, 1980 e 1991.

Elaboração: BERGAMIN, M, C.

Em 1950 o município mais populoso do estado era a capital, que contava com pouco mais de 50 mil habitantes (tabela 12). Nessa década $77,4 \%$ da população do estado ainda residiam no campo (tabela 7), sendo que grande parte desses habitantes ainda produzia de forma direta uma boa parte dos meios de vida, 
principalmente a alimentação; acrescente-se também que poucos trabalhadores eram assalariados e a dependência das cidades para a sobrevivência era pequena. Isso porque a estrutura produtiva assentada na cafeicultura e no trabalho familiar interferiu na formação do mercado consumidor e de trabalho e consequentemente na urbanização.

À medida que as transformações estruturais do Espírito Santo iam ocorrendo, os fluxos migratórios direcionados para a Grande Vitória se intensificavam. Entre 1960 a 1970, a Grande Vitória recebeu 131.430 imigrantes (CASTEGLIONI, 1989). Considerando que em 1970 a região tinha 385.998 habitantes, os imigrantes representavam aproximadamente $1 / 3$ dessa população. No entanto, ainda eram fluxos migratórios internos, uma vez que "na década de 60, a migração externa ainda não alcançava o percentual de 10\% sobre o total de migrantes" (SIQUEIRA, 2001, p. 142). Entre 1970 e 1980 entraram 282.677 migrantes na Grande Vitória, dos quais 82.138 eram provenientes de outros estados (CASTEGLIONI, 1989). Decorrente dos "Grandes Projetos Industriais", a Grande Vitória exerceu atratividade além dos limites estaduais.

Dessa forma, a Grande Vitória passou a concentrar cada vez mais, maior percentual da população do estado. Entre 1950 e 1991 a participação da população da Grande Vitória em relação ao estado saltou de 11,6\% para 41,6 (tabela 12). Ressalta-se que a população da Grande Vitória, em 1950 já era predominantemente urbana (IBGE, 1950).

É importante salientar que a industrialização da Grande Vitória, via grandes projetos, promoveu o crescimento econômico do estado, mas desencadeou graves problemas sociais na região, como a expansão das favelas, o desemprego, o trabalho informal e de baixa remuneração. As mudanças estruturais da segunda metade do século $X X$, que culminaram com a industrialização do estado, foram também responsáveis pela ampliação considerável da pobreza, pois

Dos 706.263 habitantes concentrados na Grande Vitória em 1980, 338.507 $(47,9 \%)$ pessoas eram consideradas carentes. Desse total, 281.391 estavam distribuídas em 83 áreas de favelas, quer dizer, habitações desumanas, sem as mínimas condições de higiene, com deficiência de luz, água e saneamento básico. Os demais se distribuíam em bairros populares carentes (SIQUEIRA, 2001, p.150). 
Mesmo que o crescimento populacional tenha ocorrido de forma desordenada, desencadeando os tradicionais problemas da urbanização brasileira, constituiu-se na Grande Vitória o maior mercado consumidor do estado. Apesar da magnitude da pobreza, a maioria da população da Grande Vitória não era mais produtora direta dos meios de vida, mas consumidora de mercadorias. Além disso, cada vez mais a população do estado passou a residir em cidades, em 1980 63,9\% da população do estado era urbana (tabela 6), e a trabalhar de forma assalariada, ou seja, para sobreviverem passaram a depender tanto da cidade quanto do mercado.

A urbanização, a dependência da cidade e do mercado para a sobrevivência e a formação do maior mercado consumidor na Grande Vitória, são elementos contribuir diretamente para a introdução e expansão dos cultivos de hortaliças e da avicultura de postura em Santa Maria de Jetibá, atividades que passam a se desenvolver com fins comerciais e não mais voltada para a produção direta dos meios de vida.

\subsubsection{Manifestações das transformações estruturais do Espírito Santo em Santa Maria de Jetibá}

Quando ocorreram as transformações estruturais do Espírito Santo, o território de Santa Maria de Jetibá pertencia à Santa Leopoldina, pois foi elevado à categoria de município somente em 1988. Dessa forma, para compreendermos como se manifestaram as transformações estruturais do Espírito Santo em Santa Maria de Jetibá, pela quase indisponibilidade de informações específicas para esse território, usaremos a maioria dos dados referentes à Santa Leopoldina. Considerando as limitações dos dados disponíveis, é importante salientar que tais informações representam uma aproximação da realidade de Santa Maria de Jetibá.

As únicas exceções são alguns poucos dados do Censo Demográfico, os quais estão organizados por distritos e do Censo Agropecuário de 1980, organizados por setor censitário em um trabalho elaborado pelo Instituto Jones dos Santos Neves. Tanto os dados distritais quanto os por setores censitários, embora sejam poucos, possibilitaram obter informações específicas do território de Santa Maria de Jetibá, no período anterior à emancipação política. 
No Censo Agropecuário de 1995/96 Santa Maria de Jetibá aparece pela primeira vez como município e esses dados serviram como parâmetro para identificar a participação de Santa Maria de Jetibá na produção agropecuária de Santa Leopoldina nos anos anteriores. Constatou-se que $2 / 3$ do valor da produção agrícola $(66,5 \%)$ e $82 \%$ do efetivo de aves dois municípios estavam concentrados em Santa Maria de Jetibá (Censo Agropecuário, 1995/96). Detalhando um pouco mais o valor da produção agrícola, Santa Maria de Jetibá concentrava 87,4\% das hortaliças, $71 \%$ das culturas temporárias e $47,7 \%$ das culturas permanentes (Censo Agropecuário, 1995/96). A partir desses dados, depreende-se que grande parte da produção agropecuária de Santa Leopoldina era proveniente do território de Santa Maria de Jetibá.

Inserido no município de Santa Leopoldina, o território de Santa Maria de Jetibá se particulariza pelo aspecto natural e humano. Esse território apresenta altitudes bem elevadas e declividade acentuada, elementos naturais que vão influenciar a produção agrícola; no aspecto humano, os descendentes de pomeranos são predominantes e isso não é um simples detalhe, mas tem manifestações importantes na relação que estabeleceram com o trabalho. No entanto, outros aspectos são semelhantes, pois tanto Santa Leopoldina quanto Santa Maria de Jetibá se originaram de uma colônia de imigrantes europeus, onde até o presente predominam pequenas propriedades rurais e o trabalho familiar.

Primeiramente, o território de Santa Maria de Jetibá era essencialmente rural, pois até 1970 menos de $1 \%$ de sua população era urbana. Ao se considerar a população de Santa Leopoldina, mas excluindo o território de Santa Maria de Jetibá, o percentual de população urbana do município sempre foi superior a $11 \%$ no período abordado pela tabela 13. Acrescente-se também que nessa época o estado caminhava para a urbanização, pois $45,1 \%$ da sua população era urbana em 1970 (tabela 6).

Um território com população rural quase absoluta até 1970 e localizado a $80 \mathrm{~km}$ da capital do estado, tem estreita relação com o predomínio dos descendentes de pomeranos. Isolados e fechados entre as serras que formam o relevo de Santa Maria de Jetibá, dominando pouco o português, mantendo os casamentos intragrupal, esses descendentes permaneceram na agricultura produzindo de forma 
direta os meios de vida, sem que a sobrevivência da família dependesse das cidades. Até 1970 a população urbana era inferior a 52 habitantes.

Tabela 13

Evolução da população do território de Santa Maria de Jetibá* (1940/1980)

\begin{tabular}{l|c|c|c|c|c}
\hline População & $\mathbf{1 9 4 0}$ & $\mathbf{1 9 5 0}$ & $\mathbf{1 9 6 0}$ & $\mathbf{1 9 7 0}$ & $\mathbf{1 9 8 0}$ \\
\hline População total & 6395 & 7785 & 9723 & 10187 & 15962 \\
População rural & 6371 & 7733 & 9675 & 10143 & 14585 \\
População urbana & 24 & 52 & 48 & 44 & 1377 \\
$\begin{array}{l}\text { População rural (\%) } \\
\text { \% da população de Santa Maria de Jetibá em } \\
\text { relação a Santa Leopoldina }\end{array}$ & 99,62 & 99,33 & 99,50 & 99,56 & 91,37 \\
\hline
\end{tabular}

Fonte: Censos Demográficos/ES -1940, 1950, 1960, 1970 e 1980.

Elaboração: BERGAMIN, M, C.

Foi considerada a população dos distritos de Jetibá e Garrafão, os quais foram desmembrados de Santa Leopoldina para formar o município de Santa Maria de Jetibá.

Nesse contexto, na estrutura produtiva de Santa Maria de Jetibá, da mesma forma que no estado, predominava o trabalho familiar, a pequena propriedade e 0 cultivo do café sem recursos técnicos. Considerando o seu passado como parte de uma colônia imperial, a pequena propriedade e o trabalho familiar eram ainda mais expressivos que a média estadual. Em 1960, no município de Santa Leopoldina $94,15 \%$ das relações de trabalho eram realizadas pelo responsável e os membros não remunerados da família, enquanto no estado esse percentual era de $55,93 \%{ }^{7}$ (IBGE/Censo Agropecuário, 1960).

No entanto, em relação à cafeicultura a posição do município se inverte. Se a produtividade da cafeicultura estadual era inferior à média das principais regiões produtoras do país, em Santa Leopoldina era inferior à média estadual. Na tabela 14 verifica-se que, no período que antecede a modernização da agricultura, a produtividade do café em Santa Leopoldina sempre foi bem inferior à média do estado. Mas o que nos interessa nesses dados, é que a produtividade da cafeicultura de Santa Maria de Jetibá, devido a altitude mais elevada (Figura 5) e imprópria à atividade, certamente era inferior à média de Santa Leopoldina.

\footnotetext{
7 Nesse percentual não estava incluída a parceria, uma relação de trabalho familiar e que representava $24,44 \%$ da mão de obra empregada na agricultura estadual.
} 
Tabela 14

Espírito Santo e Santa Leopoldina: evolução da produtividade da cafeicultura 1960/1985 (T/ha)

\begin{tabular}{l|cc|c|c|c|c}
\hline \multicolumn{1}{c|}{ Anos } & $\mathbf{1 9 5 0}$ & $\mathbf{1 9 6 0}$ & $\mathbf{1 9 7 0}$ & $\mathbf{1 9 7 5}$ & $\mathbf{1 9 8 0}$ & $\mathbf{1 9 8 5}$ \\
\hline Santa Leopoldina & 0,61 & 0,48 & 0,71 & 0,62 & 0,94 & 1,12 \\
Espírito Santo & 0,94 & 0,74 & 0,92 & 0,58 & 1,03 & 1,08 \\
\hline
\end{tabular}

Fonte: IBGE/Censos Agropecuários/ES -1960, 1970, 1975, 1980 e 1985.

Elaboração: BERGAMIN, M, C.

Diante dos baixos níveis de produtividade do café em Santa Leopoldina, ocorreu uma ampla adesão dos agricultores à política de erradicação, uma vez que entre 1960 e 1970 a área ocupada pela atividade foi reduzida a 1⁄4, ou seja, de 6010 ha para 1493 ha (tabela 15). A intensidade da erradicação no município foi bem maior que no estado, pois, retomando Buffon (1992), se a cafeicultura fosse produtiva não haveria tantos adeptos à política. Receber a indenização por cada pé de café erradicado era, então, muito mais vantajoso que continuar produzindo.

Tabela 15

Santa Leopoldina: evolução de algumas atividades agropecuárias (1960-1985)

\begin{tabular}{|c|c|c|c|c|c|c|c|c|c|c|}
\hline \multirow[b]{2}{*}{ Cultura } & \multicolumn{2}{|c|}{1960} & \multicolumn{2}{|c|}{1970} & \multicolumn{2}{|c|}{1975} & \multicolumn{2}{|c|}{1980} & \multicolumn{2}{|c|}{1985} \\
\hline & $\begin{array}{l}\text { Área } \\
\text { (ha) }\end{array}$ & $\begin{array}{c}\text { Produção/ } \\
\text { Rebanho }\end{array}$ & $\begin{array}{l}\text { Área } \\
\text { (ha) }\end{array}$ & \begin{tabular}{|c|} 
Produção/ \\
Rebanho \\
\end{tabular} & $\begin{array}{r}\text { Área } \\
\text { (ha) }\end{array}$ & $\begin{array}{c}\text { Produção/ } \\
\text { Rebanho }\end{array}$ & $\begin{array}{c}\text { Área } \\
\text { (ha) }\end{array}$ & $\begin{array}{c}\text { Produção/ } \\
\text { Rebanho }\end{array}$ & $\begin{array}{l}\text { Área } \\
\text { (ha) }\end{array}$ & \begin{tabular}{|c|} 
Produção/ \\
Rebanho
\end{tabular} \\
\hline die & 6010 & 2855 & 1493 & 1063 & 1656 & 1025 & 5650 & 5305 & 9522 & 10691 \\
\hline the & 775 & 537 & 428 & 893 & 1166 & 1087 & 1303 & 15 & 1923 & 2020 \\
\hline & 2324 & 8 & 1 & & 3012 & & 3169 & & 3 & 2424 \\
\hline vidi & 1892 & 9011 & 1743 & 21893 & 2646 & 16943 & 1333 & 7832 & 1844 & 6873 \\
\hline lilhot & 5045 & 4037 & 3629 & 3024 & 4326 & 3322 & 4228 & 3626 & 4820 & 4995 \\
\hline & 16781 & 15053 & 26746 & 15503 & 25732 & 17785 & 23600 & 15093 & 21970 & 15475 \\
\hline & - & 135367 & - & 244662 & - & 430400 & $\begin{array}{l}- \\
-\end{array}$ & 991016 & - & 1007544 \\
\hline Ovos $^{4}$ & - & - & - & 1409 & _. & 2518 & - & 9214 & - & 10933 \\
\hline
\end{tabular}

Fonte: IBGE/Censos Agropecuários/ES -1960, 1970, 1975, 1980 e 1985.

Elaboração: BERGAMIN, M, C.

1 Toneladas, ${ }^{2} 1000$ cachos, ${ }^{3}$ bovina e ${ }^{4}$ mil dúzias.

Apesar da intensidade, o pós-erradicação apresenta particularidades. Diferentemente do estado onde houve um importante avanço da pecuária em detrimento da diversificação produtiva no pós-erradicação, em Santa Leopoldina não só ocorreu uma certa diversificação produtiva, conforme um dos objetivos da política, bem como, a pecuária não se expandiu. Entre 1960 e 1970, houve sim um avanço maior da área ocupada pela pecuária, conforme tabela 15, mas em proporções inferiores ao estado e após esse período a área ocupada pela atividade foi sendo 
reduzida. No entanto, a ampliação da área não foi acompanhada pela expansão do efetivo de bovinos, que permaneceu praticamente o mesmo. Dessa forma,

\begin{abstract}
Ocorre que durante essa década de 60 , houve uma drástica diminuição das lavouras, em torno de 7 mil hectares, dos quais 5 mil de lavouras permanentes. Em função disso, liberou-se muita terra no município, fazendo até aumentar a área considerada como pastagens, sem, no entanto, elevar o efetivo bovino (IJSN, 1983, p. 15 e 16)
\end{abstract}

Como predominavam pequenas propriedades e haviam muitas áreas com declividade acentuada, não se tratava de um município cujas condições naturais fossem adequadas à pecuária bovina em sistema extensivo. Muitas áreas erradicadas foram abandonadas e ocupadas por pastagens naturais, sem que efetivamente houvesse investimento no efetivo de bovinos.

Mas por outro lado, a avicultura de postura, uma atividade sem nenhuma tradição no estado, emerge nos anos 1960 no território de Santa Maria de Jetibá e se expande nas décadas subsequentes. A atividade passa a ser desenvolvida com fins comerciais, diferindo-se da produção doméstica existente. Conforme pode ser verificado na tabela 15, tanto a produção de ovos, quanto o efetivo de galinhas, crescem vertiginosamente. Em 1980 Santa Leopoldina já respondia por 34\% da produção estadual de ovos e destacava-se como o maior produtor do Espírito Santo (IBGE/Censo Agropecuário, 1980). No entanto, grande parte dessa produção estava concentrada no território de Santa Maria de Jetibá, que detinha $86,04 \%$ do efetivo de aves do município (IJSN, 1983).

Concernente à produção agrícola, verifica-se também que entre 1960 e 1970, logo após a erradicação dos cafezais, a área ocupada pelas culturas tradicionais e voltadas para a alimentação, como feijão, mandioca e milho, foi reduzida. Embora a partir de 1970 inicie-se uma tendência de ampliação desses cultivos, tanto em área quanto em produção, não foram essas as culturas que substituíram o café e tampouco as responsáveis pela diversificação produtiva.

Quando se afirma que ocorreu diversificação produtiva é porque outras culturas, no caso as hortaliças, emergem e se expandem em Santa Leopoldina. Em 1960 o município já se destacava como produtor de hortaliças, que representavam $17,8 \%$ do valor total da sua produção agrícola (ROCHE, 1968). Além disso, das 7 (sete) variedades levantadas pelo Censo Agropecuário, o município destacava-se 
como maior produtor estadual de 4 (quatro) (quadro 2). Em 1970 essa produção se expande, uma vez que das 18 (dezoito) hortaliças pesquisadas, o município era um dos maiores produtores de 14 (quatorze) variedades. Embora em 1980 o município se destacasse como grande produtor de somente 6 (seis) variedades das 12 (doze) pesquisadas, o valor da produção das hortaliças correspondia a $29,92 \%$ do total estadual (Censo Agropecuário, 1980).

\begin{tabular}{|c|c|c|c|c|}
\hline \multicolumn{5}{|c|}{$\begin{array}{c}\text { Quadro } 2 \\
\text { Santa Leopoldina: posição entre os municípios do Espírito Santo na produção de } \\
\text { hortaliças }^{8}\end{array}$} \\
\hline $\begin{array}{l}\text { Posição do } \\
\text { município }\end{array}$ & $1^{\circ}$ produtor & $2^{\circ}$ produtor & 3ㅇ produtor & $\begin{array}{l}\text { № de } \\
\text { hortaliças } \\
\text { levantadas }\end{array}$ \\
\hline 1960 & $\begin{array}{l}\text { batata inglesa, repolho } \\
\text { e tomate }\end{array}$ & - & - & 07 \\
\hline 1970 & $\begin{array}{l}\text { alho, cenoura, chuchu, } \\
\text { couve flor, jiló, pepino, } \\
\text { pimentão, repolho, } \\
\text { tomate e vagem }\end{array}$ & alface, cebola, inhame & couve & 18 \\
\hline 1975 & $\begin{array}{l}\text { beterraba, cenoura, } \\
\text { chuchu, couve-flor, jiló, } \\
\text { pepino, pimentão } \\
\text { repolho e vagem }\end{array}$ & cebola, & batata inglesa & 19 \\
\hline 1980 & $\begin{array}{l}\text { cebola, chuchu, pepino, } \\
\text { pimentão }\end{array}$ & cenoura, & batata inglesa & 12 \\
\hline 1985 & $\begin{array}{l}\text { abobrinha, alface, alho, } \\
\text { beterraba, chuchu, jiló, } \\
\text { pepino, pimentão, } \\
\text { repolho e vagem }\end{array}$ & cebola, cenoura, & inhame & 23 \\
\hline
\end{tabular}

Depreende-se então que as hortaliças substituíram o café, ocorrendo a diversificação produtiva objetivada pela política de erradicação, pois essas culturas eram "praticadas sobretudo no Distrito de Santa Maria de Jetibá, do município de Santa Leopoldina, e em bem mais insignificante medida em alguns pontos dos municípios de Domingos Martins e Itaguaçu" (ROCHE, 1968, p. 93). Desde que a horticultura comercial emergiu e se expandiu no estado, essa atividade sempre esteve concentrada no território de Santa Maria de Jetibá.

\footnotetext{
${ }^{8}$ De acordo com a Classificação Nacional das Atividades Econômicas - CNAE, na qual se fundamenta - Censo Agropecuário, o cultivo de hortaliças compreende: hortaliças folhosas e de talo, hortaliças de frutos ou legumes, hortaliças tuberosas, hortaliças para grãos e vagens, hortaliças condimentares e medicinais, cogumelos comestíveis e morango.
} 
No entanto, mesmo considerando que essa produção de hortaliças estivesse concentrada em Santa Maria de Jetibá e também sua elevada capacidade de reter mão de obra, a expansão da atividade não foi suficiente para absorver os impactos da erradicação, cuja adesão foi tão ampla conforme abordado. O êxodo rural desencadeado pela erradicação não chegou a diminuir a população rural em números absolutos, mas reduziu seu ritmo de crescimento. Entre 1960 e 1970, o percentual de crescimento da população rural de Santa Maria de Jetibá foi a metade do estado, indicando que a erradicação expulsou muitos agricultores. Nesse período verifica-se também acentuada elevação do índice de Gini, de 0,350 para 0,401 (BERGAMIM, 2004), embora ainda revele baixo nível de concentração fundiária.

Apesar da substituição em questão, as áreas ocupadas pelas hortaliças não foram aquelas liberadas pela erradicação. Em princípio essas áreas tornaram-se pastagens naturais e em menor intensidade foram ocupadas com alguns cultivos tradicionais. Os cultivos de hortaliças ocuparam outras áreas, as várzeas, pois

\footnotetext{
São praticados essencialmente em terrenos baixios, antigos alagadiços, nos vales em que as vertentes foram desmatadas para a plantação de café, transformadas atualmente em pastagens. Tais "brejos", abandonados no começo pelos colonos, reduzindo-lhes o valor das propriedades, constituem hoje o essencial de seus patrimônios. Os benefícios que lhes proporciona a nova exploração, valorizou-as consideravelmente (ROCHE, 1968, p. 93 e 94).
}

A altitude elevada e as várzeas que outrora eram desfavoráveis ao cultivo do café, na medida em que se introduz uma nova atividade econômica e adequada a tais condições naturais, transformam-se elementos que não apenas oferecem novas e melhores oportunidades produtivas, mas também valorizam a propriedade da terra.

Principalmente nessas várzeas foi desenvolvida a horticultura comercial, cujo início da expansão antecedeu a modernização da agricultura no estado. A atividade tem ciclo curto e o manejo é intensivo, tanto em trabalho quanto na utilização de insumos, sobretudo quando comparado com o padrão tecnológico da cafeicultura anteriormente modernização. Decorrente da horticultura, localizada sobretudo no território de Santa Maria de Jetibá, Santa Leopoldina passou a incorporar inovações técnicas antes mesmo da modernização da agricultura ser iniciada no estado, embora ainda não fossem as inovações industriais moderna. 
Em termos relativos, em 1960 era o município que mais usava adubos, com $21,96 \%$ das propriedades incorporando tal inovação (tabela 15). Nos anos subsequentes, o município seguiu destacando-se sempre como um dos maiores incorporadores de tal insumo. Conforme pode ser observado na tabela 15, em 1970, antes mesmo da modernização ser iniciada, praticamente metade das propriedades já usava adubos. Nesse mesmo período a média do país era de $15,43 \%$ e a do estado $11,22 \%$ (tabela 8), ou seja, bem inferiores ao município.

Não era um insumo industrial, mas sim adubo de origem predominantemente orgânica, proveniente da avicultura comercial desenvolvida no município vizinho, Domingos Martins, e posteriormente no próprio município. Até 1970 praticamente só se usava adubo orgânico no município, um insumo extremamente adequado às exigências nutricionais das hortaliças que começa a ser disponibilizado localmente.

A oferta local de estercos provenientes das granjas, foi um fator de estrema importância para viabilizar a horticultura em Santa Maria de Jetibá. A altitude e as várzeas, outrora inadequadas produtivamente, associadas ao uso de adubo orgânico que vai conferir aos solos a fertilidade demandada pela horticultura, oferecem as condições necessárias para expandir a produção.

À medida que a modernização toma ímpeto no Espírito Santo, o uso dos adubos químicos se expande em Santa Leopoldina, mas excetuando os anos 1980, sempre em proporção menor que os orgânicos (tabela 16). Com os defensivos químicos, desde que se começou a levantar essa informação, o percentual de uso sempre foi elevado, ultrapassando $70 \%$ das propriedades. No entanto, os dados do Censo Agropecuário indicam apenas o número de propriedades que fazem uso desse insumo, mas não frequência. No caso das hortaliças essa frequência chega a ser semanal.

Tabela 16

Santa Leopoldina: indicadores de modernização (1960/1985)

\begin{tabular}{l|c|c|c|c|c}
\hline Indicadores & $\mathbf{1 9 6 0}$ & $\mathbf{1 9 7 0}$ & $\mathbf{1 9 7 5}$ & $\mathbf{1 9 8 0}$ & $\mathbf{1 9 8 5}$ \\
\hline Área média explorada por trator (ha) & 10887 & 3301 & 1728 & 239 & 129 \\
Área irrigada (ha) & 68 & 525 & 1311 & 2266 & 3805 \\
Propriedades com uso de adubos (\%) & 21,96 & 49,46 & 74,79 & 87,17 & 92,41 \\
Propriedades com uso de adubos orgânicos (\%) & 20,64 & 40,17 & 68,81 & 67,75 & 92,24 \\
Propriedades com uso de adubos químicos (\%) & 0 & 9,04 & 44,77 & 79,79 & 86,60 \\
Propriedades com uso de defensivos (\%) & - & - & 73,55 & 78,73 & 73,42 \\
\hline
\end{tabular}

Fonte: IBGE/Censos Agropecuários/ES -1960, 1970, 1975, 1980 e 1985.

Elaboração: BERGAMIN, M, C.

- Dado inexistente 
Bastante relacionadas a expansão da horticultura, outras inovações técnicas foram incorporadas no município e em intensidade maior que no estado. Por serem culturas de ciclo curto e que demandam frequentemente a preparação dos solos, o número de tratores foi bastante ampliado. Até 1960, em Santa Leopoldina a área média explorada por trator era maior que no estado. Enquanto no município havia um trator para cada 10887ha (tabela 16), no estado havia um para cada 7239 ha (tabela 7), mas a partir de 1970, a situação se inverte. A área explorada por trator vai sendo reduzida e em 1985, era um trator para cada 129 ha, o que correspondia a uma área três vezes inferior à do estado.

Associada à horticultura, devido a necessidade de recebimento regular de água da atividade, a irrigação foi outra inovação técnica também incorporada. Se em 1960 eram somente 68 ha irrigados, pois ainda não havia energia elétrica. Ou se irrigava por gravidade, onde fosse possível, ou usava-se diesel. Em 1975, quando a modernização deslancha no estado, já eram 1311 ha com sistemas de irrigação, mas dez anos depois, essa área já havia sido quase triplicada, conforme tabela 16.

Face a todas as transformações desencadeadas no território de Santa Maria de Jetibá a partir da crise da estrutura produtiva, da erradicação da cafeicultura e da modernização da agricultura, constata-se que num primeiro momento houve a saída da população do campo. Isso ocorreu no pós-erradicação, quando entre 1960 e 1970 a população rural foi ampliada em apenas $4,84 \%$, mas na década seguinte, entre 1970 e 1980, essa ampliação foi de 43,79\% (tabela 13). Esse dado indica que na década em que a modernização ocorreu de forma mais intensa, houve um grande crescimento da população rural.

A explicação para o crescimento da população rural de Santa Maria de Jetibá tem relação com a industrialização e urbanização do Espírito Santo. Devido a concentração dos projetos industriais na Grande Vitória, entre 1970 e 1980, a população da região saltou de 385.998 para 706.263 habitantes (tabela 12). Isso significa que houve uma importante expansão do mercado consumidor essencialmente urbano, aumentando a demanda pela produção de hortaliças e de ovos de Santa Maria de Jetibá.

Esse não é um caso isolado, pois no contexto da modernização da agricultura brasileira, os impactos da urbanização rápida do país na agricultura, manifestaramse "sobre o setor agrícola em profundidade, produzindo movimentos de população e 
elevação da demanda por produtos agropecuários que transformam inteiramente os espaços previamente definidos como rurais e urbanos" (DELGADO, 1984, p. 23).

Nesse contexto, no auge da modernização em Santa Maria de Jetibá, criouse mais possibilidades de permanência da população no campo, pois expandia-se uma atividade agrícola intensiva em mão de obra e que ao incorporar progresso técnico, demandava áreas ainda menores para ser viável economicamente.

Verifica-se também que a população do território de Santa Maria de Jetibá foi crescendo, ampliando sua participação em relação a Santa Leopoldina, tornando-se ligeiramente maior nos anos 1960, com uma queda na década seguinte, até superála definitivamente a partir de 1980 (tabela 13). Depreende-se então, que as opções produtivas da agropecuária de Santa Maria de Jetibá tornaram-se atrativas e fixadoras da população no campo.

Tal realidade, contrária à lógica dominante da modernização de sempre causar de êxodo rural, deve-se as opções produtivas que ocorreram no território de Santa Maria de Jetibá. As duas principais atividades que vão se expandir, a horticultura e a avicultura de postura, são destinadas ao mercado interno e produtoras de alimentos, diferenciando-se das escolhas produtivas predominantes no Espírito Santo. A primeira é intensiva em trabalho e requer pequenas áreas para assegurar a sobrevivência de uma família. Na segunda, a terra não é um meio de produção, mas somente um substrato para sua instalação.

Isso não significa que a modernização da agricultura em Santa Maria de Jetibá não tenha sido permeada por uma série de conflitos entre os diversos sujeitos sociais que integram as cadeias produtivas das diferentes atividades da agropecuária. Em termos produtivos a modernização promoveu importantes avanços, mas ao mesmo tempo, subordinou o agricultor à indústria de insumos, máquinas e equipamentos agrícolas. Dessa forma, o agricultor tornou-se duplamente subordinado ao capital: primeiro ao comerciante no momento da venda da produção, subordinação ocorrida desde o início da colônia e, depois, à indústria voltada para agricultura, antes de começar a produzir. 


\section{AVICULTURA DE POSTURA EM SANTA MARIA DE JETIBÁ: UMA PRODUÇÃO DETERMINADA PELAS GRANJAS DE PORTE GRANDE E MODERNAS TECNOLOGICAMENTE}

\subsection{O surgimento da avicultura de postura e a fundação da cooperativa de avicultores na década de 1960}

A produção doméstica de galinhas sempre fez parte do cotidiano dos agricultores de Santa Maria de Jetibá. Era a tradicional criação de galinhas caipiras, sem melhoramento genético, plenamente dependente das condições naturais e, dessa forma, o processo de produção biológico era descontínuo, bastante lento e com produtividade muito baixa quando comparado aos padrões atuais. Para exemplificar, as aves começavam a fase da postura somente a partir do oitavo mês de vida e produziam poucos ovos por ano.

Conforme pode ser verificado na tabela 17, o ciclo produtivo da galinha caipira em relação à postura é constituído por várias fases que se repetem inúmeras vezes ao longo da vida produtiva da ave. Dessa forma, seguindo o ciclo natural da espécie, o processo produtivo dos ovos ocorre de forma sequencial, descontínua e com vários tempos de espera, quando não há nenhuma produção.

Tabela 17

Ciclo reprodutivo da galinha caipira de acordo com as fases reprodutivas

\begin{tabular}{l|c|c}
\multirow{3}{*}{ Fases } & \multicolumn{3}{c}{ Forma de incubação } \\
\cline { 2 - 3 } & Natural & Artificial \\
\hline Pré-postura (dias) & 8 & 8 \\
Postura (dias) & 15 & 15 \\
Choco (dias) & 21 & 0 \\
Pós-choco (dias) & 3 & 3 \\
Total (dias) & 47 & 26 \\
№ de ciclos anuais & 7 & 13 \\
\hline
\end{tabular}

Fonte: Embrapa, 2007.

Considerando uma ave em idade produtiva, esse ciclo se reproduz da seguinte forma: pré-postura, ocorre após o pós-choco; a postura, quando a galinha põe de 10 a 15 ovos seguidamente; o choco, quando a galinha interrompe a postura devido a um processo natural desenvolvido pelas aves para poderem se dedicar à 
incubação dos ovos; pós-choco, quando a galinha conduz os pintinhos recémnascidos (EMBRAPA, 2007).

Se a incubação dos ovos ocorrer de forma natural esse ciclo tem duração de 47 dias e ao longo de um ano pode se repetir até sete vezes (tabela 17). Dessa forma, em condições normais, a produção anual de uma galinha seria de 70 a 105 ovos. No entanto, o choco pode ser suspenso com o uso de algumas técnicas, como mergulhando a galinha na água ou colocando-a em ambientes molhados. Suspenso o choco, o ciclo produtivo da galinha pode ser reduzido e ampliada a produção de ovos por ave.

Apesar da lentidão do processo produtivo e da baixa produtividade, os custos de produção da atividade eram irrisórios. Tratava-se uma produção destinada prioritariamente ao consumo da família e sem fins comerciais, uma vez que o mercado local tanto para ovos quanto para carne praticamente inexistia. Na década de 1960 menos de 1/3 da população do Espírito Santo era urbana (Tabela 6).

Não havia separação entre a produção para corte e para postura pois não se usava espécies melhoradas geneticamente que diferenciasse o tipo de ave para cada atividade. A mesma ave era criada com dupla finalidade e as duas atividades ocorriam juntamente. Normalmente as atividades relacionadas à criação das aves eram de responsabilidade das mulheres, uma vez que estavam assentadas em bases familiares de produção.

No entanto, a produção de ovos em Santa Maria de Jetibá começou a tomar novos rumos a partir de em 1962, quando foi realizada a primeira experiência com avicultura de postura comercial. O pioneiro na atividade foi Erasmo Berger, que após realizar curso técnico na Escola Wenceslao Bello, localizada no Rio de Janeiro e pertencente à Sociedade Nacional de Agricultura, aprendeu técnicas da avicultura de postura. Com o conhecimento adquirido Erasmo Berger introduziu a atividade em Santa Maria de Jetibá em 1962.

A primeira granja de postura foi construída em um local que atualmente faz parte da área urbana de Santa Maria de Jetibá, mais especificamente no centro da cidade, onde está localizada a agência do Banco do Estado do Espírito Santo BANESTES, na sede do município. Nessa época a população urbana do território que corresponde à Santa Maria de Jetibá era inferior a 50 habitantes (tabela 13). 
A atividade foi iniciada com um plantel de 500 pintainhas que foram aquecidas por lamparinas em virtude da ausência de energia elétrica naquele momento. Eram aves melhoradas geneticamente, destinadas exclusivamente à atividade de postura, pois o aprimoramento genético já havia eliminado o instinto de procriação das galinhas por meio da suspensão do choco. Nesses termos, quando as aves entrassem na fase da postura produziriam ovos ininterruptamente até encerrarem o período produtivo.

O processo produtivo do ovo continuou sequencial, mas com um único ciclo, pois de pintainha a ave tornar-se-ia uma franga e depois uma galinha poedeira sem interrupção da postura até o fim da vida produtiva. Destinada exclusivamente a produção de ovos, essas aves após adquiridas como pintainhas deixam de ser um produto e tornam-se um meio de produção fundamental para a avicultura de postura.

Do ponto de vista da modernização, isso significou incorporar uma inovação técnica, pois aves de postura melhoradas geneticamente tiveram suas características naturais transformadas, almejando produzir mais ovos e em menos tempo. Dessa forma, desde o início da avicultura de postura com fins comerciais, a atividade incorporou uma inovação técnica típica da modernização da agricultura.

Ressalta-se que nessa época, conforme abordado, a modernização da agricultura ainda não havia sido iniciada no Espírito Santo e tampouco em Santa Maria de Jetibá. As condições gerais de produção eram precárias ou inexistentes e desfavoráveis ao desenvolvimento da agropecuária, pois as poucas estradas que davam acesso à Santa Maria de Jetibá não eram pavimentadas e ainda não havia energia elétrica. Nessas condições, embora se usasse uma ave melhorada geneticamente, o padrão tecnológico das granjas era bastante rudimentar.

Essa primeira tentativa de desenvolver a avicultura de postura despertou o interesse de algumas pessoas do distrito de Santa Maria pela atividade. No entanto, entre a precariedade de algumas condições gerais de produção e a existência de muitos gargalos para o desenvolvimento da atividade, a inexistência de indústrias no estado para fabricar a ração era o que mais afetava a expansão da avicultura de postura naquele momento.

Perante tais gargalos, um grupo constituído por vinte empreendedores reconheceu que para desenvolver a avicultura de postura era necessário se 
organizar coletivamente e, oportunamente, fundou em 1964 a Cooperativa de Avicultores - Coopeavi no distrito de Santa Maria. Com a cooperativa foi possível comprar ração em quantidades maiores com preços menores que se comprada individualmente por cada avicultor.

Alguns sócios fundadores não eram avicultores, mas se associaram para constituir o número mínimo de vinte cooperados exigido legalmente para criar uma cooperativa. Dentre os que eram avicultores haviam membros provenientes de famílias de importantes comerciantes locais. Como exemplo, o primeiro presidente da cooperativa, cujo mandato foi de dezenove anos, era comerciante e foi pioneiro na produção de hortaliças, mas não um agricultor familiar; dois sócios fundadores e figuram entre três maiores avicultores atuais, são descendentes de uma família que, por várias décadas, foi proprietária do principal estabelecimento comercial de Santa Maria.

Dessa forma, verifica-se entre esses cooperados iniciais alguns avicultores com mais recursos para investir na atividade, pois no Espírito Santo a produção esteve fortemente subordinada ao comércio, que capturava parte expressiva do excedente produtivo da agricultura, conforme abordado. O coronel não era o fazendeiro, mas o comerciante. Não só os recursos financeiros foram importantes, mas sobretudo a experiência com a atividade comercial vai contribuir para a estruturação de uma cadeia produtiva com menos elos e que tornou a atividade lucrativa, mesmo em um contexto espacial não favorável.

Constituiu-se uma cooperativa justamente no território onde predominam descendentes dos imigrantes pomeranos, caracterizados por serem fechados, reservados e desconfiados, mas que revelaram uma capacidade de se organizarem em prol de interesses econômicos. No entanto, essa organização cooperativa ocorreu entorno da avicultura e não da horticultura que também se encontrava em processo de expansão.

Acrescente-se também que a localização da Coopeavi ocorreu na sede de um distrito em vez da sede municipal. Quando foi fundada a cooperativa, Santa Maria era um distrito pertencente ao município de Santa Leopoldina. A fundação da cooperativa em Santa Maria já dava indícios do poder econômico e político que vinha se constituindo no distrito, que posteriormente, junto com Garrafão, seriam emancipados. 
Por sua vez, o Espírito Santo não tem uma tradição forte de cooperativismo e até a década de 1960 ainda haviam poucas cooperativas no estado. No entanto, entre as décadas de 1960 e 1970, a conjuntura nacional era favorável para a expansão das cooperativas agropecuárias, as quais atuavam como um dos instrumentos da modernização conservadora. Período esse

\begin{abstract}
Que se caracteriza pelo crescimento [das cooperativas agropecuárias], auxiliado por políticas estatais de modernização da agricultura, como a política de crédito subsidiado [...] a grande disponibilidade de crédito possibilitou às cooperativas um período de investimento e crescimento (MEDEIROS; PADILHA, 2014, p.187 e 188).
\end{abstract}

Como um dos instrumentos da modernização conservadora, as cooperativas foram organizadas predominantemente entorno de atividades agropecuárias voltadas para a exportação ou agroindustrializáveis. Mesmo não se encaixando nesse perfil de cooperativas, a Coopeavi teve acesso crédito rural, mas em pequeno volume, até porque seus cooperados iniciais eram proprietários de granjas de pequeno porte. Era essa a dimensão inicial das granjas, pois a avicultura "nasceu pequena" e seu crescimento ocorreu lentamente.

Dois anos após a sua fundação, em 1966, a cooperativa passou a dispor de um armazém onde se vendia aos cooperados milho, produtos avícolas e ração. Como a cooperativa não dispunha de uma fábrica, a ração era comprada em Volta Redonda, no Rio de Janeiro e revendida para os avicultores. A Coopeavi não fornecia as pintainhas e também não comercializava a produção de ovos, que era de responsabilidade de cada avicultor.

No entanto, em 1967, em um terreno cedido, a Coopeavi construiu sua primeira fábrica de ração para atender aos avicultores de Santa Maria. Era uma fábrica de porte pequeno e com uma estrutura de produção muito simples, pois além de não ser balanceada, a ração era produzida em pequena quantidade. Nessa época a avicultura estava em fase inicial e o plantel de aves de postura era bem reduzido, tanto que a produção de milho do estado era suficiente para atender a demanda da atividade.

Mesmo que inicialmente a Coopeavi tivesse tomado pequeno volume de crédito rural, a organização dos avicultores em uma cooperativa facilitava a compra do principal insumo da atividade: a ração. A cooperativa, ao adquirir em volumes maiores a ração pronta ou os ingredientes para sua fabricação, possibilitava reduzir 
o preço desse insumo para o avicultor. Contornava se assim o principal gargalo da atividade, assegurando a oferta de ração a preços menores que se comprada individualmente por cada avicultor.

Desde o início da estruturação da atividade, sempre se buscou estratégias para reduzir os custos de produção. Em 1968, a Coopeavi passou a fazer parte da Central das Cooperativas Agropecuárias do Espírito Santo - Centralcope, localizada em Viana, município da Grande Vitória. Com muito mais recursos e melhor infraestrutura, a Centralcope dispunha de uma fábrica de ração, um abatedouro para a avicultura de corte e também comercializava a produção de ovos. A Centralcope atendia tanto a avicultura de postura quanto a de corte, concentrada em alguns municípios da região serrana do estado.

Todo o montante de recurso da Coopeavi foi investido na Centralcope. Em 1970 a Centralcope entrou em falência e praticamente todo o montante investido pela Coopeavi foi perdido. Usando a pequena fábrica de ração montada em 1967, a Coopeavi seguiu atendendo aos avicultores de Santa Maria após a falência da Centralcope. A importância atribuída à ração deve-se, entre outros aspectos, à sua elevada participação nos custos produtivos da avicultura de postura, sempre superiores a $2 / 3$ do total.

Em 1968, logo após a inauguração da fábrica de ração da Coopeavi, dois cooperados montaram em sociedade uma fábrica própria. Essa fábrica iniciou sua produção com cinco toneladas mensais, suficiente para atender pouco mais de dez mil aves em idade produtiva.

Ocorre que nos anos iniciais da atividade o padrão tecnológico era o mesmo para todos os avicultores e não havia grandes diferenças entre número de aves de cada avicultor. À medida que a avicultura se expande e incorpora progresso técnico a realidade se inverte e essas diferenças assumem dimensão extremamente acentuada.

Nos anos iniciais da avicultura a cooperativa era importante para todos os avicultores, seja como fornecedora de ração, dos insumos para sua fabricação e de informações onde esses insumos pudessem ser adquiridos. Ressalta-se que nessa época o distrito de Santa Maria ainda não possuía uma linha telefônica. Como os 
meios de comunicação eram precários ou inexistentes, o acesso à informação era bastante limitado.

Mas mudanças importantes vão ocorrer a partir de 1976, quando um sócio fundador da cooperativa e representante do distrito de Santa Maria se elege prefeito de Santa Leopoldina. Logo em 1977 a agência do Banestes da sede de Santa Leopoldina foi transferida para a sede do distrito de Santa Maria. Como a agência bancária precisava de um telefone para seu funcionamento, foi, então, instalada a primeira linha telefônica em Santa Maria, que possuía um ramal para atender à cooperativa. Com o telefone a cooperativa encontrava mais facilidades de acesso a informações para obter insumos mais baratos para fabricar a ração.

A eleição de um prefeito que representava os distritos de Santa Maria e Garrafão, expressa o poder econômico e política que se constituiu nesse território. Maiores investimentos foram realizados nesse território e a sede da Santa Maria passou a ter novas funções, pois passou oferecer serviços bancários, dos correios, da cooperativa, entre outros. Como consequência, entre 1970 e 1980 a população urbana dos distritos de Santa Maria e Garrafão saltou de 44 para 1377 habitantes (Tabela), grande parte concentrados em Santa Maria.

\subsection{Incorporação de inovações tecnológicas na avicultura de postura e o processo produtivo do ovo: da pequena produção a produção industrial de ovos}

No decorrer da expansão da avicultura de postura em Santa Maria de Jetibá, dentre as condicionantes que contribuíram para o êxito econômico da atividade, a incorporação de progresso técnico foi um elemento determinante. Embora um número bem reduzido de avicultores tenha incorporado plenamente as inovações técnicas disponíveis, esse pequeno grupo é responsável por mais de 2/3 da produção de ovos. O que ocorreu na avicultura foi uma concentração de capital e, dessa forma, pelo volume de ovos produzidos e não pelo número de avicultores, o que passou a predominar nesse território foi uma moderna produção industrial de ovos.

Um conjunto de inovações técnicas revolucionou e redefiniu o processo produtivo da avicultura, reduzindo a subordinação da atividade à dinâmica da 
natureza e ampliando a valorização do capital, pois "Todo o progresso das técnicas de produção representa antes de mais nada um progresso das técnicas capitalistas de produção, do processo de valorização do capital" (SILVA, 1980, p.31). Isso porque o progresso técnico aumentou a produtividade do trabalho que passou a produzir mais valor, ampliando, dessa forma, a valorização do capital.

Do ponto de vista do processo de produção capitalista, as inovações técnicas são classificadas por Silva (2003) em mecânicas, físico-químicas, biológicas e agronômicas. Num processo constante de valorização do capital, em que medida essas inovações técnicas foram incorporadas na avicultura de postura em Santa Maria de Jetibá, tornando-a uma atividade da agropecuária similar a uma produção industrial.

Considerando a incorporação de novas inovações tecnológicas, as quais promoveram importantes modificações no processo de trabalho da avicultura de postura, identificamos temporalmente três etapas da atividade em Santa Maria de Jetibá. A primeira compreende a década de 1960, quando ocorreu o início da atividade, a segunda inicia-se na década de 1970 até o final dos anos 1990 e a terceira começa no final dos anos 1990 e segue até o presente.

Na primeira etapa a avicultura de postura está se estruturando, mas a cadeia produtiva que vai sendo constituída já apresenta algumas características que vão permanecer nas outras etapas e que ajudam a compreender a expansão da atividade em um contexto não muito favorável.

As pintainhas eram adquiridas das granjas Guanabara e Walkyria. A primeira, localizada no Rio de Janeiro, foi uma referência nacional no melhoramento genético de aves de postura e corte, cujo programa foi incorporado pela Empresa Brasileira de Pesquisa Agropecuária - EMBRAPA, nos anos 1980. A segunda, localizada em Domingos Martins, uma das maiores granjas do Espírito Santo nessa época e que se dedicava à atividade de incubação.

As raças usadas eram a Dekalb e posteriormente a Hy-Line, de linhagens exclusivas para a postura, uma vez que o melhoramento genético alterou as características naturais dessas aves, suspendendo alguns instintos, como o procriativo, para ampliar a produtividade desses animais. Tratava-se, portanto, de uma inovação biológica, por meio da qual 
o homem interfere sobre as determinações da natureza, visando acelerálas ou transformá-las de modo a romper as barreiras que se antepõem ao capital. Assim, uma variedade melhorada geneticamente não é apenas uma planta ou animal capaz de gerar maior volume de produção num menor espaço de tempo ou numa época distinta daquela outra encontrada na natureza. É muito mais do que isso: trata-se de seres "fabricados" pelo capital, que reproduz artificialmente a própria natureza, à sua imagem e semelhança e de acordo com seus interesses (SILVA, 2003, p. 45).

Nessa época já havia no país aves de postura melhoradas geneticamente com elevada capacidade produtiva e desde a o início da avicultura de postura em Santa Maria, houve a plena incorporação das inovações biológicas disponíveis para atividade no país.

O sistema de criação dessas aves compreende três fases: cria, recria e postura. Nas duas primeiras fases ocorre o crescimento corporal das aves. Na cria predomina o crescimento dos ossos e dos músculos. Na recria o crescimento ósseo é reduzido, mas o dos músculos é ampliado e ocorrem os depósitos de gordura. $\mathrm{Na}$ terceira fase a ave atinge a maturidade sexual e inicia a postura dos ovos.

No início dessa etapa não havia distinção na forma de alojar as aves no decorrer das diferentes fases do sistema de criação. As aves permaneciam em um mesmo galpão desde o primeiro dia de vida até o fim do período produtivo. No entanto, ao longo dessa etapa começou a ocorrer a separação das aves. A cria e a recria permaneceram juntas em um mesmo galpão, mas a postura não, ocorrendo a transferência das aves para outro galpão.

A nutrição também não era diferenciada e em todas as fases as aves eram alimentadas com a mesma ração, composta por milho e um concentrado (farinhas ósseas e ingredientes químicos) adquirido da Sadia ou da Anhanguera, que na década de 1960 era uma das maiores empresas de capital majoritariamente nacional ligada à produção de ração animal (SORJ, POMPERMAYER e CORADINI, 1982).

As aves poedeiras eram criadas em galpões fechados de aproximadamente $120 \mathrm{~m}^{2}$, construídos em alvenaria e alambrado, cobertos com telhados de diferentes materiais e com capacidade média de alojamento inicial de 500 aves. Todas as fases do processo de criação das aves ocorriam diretamente sobre o piso que recebia uma cobertura de cepilho ${ }^{9}$ entre 5 e $10 \mathrm{~cm}$, denominada cama. Dentre as funções da

\footnotetext{
${ }^{9}$ Material flexível em forma de tiras ou fitas, com menos de $1 \mathrm{~mm}$ de espessura e produzido a partir de sobras ou pedaços de madeira.
} 
cama pode-se destacar o isolamento térmico entre o piso e as patas das aves e a redução da umidade por meio da absorção da parte líquida do estrume. Ao final do ciclo produtivo a cama era retirada e vendida como esterco para os agricultores, sobretudo aqueles que produziam hortaliças.

Os galpões das granjas possuíam os seguintes equipamentos: comedouros tubulares suspensos onde era depositada a ração; canaletas de bambu que tinham a função de bebedouros; lâmpadas para manter o aquecimento das aves e ninhos de madeira para a postura. Para a coleta dos ovos usava-se cestos de bambu e para acondicionamento caixas de madeira, com divisórias de papelão ou arame.

Na perspectiva do capital, esse padrão tecnológico afetava o desempenho da atividade decorrente de uma série de razões. Em relação à ração, não era possível controlar a quantidade consumida por ave e também havia desperdício, pois como os comedouros eram suspensos, quando as aves estavam se alimentando parte da ração caía sobre a cama. No galpão não havia separação dos ovos e das galinhas como ocorre nas gaiolas. Assim a postura ocorria tanto nos ninhos quanto na cama da granja, o que acarretava em muitos ovos sujos e quebrados, aumentando o trabalho de coleta e limpeza, além das perdas.

Acrescente se também que a criação nos galpões dificultava o controle sanitário, pois as aves tinham contato com fezes, que quando contaminadas desencadeavam algumas doenças provocadas pela salmonela, aumentando a mortalidade das aves.

A postura era iniciada após cinco meses de vida das aves e durava aproximadamente setenta e cinco semanas. Ao longo do ciclo produtivo a capacidade de postura de uma ave era de 180 a 200 ovos, produção essa que demandava o consumo diário de aproximadamente $150 \mathrm{~g}$ de ração por ave.

Todo o trabalho realizado no interior das granjas era manual e exigia a entrada do trabalhador nos galpões para realizar as atividades do manejo das aves. Além disso, o trabalho não era especializado e um mesmo trabalhador realizava diferentes atividades, como coleta e classificação dos ovos, alimentação das aves, limpeza dos equipamentos, acondicionamento entre outras. Constata-se então que o padrão tecnológico empregado e o trabalho não especializado, conferiam ao trabalho baixa 
produtividade, reduzindo a capacidade de acumulação de capital por demandar mais mão de obra.

No entanto, do ponto de vista do bem-estar das aves, esse sistema de produção era mais adequado, sobretudo em relação aos novos padrões produtivos que surgirão posteriormente. Apesar disso, a debicagem, um procedimento de amputação e cauterização de parte do bico da ave usando uma lâmina aquecida, e que é muito criticado em relação ao bem-estar das aves, sempre ocorreu. O objetivo da debicagem é limitar alguns comportamentos do instinto natural das aves e que afetam o desempenho produtivos das aves, como a incidência do canibalismo, a bicagem entre as aves e a quebra dos ovos por bicagem. Além disso, reduz também o desperdício da ração.

Ao final de essa etapa os galpões já alojavam até duas mil aves e os maiores avicultores eram aqueles com mais de dez mil aves. Os maiores avicultores já usavam mão de obra assalariada, embora pela pequena dimensão das granjas fossem contratados poucos trabalhadores. Como a avicultura de postura estava se estruturando, os avicultores deram continuidade às atividades que já desenvolviam, como comerciais e agropecuárias, que contribuíam para o investimento e manutenção da nova atividade.

$\mathrm{Na}$ segunda etapa ocorrem importantes avanços tecnológicos que vão redefinir o processo de trabalho da avicultura de postura. Dentre tais avanços, pela intensidade dos impactos desencadeados na atividade, iniciaremos pela incorporação das inovações mecânicas, as quais "afetam de modo particular a intensidade e o ritmo da jornada de trabalho" (SILVA, 2003, p. 45).

As edificações das granjas passaram a ser constituídas por galpões abertos nas laterais e com telhado coberto sobretudo com telhas de amianto, nos quais foram introduzidas gaiolas metálicas para o confinamento das aves. No início dessa fase em cada gaiola alojava-se três galinhas, mas ao final já eram de seis a oito. Os galpões passaram a ter capacidade para alojar até dez mil aves.

Nesse sistema, também conhecido como californiano, as gaiolas eram dispostas de forma piramidal, geralmente com dois andares e distribuídas em duas fileiras com um corredor de serviço central e nas laterais (Figura 8). O piso era inclinado para que após a postura o ovo deslizasse e se depositasse no coletor 
localizado na parte externa da gaiola. Acima do coletor de ovos e externos às gaiolas, estavam localizados bebedouros de bambu do tipo calha com água corrente e comedouros de madeira do tipo linear. Ainda nessa fase são introduzidos comedouros metálicos e bebedouros tipo nipple (chupeta).

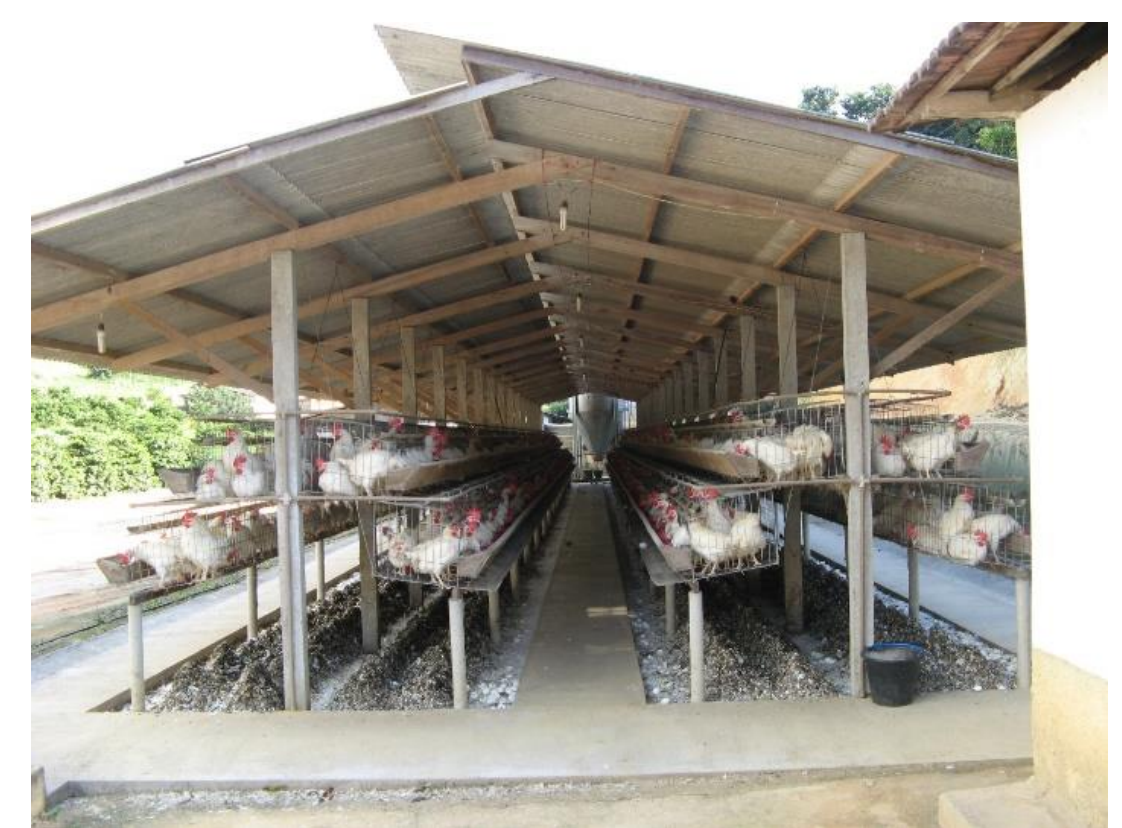

Figura 8 - Granja manual - Granja que permaneceu com padrão tecnológico do início da segunda etapa da avicultura de postura, como as gaiolas piramidais e com dois andares, os comedouros em madeira e todo o processo produtivo manual.

O sistema de produção baseado no confinamento e na disposição piramidal das gaiolas possibilitou as seguintes melhorias para a avicultura de postura: alojamento de mais aves em menos espaço físico; redução da mortalidade das aves pelo contágio de doenças; a deposição dos ovos nos coletores da gaiola reduziu em $10 \%$ as perdas por quebras e reduziu o tempo de trabalho com a coleta; os comedouros lineares facilitaram o abastecimento de ração e também reduziram o tempo de trabalho; os bebedouros de água corrente eliminaram a necessidade de mão de obra para o abastecimento, embora aumentaram o desperdício desse recurso natural.

Embora esse sistema de produção reduza o bem-estar das aves, para o capital permitiu ampliar sua capacidade de reprodução. As mudanças promovidas pela inovação mecânica em questão, aumentaram a produtividade do trabalho e consequentemente reduziram o emprego de mão de obra. Em outras palavras, a 
incorporação de tecnologia possibilitou ampliar a exploração da mais-valia relativa. Apesar dos avanços nas inovações mecânicas, o trabalho continuou sendo realizado manualmente, inclusive na classificação dos ovos. A única mudança que ocorreu nessa última etapa do processo produtivo do ovo foi a introdução das bandejas de papelão com capacidade para 30 ovos.

Por sua vez, as inovações físico-químicas "modificam as condições naturais do solo, elevando a produtividade do trabalho aplicado a esse meio de produção básico e reduzindo as "perdas naturais" do processo produtivo" (SILVA, 2003, p. 45). No entanto, para a avicultura de postura, diretamente o solo não é um meio de produção, mas somente um substrato para a localização da granja. O solo é um meio de produção indireto, pois nele se produz insumos usados na alimentação das aves. Considerando essa particularidade e a descrição apresentada por Silva (2003), na avicultura de postura as inovações físico-químicas correspondem aos produtos químicos (desinfetantes), farmacêuticos (vacinas) e à nutrição das aves (rações balanceadas).

Tais inovações, apresentam mudanças marcantes nas áreas de nutrição e sanidade na segunda etapa da avicultura de postura. Em relação à nutrição, a ração passou a ser mais balanceada e diferenciada em cada fase do ciclo produtivo. Além do milho, que já era usado na ração desde a fase anterior, foram introduzidos o farelo de soja e um premi $x^{10}$ composto por minerais e vitaminas adequados para cada fase das aves. A principal consequência do avanço nutricional foi a redução do consumo de ração, devido a ampliação da capacidade de conversão alimentar, ou seja, da ave converter a ração ingerida em ovos. Considerando a fase da postura, do início para o final da segunda etapa, o consumo de ração foi reduzido de 140 gramas diárias por ave para 120 gramas.

No que tange à sanidade, após a troca de cada lote de aves nas diferentes fases do ciclo produtivo, os galpões das granjas eram desinfetados. A partir da década de 1980, foram introduzidas as vacinas no manejo das aves de postura, "cuja exposição às doenças se prolonga durante um ciclo muito mais longo que o da criação de frangos" (MARTINS, 1996, p. 105).

\footnotetext{
${ }^{10}$ Mistura de micronutrientes essenciais para o melhor desenvolvimento e maior produtividade animal. Dessa forma, o premix é elaborado de acordo com as necessidades nutricionais de cada tipo de animal.
} 
As duas medidas adotadas reduziram a manifestação de doenças e a mortalidade, que oportunamente aumentou a produtividade das aves. Para o capital, o uso dessas inovações elevou também a produtividade do trabalho aplicado na avicultura e, considerando que somente o trabalho produz valor, esse trabalho mais produtivo ampliou a valorização do capital na avicultura de postura.

Acerca das inovações biológicas também são verificados importantes avanços tecnológicos. Pelo desempenho produtivo a linhagem $\mathrm{Hy}$-Line se generaliza na avicultura de postura de Santa Maria de Jetibá. O contínuo melhoramento genético dessa linhagem reduziu em aproximadamente quinze dias a duração das fases da cria e recria que passou de cinco meses para quatro meses e meio. Ao mesmo tempo a fase da postura foi ampliada em cinco semanas, passando a ter duração de oitenta semanas.

De um lado houve uma redução no tempo de produção, pois a postura foi iniciada mais cedo e de outro uma extensão do período produtivo da ave, pois a fase da postura foi ampliada. Apesar desses avanços, o tempo que a galinha leva para produzir um ovo permaneceu o mesmo, que é de aproximadamente vinte e cinco horas. O melhoramento genético não alterou essa característica das galinhas poedeiras, pois nem sempre o capital consegue romper todas barreiras impostas pela natureza à sua reprodução.

Articuladas, essas inovações possibilitaram ganhos elevados de produtividade. O melhor controle da alimentação pelo confinamento em gaiolas permitiu, a ração mais balanceada e a extensão do período de postura, elevaram a produção de ovos por ave para até duzentos e setenta ovos, em contraposição com os duzentos da etapa anterior. Numa relação inversa, o consumo de ração por ave foi reduzido, mas a produção de ovos por ave foi ampliada.

Nessa etapa já se manifestam importantes diferenças entre os avicultores, segundo o porte das granjas. Na década de 1980, em Santa Maria de Jetibá era considerado de porte grande, granjas que alojavam mais de vinte mil aves, mas somente cinco avicultores possuíam planteis nessas proporções, segundo o IJSN (1983). No entanto, ao final dessa etapa, os maiores avicultores eram aqueles com mais de cento e cinquenta mil aves. 
Outro aspecto que diferencias os avicultores são as relações de trabalho. Enquanto os pequenos avicultores contam somente o trabalho familiar, os de porte grande usam somente mão de obra assalariada, restringindo o trabalho da família à gestão do negócio.

Sempre constituído por um número muito reduzido, os maiores avicultores deixam de depender da cooperativa para adquirir a ração, pois montam suas próprias fábricas e passam também a comercializar esse produto. Desde a década de 1980 os grandes produtores passaram a comprar as matérias-primas da ração na região Centro-Oeste e posteriormente no Triângulo Mineiro, uma vez que possuíam caminhões para fazer o transporte dessas cargas. Ao se organizarem para comprar insumos da ração, os avicultores de porte grande vão criando alternativas para reduzir custos de produção e se manterem competitivos no mercado.

Os pequenos e médios seguem dependendo da cooperativa para a aquisição tanto da ração quanto das aves. Em 1974 a Coopeavi inaugura uma granja de cria e recria e passa a oferecer um novo produto aos cooperados: frangas com noventa dias. A cooperativa internalizou as duas primeiras fases do processo de criação das aves, quando o manejo é mais complexo, pois a mortalidade é maior, é aplicada a maior parte das vacinas e ocorrem as duas etapas da debicagem.

Especialmente para os pequenos avicultores, que trabalham em bases familiares e com menos infraestrutura nas instalações das granjas, é mais oportuno especializar-se somente na fase da postura. De um lado, trabalhar com as três fases da criação é mais complexo, pois cada uma delas requer um manejo específico e diferentes espaços para alojamento das aves. Mas de outro lado, o avicultor tornase mais dependente da cooperativa e paga pela franga um valor bem superior ao de uma pintainha.

Na década de 1980 cento e vinte sócios da cooperativa eram avicultores, segundo o IJSN (1983). Isso significa que a atividade estava se expandindo progressivamente e nesse momento, além do Espírito Santo não produzir soja, um novo ingrediente adicionado à ração, a produção de milho do estado não era mais suficiente para atender a demanda da atividade.

Ocorre que os principais produtores das matérias-primas de maior peso na composição da ração, o Centro-Oeste e o Triângulo Mineiro, estão localizados a mais 
de 1000 km de distância de Santa Maria de Jetibá, o que torna o custo de produção "cerca de 17\% maior que em outros estados, devido principalmente ao abastecimento do milho, ao considerar que o estado do Espírito Santo produz somente 5\% dos insumos necessários para a produção de ração" (COVRE, 2010, p.16). Nessas condições, somente via cooperativa ou estruturando uma cadeia produtiva verticalizada e com vários elos dominados pelos avicultores, tanto a montante quanto a jusante, para tornar a atividade competitiva.

Por fim, na terceira etapa da avicultura, que se inicia em 1998 e segue até o presente, a incorporação tecnológica ocorre em intensidade muito maior em relação às etapas anteriores, redefinindo todo o processo de trabalho da atividade. Nessa etapa ocorre a reestruturação produtiva e a avicultura se consolida como

a atividade que possui o maior e mais avançado acervo tecnológico dentre o setor agropecuário brasileiro. Os grandes progressos em genética, nutrição, manejo e sanidade verificados nas últimas quatro décadas transformaram o empreendimento num verdadeiro complexo econômico, traduzido por uma grande indústria de produção de proteína de origem animal (TINÔCO, 2001, s.p,).

Além dos avanços mencionados por Tinôco (2001), acrescente-se também a guinada tecnológica ocorrida nas inovações mecânicas, comandada pela automação de todo o ciclo produtivo da avicultura de postura. De todas a inovações incorporadas, a que mais impactou a avicultura de postura em Santa Maria de Jetibá foi a automação das granjas de porte grande, pois todo o processo produtivo da atividade foi reestruturado e as demais inovações potencializadas.

Foram automatizados o arraçoamento, a coleta dos excrementos das aves, a coleta, a classificação e o empacotamento dos ovos. Isso significa que todas essas atividades anteriormente executadas de forma manual, passaram ser realizadas por máquinas automáticas controladas por computadores, possibilitando o maior controle do processo produtivo e a redução drástica de mão de obra. A automação não se restringiu somente à postura, mas se estendeu às demais fases da criação, conforme pode ser verificado nas figuras 9 e 10 . 


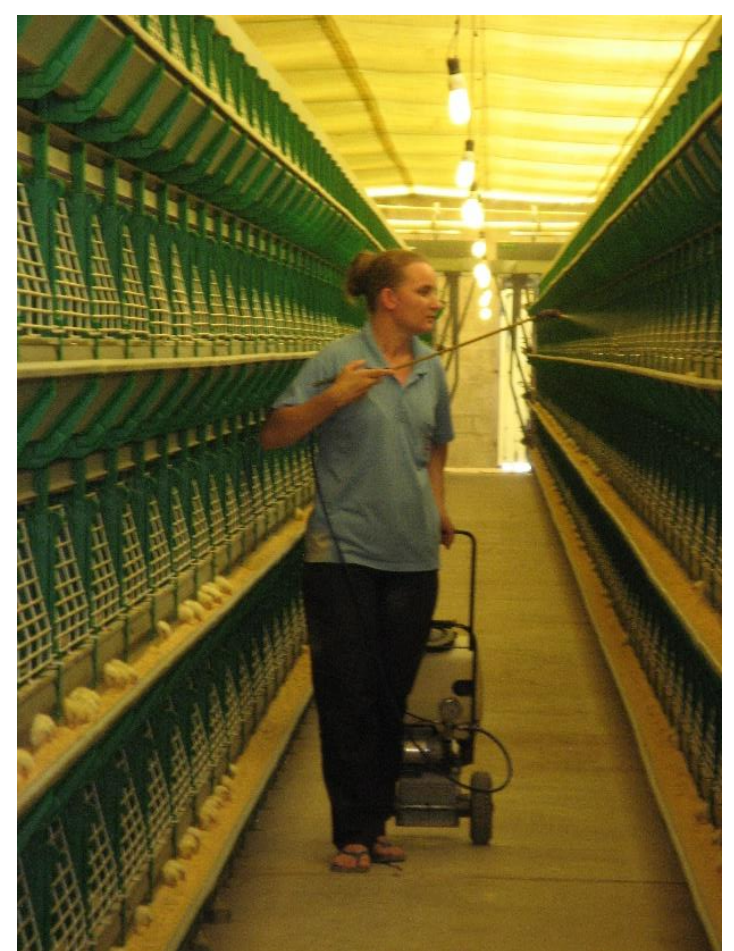

Figura 9 - Galpão de cria automatizado e vacinação das pintainhas.

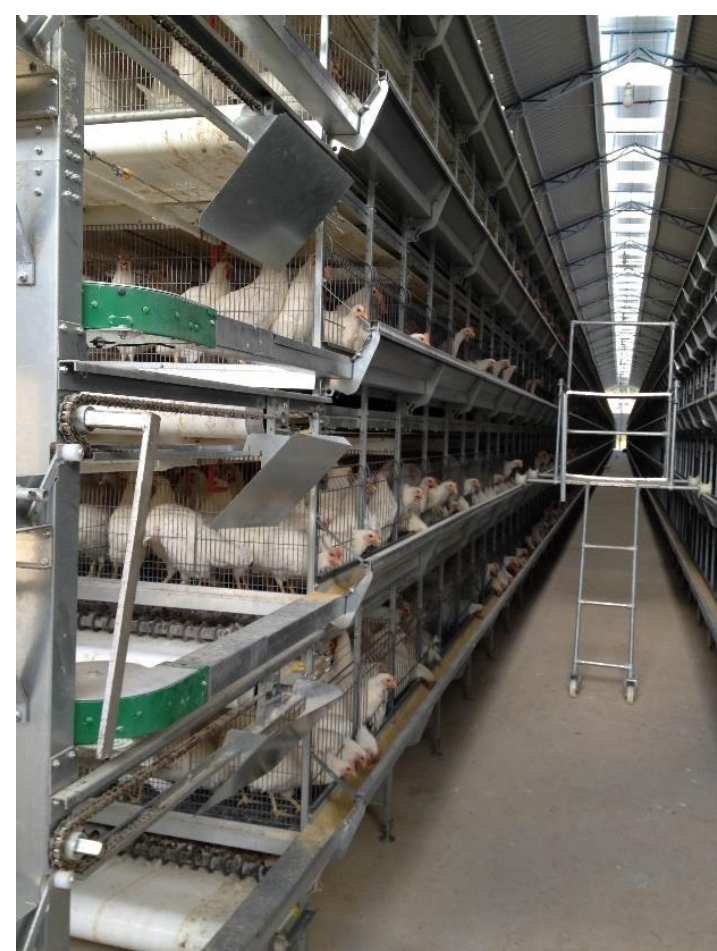

Figura 10 - Galpão de recria automatizado.

A única exceção refere-se à climatização dos galpões das granjas, os quais são abertos e, portanto, não permitem controle da temperatura e da umidade. Somente os galpões de cria são fechados e a temperatura é controlada, pois nessa fase é fundamental que as pintainhas sejam aquecidas. A climatização pode elevar a produtividade das aves de postura em até $10 \%$, mas em função da altitude as condições de temperatura de Santa Maria de Jetibá são extremamente favoráveis à atividade.

Embora em alguns períodos do ano, sobretudo no verão, durante o dia a temperatura se eleva um pouco mais, provocando o estresse das aves que acabam ingerindo menos ração. No entanto, à noite, a queda da temperatura compensa o estresse diário e a ave volta a se alimentar, afetando bem menos a produtividade.

Acerca das edificações das granjas, ocorreu importante evolução. Os galpões são construídos em alvenaria e estruturas metálicas, com piso de concreto e pé direito acima de cinco metros devido a verticalização das gaiolas. Os telhados são cobertos por materiais que oferecem conforto térmico adequado para assegurar elevados níveis de produtividade das aves. Durante à noite a iluminação também é controlada, para aumentar a produtividade das aves. 
Por sua vez, a verticalização das granjas permitiu que a disposição das gaiolas fosse ampliada para até oito andares, que atingem mais de cinco metros de altura e, assim, um único galpão tem capacidade para alojar até 250.000 aves. As gaiolas foram ampliadas e alojam até 12 aves. Nessas condições técnicas, à medida que a atividade se expandia, a demanda de área por ave ia sendo reduzida, sem interferir na estrutura fundiária. Lembrando que a terra é somente um substrato para a avicultura de postura comercial.

Nesse sistema de gaiolas, o arraçoamento das aves é realizado por máquinas tratadoras automatizadas, compostas por uma caçamba que recebe a ração e a distribui por meio de mangueiras com bicos dosadores. Esses tratadores, programados e acionados automaticamente, movimentam-se horizontalmente em toda a extensão das gaiolas, abastecendo uniformemente os comedouros com ração. A distribuição da ração é realizada várias vezes ao longo de um dia, mas em quantidade ideal para que a ave produza um ovo, reduzindo o desperdício desse insumo, que tem o maior peso no custo de produção da avicultura de postura.

Além da ração, outra importante fonte de nutrientes é a água. Por isso é importante fornecê-la com qualidade adequada para que não se torne um meio de contaminação das aves. Normalmente as grandes granjas usam água de poços artesianos, que é capitada, armazenada em reservatórios e depois fornecida às aves em bebedouros tipo nipple (chupeta).

Esse tipo de bebedouro reduz o risco de contaminação e também elimina totalmente o desperdício, pois é acionado pelo bico da ave e libera somente a quantidade de água que será consumida. É também por meio da água fornecida por esses bebedouros que ocorre a vacinação via oral das aves.

Em relação ao esterco, a coleta é realizada por cintas de polipropileno, localizadas embaixo de cada andar de gaiolas, abrangendo toda sua extensão, que recebem os excrementos das aves. Duas vezes por semana essas cintas são colocadas em movimento, levando os excrementos para transportadoras transversais inclinadas, as quais depositam esses resíduos em caçambas de caminhões. Assim, os excrementos são retirados das granjas e levados para galpões, onde recebem um tratamento antes de serem comercializados.

Essa frequência de coleta dos excrementos reduz a infestação de moscas e o odor das granjas, facilitando o controle sanitário. Mas, por outro lado, o esterco produzido por essas granjas automáticas tem qualidade bastante inferior ao das que 
permanecem em sistemas manuais e a retirada dos excrementos é anual. Apesar disso, é um subproduto da avicultura e que tem valor comercial.

Por sua vez, em relação aos ovos, um sistema integrado de equipamentos realiza automaticamente a coleta desse produto, sem haver nenhum contato manual. Após a postura os ovos deslizam pelo piso inclinado das gaiolas até as esteiras coletoras, que transportam os mesmos até os descedores verticais de ovos (Figura 11). Após passarem pelos descedores os ovos são recolhidos por uma esteira que os transporta até a sala de classificação. Esse sistema de esteiras reduz perdas, pois previne o amontoamento dos ovos, diminuindo as possibilidades de ocorrerem trincas.

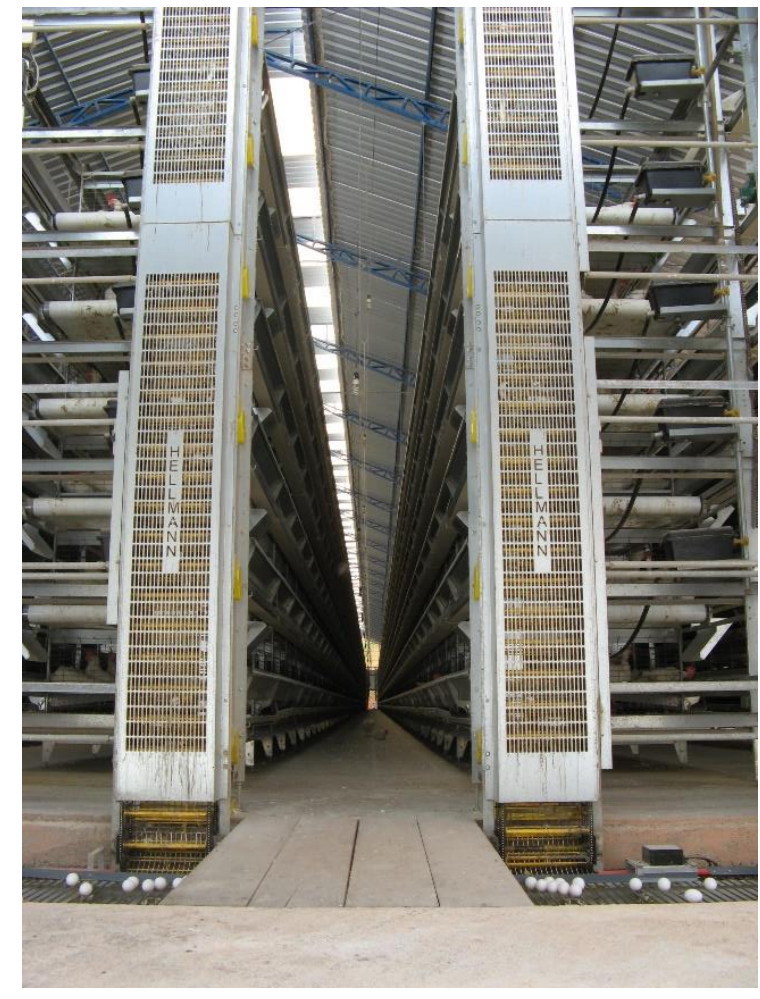

Figura 11 - Descedores verticais de ovos.

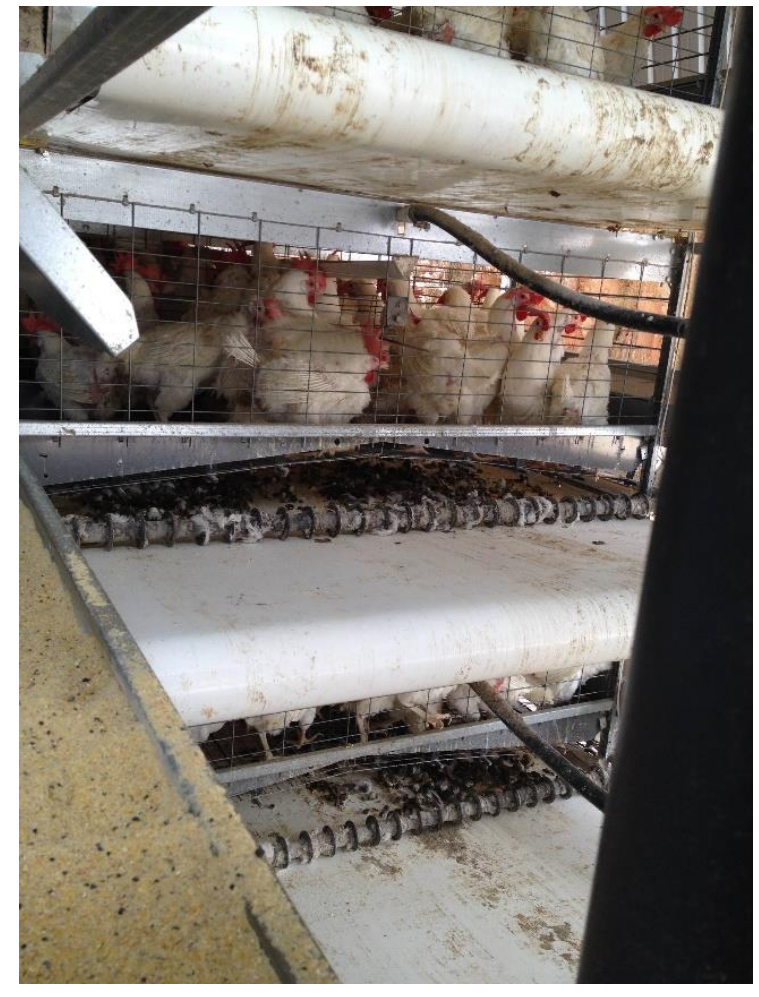

Figura 12 - Cintas coletoras de esterco.

Embora essas inovações mecânicas tenham redefinido o processo produtivo da avicultura de postura, reduzindo significativamente os custos de produção e elevando a produtividade do trabalho, o conjunto de tecnologias aplicado na automação das granjas não é complexo. Grande parte das granjas automatizadas usa equipamentos importados, sobretudo da Europa, mas cuja manutenção é realizada por eletricistas e mecânicos, sem demandar profissionais com elevado nível de qualificação. 
Diferentemente, a tecnologia das máquinas e equipamento usados na classificação automática dos ovos é bem mais complexa. As empresas produtoras de tais máquinas e equipamentos realizam manutenções anuais, com profissionais especializados.

Após serem transportados até a sala classificadora, primeiramente os ovos são inspecionados por equipamentos que detectam trincas, sujidades e a presença de sangue. Alguns equipamentos eliminam automaticamente os ovos que apresentam problemas, enquanto outros requerem a retirada manual. Em seguida os ovos sem problemas continuam seu percurso, são classificados por peso ${ }^{11}$ e de acordo com o resultado da classificação, direcionados para as diferentes embaladoras e acondicionados em bandejas de papelão. Por fim, essas bandejas seguem até o fim das embaladoras onde são transferidas manualmente para caixas de papelão, com capacidade para receber 12 bandejas (Figuras 13 e 14). Por meio de uma esteira essas caixas são transportadas para a sala de expedição e no máximo 24 horas após a postura o ovo já está disponível para o consumidor.

A classificação e o empacotamento dos ovos são atividades da avicultura que quando realizadas automaticamente, o ritmo do trabalho é controlado pela máquina. Embora não se esteja fabricando um produto, apenas classificando e empacotando, essas atividades são semelhantes a de uma linha de produção industrial.
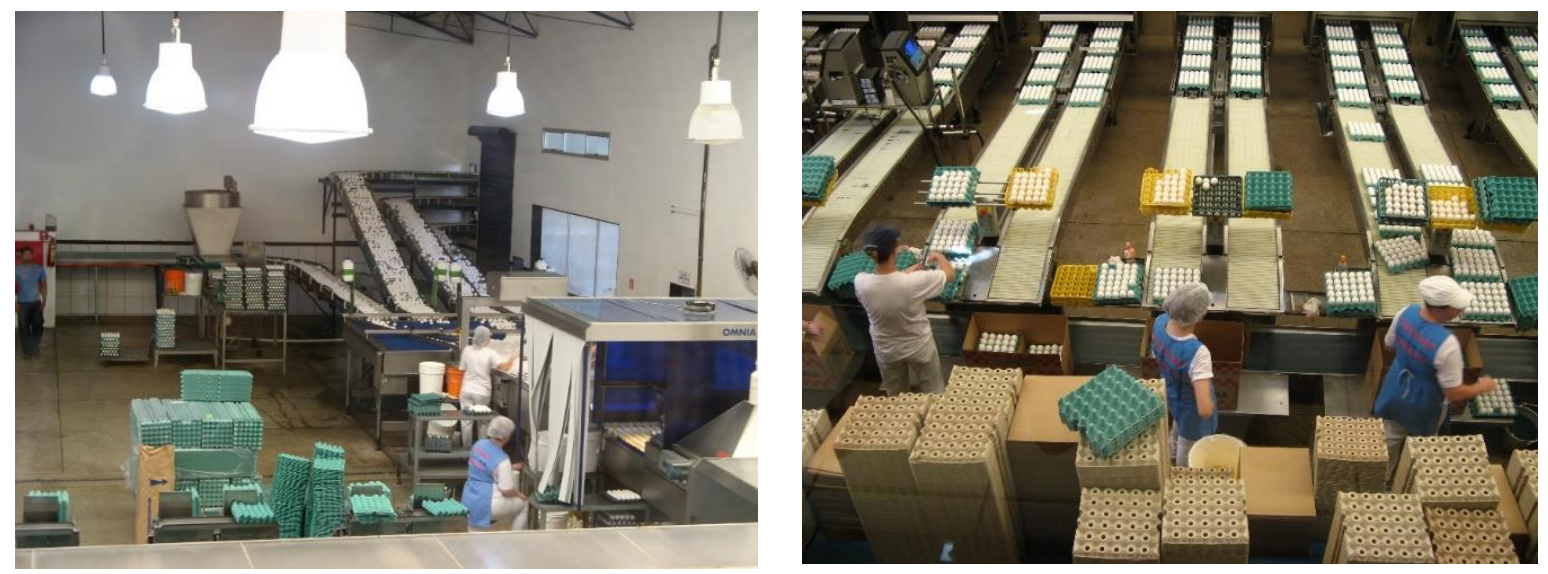

Figuras 13 e 14 - Classificação e empacotamento dos ovos.

Nesse contexto de intensos avanços tecnológicos é importante considerar que o produto da avicultura de postura, o ovo, não é produzido diretamente pelo trabalho

11 Os ovos são classificados por peso e agrupados em quatro classes: pequeno, médio, grande e extragrande. 
humano e nem pelas máquinas automáticas, pois depende essencialmente de um elemento vivo: a ave. Sendo assim, a separação do trabalho e do conhecimento ocorrida na indústria com a introdução das máquinas, manifesta-se forma diferente na avicultura de postura, quando essa atividade é automatizada. Decorrente da introdução da máquina na indústria

\begin{abstract}
o trabalho tornou-se uma mera ação mecânica e a ciência se colocou fora da subjetividade de quem trabalha; foi pensada em outro local e, no processo de trabalho, encontra-se presente não em quem trabalha, mas dentro de uma coisa, pois é isso que é a máquina. Essa será a característica central do processo de produção enquanto ele for determinado pelo capital (NAPOLEONI, 1981, p. 93).
\end{abstract}

$\mathrm{Na}$ avicultura de postura a aplicação de conhecimento nas inovações incide sobre a máquina, mas também se estende ao melhoramento genético, à nutrição e à sanidade das aves. Esse conhecimento é produzido em centros de pesquisa, portanto, fora da granja, mas está presente "nas coisas" da granja, em outras palavras, nas inovações mencionadas e que são empregadas na avicultura de postura. No entanto, tanto antes quanto após a incorporação de tais avanços tecnológicos, o conhecimento não estava presente na figura do trabalhador e, dessa forma, o nível de qualificação desse sujeito social permaneceu o mesmo.

O ovo, produto final da avicultura de postura, não é produzido diretamente nem pela máquina e nem pelo trabalho humano, mas pela galinha. Dessa forma, o conhecimento incide diretamente sobre a ave, por meio do melhoramento genético, nos insumos usados por esse elemento vivo, como a ração e os fármacos e também nas máquinas automáticas. Inovações essas, que incorporadas de forma articulada se potencializam e elevam a produtividade da avicultura de postura.

Guardadas as devidas particularidades de uma atividade que depende de um elemento vivo em seu processo produtivo, é importante salientar que nessa última etapa a avicultura de postura assumiu algumas características da produção industrial. Apesar disso, a avicultura permanece como uma atividade da agropecuária, pois o centro do seu processo produtivo está assentado em um elemento vivo.

E é exatamente esse elemento vivo que vem sendo, de forma progressiva, melhorado geneticamente por meio das inovações biológicas. Novas linhagens de postura continuam sendo desenvolvidas, gerando aves cada vez mais produtivas e 
menos consumidoras de ração, mas que requerem uma nutrição muito mais balanceada e maior controle fitossanitário.

No entanto, esses avanços genéticos nas aves de postura, praticamente não são desenvolvidos no país e, assim, a atividade depende de inovações biológicas produzidas no exterior, pois

\begin{abstract}
Em aves poedeiras, a não ser pelos programas de pesquisas ainda em andamento na UFV e o de obtenção de linhagens comerciais de ovos brancos e vermelhos da EMBRAPA, a dependência do Brasil de genética produzida no exterior é praticamente $100 \%$. Pouca atenção foi dada ao programa de melhoramento genético de poedeiras por atender apenas o mercado interno de consumo e provavelmente pelo prestígio do setor de frango de corte que rapidamente atingiu o mercado externo, de forma competitiva (SILVA, 444, 2009).
\end{abstract}

Embora o país já esteja exportando ovos, o volume ainda é insignificante. Seguindo a tendência predominante no país, a avicultura de postura em Santa Maria de Jetibá é totalmente voltada para o mercado interno e dependente sobretudo da genética produzida pela multinacional estadunidense Hy-Line, cujas linhagens prevalecem quase absolutamente entre os avicultores.

A cada nova linhagem lançada no mercado, a Hy-Line disponibiliza manuais de manejo que orientam todo o processo de criação da ave, do primeiro dia de vida da pintainha ao último dia de postura da galinha. São orientações que preconizam o uso intensivo e articulado de um conjunto de inovações para que as aves alcancem a produtividade propagada pela empresa.

Por sua vez, nessa etapa da avicultura de postura, as três fases da criação ocorrem em galpões separados e todos são automatizados. A duração das duas primeiras fases foi reduzida para 3,8 meses e a postura ampliada para até 120 semanas, caso a muda forçada seja praticada. Nessas condições de manejo, a produção de ovos pode atingir até 500 unidades por ave. No entanto, o tempo que a galinha leva para produzir um ovo permanece o mesmo: 25 horas.

A muda forçada é um procedimento realizado em galinhas de postura e tem como objetivo estender o ciclo produtivo. Entre a $65^{\mathrm{a}}$ e a $75^{\mathrm{a}}$ semana de vida a galinha é submetida a um período de restrição alimentar e hídrica que pode se estender por até 15 dias. A falta de alimentos e água provoca um desequilíbrio da hormonal e ocorre uma regressão do aparelho reprodutivo da galinha. Em outras palavras, a galinha volta a ser uma franga e inicia uma nova fase de postura. 
Normalmente as aves também perdem as penas, quando submetidas às restrições em questão.

Embora seja uma prática bastante criticada em relação ao bem-estar das aves, a muda forçada sempre foi um procedimento empregado na avicultura de postura em Santa Maria de Jetibá. O que motiva a decisão do avicultor em praticar ou não a muda forçada é um critério meramente econômico. Considera-se os custos de produção e o preço do ovo e se o resultado for atrativo em termos financeiros, pratica se a muda forçada.

Outra prática também criticada é a debicagem, mas esse procedimento vem sendo realizado a laser. As pintainhas com um dia de vida são debicadas no incubatório e a parte do bico que recebeu o raio infravermelho cai com aproximadamente duas semanas. Essa técnica é menos agressiva e torna desnecessária a segunda debicagem, que ocorria anteriormente quando era realizada por lâminas.

Em relação às inovações físico-químicas, verifica-se que por meio de rações adequadamente balanceadas, a nutrição das aves evoluiu até atingir a dieta ideal. Diariamente, na fase da postura, a ave consome 80 gramas de ração, menos que as 98 gramas recomendadas pelo manual de manejo da Hy-Line (2015). A redução da quantidade necessária para a postura de um ovo a cada 25 horas, foi possível porque em Santa Maria de Jetibá conseguiram chegar a uma dieta ideal

\footnotetext{
O requisito nutricional para as aves é muito mais conhecido do que para qualquer outro animal doméstico. As rações são cientificamente balanceadas para assegurar a saúde das aves poedeiras, bem como a produção de ovos de ótima qualidade a um custo baixo (EMBRAPA, 2004 p. 16).
}

Essa ração balanceada é composta por milho, farelo de soja e um premix de minerais, vitaminas e aminoácidos, cujas proporções são diferenciadas em cada fase da criação das aves e também no decorrer da postura. Além do balanceamento, para evitar poeiras e desperdício, foram definidos padrões de granulometria da ração. Para atender aos requisitos nutricionais e granulométricos da ração, as fábricas são automatizadas.

Também ocorreram importantes avanços no controle das doenças e os avicultores seguem regras estabelecidas pelo Programa Nacional de Sanidade 
Avícola, instituído pelo Ministério da Agricultura desde 1994. O avicultor não tem que seguir tais regras somente para evitar a contaminação de suas granjas, mas também das localizadas mais próximas.

As granjas têm programas de limpeza e desinfecção de suas instalações, controle da qualidade da água e ração, controle de entrada de pessoas e veículos com procedimentos de desinfecção e um programa de vacinação, no qual a ave recebe quase 30 doses de vacinas, ministradas principalmente nas fases da cria e recria. O relevo de Santa Maria de Jetibá sempre favoreceu o controle sanitário, pois naturalmente as serras isolam e contribuem para proteger as granjas da proliferação de doenças.

Acerca da evolução tecnológica apresentada, algumas considerações são necessárias para melhor compreender suas manifestações em Santa Maria de Jetibá. Primeiramente, apresentou-se o padrão tecnológico predominante na avicultura de postura, ou seja, aquele responsável por grande parte da produção de ovos. Segundo a secretaria municipal de agricultores, o município possui 132 avicultores, dos quais apenas sete respondem por aproximadamente $80 \%$ da produção de ovos. Embora sejam dados estimados, traduzem bem a realidade da avicultura do município.

Em segundo lugar, à medida que se intensifica o avanço tecnológico da avicultura de postura, maiores são as diferenças entre as granjas. Independente da dimensão das granjas, algumas inovações são incorporadas por todos os avicultores, como as biológicas e as físico-químicas, mas as mecânicas não.

Dos pequenos aos grandes avicultores, todos usam as mesmas linhagens de aves melhoradas geneticamente e rações balanceadas. No entanto, os pequenos avicultores e que trabalham em bases familiares de produção, avançaram muito pouco em relação às inovações mecânicas. A automação das granjas, que vai reestruturar o processo produtivo da avicultura de postura e potencializar os avanços das demais inovações, ainda é pouco incorporada pela maioria dos avicultores. Aqueles avicultores com planteis acima de 20 mil aves começam a automatizar o arraçoamento, que requer investimento menor. No entanto, tanto a coleta do esterco e dos ovos, quanto o processo de classificação e empacotamento dos ovos permanecem manuais. 
Da mesma forma que na produção agrícola, conforme será abordado no próximo capítulo, na avicultura de postura a incorporação de inovações mecânica esbarra na escala de produção. A automação plena ainda não é viável em granjas de porte pequeno, pois as máquinas e equipamentos são produzidos para granjas de porte médio à grande. Dessa forma, pelos investimentos requeridos, a avicultura de pequeno porte tem capacidade reduzida de se automatizar.

Com a automação das granjas de porte grande, reduziu a demanda de trabalhadores. Antes da automação, excluindo a classificação dos ovos, era necessário um trabalhador para cada 10 mil aves, com a automação o número de aves por trabalhador é ampliado para 100. A avicultura de postura automatizada, considerando somente a atividade de produção e classificação dos ovos, apresenta reduzida capacidade de geração de emprego.

Discorridas as três etapas da evolução técnica da avicultura de postura, verifica-se que os insumos e meios de produção da atividade foram desenvolvidos com elevado nível de conhecimento científico. Mas esses insumos e meios de produção foram produzidos distantes das granjas, muitos deles fora do país e a avicultura é somente uma incorporadora de tecnologias. Apesar de todos os avanços tecnológicos, o produto da avicultura de postura comercial permanece com as mesmas características. Desde quando a atividade foi introduzida em Santa Maria de Jetibá até o presente, os insumos e meios de produção foram intensamente modernizados, mas o ovo produzido ainda é o mesmo.

\subsection{A estruturação da cadeia produtiva da avicultura de postura e as principais condicionantes do êxito econômico da atividade}

Considerando a classificação das inovações proposta por Silva (2003), as agronômicas são aquelas que "permitem novos métodos da organização da produção através da recombinação dos recursos disponíveis, elevando a produtividade global do trabalho de um dado sistema produtivo, sem a introdução de novos produtos e/ou insumos" (SILVA, 2003, p. 44). Transpondo essa caracterização para a avicultura de postura, Santa Maria de Jetibá foi desenvolvedora de uma 
inovação agronômica ao estruturar uma cadeia produtiva altamente verticalizada para superar desvantagens locais e conferir a atividade caráter competitivo.

Poucos anos após a introdução da avicultura de postura, a obtenção dos principais componentes da ração já era o principal gargalo da atividade. A produção estadual de milho não era mais suficiente para atender a demanda da atividade $e$ em relação à soja, a cultura não era produzida no Espírito Santo. Nessa época as vias de acesso ao território de Santa Maria de Jetibá ainda não eram pavimentadas, a energia elétrica havia acabado de ser instalada, mas somente na sede, e não havia sequer uma linha telefônica. É importante reafirmar que em 1970 a população da sede do distrito de Santa Maria contava com somente 44 habitantes (tabela 13).

Perante a precariedade dos meios de circulação e comunicação, o acesso a informações sobre a oferta dos componentes da ração era limitado. A primeira alternativa foi criar a Coopeavi, pois por meio da cooperativa era mais fácil obter informações acerca dos locais onde havia produção e oferta das matérias-primas da ração, além do que, também havia crédito rural para esse tipo de organização. Nesse momento, a organização dos avicultores em uma cooperativa foi fundamental para o início da atividade.

Em 1970 a modernização da agricultura estava se iniciando no Espírito Santo e nesse momento a política oficial de crédito rural do país dispunha de grandes volumes de recursos, os quais eram concedidos a taxas de juros altamente subsidiadas e com longos prazos para pagamento. Apesar disso a avicultura de postura não se expandia em ritmo acelerado. A maior produção estadual de ovos estava concentrada no município de Domingos Martins (Censo Agropecuário, 1970) e ainda não havia uma grande demanda de consumo pelo produto da avicultura de postura.

É importante considerar que até 1970 a população do Espírito Santo ainda era predominantemente rural e, considerando a estrutura fundiária estadual, grande parte dessa população produzia de forma direta os meios de vida. Além disso, o principal mercado consumidor da produção de ovos de Santa Maria de Jetibá estava concentrado na Grande Vitória, cuja população era de somente 385.998 habitantes (tabela 12). Em outras palavras, o mercado consumidor ainda era restrito. 
Por sua vez, havia também entre os sócios fundadores da cooperativa, alguns avicultores que desenvolviam atividades comerciais e cujas famílias se destacavam como importantes comerciantes naquele território. Eram as tradicionais vendas que realizavam duplo comércio, tanto comprando a produção dos agricultores, quanto Ihes vendendo uma ampla gama de mercadorias para atender às suas necessidades. É importante reafirmar que dada as características da estrutura produtiva do Espírito Santo, o coronel não era o fazendeiro, mas sim o comerciante.

A experiência adquirida nas atividades do comércio contribuiu para que esses avicultores tivessem mais facilidades tanto nas negociações envolvidas na compra da matérias-primas da ração, quanto na comercialização dos ovos produzidos. Ressalta-se também que esses avicultores apresentavam nível de escolarização bem superior à média da população de Santa Maria de Jetibá e ainda havia entre eles um que atuou como representante da empresa Purina entre as décadas de 1970 e 1990.

$\mathrm{Na}$ década de 1970 esses avicultores realizaram as primeiras viagens técnicas para o exterior com o intuito de visitar feiras e exposições internacionais que apresentam inovações voltadas para a avicultura de postura. As visitas a esses eventos se intensificaram ao longo dos anos, com destaque para os avicultores que participam frequentemente dos principais eventos voltados para a atividade. São eventos que ocorrem sobretudo nos Estados Unidos e em países da Europa e da Ásia que se destacam no desenvolvimento de tais inovações.

No âmbito nacional também foram realizadas viagens, mas com outros fins. Os avicultores de porte maior já haviam montado fábricas próprias de ração e, oportunamente, iniciaram na década de 1980 as primeiras viagens para o CentroOeste, com intuito de estabelecer contratos para aquisição de milho e farelo de soja. Para tanto, recorreram ao crédito rural, embora os avicultores de porte maior não recorram muito ao financiamento da atividade. Nessa década a política creditícia tenha sido afetada pelo momento econômico recessivo do país, e por isso ocorreu redução significativa do volume de recursos e dos subsídios, pois

Com a recessão que atinge a economia brasileira nos anos 1980, em função principalmente da crise da dívida externa, o governo perde sua capacidade de continuar assistindo a agricultura com injeção de recursos públicos, principalmente através do crédito rural subsidiado e da Política de Garantia de Preços Mínimos (DIAS; AMARAL, 1999, p. 237). 
Apesar de não ser o momento mais oportuno da política de crédito rural, o principal mercado consumidor da produção da avicultura de postura do território de Santa Maria de Jetibá estava em franca expansão. Entre as décadas de 1970 e 1980 ocorreram importantes transformações estruturais no Espírito Santo que desencadearam intensos movimentos migratórios.

Nesse período ocorreu a modernização da agricultura e a industrialização da Grande Vitória via "grandes projetos". Se na primeira transformação a população era expulsa do campo, na segunda era atraída para as cidades. Dessa forma, o estado se urbanizou (tabela 6) e a população da Grande Vitória quase dobrou em função dos principais fluxos migratórios do estado terem se direcionado para essa região (tabela 12). Isso significa que ocorreu uma importante expansão de mercado consumidor.

Paralelo a essas transformações a produção de ovos do território de Santa Maria de Jetibá foi ampliada em mais de seis vezes, elevando consideravelmente a demanda pelas matérias-primas usadas na fabricação da ração. É a partir desse momento que os maiores avicultores dão início ao estabelecimento de contratos de compra dos principais insumos da ração diretamente do produtor, intermediado por corretores.

Em relação ao aumento da produção de ovos e também da demanda pelos insumos usados nessa produção, duas considerações são necessárias. Primeiramente, a produção implica em consumo e consumo em produção, pois para produzir ovos é necessário a utilização de matérias-primas e de meios de produção, os quais ao serem consumidos pela avicultura de postura resultam em um produto: o ovo. Assim,

\footnotetext{
Produzir é consumir os meios de produção utilizados e gastos, parte dos quais [...] dissolve-se de novo nos elementos universais. Também se consome a matéria-prima, a qual não conserva sua figura e constituição naturais, esta ao contrário é consumida. O próprio ato de produção é, pois, em todos os seus momentos, ato de consumo. [...] A produção, enquanto é imediatamente idêntica ao consumo, o consumo, enquanto coincide imediatamente com a produção, chamam de consumo produtivo (MARX, 1978, p. 108-109).
}

Até se chegar à produção do ovo, a avicultura consome produtos, meios de produção e matérias-primas, tais como: pintainhas, medicações, energia, ração, 
infraestrutura, máquinas e equipamentos, entre outros. No entanto, a ração que tem o maior peso no custo de produção do ovo, é um produto de consumo imediato pela avicultura de postura, diferindo-se, portanto, das máquinas e até mesmo da galinha de postura, os quais são consumidos lentamente pela atividade.

Mas a ração, esse produto de maior peso no custo da produção do ovo e de consumo imediato pela avicultura de postura, demanda matérias-primas produzidas em regiões distantes a mais de $1000 \mathrm{~km}$ de Santa Maria de Jetibá, elevando as despesas com o transporte. Como consequência os custos da produção da avicultura de postura em Santa Maria de Jetibá são maiores em relação a outros estados que estão mais próximos da produção de tais matérias-primas ou até mesmo as produzem.

Em segundo lugar, embora as longas distâncias percorridas para o transporte (circulação) das matérias-primas elevem os custos de produção da ração e, por conseguinte, da avicultura de postura, esses custos são considerados como falsos custos de produção, pois o transporte não participa diretamente do processo produtivo (MARX, 2011). Dessa forma,

Na medida em que a circulação do capital (o produto etc.) não expressa somente as fases necessárias para recomeçar o processo de produção, tal circulação [...] não constitui um momento da produção em sua totalidade por isso, não é circulação posta pela produção, e, na medida em que tem custos, estes são faux frais de production. Os custos de circulação propriamente ditos, i.e., os custos de produção da circulação, na medida em que dizem respeito aos momentos puramente econômicos, à circulação real (levar o produto ao mercado lhe confere novo valor de uso), têm de ser considerados como deduções do mais-valor, i.e., como aumento do trabalho necessário em relação ao trabalho excedente (MARX, 2011, p.732-733).

Mas tal falso custo é mais elevado na avicultura de postura de Santa Maria de Jetibá e somente deduzi-lo da mais-valia não equipara seus custos de produção com outras regiões produtoras, as quais têm custos produtivos bem menores. Para reduzir esse falso custo e colocar no mercado um produto com preços competitivos, os avicultores de porte maior deram início à estruturação de uma cadeia produtiva verticalizada, na qual dominam vários elos, tanto a montante quanto a jusante, pois

$\mathrm{Na}$ avicultura de postura não há um setor industrial que subordine a atividade criatória, pois o ovo é consumido predominantemente in natura e a integração vertical da ração foi feita pelos próprios criadores, inclusive pelos pequenos, uma vez que existe equipamento industrial de pequeno porte disponível no mercado de bens de capital. Portanto, nessa cadeia o 
criador administra suas atividades e toma as decisões de ampliação ou redução da produção, não havendo nenhum agente que desempenhe o papel que os frigoríficos desempenham na avicultura de corte, predominantemente integrada através de contratos de fornecimento (MARTINS, 1996, p. 14).

Embora a avicultura de postura se diferencie da produção para corte em relação à subordinação à um setor industrial específico, algumas particularidades são verificadas em Santa Maria de Jetibá. A verticalização da atividade não se estende aos pequenos avicultores, que se dedicam somente a produção de ovos, embora não sejam produtores integrados a uma agroindústria. Por outro lado, a cadeia produtiva da avicultura de porte grande é intensamente verticalizada, conforme a análise de segue.

A montante, o domínio está relacionado às operações de compra das duas principais matérias-primas da ração e a forma de transportá-las. Primeiramente, o resultado das viagens primeiro ao Centro-Oeste e depois ao Triângulo Mineiro, regiões com produção de milho e soja, culminou no estabelecimento de contratos de compra e venda entre avicultores e produtores de tais matérias-primas, intermediados por corretores especializados. Salienta-se quando esses avicultores iniciaram tais compras, já não dependiam mais da cooperativa.

Para se obter matérias-primas com preços menores, os avicultores de porte grande buscam estabelecer parcerias entre eles, negociando e comprando coletivamente tais insumos, mas os pagamentos são realizados individualmente. Também buscam fazer tais negociações no meio da safra quando os preços tendem a ser menores e fazem estoques dessas matérias-primas.

Trata-se de uma forma de cooperação competitiva, até porque à medida em que a atividade foi se expandindo, os avicultores passaram a negociar grandes volumes de matérias-primas. Em 2014 a avicultura de postura consumiu mensalmente 28.672 toneladas de milho e 13.141 toneladas de farelo soja (AVES, 2015). Grande parte dessas matérias-primas são consumidas pelos avicultores de porte grande.

Recentemente os avicultores realizaram operações de hedge cambial para a compra das principais matérias-primas da ração, com o intuito de se protegerem das flutuações cambiais do dólar, uma vez que tais insumos são commodities. 
Considerando que desde que o sistema de paridade do dólar atrelada ao ouro de Bretton Woods foi substituído pelo sistema de taxas de câmbio flutuantes na década de 1970, as oscilações de preços das commodities foram intensificadas.

O termo hedge significa proteção e quando se opta por esse tipo de operação o que se objetiva é se resguardar dos riscos das oscilações de preços, por isso se estabelece um preço fixo de uma mercadoria em mercados futuros. No caso concreto que está em análise, as operações de hedge cambial foram realizadas entre os avicultores e a Cargill. Para os avicultores foi realizada uma compra futura de matéria-prima e definido um preço fixo a ser pago, independente das variações cambiais. O mesmo vale para a multinacional, que realizou uma venda futura a preços fixos. Trata-se, portanto, de uma operação que reduz riscos.

Considerando as elevadas oscilações do câmbio, em alguns momentos a avicultura de postura pode ter prejuízos, mas também em outros, lucros bem mais elevados. Apesar das operações de hedge cambial reduzirem tais riscos e permitirem maior controle da previsão de lucro, as estratégias organizativas dos avicultores para a aquisição das matérias-primas da ração têm possibilitado maior capacidade de negociação dos preços. Em momento de preços oportunos de preços das matérias-primas, se for vantajoso os avicultores até recorrem ao crédito rural para realizarem compras em volumes maiores.

Ainda a montante da cadeia produtiva, desde que iniciaram a compra das matérias-primas da ração década de 1980, a forma de transportá-las sempre foi dominada pelos avicultores de porte maior. Nessa época as diferenças em relação ao tamanho dos plantéis de aves eram muito menores que as atuais e os grandes avicultores eram aqueles com plantéis acima de 20 mil, conforme mencionado anteriormente.

Eram exatamente avicultores com esse porte que negociavam coletivamente preços de matérias-primas e as transportavam em caminhões próprios. Não havia e nem há uma empresa terceirizada transportando tais insumos. Os caminhões que transportam o milho e o farelo de soja são usados exclusivamente para esse fim e normalmente partem vazios e voltam carregados de matérias-primas. Apesar disso, é mais vantajoso para a avicultura de postura transportar as matérias-primas do que terceirizar o serviço. 
À medida que a avicultura foi se expandindo, a frota de caminhões dos avicultores de porte grande foi sendo ampliada, pois é usada no transporte das matérias-primas, dos ovos e do esterco. Em 2014 a frota de caminhões de Santa Maria de Jetibá era a 8ª maior do estado, com 2.413 unidades (DENATRAN, 2015), grande parte usada pela avicultura de postura. Toda a manutenção e conserto dos caminhões é realizada em oficinas mecânicas de propriedade dos avicultores de porte grande.

Também a montante, a produção das pintainhas não é realizada pelos avicultores, pois trata-se de uma atividade complexa e a aquisição das pintainhas ocorre somente a cada renovação de lote de aves, portanto não seria vantajoso produzi-las. Por opção, esse elo da cadeia produtiva não é dominado pelos avicultores. São usadas predominantemente linhagens da Hy-Line, empresa localizada em São Paulo que produz, debica e transporta as pintainhas com um dia de vida.

Por sua vez, o domínio a jusante da cadeia produtiva refere-se à forma de comercializar e transportar o ovo, que é similar a aquisição das matérias-primas. Todo o procedimento de comercialização e transporte dos ovos sempre foi realizado pelos avicultores de porte maior, os quais também são proprietários dos caminhões usados nessa etapa da atividade. O transporte dos ovos é feito por caminhões de carrocerias tipo baú e, portanto, são diferentes dos usados para as matérias-primas.

Os avicultores de porte maior sempre realizaram vendas diretas para os canais de comercialização existente em cada momento, embora nos anos 1960 e 1970 o mercado de hortigranjeiros fosse bastante desorganizado, tanto no Espírito Santo quanto no país. Nessa época, aumentou consideravelmente a demanda por alimentos em decorrência da expansão do mercado consumidor urbano, pois

\footnotetext{
- país adentrava nos processos de urbanização e industrialização, determinando a formação de mercado interno para alimentos, bem como a pressão da demanda urbana por hortigranjeiros. Dado esse contexto, a preocupação do governo federal consistia em abrandar o custo de vida especialmente o custo de reprodução da força de trabalho via poder de compra dos salários (WEGNER, 2011, p.74).
}

Dessa forma, organizar o mercado de hortigranjeiros era uma alternativa para assegurar a oferta e reduzir parte do custo de reprodução do trabalhador, tanto que 
na década de 1960 foi iniciada a construção das Centrais de Abastecimento CEASA, em algumas unidades da federação. No Espírito Santa a CEASA foi inaugurada somente em 1977, uma vez que o processo de industrialização e urbanização ocorreu um pouco mais tarde, entre 1970 e 1980.

Nesse contexto, os avicultores de porte grande acompanharam a evolução da estrutura de comercialização. Primeiramente estabeleceram relações comerciais com o Mercado da Vila Rubim em Vitória e também com supermercados da Grande Vitória, inaugurados a partir da década de 1960. Depois com a CEASA, localizada no município de Cariacica, na Grande Vitória. Nas décadas subsequentes, à medida que a produção de ovos se expande, sobretudo a partir dos anos 1990, são estruturados novos canais de comercialização e, então, os avicultores de porte grande passam a comercializar diretamente com grandes atacadista e redes de supermercados.

Diferentemente, os pequenos avicultores sempre foram dependentes de comerciantes intermediários para venderem a produção. A partir de 2002 a cooperativa passou a comprar a produção dos avicultores associados, mas nem sempre os preços praticados pela Coopeavi são mais atrativos.

Até a década de 1990, quase toda a produção de ovos de Santa Maria de Jetibá era consumida no âmbito estadual. Praticamente não havia uma produção excedente para ser consumida por outros estados. Nos anos 1960 e 1970, quando a atividade ainda estava se estruturando, o principal mercado consumidor estava localizado na Grande Vitória, o maior aglomerado urbano do estado. No entanto, a urbanização e a industrialização do Espírito Santo ocorrida nos anos 1980, ampliou e estendeu o mercado consumidor para todo o estado.

Nos anos 1990, no âmbito da política neo-liberal, consolida-se a abertura econômica do país, pois "a redução tarifária, com quase cinco anos de sobrevalorização da taxa de câmbio, produziu intensa abertura às importações" (BRANDÃO, 2007, p.159). Sem desconsiderar as críticas tecidas ao modelo neoliberal e suas consequências socioeconômicas negativas, para a avicultura de postura de Santa Maria de Jetibá, a abertura econômica vai permitir a importação máquinas e equipamentos para a automação das granjas. 
Inicia-se, então, a partir de 1998, a reestruturação produtiva da avicultura de postura por meio o processo de automação das granjas de porte grande, plenamente assentada em tecnologias importadas. Conforme pode ser observado na Figura 15, partir desse momente a atividade passa a crescer em ritmo muito acelerado e, desde 2000 , excluindo o ano de 2002, o município tornou-se o segundo maior produtor de ovos do país (IBGE, 1989/2014).

Figura 15 - Santa Maria de Jetibá: evolução da produção de ovos - 1989 a 2014 (mil dúzias)

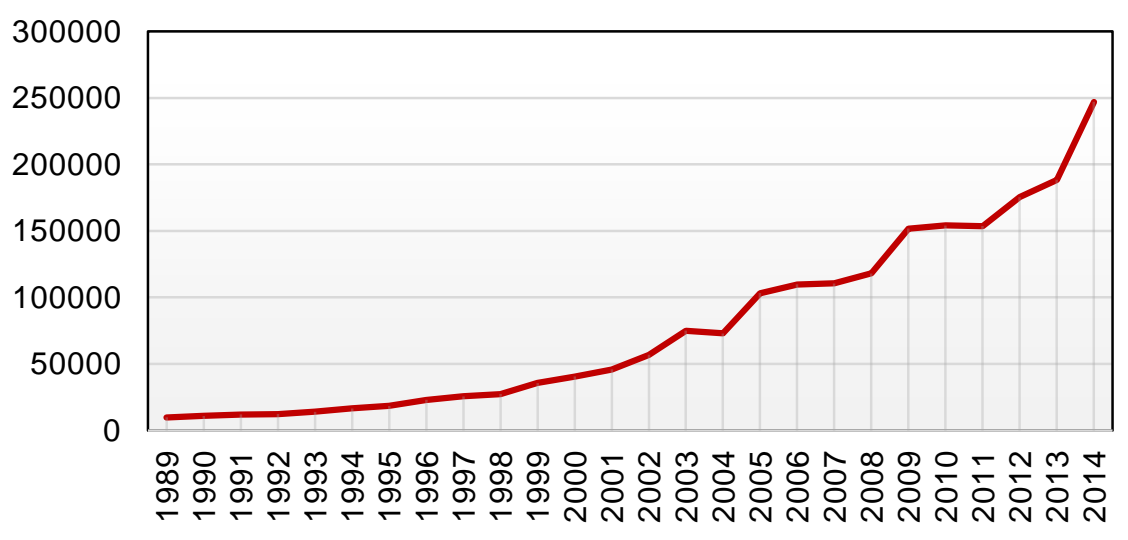

Fonte: IBGE/Pesquisa Pecuária Municipal, 1989 a 2014.

Elaboração: Bergamin, M. C.

Antes de iniciar a automação, a produção de ovos era ampliada em 1.762.000 dúzias a cada ano, mas após, esse crescimento passou a ser 12.917 .000 dúzias. Em 1997, último ano da produção totalmente manual, a avicultura produzia 25.670.000 dúzias, mas em 2014, quando grande parte da atividade já se encontrava automatizada, a produção passou para 246.994 .000 dúzias, ou seja, quase dez vezes maior (IBGE/PPM, 1989 a 2014).

Há várias décadas o município paulista de Bastos é o maior produto de ovos do país e mesmo quando Santa Maria passou a ocupar a segunda posição, havia uma diferença muito grande entre ambos. O município paulista produzia quase três vezes mais que o capixaba. No entanto, há alguns anos a produção de ovos em Santa Maria de Jetibá vem apresentando a maior taxa de crescimento do país e, dessa forma, a diferença entre os dois municípios foi sendo reduzida. Em 2014 a produção de Santa Maria de Jetibá foi de 246.994.000 de dúzias e a de Bastos foi de 260.446.000 de dúzias (IBGE/PAM, 2014). Mantido esse ritmo de crescimento, a produção de Santa Maria de Jetibá ultrapassará a de Bastos em muito pouco tempo. 
Automatizar a produção foi uma opção certeira, face aos custos de produção mais elevados da avicultura de postura em Santa Maria de Jetibá. Nesse contexto, o nível de automação da atividade no município é o maior do país e superior a $65 \%$, enquanto a média para as principais regiões produtoras do país é de $45 \%$ a $50 \%$ (AVES, 2015). Em 2014 o governo federal lançou uma linha de crédito denominada Incentivo à Inovação Tecnológica na Produção Agropecuária - Inovagro, que financia até 1 milhão de reais para a incorporação inovações técnicas, entre elas a automação.

Apesar do elevado volume de investimento requerido pela automação, uma vez que o custo médio por ave é de aproximadamente de $R \$ 35,00$, essa inovação mecânica potencializa as demais, reduz tanto a perda dos insumos quanto dos ovos, reduz significativamente a demanda por mão de obra, melhora a qualidade do ovo, entre outros. Sem desconsiderar as demais inovações, a automação elevou intensamente a produtividade do trabalho, o que representa para o capital maior capacidade de acumulação.

Decorrente do crescimento da atividade, a produção de ovos de Santa Maria de Jetibá passou a ser bem superior à demanda estadual e a comercialização desse produto se estendeu para outras unidades da federação. Segundo estimativa da secretaria municipal da agricultura, $42 \%$ da produção é consumida no âmbito estadual, $40 \%$ segue para o mercado do Rio de Janeiro e $18 \%$ para a Bahia.

Se por um lado Santa Maria está distante das regiões produtoras das matérias-primas da ração, por outro lado está próxima de grandes centros consumidores, o que facilita o escoamento da produção de ovos e reduz os custos com o transporte.

O produto da avicultura de corte passa por um processamento industrial de alguma agroindústria do setor e por isso tem marca (Perdigão, Sadia, Seara, etc.). Já o produto da avicultura de postura não tem marca e, então, para conquistar o mercado o ovo tem que apresentar algumas características, como ausência de contaminação, frescor, pois tem validade curta e a casca tem que ser limpa e íntegra. Esses atributos são mais fáceis de serem assegurados por uma produção automatizada em grande escala, conforme a de Santa Maria de Jetibá. Embora não tenha marca, o ovo tem procedência e a sua qualidade pode ser identificada pelo produtor. 
Por sua vez, embora o esterco não seja um produto, mas um subproduto da avicultura de postura, a destinação desse resíduo nunca foi um problema para a atividade. Pelo contrário, sempre houve demanda por esse subproduto da avicultura, que na verdade acaba se metamorfoseando em produto. Avicultura de postura e horticultura surgem ao mesmo tempo em Santa Maria de Jetibá e, por produzir esterco, a primeira atividade foi fundamental para a expansão da segunda.

No entanto, as granjas automáticas produzem um esterco fresco devido a frequência da sua retirada ocorrer semanalmente, diferente das granjas manuais onde a retirada é anual. Embora para a horticultura o esterco das granjas manuais seja mais adequado, a produção das granjas automáticas é tão elevada que extrapolada a capacidade local de absorver esse produto. A maior parte da produção das granjas automáticas é consumida por outros municípios do estado e todo o comércio e transporte é também realizado pelos avicultores. O esterco pode representar até $10 \%$ do lucro da atividade, dependendo do momento econômico.

Além dos avicultores desenvolverem uma inovação agronômica por meio da estruturação de uma cadeia produtiva extremamente verticalizada e de estarem próximos de grandes mercados consumidores, dois aspectos locais foram favoráveis para a expansão da avicultura de postura. O primeiro é de ordem natural e se refere às condições de temperatura de Santa Maria de Jetibá, que até o momento tem assegurado níveis elevados de produtividade das aves.

O segundo aspecto refere-se à qualidade da mão de obra. Enquanto em Santa Maria de Jetibá um trabalhador cuida de 100 mil aves, nas demais regiões de produção automatizada, geralmente são 50 mil aves para cada trabalhador. Mesmo que a demanda por mão de obra tenha sido significativamente reduzida pela automação e que também represente uma pequena parte dos custos de produção da avicultura de postura, o desempenho do trabalhador assalariado de Santa Maria de Jetibá desperta atenção.

Conforme será analisado no próximo capítulo, na produção agrícola do município há uma extrema valorização do trabalho, mas são agricultores familiares, cujo produto do trabalho lhes pertence. No entanto, nas granjas o trabalho é assalariado e consequentemente $o$ resultado do trabalho não pertence ao trabalhador, mesmo assim os trabalhadores além de valorizarem, são também extremamente comprometidos com o trabalho. 
Tais atributos referem-se aos trabalhadores descendentes de pomeranos, os quais se diferenciam dos demais. Os avicultores reafirmam essas diferenças e declaram a preferência pelos descendentes dos pomeranos, os quais executam suas atividades laborais como se a granja Ihes pertencesse. São trabalhadores que não se limitam simplesmente ao cumprimento de uma jornada de trabalho, mas que executam suas tarefas objetivando o melhor desempenho produtivo das granjas.

Do ponto de vista do capital, representados nesse caso, sobretudo pelos avicultores de porte grande, o trabalhador disciplinado e comprometido amplia as possibilidades de acumulação capitalista e produz mais riqueza. Do ponto de vista do trabalhador, o comprometimento amplia e obscurece a exploração a que são submetidos por meio do trabalho, como via de regra, mal remunerado.

Embora a maior parte da produção de ovos ocorra em bases tecnológicas modernas e assentada em uma cadeia produtiva intensamente verticalizada, dezenas de pequenos avicultores produzem em condições diferentes. Esses avicultores incorporaram bem menos tecnologias e na cadeia produtiva participam somente com a produção de ovos, o que resulta em subordinação tanto a montante, quanto a jusante.

A permanência dos avicultores de pequeno porte, que trabalham em bases familiares de produção, está relacionada com o fato de se submeterem a longas jornadas de trabalho. Aspecto que será abordado no capítulo seguinte.

\subsection{A avicultora de postura como indutora do crescimento econômico de Santa Maria de Jetibá}

É de amplo conhecimento que o processo de modernização da agricultura no Brasil foi conservador porque não inseriu determinadas culturas, regiões e tipos de agricultores (SILVA, 2003). Embora tenha promovido importantes ganhos de produção e produtividade, a modernização foi responsável pelo aumento da concentração da terra, do êxodo rural, da degradação ambiental e das desigualdades no campo.

Sem negligenciar o caráter conservador e destrutivo da modernização, identificamos que em Santa Maria de Jetibá esse processo se manifestou de forma 
um pouco diferente. Diretamente, a terra não é um meio de produção para a avicultura, atividade que quanto mais se moderniza, demanda menos área por ave. Por isso não provocou concentração da terra em Santa Maria de Jetibá.

A avicultura também não entra em conflito com a produção agrícola. Pelo contrário, pois um de seus subprodutos é um insumo fundamental para a produção de hortaliças. Mesmo que os avicultores de porte grande e médio tenham condições produtivas muitos superiores em relação aos de porte pequeno, estes não foram eliminados pela grande produção e nem são residuais. O conflito aparece em outra relação, conforme será abordado no capítulo seguinte.

Embora o produto da avicultura de postura não tenha como destino principal o mercado externo e também seja consumido predominantemente na forma in natura, a atividade foi intensamente modernizada. As barreiras que a natureza impõe ao capital foram praticamente eliminadas na avicultura de postura. A galinha é um animal de crescimento rápido, o que permitiu reduzir o tempo de produção das inovações biológicas, resultando em grandes avanços no melhoramento genético. As linhagens foram tão alteradas que parecem novas espécies. A galinha também é um animal com baixo índice de conversão alimentar, ou seja, pequeno consumo de ração para produzir um ovo, tornando barato o preço desse alimento.

Constituídas por máquinas e equipamentos automáticos, as granjas se assemelham a uma indústria, tanto que nesse padrão tecnológico, a atividade é denominada de produção industrial de ovos. Os avanços tecnológicos conferiram níveis elevados de produtividade do trabalho e transformaram a avicultura de postura em uma atividade atrativa para o capital, tanto que em Santa Maria de Jetibá a produção de ovos é realizada predominantemente por avicultores de porte grande.

Em que pesem tais considerações, a avicultura de postura foi indutora do crescimento econômico de Santa Maria de Jetibá. Considerando que os dados disponíveis se estendem até 2012, desde 2009 o município vem se destacando por apresentar o maior valor adicionado da agropecuária ${ }^{12}$ do Espírito Santo (IJSN, 2009-2012). Na composição do valor adicionado da agropecuária, a pecuária

\footnotetext{
$12 \mathrm{O}$ valor adicionado da agropecuária é usado para calcular o PIB e se baseia nos seguintes dados levantados pelo IBGE: Produção Agrícola Municipal, Produção da Extração Vegetal e da Silvicultura e Pesquisa Pecuária Municipal. Apesar de não serem os melhores dados, são os disponíveis e os que as instituições públicas utilizam para calcular o PIB. Mesmo não sendo tão precisos, esses dados servem como parâmetro para se identificar a participação das atividades do setor agropecuário.
} 
representa $83,03 \%$, a produção agrícola $16,72 \%$ e o extrativismo vegetal e a silvicultura $0,25 \%$. Considerando somente a produção da pecuária, a avicultura de postura representa quase 100\% (IBGE, 2013).

Tanto a avicultura de postura, quanto a produção de hortaliças com fins comerciais, são atividades que surgiram quase na mesma época. Desde quando se iniciou, a avicultura de postura foi fornecedora de esterco para a produção de hortaliças. Como a avicultura foi crescendo lentamente, no início a produção de esterco não era suficiente para atender a demanda da produção de hortaliças, então, os agricultores buscavam esse insumo no município de Domingos Martins. À medida que a atividade foi se expandindo, a produção de estercou passou a ser suficiente e, após algumas décadas, tornou-se bem maior que a capacidade de absorção da horticultura.

Conforme poder ser observado na Figura 16, a avicultura de postura ocupa a posição central no crescimento econômico de Santa Maria de Jetibá, contribuindo para o desenvolvimento de várias atividades. O fornecimento local do esterco de galinha foi fundamental para a expansão da horticultura, pois até o presente é um excelente adubo para o cultivo de hortaliças, tem menor custo e contribui para a conservação do solo.

A produção de hortaliças vai se expandindo e passa a demandar cada vez mais, maior quantidade maior de insumos, máquinas e equipamentos, os quais são adquiridos predominantemente no comércio local. Estimula-se, então, a abertura e a expansão de estabelecimentos comerciais especializados em produtos agropecuários. Como as hortaliças são culturas de ciclo curto e a maioria colhida e vendida semanalmente, os agricultores usam com muita frequência tanto os serviços bancários para troca de cheques, depósitos e saques, quanto o comércio local para aquisição de insumos para a produção.

Embora na composição do valor adicionado da produção agropecuária, a produção de hortaliças tenha uma participação muito menor que a avicultura de postura, mas é a atividade que mais gera empregos, o que the confere extrema importância. Dada as condições técnicas da horticultura, grande parte do trabalho é manual e, dessa forma, a atividade demanda muita mão de obra, predominantemente familiar. 


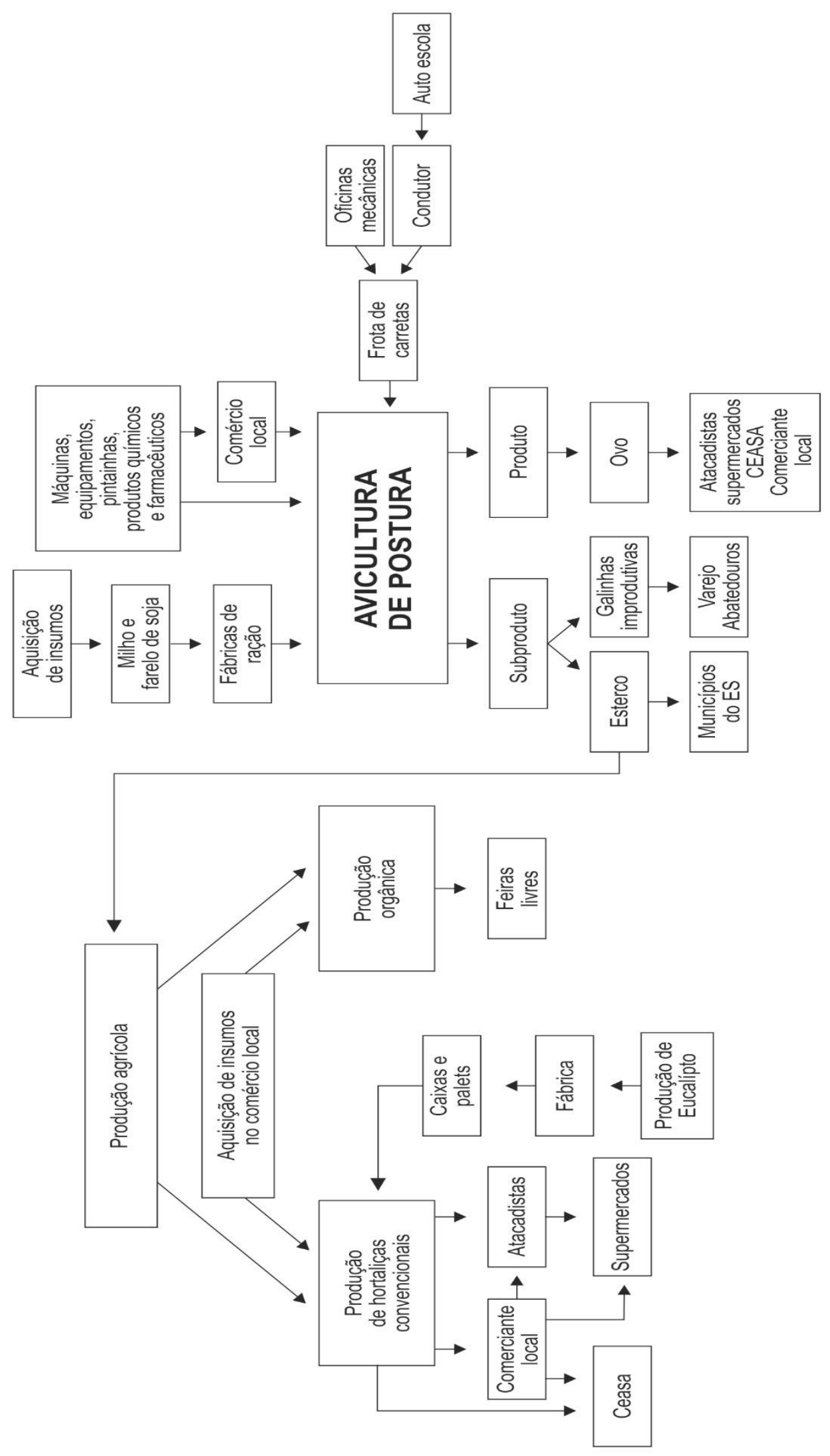

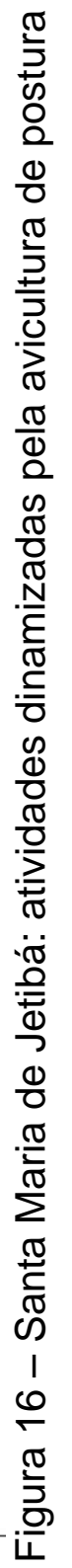


A produção de hortaliças também demanda a utilização de caixas de madeira para o acondicionamento da produção e pallets para unitizar (agrupar volumes) as cargas de hortaliças. São produtos não retornáveis e produzidos com madeira de reflorestamento, o eucalipto. Segundo estimativa da Secretaria Municipal de Agropecuária, existem aproximadamente 50 fábricas produtoras de caixas e pallets, localizadas na zona rural (KRUGER, 2014).

Decorrente da utilização do eucalipto como matéria prima para a fabricação das caixas e pallets, houve expansão da cultura, cuja produção praticamente não é destinada à fabricação de celulose. São pequenos cultivos localizados em áreas das propriedades que anteriormente eram ocupadas por pastagens e geralmente não são adequadas para a produção de hortaliças.

Contraditoriamente, com a modernização da agricultura em Santa Maria de Jetibá, não houve redução da área ocupada por matas, mas ampliação. Isso ocorreu porque com a expansão da horticultura no município, a nova atividade passou a demandar menos área que a cafeicultura. Em relação àquelas áreas anteriormente ocupadas com café e pastagem, uma boa parte foi abandonada, regenerou-se e voltou a ser mata, ou foi transformada em cultivo de eucalipto. Dessa forma,

o município possuía $106,81 \mathrm{~km}^{2}$ de mata em estágio médio a avançado e $41,42 \mathrm{~km}^{2}$ de mata em estágio inicial no ano de 1970, ocupando cerca de 20,13\% do território. Esses números em 2005 passaram para 254,306 km² de mata em estágio médio a avançado e $19,344 \mathrm{~km}^{2}$ de mata em estágio inicial, totalizando cerca de $37,17 \%$ de ocupação do município (ALMEIDA JÚNIOR, 2006, p. 50)

Isso não significa que não tenha havido impactos ambientais decorrentes da modernização. Pelo contrário, o consumo intensivo de agrotóxicos contamina o ambiente e agricultores, bem como, o uso frequente de irrigação compacta e saliniza os solos.

Por sua vez, embora a produção orgânica tenho surgido como reação aos danos causados à saúde dos agricultores familiares, a atividade também utiliza o esterco de galinha para fazer a compostagem, que será transformada em adubo orgânico, um insumo de grande importância para a atividade.

Indiretamente a avicultura de postura requer a prestação de uma série de serviços e por isso surgiram ou expandiram algumas atividades no município, tais 
como: a) hospedagem - ampliação do número de leitos e construção de um novo hotel com 92 apartamentos, para atender principalmente representantes de empresas ou prestadores de serviços que atendem a avicultura de postura, sobretudo as granjas de porte grande; b) autoescola - formação de condutores de caminhões para atuarem no transporte das matérias-primas da ração e da produção de ovos; oficinas mecânicas - manutenção da frota de caminhões usada pela avicultura, entre outras.

Diretamente, para atender a avicultura de postura foram construídas fábricas de ração. O município dispõe de três fábricas com autorização para comercializarem a produção e registradas no Ministério da Agricultura, Pecuária e Abastecimento MAPA. Para atender exclusivamente a própria granja, existem aproximadamente 30 fábricas de ração, que oscilam de pequeno à grande porte (KRUGER, 2014). Acrescente-se também que as fábricas de ração demandam serviços de transporte das matérias-primas que utilizam.

Apesar de ser indutora, direta e indiretamente, de diversas atividades econômicas e ter a maior contribuição no valor adicionado bruto da agricultura, a avicultura de postura não é uma importante geradora de empregos. Pelo nível tecnológico da avicultura, sua capacidade de absorver mão de obra é significativamente inferior à da produção agrícola, predominantemente assentada no trabalho familiar. Enquanto a primeira gera receitas, a segunda gera empregos. 


\section{A PRODUÇÃo AGRÍCOLA DE SANTA MARIA DE JETIBÁ E SUAS DETERMINAÇÕES: UMA GRANDE PRODUÇÃO DE HORTALIÇAS ASSENTADA NO TRABALHO FAMILIAR E NA PEQUENA PROPRIEDADE, MAS INTENSAMENTE SUBORDINADA AO COMÉRCIO}

\subsection{Introdução e expansão da horticultura comercial em Santa Maria de Jetibá}

Nas décadas de 1930 e 1940 já haviam cultivos comerciais de batata inglesa ${ }^{13}$ no território de Santa Maria de Jetibá, concentrados principalmente na localidade de Recreio, cuja produção era transportada em mulas até a sede de Santa Leopoldina, de onde seguiam em canoas ou caminhões até a região da capital do Estado (SCHWARZ, 1993).

Nessa fase inicial da atividade, um dos fatores que contribuiu para a introdução da horticultura comercial foi a fundação da estação de fruticultura. Fundada em 1935 pelo governo estadual em Santa Maria de Jetibá, a estação distribuiu sementes de hortaliças e mudas de árvores frutíferas (SCHWARZ, 1993). A fruticultura não se desenvolveu, mas os cultivos de hortaliças se expandem após algumas décadas.

Nessa época as condições para o transporte rodoviário eram muito precárias. A construção da estrada ligando a sede de Santa Maria de Jetibá à Santa Leopoldina, sem pavimentação, ocorreu somente em 1949 decorrente da construção da hidrelétrica de Rio Bonito (SCHWARZ, 1993). As estradas no interior de Santa Maria de Jetibá eram raras e precárias, o que inviabilizava o transporte de hortaliças mais perecíveis. Somente aquelas mais resistentes, como a batata por exemplo, suportavam as condições e o tempo de transporte, uma vez que "imagine-se o que ocorreria com tomates transportados em dorso de mulas de Santa Maria a Santa Leopoldina, depois a Vitória em caminhão" (ROCHE, 1968, p. 95)

Em 1960 a cafeicultura ainda era mais importante economicamente, mas várias hortaliças já eram cultivadas em Santa Maria de Jetibá e por ordem decrescente, as mais importantes eram: tomate, cebola, couve, couve-flor, pimentão,

\footnotetext{
${ }^{13}$ Embora a Classificação Nacional de Atividades Econômicas - CNAE, na qual se baseia o Censo Agropecuário, não considere o cultivo da batata inglesa como atividade da horticultura, para a Embrapa e vários órgão estaduais de pesquisa agropecuária, esse tubérculo é uma hortaliça.
} 
cenoura e alho (ROCHE, 1968). A horticultura passou a ser cultivada em áreas até então inapropriadas para as culturas existentes.

As várzeas ou brejos localizados nos fundos dos vales, até então áreas inutilizadas pelos agricultores, passaram a ser cultivados com hortaliças. "Tais brejos, abandonados no começo, pelos colonos, reduzindo-lhes o valor das propriedades, constituem hoje o essencial de seus patrimônios" (ROCHE, 1968, p. 94).

Embora a modernização da agricultura tenha se iniciado no Espírito Santo somente nos anos 1970, Roche (1968) constatou que em 1961 Santa Maria de Jetibá já incorporava algumas inovações técnicas nos cultivos de hortaliças. Como não havia energia elétrica, sistemas de irrigação eram empregados nas propriedades nas quais as condições naturais permitiam irrigar por gravidade ou por infiltração. Alguns agricultores também chegaram a irrigar manualmente com mangueiras, mas a atividade demandava muito trabalho.

Além dos sistemas de irrigação, os agricultores também usavam inovações físico-químicas, como fertilizantes e defensivos (ROCHE, 1968). No entanto, todas as inovações mencionadas estavam em processo inicial de incorporação, limitandose ainda a poucos agricultores. Das inovações, os fertilizantes orgânicos foram os primeiros a serem incorporados por um número maior de agricultores, pois eram produzidos localmente pela avicultura de postura.

Na década de 1980, o território de Santa Maria de Jetibá havia ampliado consideravelmente a incorporação de insumos da modernização da agricultura e já era o maior produtor de hortaliças do Espírito Santo. Dos hortifrutigranjeiros comercializados na CEASA estadual, 31\% eram provenientes de Santa Leopoldina (IJSN, 1980), mas essa produção estava concentrada principalmente no território de Santa Maria de Jetibá.

Algumas condicionantes locais, como as condições naturais, a produção e a oferta de adubo orgânico local, a melhoria das estradas e a acentuada valorização do trabalho pelos descendentes pomeranos, contribuem diretamente para explicar a expansão da horticultura em Santa Maria de Jetibá. Aliada a essas condicionantes, mudanças estruturais do Espírito Santo promoveram o crescimento vertiginoso da 
população da Grande Vitória, principal centro consumidor dos hortifrutigranjeiros produzidos por Santa Maria de Jetibá.

O município caracteriza-se por ter uma produção agrícola bastante diferenciada em relação ao contexto espacial capixaba, que é marcado pelo predomínio das culturas permanentes e destinadas ao mercado externo, com destaque para a cafeicultura. Mesmo inserido nesse contexto espacial, Santa Maria de Jetibá segue o caminho inverso, conforme pode ser observado na Figura 17, uma vez que no município a horticultura é predominante e a produção agrícola é destinada prioritariamente para o mercado interno.

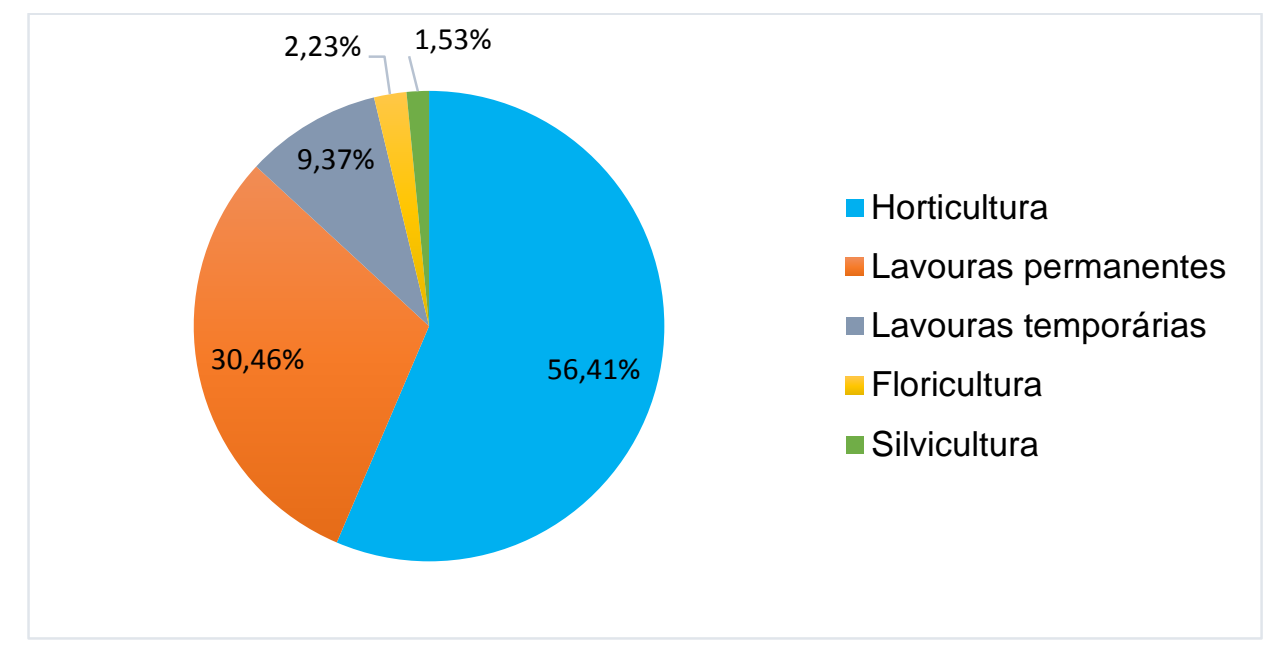

Figura 17 - Santa Maria de Jetibá: Participação das atividades agrícolas por valor bruto da produção (2006).

Fonte: IBGE/Censo Agropecuário, 2006.

Grande parte dos cultivos de hortaliças caracteriza-se por apresentar processos biológicos de curta duração, em geral de 3 a 6 meses, e com produtos de rápida perecibilidade. Os cultivos de hortaliças são realizados de forma intensiva, em pequenas propriedades e demandam a execução sistemática de um grande número de serviços.

Esses aspectos não são meros detalhes, mas têm implicações na incorporação de progresso técnico, na organização do trabalho e na subordinação ao comércio. Como a frequência das colheitas é semanal (em algumas culturas até duas ou três vezes por semana) e a produção das propriedades diversificada, as oscilações no tempo de trabalho, analisadas no conjunto da propriedade, são insignificantes. Ao longo de um dia de trabalho a família planta, colhe, pulveriza, irriga 
e aduba. As diferentes etapas do ciclo produtivo são realizadas ao longo de uma única jornada de trabalho.

\subsection{Relações de trabalho na produção agrícola: o predomínio da mão de obra familiar e a supervalorização do trabalho}

Em Santa Maria de Jetibá no processo de trabalho da produção agrícola a mão de obra familiar é determinante. Ao longo do ano raramente se recorre ao trabalho contratado, nem de forma temporária e muito menos permanente. Nas poucas propriedades cuja produção é bem maior que a força de trabalho da família, são estabelecidos contratos de parceria nos quais o trabalho também é familiar e, portanto, a relação não é mediada pelo salário. $O$ trabalho assalariado é usado somente de forma pontual.

Segundo o Censo Agropecuário (2006), 87,63\% do pessoal ocupado na produção agrícola ${ }^{14}$ de Santa Maria de Jetibá têm laço de parentesco com o produtor, ou seja, são agricultores que trabalham com a família. Nesse percentual não estão incluídos os parceiros e os arrendatários, porque nessa relação os trabalhadores não têm vínculos de parentesco com o proprietário da terra. No entanto, no caso de Santa Maria de Jetibá, ambas as relações de trabalho empregam a mão de obra familiar e os trabalhadores, por não terem a propriedade privada da terra, pagam uma renda para a usarem, seja em dinheiro seja em produto. Dessa forma, nas atividades agrícolas do município a agricultura familiar é a relação de produção predominante e quase absoluta.

Diferentemente de uma relação capitalista de produção, na qual capital e trabalho são separados e estão em posições antagônicas, a agricultura familiar é uma relação de produção não capitalista, na qual a família ao mesmo tempo em que é proprietária dos meios de produção, assume o trabalho e a gestão da propriedade rural. "A agricultura familiar é aquela em que a gestão, a propriedade e a maior parte do trabalho vêm de indivíduos que mantêm entre si laços de sangue ou de casamento" (ABRAMOVAY, 1998, p. 146).

\footnotetext{
${ }^{14}$ Foram consideradas como produção agrícola as seguintes atividades: culturas temporárias e permanentes, horticultura e floricultura e produção de florestas plantadas.
} 
Trata-se, portanto, de uma relação de produção que não é mediada pela categoria salário por combinar simultaneamente propriedade dos meios de produção e trabalho produtivo. Consequentemente no processo de trabalho da agricultura familiar não há extração de mais-valia, embora o capital encontre outras formas de subjugá-la.

Verifica-se que o processo de trabalho da agricultura familiar não separa o trabalhador das condições objetivas de produção e, dessa forma, o resultado da produção "constitui um rendimento indivisível, do qual é impossível separar o que foi gerado pelo trabalho, pelo investimento do capital ou como renda da terra" (WANDERLEY, 1998, p. 32).

Apesar de ser uma relação não capitalista de produção e de não haver geração de mais-valia, a agricultura familiar está inserida no processo global de reprodução do capital e, no caso da de Santa Maria de Jetibá, essa forma social de produção está subordinada ao capital. A subordinação ocorre porque o produto do trabalho está diretamente subordinado ao capital, haja vista o domínio exercido pelo comércio em relação à agricultura familiar. A aparente autonomia do trabalho da família em decidir quanto e quando trabalhar e o quê produzir, acaba sendo influenciada por fatores externos à propriedade e, dessa forma, o trabalho da família torna-se indiretamente subordinado ao capital.

Por sua vez, embora a mão de obra seja essencialmente familiar, o número de membros que as famílias dispõem para realizar o trabalho agrícola na propriedade é reduzido. Constatou-se no trabalho de campo que as famílias contam em média com a força de trabalho de três pessoas adultas. Isso decorre tanto da perda dos filhos que se casam quanto da queda da taxa de fecundidade.

Os casamentos geralmente ocorrem pouco depois dos 20 anos de idade e com isso os pais perdem a mão de obra dos filhos em uma fase em que são bem jovens e plenamente produtivos para o trabalho. Relativo à taxa de fecundidade total ${ }^{15}$, o indicador do município é de 1,62 filhos por mulher, um dos menores do Espírito Santo e bem abaixo da média estadual que é de 1,80 (Atlas do Desenvolvimento Humano, 2013). Dessa forma, tanto entre os casais de agricultores

\footnotetext{
${ }^{15}$ Número médio de filhos que uma mulher deverá ter ao terminar o período produtivo ( 15 a 49 anos de idade).
} 
familiares mais jovens quanto entre os mais velhos, a força de trabalho é constituída por poucos membros.

Ainda sobre a fecundidade, o indicador do município torna-se relevante quando se considera que as taxas de fecundidade são mais elevadas na zona rural. No entanto, mesmo que o percentual de população rural do município seja quatro vezes maior que os percentuais estaduais e nacionais, conforme pode ser observado na tabela 18, a taxa de fecundidade total de Santa Maria de Jetibá é baixa.

Tabela 18

População Rural e Urbana, 2010

\begin{tabular}{c|c|c|c|c|c}
\hline Espacialidade & Urbana & $\%$ & Rural & $\%$ & Total \\
\hline Brasil & 160.925 .804 & 84,36 & 29.829 .995 & 15,64 & 190.755 .799 \\
Espírito Santo & 2.931 .472 & 83,40 & 583.480 & 16,60 & 3.514 .952 \\
Santa Maria de Jetibá & 11.797 & 34,32 & 22.379 & 65,48 & 34.176 \\
\hline
\end{tabular}

Fonte: IBGE/Censo Demográfico, 2010.

Acrescente-se também que o nível de instrução, sobretudo da mulher, é conhecidamente um fator fundamental para a queda de fecundidade. No entanto, em Santa Maria de Jetibá o nível de escolarização é muito abaixo das médias estadual e nacional e um dos menores do Espírito Santo, conforme pode ser observado na tabela 19. Observa-se que mesmo entre a população mais jovem, entre 18 e 24, somente $1 / 3$ concluiu o ensino médio.

Tabela 19

Santa Maria de Jetibá: indicadores de escolaridade- 2010

\begin{tabular}{l|c|c|c}
\hline Espacialidade & $\begin{array}{c}\% \text { de 18 anos ou mais } \\
\text { com ensino } \\
\text { fundamental completo }\end{array}$ & $\begin{array}{c}\text { \% de 18 anos ou } \\
\text { mais com ensino } \\
\text { médio completo }\end{array}$ & $\begin{array}{c}\% \text { de 18 a 24 anos } \\
\text { com médio } \\
\text { completo }\end{array}$ \\
\hline Brasil & 54,92 & 37,89 & 47,47 \\
Espírito Santo & 55,23 & 38,66 & 50,84 \\
Santa M$^{-a}$ de Jetibá & 32,09 & 19,05 & 34,00 \\
Posição estadual* $^{*}$ & $7^{\circ}$ menor & 7 menor & $6^{\circ}$ menor \\
\hline
\end{tabular}

Fonte: Atlas do Desenvolvimento Humano, 2013.

*O Estado do Espírito Santo é composto por 78 municípios.

Apesar dos dados disponíveis não separarem a população rural da urbana, o baixo índice de urbanização do município acaba influenciando pouco nos resultados dos indicadores e certamente os níveis de escolarização da população rural seriam somente um pouco menores em relação aos dados da população total. 
No trabalho de campo ficou evidente o baixo nível de escolarização. Os agricultores familiares mais velhos frequentaram a escola por no máximo 4 anos e na época em que estudaram não haviam escolas próximas para darem continuidade aos estudos. Já os agricultores mais jovens contaram com a disponibilidade de escolas e estudaram um pouco mais, mas abandonaram a escola cedo para trabalharem na propriedade da família.

Em um contexto de elevado índice de população rural e baixo nível de instrução, contraditoriamente verifica-se uma baixa taxa de fertilidade total. No trabalho de campo constatou-se que a maioria dos casais mais jovens, com menos de 40 anos, tem ou terá no máximo dois filhos.

O antagonismo dos indicadores tem estreita relação com a acentuada valorização do trabalho presente entre os agricultores familiares do município. Valorização essa que influencia não somente a taxa de fecundidade, mas também a duração das jornadas de trabalho e a utilização da mão de assalariada, quer seja permanente quer seja temporária. A explicação para a supervalorização do trabalho tem raízes históricas e culturais e remete também ao processo de formação do território que hoje corresponde ao município e que foi parte de uma colônia de imigrantes estrangeiros.

A representação do trabalho para esses imigrantes e seus descendentes ocupa uma posição diferente em relação aos homens livres no Brasil, onde o desenvolvimento do trabalho livre se deu no âmbito de uma sociedade latifundiária e escravista, na qual para os trabalhadores "livres, na medida em que o cativeiro fosse o referencial do processo produtivo, só poderiam conceber o trabalho organizado como a forma mais degradada de existência" (KOWARICK, 1994, p. 41). Na mesma perspectiva, Colbari (1997) afirma que

as representações sobre o trabalho na imaginação coletiva tinham como substrato a escravidão, o cativeiro, a degradação do trabalho manual e o aviltamento da condição de trabalhador. Configurava-se, desta forma, uma cultura do trabalho, carente dos parâmetros materiais e ideológicos da tradição artesanal e da ética puritana. O legado da escravidão no processo histórico brasileiro foi responsável pela afirmação de uma concepção negativa do trabalho na cultura nacional, com conotação pejorativa. (p. 3)

Relacionada à escravidão, tal concepção degradante do trabalho foi insignificante no processo histórico de formação territorial de Santa Maria de Jetibá, 
uma vez que o município foi parte de uma colônia de imigrantes estrangeiros. Estes tiveram acesso à terra na forma de pequenas propriedades onde todo o trabalho era realizado pela família e a utilização da mão de obra do escravo não era permitida. Era justamente a combinação do trabalho da família com a propriedade da terra que possibilitava ao imigrante a oportunidade para acumular algum bem material. Diferindo-se do imigrante, no imaginário social nacional foi ausente

o artefato ideológico que, na formulação liberal clássica, associou trabalho a riqueza, prosperidade, participação e cidadania, o trabalho não aparece como condição para uma vida melhor, mas como negação da liberdade e marca da inferioridade social (COLBARI, 1997, p.3).

Para o imigrante das colônias o trabalho manual não tinha uma representação degradante e na condição de um trabalhador livre, esse sujeito social apresentava uma particularidade: não se tratava de um trabalhador despojado da propriedade, mas de um pequeno proprietário de terra. Na produção organizada pelo capital é necessário o despojamento da propriedade para que o trabalhador livre venda a única propriedade que lhe resta, ou seja, a sua força de trabalho. Dessa forma, ao analisar o trabalho livre e compulsório nas fazendas de café paulistas, Martins (1990) afirma que

Para o escravo, a liberdade não é o resultado imediato do seu trabalho, isto é, trabalho feito por ele mas que não é seu. A liberdade é o contrário do trabalho, é a negação do trabalho, ele passa a ser livre para recusar a outrem a força de trabalho que agora é sua. Para o homem livre, despojado dos meios de produção, ao contrário, o seu trabalho passa a ser condição de liberdade (p.17).

Apesar de ser livre para vender a sua força de trabalho, o imigrante da colônia de Santa Leopoldina não se enquadrava nessa situação de despojado e trabalhava de forma autônoma em conjunto com sua família. E assim permaneceram as gerações subsequentes até chegar aos dias atuais. Com esse passado histórico, os agricultores familiares de Santa Maria de Jetibá, majoritariamente descendentes desses imigrantes, sobretudo dos pomeranos, construíram uma representação de trabalho que não passa pela degradação do homem, mas que enobrece e possibilita a mobilidade social. "Trabalhar para ter alguma coisa na vida" é o objetivo principal desses agricultores, que acreditam veementemente que o trabalho vai possibilitar a mobilidade social. 
Outro aspecto importante acerca da valorização do trabalho refere-se à dimensão étnica do trabalho, identificada por SCHNEIDER (1999) ao analisar os trabalhadores-antigos, ex-colonos de descendência alemã, na indústria coureirocalçadista do Rio Grande do Sul.

A noção de que o trabalho faz parte da identidade do grupo social ou que este grupo pode ser reconhecido pelo modo que o exerce é amplamente difundida entre os descendentes de alemães da região da Colônia Velha alemã. $O$ trabalho identifica a etnia germânica, sendo um de seus principais atributos. Essa característica ao mesmo tempo que identifica o grupo social entre si diferencia-o em relação aos demais (SCHNEIDER, 1999, p. 125).

Mesmo que a descendência eslava e não a germânica seja predominante entre os agricultores familiares de Santa Maria de Jetibá, o trabalho também é um elemento da identidade desses agricultores, majoritariamente descendentes de imigrantes pomeranos.

Ao longo das várias gerações alguns elementos sociais e culturais desse grupo étnico foram mantidos e até mesmo reforçados, o que acaba também exercendo influência na valorização do trabalho. Constatou-se que na zona rural a população descendente de pomeranos é quase absoluta; o pomerano é mais falado que o português e as crianças, mesmo assistindo aos programas de televisão em português, ainda aprendem a falar primeiramente o pomerano; a religião luterana é seguida pela maioria dos agricultores familiares; os casamentos intragrupais ainda são recorrentes e os agricultores familiares consideram que não "combina" muito bem quando os casamentos não ocorrem entre os descendentes de pomeranos. Esses imigrantes e seus descendentes, no caso específica de Santa Maria de Jetibá,

Ficaram instalados em regiões denominadas "frias", com terras altas entre 300 e 1450 metros acima do nível do mar e com péssimas estradas. Ali, devido ao difícil acesso a outras localidades, permaneceram. Nessas regiões não ocorreram casamentos com outros grupos étnicos, até 1920. Dessa maneira, as comunidades mantiveram suas tradições, e a língua pomerana foi falada por todos com muita facilidade (HEINEMANN, 2008, p. $6)$.

Nesse contexto em que há um certo fechamento do grupo étnico e distante das condições que degradavam o trabalho organizado pelo capital, ao longo das várias gerações foi construída e reforçada entre esses agricultores uma supervalorização do trabalho. E essa valorização do trabalho como a possibilidade 
de mobilidade social, foi concebida pelo próprio imigrante e seus descendentes, mas apropriada pelo comércio.

Para um casal de agricultores familiares aposentados, mas que ainda cumpria uma jornada de trabalho de 8 horas diárias, "o trabalho é a felicidade e ficar sem fazer nada não tem graça". Tal percepção se deve ao fato de que por meio do trabalho foi possível melhorar e ampliar a produção, construir uma casa de alvenaria bem mais confortável que a pretérita, definida pelo casal como um paiol, comprar carro e outros bens de consumo e, dessa forma, melhorar bastante a realidade financeira da família.

Ainda sobre a valorização do trabalho, verifica-se uma inversão das representações comuns em uma sociedade capitalista. Trabalhar passa a ter "graça" e ócio a ser "sem graça", porque para esses agricultores "a ética do trabalho expressa a centralidade da atividade do trabalho em sua existência, transfigurando a necessidade do trabalho na realização de um prazer" (SANTOS, 1978, p. 141 e 142).

Esses agricultores começaram a trabalhar desde a infância. As crianças, ainda bebês, são criadas no meio das lavouras e hoje é comum serem acomodadas dentro das caixas usadas para armazenar hortaliças. Atualmente, num período do dia as crianças frequentam a escola e em outro podem trabalhar ou não, mas a jornada é pequena (duas ou três horas) e as tarefas menos pesadas. No entanto, naturalmente as crianças são inseridas no trabalho.

Por sua vez, os agricultores familiares se submetem a longas jornadas de trabalho, com duração média entre 10 a 12 horas diárias, de segunda-feira a sábado, podendo se estender até aos domingos dependendo da cultura e da etapa do ciclo produtivo. Há entre eles o reconhecimento de que a jornada de trabalho é longa, mas consideram normal trabalhar muitas horas por dia por ser essa a condição necessária para sobreviver e acumular algum bem material ao longo da vida.

Os agricultores familiares não buscam assegurar somente a reprodução simples da família/propriedade, mas uma reprodução ampliada, mesmo que em pequena escala. "Juntar dinheiro", "ter alguma coisa na vida", aumentar o patrimônio da família", "construir alguma coisa", são objetivos arraigados na identidade desse grupo social. Como acreditam que o trabalho possibilita a mobilidade social, os 
agricultores familiares veem naqueles que prosperaram um pouco mais, um exemplo e estímulo para crescerem economicamente. Essa extrema valorização do trabalho é uma das principais condicionantes do crescimento da produção agrícola, especialmente as hortaliças.

A exposição às longas jornadas de trabalho tem estreita relação com a acentuada subordinação da produção ao comércio. Tanto a jusante quanto amontante, a produção agrícola dos agricultores familiares, sobretudo a de hortaliças, está intensamente subordinada ao comércio, conforme será abordado mais adiante neste trabalho. Cada vez mais dependentes dos insumos industriais e subordinados ao comércio, para sobreviver ou acumular, o agricultor e sua família têm que se submeter às longas jornadas de trabalho.

Dessa forma, o produto do trabalho está subordinado diretamente ao capital, o que acaba também influenciando e subordinando indiretamente a organização do trabalho da família. A autonomia do trabalho familiar, que isenta da relação patrão e empregado e é tão valorizada pelos agricultores familiares, na verdade obscurece a subordinação indireta do trabalho ao capital, uma vez que

\begin{abstract}
Essa autonomia do trabalho é uma espécie de pedra fundamental da ideologia do trabalho sobretudo porque ela encobre e obscurece o conteúdo principal da relação entre patrão e o empregado. Por meio dela, o trabalho não é considerado principalmente como uma atividade que enriquece a burguesia. [...] A riqueza, no sentido de capital acumulado, torna-se aceitável e legítima porque é produto do trabalho e porque o trabalho é concebido como uma "virtude" universal (MARTINS, 1990, p. 133).
\end{abstract}

No entanto, em Santa Maria de Jetibá o trabalho familiar enriquece prioritariamente a classe constituída pelos comerciantes. Decorrente dos baixos preços pagos ao produto do trabalho familiar, somente estendendo a jornada de trabalho é possível assegurar a sobrevivência da família. Como o trabalho familiar não é mediado pelo salário, essa é a forma encontrada pelo capital para capturar o excedente produtivo e subordinar indiretamente o trabalho desses agricultores.

Face a longa duração da jornada de trabalho, superior a 10 horas diárias, os agricultores familiares recorrem muito pouco à contratação de mão de obra assalariada temporária e tampouco a permanente. Consideram que esses trabalhadores têm uma jornada de trabalho muito curta, "começa às 7 h e para às 
5h". Mesmo que esse trabalhador cumpra 9 horas diárias, segundo o agricultor familiar não compensa utilizar essa mão de obra.

Dessa forma, aqueles agricultores que precisam contratar mão de obra optam pela parceria em detrimento do trabalho assalariado. Como na parceria o rendimento é em produto e quanto mais se trabalha maior a remuneração, torna-se uma relação de trabalho atraente para o contratante. Esse parceiro, da mesma forma que os agricultores familiares, vai se submeter a uma longa jornada de trabalho bem maior que as 9h diárias de um trabalhador assalariado.

Geralmente o contratante compra a produção dos parceiros trabalhadores e, dessa forma, apropria-se em dois momentos do excedente produtivo. Primeiramente se apropria do excedente produtivo resultante do trabalho extra das longas jornadas e em segundo lugar na compra da produção, quando desempenha a função de comerciante.

Apesar da parceria não ser uma relação de trabalho determinante e de representar somente $4,18 \%$ dos produtores agrícolas do município (IBGE, 2006), assume relevância pelas diferenciadas formas em que se manifesta em Santa Maria de Jetibá.

A primeira forma de parceria é a tradicionalmente praticada no Espírito Santo e estabelecida entre o proprietário da terra e o trabalhador. O proprietário disponibiliza a terra, os insumos e os equipamentos necessários para a produção e o trabalhador cede a força de trabalho, que pode ser individual ou da família. 0 produto da relação é dividido entre as partes, cabendo ao trabalhador entre $40 \%$ a $50 \%$ do total produzido. Trata-se de uma relação não capitalista de produção, uma vez que não é mediada pela categoria salário. Verifica-se que os rendimentos são obtidos em produto tanto pelo proprietário da terra quando pelo trabalhador.

A segunda forma de parceria é celebrada entre um proprietário de terra e um proprietário de terra comerciante. O primeiro disponibiliza a terra e a força de trabalho individual ou da família, o segundo oferece os insumos, máquinas e equipamentos e assegura a compra da produção. A produção é dividida da seguinte forma: $60 \%$ para o proprietário trabalhador e $40 \%$ para o proprietário comerciante. Com receio de tomarem o crédito rural para financiar a produção agrícola e de perderem a produção por não conseguirem realizar a venda, o proprietário e trabalhador se submete a 
esse tipo de relação de parceria no qual o produto do seu trabalho é fortemente subordinado ao comércio.

A terceira forma de parceria é celebrada entre o arrendatário de terra e o trabalhador. O arrendatário é um sujeito social pouco comum no espaço rural do Espírito Santo e em Santa Maria de Jetibá se diferencia por desempenhar múltiplas funções, uma vez que ao mesmo tempo é comerciante (atravessador), proprietário de terra e estabelece o contrato de parceria com trabalhadores. $O$ parceiro arrendatário oferece a terra, os insumos, as máquinas e equipamentos e o parceiro trabalhador a força de trabalho individual ou da família. O trabalhador recebe $40 \%$ do produto e o arrendatário $60 \%$.

\subsection{Meios de produção}

\subsubsection{A propriedade fundiária: o predomínio da pequena propriedade historicamente constituída}

A Lei de Terras aprovada em 1850 instituiu um novo regime fundiário em substituição ao regime das sesmarias, extinto a partir da independência do país em 1822. Esse novo regime fundiário, ao tornar possível o acesso à propriedade da terra somente por meio da compra, teve dupla função: de um lado reforçou a expansão e a permanência da grande propriedade, um elemento estruturante da sociedade brasileira e, de outro lado, excluiu a classe trabalhadora do acesso a esse meio de produção. Dessa forma, tal legislação consistiu em um mecanismo arquitetado pela classe latifundiária, uma vez que

\footnotetext{
longe de ter como objetivo a liberalização do acesso à terra, teve por objetivo justamente o contrário; instituir bloqueios ao acesso à propriedade por parte dos trabalhadores, de modo que eles se tornassem compulsoriamente força-de-trabalho das grandes fazendas (MARTINS, 1999, p.76).
}

Apesar do nítido favorecimento da grande propriedade concedido pela Lei de Terras, no Espírito Santo os impactos de tal legislação manifestaram-se de forma um pouco diferenciada. Conforme abordado na capitulo 1, no âmbito da transição do trabalho compulsório para a mão de obra livre, houve a expansão da pequena propriedade e a fragmentação de várias fazendas. O acesso à terra na forma de 
pequenas propriedades rurais não foi bloqueado, mas permitido ao imigrante estrangeiro pela política de núcleos coloniais do governo imperial e estadual e também a trabalhadores nacionais.

Nas décadas iniciais da república o governo estadual deu sequência à política de criação de núcleos coloniais e também promoveu a colonização esparsa, criando, oportunamente, um conjunto de legislações estaduais e medidas administrativas para subsidiarem a implementação da política de terras do Espírito Santo. Havia interesse do Estado em regularizar a propriedade fundiária, exigida a partir da lei de terras e de sua regulamentação, e em arrecadar fundos com a venda das terras devolutas.

Da mesma forma que no país, no Espírito Santo houve a concessão de uma série de vantagens no processo de regularização da propriedade fundiária, sobretudo para as classes mais abastadas, bem como, a ação estadual foi insuficiente para coibir um conjunto de irregularidades cometidas na apropriação das terras devolutas. Segundo Moreira (2003), os pequenos posseiros por serem mais vulneráveis buscavam regularizar suas terras, enquanto os grandes evitavam a legalização das posses e tentavam tirar proveito dessa situação. Dessa forma, durante a República Velha, ocorreu

\begin{abstract}
O desenvolvimento de uma rede de corrupção, envolvendo funcionários, autoridades e fazendeiros e, como produto desse processo, parte significativa das terras devolutas eram privatizadas (griladas) em benefício de segmentos sociais e políticos influentes. [...] Existem fortes indicações que o problema da privatização das terras públicas por meios legais e ilegais, mas sempre sem o recurso ao pagamento pelas mesmas, foi bem maior do que o governo deixou de ventilar [...] Essa situação prejudicou e, no limite até mesmo inviabilizou, em determinadas sub-regiões, a ação do governo na arena da "colonização esparsa", isto é, as vendas avulsas de lotes a pequenos posseiros, como também a colonização graças ao desenvolvimento de núcleos coloniais (MOREIRA, s.p., 2003)
\end{abstract}

Em que pese a fragilidade do Estado em desmontar tal rede de corrupção, o predomínio da iniciativa privada e o favorecimento dos segmentos mais abastados na regularização da propriedade da terra, não se pode negligenciar que esse mesmo Estado teve importante função na promoção do acesso à terra na forma de pequenas propriedades, uma vez que "o desenvolvimento da pequena propriedade não estava interditado, desde que os lavradores fossem capitalizados o suficiente para arcar 
com os custos da compra ou demarcação e medição dos lotes" (MOREIRA, s.p., 2003).

Quando comparado aos estados cafeicultores vizinhos, o ritmo da ocupação espacial do Espírito Santo foi bem lento, de forma que na transição do trabalho compulsório para a mão de obra livre havia grande disponibilidade de terras devolutas para serem apropriadas, pois

\begin{abstract}
Diversamente da região cafeeira fluminense, na qual a terra já havia sido inteiramente ocupada à época da Abolição, ou do Oeste, onde ela foi monopolizada pelo capital em seu avanço em direção às terras novas, no Espírito Santo a transição se fez com a existência de vastas áreas devolutas, que o capital disponível para a produção de café não foi suficiente para ocupar (SALETTO, p. 116, 1996b).
\end{abstract}

Nessa época no Espírito Santo havia grande disponibilidade de terras devolutas e um efetivo diminuto de população. Em 1888, 85\% das terras eram devolutas (ALMADA, 1981) e em 1890 a população era de somente 135.997 habitantes, enquanto a de São Paulo e Rio de Janeiro era dez vezes superior (IBGE, 1890).

Nesse contexto, a formação do mercado de terras desenvolveu-se lentamente no Espírito Santo e o preço cobrado pelo Estado era baixo. Segundo Saletto (1996b), entre 1909 e 1912, o preço do hectare de terra variava entre $2 \$ 000$ e $10 \$ 000$ e nesse mesmo período a diária de um trabalhador oscilava de $1 \$ 000$ a $2 \$ 500$. Em 1918 o preço da terra elevou-se para $15 \$ 000$ e em 1921 para $20 \$ 000$ (SALETTO, 1996b). Nesses preços não estavam incluídas as despesas com a medição dos terrenos.

Considerando o grande bloqueio estabelecido pela lei de terras no país, verifica-se que no Espírito Santo as oportunidades de acesso à propriedade da terra concedidas aos pequenos posseiros e trabalhadores foram maiores. Sem desconsiderar as vantagens concedidas à classe mais abastada e todos o aparato de corrupção em torno da regularização da propriedade da terra, verifica-se que "O governo realizava vendas de pequenas propriedades em condições especiais: a prazo, a preço mais baixo e, finalmente, mediante concessão de lotes gratuitos com a obrigação de pagar a medição dois anos depois" (SALETTO, p. 123,1996b).

Sobre o acesso à terra, Wagemann (1949) constatou que normalmente um nativo, "o homem de cor", é o pioneiro e se apossa de uma área, começa a desbravá- 
la e cultivá-la, mas não detém a propriedade jurídica. Em seguida o colono em busca de uma terra para si ou o para o filho, propõe uma indenização ao posseiro pelas benfeitorias realizadas. $O$ posseiro aceita a proposta e busca uma outra área para se apossar. O colono demarca a área e posteriormente solicita ao governo a regularização (WAGEMANN, 1949).

Ocorre que as terras do território que corresponde no presente à Santa Maria de Jetibá, não eram as mais atrativas. Essas terras, de altitude elevada, não eram favoráveis ao cultivo do café, que na época era a única cultura com valor comercial; a fertilidade natural dos solos era baixa e a declividade dos terrenos acentuada. Esses aspectos naturais contribuíam para que os terrenos fossem menos atrativos e consequentemente apresentassem preços menores, o que tornava mais fácil para a classe trabalhadora o acesso à propriedade da terra.

Por sua vez, decorrente da política do governo imperial de criação de núcleos coloniais e da política estadual de terras nas décadas iniciais da república, constituiuse no Espírito Santo uma estrutura fundiária bem menos concentrada que o contexto nacional. Conforme os indicadores disponíveis nas últimas décadas, o Espírito Santo vem apresentando o menor ou o segundo menor índice de concentração fundiária do país (HOFFMAN,1998).

Considerando que todo o município de Santa Maria de Jetibá resulta dessas políticas de acesso à terra que favoreceram a pequena propriedade, sua estrutura fundiária é ainda bem melhor distribuída que a do Espírito Santo. O município apresenta estrutura fundiária muito pouco concentrada, sobretudo quando se considera que o contexto nacional é determinado pela grande propriedade. Entre 1995/95 e 2006 o índice de Gini do município caiu de 0,510 para 0,486 (IBGE, 2006)

Conforme pode ser observado na tabela 20 , entre as três instâncias administrativas, Brasil, Espírito Santo e Santa Maria de Jetibá, há uma acentuada diferença na forma como está distribuída a propriedade da terra. Santa Maria de Jetibá e Brasil estão em posição opostas, de forma que a área ocupada pelas propriedades com menos de 20 ha representa $40,91 \%$ e 5,31\% respectivamente. De outro lado, a área ocupada pelas propriedades com mais de 200ha representa em Santa Maria de Jetibá somente $0,6 \%$, enquanto no Brasil o indicador é $70,06 \%$. Nas duas situações o Espírito Santo ocupa uma posição intermediária. 
Tabela 20

Brasil, Espírito Santo e Santa Maria de Jetibá: estrutura fundiária - 2006

\begin{tabular}{l|c|c|c|c|c|c}
\hline \multirow{2}{*}{ Grupos de área } & \multicolumn{2}{|c|}{ Brasil } & \multicolumn{2}{c|}{ Espírito Santo } & \multicolumn{2}{c}{ Santa Maria de Jetibá } \\
\cline { 2 - 8 } & $\begin{array}{c}\text { Estab. } \\
(\%)\end{array}$ & $\begin{array}{c}\text { Área } \\
(\%)\end{array}$ & $\begin{array}{c}\text { Estab. } \\
(\%)\end{array}$ & $\begin{array}{c}\text { Área } \\
(\%)\end{array}$ & $\begin{array}{c}\text { Estab. } \\
(\%)\end{array}$ & $\begin{array}{c}\text { Área } \\
(\%)\end{array}$ \\
\hline 0 menos de 5 & 37,41 & 0,99 & 27,94 & 2,10 & 31,77 & 5,77 \\
5 menos de 10 & 12,93 & 1,34 & 20,12 & 4,35 & 23,24 & 11,52 \\
10 menos de 20 & 14,97 & 3,08 & 19,75 & 8,13 & 23,36 & 23,62 \\
20 menos de 50 & 17,15 & 7,83 & 19,86 & 18,10 & 18,18 & 39,73 \\
50 menos de 100 & 7,94 & 7,94 & 7,01 & 14,01 & 2,91 & 13,94 \\
100 menos de 200 & 4,46 & 8,76 & 3,01 & 12,13 & 0,52 & 4,83 \\
Acima de 200 & 5,13 & 70,06 & 2,31 & 41,17 & 0,02 & 0,60 \\
Total & 100 & 100 & 100 & 100 & 100 & 100 \\
\hline
\end{tabular}

Fonte: IBGE/Censo Agropecuário, 2006.

No espaço rural de Santa Maria de Jetibá a pequena propriedade rural, historicamente constituída, manteve-se e é predominante. Conforme pode ser visualizado na tabela $21,78,37 \%$ das propriedades têm área inferior a 20ha, ou seja, menor que o lote colonial recebido pelo imigrante que era de $25 \mathrm{ha}$ em média. Atualmente as propriedades tem áreas bem inferiores, mais da metade tem menos de 10 ha, o que indica que ao longo dos anos ocorreu um processo de fragmentação. Embora os dados do Censo Agropecuário apontem para uma estabilização entre 1995/96 e 2006, esses indicadores devem ser observados com uma certa reserva.

Tabela 21

Santa Maria de Jetibá: estrutura fundiária (1995/96 e 2006)

\begin{tabular}{|c|c|c|c|c|c|c|c|c|c|c|}
\hline \multirow{3}{*}{$\begin{array}{c}\text { Grupos de Área } \\
\text { (ha) }\end{array}$} & \multicolumn{5}{|c|}{$1995 / 96$} & \multicolumn{5}{|c|}{2006} \\
\hline & \multicolumn{2}{|c|}{$\begin{array}{l}\text { Estabele- } \\
\text { cimentos }\end{array}$} & \multicolumn{3}{|c|}{ Área } & \multicolumn{2}{|c|}{$\begin{array}{l}\text { Estabele- } \\
\text { cimentos }\end{array}$} & \multicolumn{3}{|c|}{ Área } \\
\hline & $\left(\mathrm{n}^{\circ}\right)$ & $(\%)$ & (ha) & $(\%)$ & Média & $\left(\mathrm{n}^{\circ}\right)$ & $(\%)$ & (ha) & $(\%)$ & Média \\
\hline 0 a menos de 5 & 1234 & 35,11 & 2888 & 5,73 & 2,3 & 1344 & 31,77 & 3280 & 5,57 & 2,4 \\
\hline 5 a menos de 10 & 670 & 19,07 & 4451 & 8,83 & 6,6 & 983 & 23,24 & 6549 & 11,52 & 6,7 \\
\hline 10 a menos de 20 & 711 & 20,23 & 9764 & 19,36 & 13,7 & 988 & 23,36 & 13432 & 23,62 & 13,6 \\
\hline 20 a menos de 50 & 737 & 29,97 & 21609 & 42,86 & 29,3 & 769 & 18,18 & 22587 & 39,73 & 29,4 \\
\hline 50 a menos de 100 & 144 & 4,10 & 9057 & 17,96 & 62,9 & 123 & 2,91 & 7923 & 13,94 & 64,4 \\
\hline 100 a menos de 200 & 14 & 0,40 & 1742 & 3,45 & 124,4 & 22 & 0,52 & 2744 & 4,83 & 124,7 \\
\hline 200 a menos de 500 & 4 & 0,11 & 911 & 1,81 & 227,8 & 1 & 0,02 & 341 & 0,60 & 341,0 \\
\hline Total & 3514 & 100 & 50422 & 100 & 14,3 & 4230 & 100 & 56856 & 100 & 13,4 \\
\hline
\end{tabular}

Fonte: IBGE/Censo Agropecuário, 1995/96 e 2006.

$\mathrm{Na}$ pesquisa de campo constatou-se que a principal forma de acesso a propriedade da terra é por meio da herança (90\%). Das propriedades herdadas, 
quase metade (44\%) teve a área ampliada por meio da compra, mas em proporção insuficiente para reduzir a fragmentação. No entanto, o processo de fragmentação das propriedades ainda não tem inviabilizado a reprodução dos agricultores familiares.

Ocorre que a utilização da propriedade foi bastante alterada e grande parte da área ocupada pela cafeicultura passou a ser utilizada pelos cultivos de hortaliças. Em outras palavras, substituiu-se uma cultura que demandava mais terra por outras que requerem menos área para assegurar a reprodução da família. Dessa forma, essa substituição, embora não planejada, contribuiu diretamente para viabilizar a reprodução das famílias de agricultores em propriedades menores.

Perante o processo de fragmentação ocorrido, o interesse em aumentar a área da propriedade manifesta-se somente quando o seu tamanho ameaça a sobrevivência da família e das gerações futuras. Embora $85 \%$ dos agricultores sejam proprietários, a propriedade da terra para um agricultor familiar se diferencia da propriedade capitalista. "A propriedade familiar não é propriedade de quem explora o trabalho de outrem; é propriedade direta de instrumentos de trabalho por parte de quem trabalha. Não é propriedade capitalista; é propriedade do trabalhador" (MARTINS, 1991, p. 54).

Como propriedade do trabalhador, se a capacidade de trabalho da família não for suficiente para expandir a área da propriedade, não há interesse na sua ampliação. A terra, mesmo propriedade privada, para esses agricultores não é terra de negócio, mas terra de trabalho. "Quando o capital se apropria da terra, esta se transforma em terra de negócio, em terra de exploração do trabalho alheio; quando o trabalhador se apossa da terra, ela se transforma em terra de trabalho" (MARTINS, 1991, p. 55).

Essa terra, mesmo que de trabalho, é propriedade privada e passou por intenso processo de elevação dos seus preços. O ponto central dessa elevação foi a introdução dos cultivos comerciais de hortaliças e a incorporação de inovações agrícolas, que tornou o trabalho mais produtivo. Para assegurar a reprodução de uma família, a nova atividade desenvolvida em bases modernas de produção passou a demandar bem menos área que o café. Acrescente-se também que a adaptação da nova atividade foi facilitada pela altitude mais elevada da região onde está 
localizada Santa Maria de Jetibá, que Ihe confere temperaturas menores e favoráveis ao cultivo de uma ampla variedade de hortaliças.

Nessa terra em que 1 ha pode oscilar entre $R \$ 10.000,00$ e $R \$ 100.000,00$, interferem também no seu preço os seguintes aspectos: a) a localização no interior do município; b) a fertilidade natural dos solos que é corrigida pelo emprego de fertilizantes; c) a disponibilidade de água, um recurso natural abundante no município que dispõe de uma densa rede hídrica; d) a declividade dos solos, um aspecto natural de extrema importância e que no município é bastante elevada e limita a utilização da muitas áreas.

Ocorre que a terra é um bem natural não produzido pelo trabalho humano e finito, em outras palavras, não é possível fabricar novas terras. No caso da agricultura, excluindo os raros casos de exceção, a terra assume a particularidade de ser um meio de produção fundamental e não somente um substrato físico para receber uma determinada cultura. "O processo produtivo agrícola requer uma interação com o solo, o qual não tem um papel passivo como na indústria: além do substrato, ele fornece a "alimentação" das plantas e, indiretamente, dos animais" (SILVA, 2003, p. 30).

À medida que esse bem finito e não passível de reprodução encontra-se plenamente apropriado privadamente, isso significa que o acesso à propriedade da terra só será possível se algum proprietário disponibilizá-la para a venda. Assim disponível, para adquirir a propriedade da terra paga-se um preço que consiste na renda da terra, que "nada mais é do que a remuneração pelo direito de uso da terra imposto ao capital" (BUZANELO; CARIO, 1986, p. 34). No momento da compra paga-se antecipadamente pela possibilidade futura de utilização produtiva dessa terra uma renda capitalizada, pois

Quando o capitalista compra a terra, ele converte o seu capital em renda capitalizada, renda antecipada, em direito de extrair uma renda da terra e ao mesmo tempo direito de recobrar inteiramente e até com acréscimo o seu capital (MARTINS, 1983, p.167).

No caso de Santa Maria de Jetibá, a figura do capitalista é exceção pois predominam agricultores familiares. Para esses agricultores a principal forma de acesso à terra se dá por meio do recebimento da herança, o que implica em não pagamento pela renda da terra pelo herdeiro. No entanto, muitos agricultores 
familiares ampliam a propriedade herdada e outros adquirem a terra somente por meio da compra, ou seja, pagando pela renda da terra.

Esses agricultores não são capitalistas, mas trabalhadores que fazem a terra produzir riqueza sem explorar o trabalho alheio, de forma que o dinheiro empregado na compra da propriedade, no pagamento da renda da terra, não é proveniente da distribuição da mais-valia. Esse dinheiro é proveniente principalmente da remuneração pelo trabalho realizado pela família, acumulados ao longo de muitos anos de trabalho e por privação do consumo, em outras palavras, uma acumulação por privação.

Embora sejam usadas para a produção de alimentos, as terras de Santa Maria de Jetibá têm preços elevados porque a produtividade do trabalho também é elevada. No entanto, é importante salientar que essas terras não são atrativas para determinados agricultores e atividades. São terras onde predominam serras como forma de relevo e declividade acentuada, o que por sua vez, limita a incorporação de inovações mecânicas e a contiguidade dos cultivos.

Para aquelas atividades agrícolas cultivadas em grandes extensões de terra, plenamente mecanizadas e assentadas no trabalho assalariado, as terras de Santa Maria de Jetibá não são atrativas. Mas, por outro lado, essas terras "não atrativas" atendem as necessidades produtivas da agricultura familiar. Dessa forma, tanto as raízes históricas da formação de Santa Maria de Jetibá quanto a não atratividade contribuem para explicar a permanência de uma estrutura fundiária pouco concentrada.

\subsubsection{Progresso técnico: incorporação e sujeição}

A agricultura é um setor da economia que se particulariza porque, mesmo incorporando uma ampla gama de inovações tecnológicas, sua produção não só depende das condições naturais, mas também se desenvolve assentada em processos biológicos. Diferentemente do processo produtivo industrial, na agricultura "a transformação da matéria prima em mercadoria não é realizada exclusivamente pelo trabalho humano, mas sim através da combinação de seu exercício com o seu ritmo biológico" (MARTINS, 2004, p.76 e 77). 
Ocorre que o trabalho é influenciado pelos processos biológicos, os quais em interação com as condições naturais, determinam o ciclo produtivo agrícola e, por sua vez, conferem algumas particularidades ao processo produtivo da agricultura quando comparada ao industrial. Na indústria o processo produtivo é isolado das condições naturais e caracteriza-se pela simultaneidade do trabalho, ou seja, todas as etapas da produção ocorrem ao mesmo tempo e uma não depende da outra para ser realizada. Dessa forma, não só o trabalho se torna especializado e mais produtivo, mas o tempo de produção também é acelerado. Do ponto de vista do capital, sua circulação torna-se mais rápida.

Já na agricultura, por ser determinado pelos processos biológicos, o ciclo produtivo é sequencial e contínuo, de forma que cada etapa da produção é realizada em períodos diferentes e uma é dependente da outra. Em outras palavras, obedecendo a sequência do ciclo natural, uma etapa só se inicia após a conclusão da anterior. Isso ocorre porque

como os processos de produção biológicos são sempre contínuos, não permitem que as partes se tornem independentes do todo. [...] a continuidade dos processos biológicos impõe que haja um tempo para plantar, outro para crescer e outro para colher (SILVA, 2003, p. 25).

Dessa forma, no decorrer do ciclo produtivo agrícola ocorrem os tempos de trabalho e os tempos de não-trabalho. De um lado, os tempos de trabalho consistem nas atividades realizadas pelo trabalhador como o plantio, a fertilização, a pulverização, a poda e a colheita. Do outro lado, os tempos de não-trabalho ocorrem quando o capital espera a natureza agir, ou seja, germinar, crescer, madurar os frutos, etc. Dessa forma,

Do ponto de vista do capital, os tempos de não-trabalho são períodos em que ele não está sendo valorizado, em que ele está "parado"; representando um prolongamento "desnecessário" do período de produção que se traduz numa menor velocidade de rotação do capital (SILVA, 2003, p. 27).

Como o ciclo produtivo é sequencial, podemos destacar algumas consequências. Primeiramente o trabalho na agricultura não é especializado, o que o torna menos produtivo. A segunda é que há uma dissociação entre o período de produção e o tempo de trabalho, sendo o primeiro bem superior ao segundo; a terceira é que a rotação do capital é mais lenta na agricultura. 
As particularidades do ciclo biológico associadas às condições naturais impõem alguns limites à incorporação de progresso técnico, o qual nem sempre é viável economicamente e adaptado a qualquer tipo de cultura e às variações regionais.

Considerando a classificação das inovações em mecânicas, físicoquímicas, biológicas e agronômicas (SILVA 2003), em que medida elas foram incorporadas na produção agrícola de Santa Maria de Jetibá, e de que forma os limites impostos pela natureza afetam o trabalho e, por sua vez, a valorização do capital na agricultura do município?

Primeiramente, as inovações mecânicas na agricultura interferem diretamente no trabalho. Considerando uma determinada atividade, a mecanização reduz o tempo de trabalho necessário, aumentando a produtividade do trabalho e o tempo de não trabalho, mas interfere de forma insignificante no tempo de produção, reduzindo em poucos dias um ciclo que dura vários meses.

Em Santa Maria de Jetibá algumas atividades e etapas do processo produtivo agrícola são mecanizadas. Como predominam os cultivos de hortaliças na produção agrícola, $73 \%$ das propriedades usam sistemas de irrigação, um percentual bastante elevado, considerando que a média nacional é de $6,41 \%$ e a estadual $29,62 \%$ (IBGE, 2006). No trabalho de campo todos os entrevistados declararam usar irrigação, mas usam essa inovação somente para os cultivos de hortaliças. As demais culturas, como o café e o eucalipto, não são irrigadas por não ser necessário.

A incorporação dos sistemas irrigação foi iniciada aproximadamente nos anos 1970, mas dependeu da instalação da rede de energia elétrica, um insumo chave não somente para a adoção de técnicas de produção, mas também para o bem-estar das famílias. Dessa forma, houve uma variação temporal e espacial na incorporação dessa inovação técnica.

Anteriormente à chegada de energia elétrica os sistemas de irrigação eram empregados somente em propriedades nas quais as condições naturais permitiam irrigar por gravidade ou usassem diesel como força motriz, mas com custo elevado. Alguns agricultores também chegaram a irrigar manualmente com mangueiras, mas a atividade demandava muito trabalho. 
Há uma grande disponibilidade hídrica no município, que é dotado de uma densa rede de drenagem. A água utilizada para a irrigação é proveniente de pequenos cursos d'água e raramente é necessário recorrer à construção de barragens.

A aspersão é o método de irrigação predominante, mas os agricultores não usam sistemas automatizados, o que demanda mais trabalho no uso desses equipamentos. Acrescente-se também que alguns agricultores ainda não têm tubulação suficiente para irrigar toda a área cultivada da propriedade e por isso é necessário a transferência dos tubos de uma área para outra, aumentando também a demanda de trabalho.

Essa inovação, ao substituir as chuvas, fornece o volume de água adequado a cada cultura e aumenta a produtividade, mas ao mesmo tempo, não se pode controlar o excesso de chuvas e as enchentes. Como exemplo, no final de 2013 fortes chuvas afetaram o município ocasionando a perda de grande parte da produção das culturas temporárias, com destaque para as hortaliças.

Em relação aos tratores, Santa Maria de Jetibá é o município do Espírito Santo que possui mais propriedades com esse tipo de máquina, tanto em termos relativos quanto absolutos. $31,92 \%$ das propriedades de Santa Maria de Jetibá possuem tratores, enquanto a média estadual é 11,29\%. Dessa forma, a posição do município está bem acima da média estadual e próximo das médias dos estados com agricultura mais moderna, como São Paulo (35,15\%) e Santa Catarina (29,56\%).

Dado o predomínio das culturas temporárias e de ciclo curto, os tratores e microtratores são bastante utilizadas, mas se limitam às atividades da etapa de preparação do solo e às áreas onde a declividade permite. Outras atividades como plantio, a fertilização, a pulverização, a capina e a colheita, que poderiam ser mecanizadas, são em realizadas manualmente. Ocorre que

Para os pequenos produtores, o novo padrão tecnológico [introduzido pela modernização da agricultura] não pode ser totalmente absorvido, especialmente no que diz respeito àqueles itens que dependem de uma escala mínima de produção, como, por exemplo, a mecanização. [...] a tendência de tecnificação dos pequenos produtores foi a de absorver as tecnologias físico-químicas num grau muito superior às tecnologias mecânicas (SILVA, 2003, p. 157). 
Esses aspectos da modernização manifestam-se em Santa Maria de Jetibá, onde identifica-se então dois limites para a incorporação de progresso técnico na produção agrícola: o primeiro, de caráter natural, é a declividade dos solos, conforme a Figura 18, que limita o processo de mecanização; o segundo, refere-se à dimensão da produção, cuja escala não é suficiente para comportar os investimentos necessários para o processo completo de mecanização. Dessa forma, tanto as condições naturais quanto a escala produtiva das pequenas propriedades, ao limitarem a mecanização, afetaram diretamente a produtividade do trabalho.

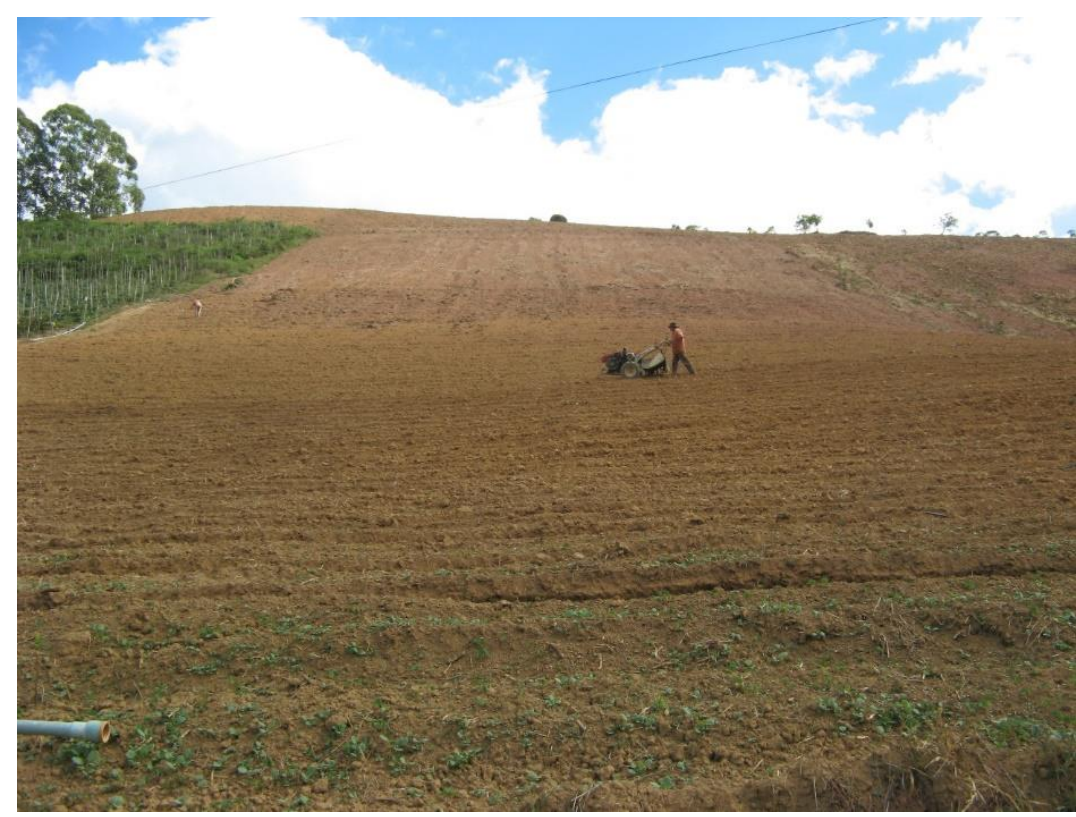

Figura 18 - Preparação do solo - Na frente, o agricultor mistura o fertilizante ao solo com uso de micro trator e ao fundo, outro agricultor utiliza enxada para realizar a mesma tarefa, pois a declividade acentuada impede a mecanização.

Diante dos limites à mecanização, a propriedade fundiária em Santa Maria de Jetibá, embora tenha prelo bastante elevado conforme abordado, não é atrativa para uma empresa capitalista assentada no trabalho assalariado e intensiva em inovações mecânicas. Uma das razões que explicam o elevado percentual de agricultores familiares e a estrutura fundiária desconcentrada do município, reside nos limites naturais impostos à mecanização. São essas terras que "restam" para os agricultores familiares, os quais para compensar a baixa produtividade do trabalho decorrente da mecanização parcial, submetem-se a extensas jornadas de trabalho.

Por sua vez, as inovações físico-químicas alteram as características naturais do solo e controlam as manifestações de pragas, doenças e ervas daninhas, 
afetando principalmente a produtividade dos solos e em menor intensidade a produtividade do trabalho. Se os fertilizantes aumentam diretamente a produtividade agrícola, os defensivos, ao protegerem as culturas das infestações de pragas e doenças e da concorrência das ervas daninhas, asseguram a manutenção da produtividade. Em outras palavras, para assegurar o melhor desempenho as inovações devem ser usadas em conjunto, o que revela o seu caráter interdependente.

Em Santa Maria de Jetibá as inovações físico-químicas foram plenamente incorporadas. O uso de fertilizantes orgânicos está relacionado à avicultura de postura e à medida que a atividade foi crescendo, maior tornou-se a oferta de esterco para a produção agrícola, sobretudo para o cultivo de hortaliças. Devido à oferta local desse insumo iniciada na década de 1960, antes mesmo do início da modernização da agricultura no Espírito Santo, a produção de hortaliças passou a incorporar o fertilizante orgânico, conferindo maior produtividade agrícola e do trabalho.

Em Santa Maria de Jetibá 90,25\% (IBGE, 2006) das propriedades utilizam fertilizantes, o que lhe confere a posição de município que mais incorpora o uso dessa inovação técnica no Estado. Na pesquisa de campo todos os agricultores declararam usar tanto o fertilizante orgânico quanto o químico, mas o primeiro é usado com mais intensidade. Os agricultores reconhecem a importância do fertilizante para conservação e o aprimoramento da qualidade dos solos, uma vez que "a aplicação de adubos orgânicos nos solos tropicais proporciona a melhoria dos seus atributos físicos, químicos e biológicos, obtendo-se respostas das plantas" (BORGES; SOUZA, 2011, p.191).

Embora seja elevado o percentual de uso de fertilizantes, a análise dos solos não é um recurso muito apropriado pelos agricultores. São os estabelecimentos comerciais especializados em produtos agropecuários os principais responsáveis pela realização das análises e também pela recomendação dos fertilizantes.

Acerca dos agrotóxicos, todos os agricultores entrevistados declararam fazer uso dessas substâncias. As hortaliças por serem cultivadas de forma intensiva e não sazonal, tornam-se bastante vulneráveis ao ataque de pragas, o que demanda maior emprego de agrotóxicos, pois 
Todas as hortaliças são exigentes na aplicação de defensivos, o que cria não só riscos de intoxicação de agricultores, mas também de consumidores, devido aos resíduos tóxicos nos alimentos. Isso acontece porque na maioria dos casos há poucas opções de controle de pragas além do controle químico (NAKANO, 1999, p.4).

Em termos absolutos o consumo de agrotóxicos nos cultivos de hortaliças é bem menor que na cultura da soja, mas em termos relativos é muito maior. Considerando apenas os fungicidas, o consumo dessa substância atingiria uma área de aproximadamente 800 mil ha de hortaliças, contra 23 milhões de ha de soja (ALMEIDA; CARNEIRO; VILELA, 2009). Dessa forma, "estima-se que a concentração de uso de ingrediente ativo de fungicida em soja no Brasil, no ano de 2008, foi de 0,5 litros por hectare, bem inferior a estimativa de quatro até oito litros por hectare em hortaliças, em média" (ALMEIDA; CARNEIRO; VILELA, 2009, sp).

Apesar de intensivamente usados nos cultivos de hortaliças, os agrotóxicos liberados para a atividade no país são poucos. Em termos absolutos o consumo de agrotóxico em hortaliças não é importante e "Diante das obrigações legais a que estão sujeitas perante o registro de um agrotóxico, as empresas registrantes direcionam seus esforços para aquelas culturas que possibilitam melhor relação custo-benefício" (CRUZ, 2013, s.p.). No caso de culturas como soja e cana-deaçúcar há uma grande oferta de agrotóxicos registrados, mas para as hortaliças não.

Nesse contexto, segundo dados da ANVISA, muitos alimentos estão contaminados sobretudo pelo uso de substâncias inadequadas (tabela 22). Alface, cenoura, morango, pepino e pimentão, alimentos cujas amostras apresentavam elevado percentual de insatisfatórios, são amplamente cultivados em Santa Maria de Jetibá. Ressalta-se que a maioria dos alimentos com resultados insatisfatórios refere-se ao uso de agrotóxicos não autorizados, pois os agricultores utilizam agrotóxicos liberados para outras culturas.

Apesar da importância econômica da agricultura em Santa Maria de Jetibá, a assistência técnica oferecida pelo município e pelo estado é insignificante. Para oferecer os serviços públicos de assistência técnica no município, o Instituto Capixaba de Pesquisa e Extensão Rural - INCAPER, dispõe de somente 4 técnicos e a Secretária Municipal de Agricultura 4 técnicos agrícolas, 1 engenheiro agrônomo e 2 assistentes rurais. 
Tabela 22

Alimentos com concentração de agrotóxicos insatisfatória (\%)

\begin{tabular}{l|c|c|c|c}
\hline \multirow{2}{*}{ Produto } & NA & >LMR & >LMR e NA & $\begin{array}{c}\text { Total de } \\
\text { Insatisfatóri }\end{array}$ \\
\cline { 2 - 5 } & $\mathbf{( 1 )}$ & $\mathbf{( 2 )}$ & $\mathbf{( 3 )}$ & $\mathbf{( 1 + 2 + 3 )}$ \\
\hline Abacaxi* $^{*}$ & 39 & 1 & 1 & 41 \\
Alface $_{\text {Cenoura* }}$ & 41 & 0,7 & 1,5 & 43 \\
Feijão & 33 & 0 & 0 & 33 \\
Laranja* $^{*}$ & 6 & 0 & 0 & 6 \\
Maçã & 26 & 1 & 1 & 28 \\
Mamão $^{*}$ & 7 & 1 & 0 & 8 \\
Morango* $^{*}$ & 10 & 7,3 & 2,1 & 20 \\
Pepino* $^{*}$ & 38 & 6 & 15 & 59 \\
Pimentão & 84 & 2 & 2 & 42 \\
Tomate & 9 & 0,9 & 4,7 & 90 \\
\hline Fonte: ANVISA & 2013 & 0 & 2,6 & 12 \\
\hline
\end{tabular}

Fonte: ANVISA, 2013.

1- agrotóxicos não autorizados, 2 -agrotóxicos autorizados mas acima do limite máximo de resíduo e 3 - agrotóxicos não autorizados e autorizados mas acima do limite máximo de resíduo.

*Dados referentes a 2012.

São os estabelecimentos comerciais especializadas em produtos agropecuários os principais responsáveis pela indicação da "assistência técnica" aos agricultores. No município existem duas redes de estabelecimentos comerciais do setor agropecuário, constituídas por 7 lojas, das quais duas estão localizadas na sede e cinco em localidades do interior do município. As inovações físico-químicas são recomendadas por esses estabelecimentos comerciais e nem sempre são confiáveis. Dessa forma, os agricultores encontram-se fortemente subordinados ao comércio desde a fase de aquisição da maioria das inovações técnicas.

Por fim, as inovações biológicas na agricultura afetam diretamente a velocidade da rotação do capital, pois interferem no tempo de produção. Tais inovações, por meio do melhoramento genético das espécies, exercem um certo controle da natureza e possibilitam não somente acelerar o tempo de produção, mas também elevar a produtividade na agricultura. São, portanto, as inovações que mais afetaram o ciclo produtivo, tornando-o mais curto e reduzindo os tempos de não trabalho, ou seja, quando o capital espera a natureza atuar (germinar, crescer, amadurecer etc.).

Ao reduzirem o tempo de produção na agricultura, as inovações biológicas aceleraram a velocidade de rotação do capital e permitiram um certo controle sobre a natureza, mas sem dominá-la plenamente. Apesar de todos os avanços 
decorrentes das inovações biológicas, o ciclo produtivo permanece contínuo e sequencial e, por isso, a natureza, parcialmente dominada, ainda se antepõe ao capital que circula mais lentamente na agricultura, quando comparado à indústria.

$\mathrm{Na}$ produção das inovações biológicas, verifica-se também uma certa dependência da natureza, pois

\begin{abstract}
As inovações vegetais (cultivares vegetais) diferentemente das inovações industriais (que podem ser difundidas de seu lugar de origem para mercados distantes por meio dos mecanismos de comercialização), devem adaptarse às condições edafoclimáticas e ecológicas nas quais serão introduzidas. Portanto, trata-se de um tipo de inovação que não pode ser transferida de seu país de origem para o resto do mundo sem modificações e adaptações subsequentes (WILKINSON; CASTELLI, 2000, p. 54).
\end{abstract}

A necessidade das adaptações encarece o desenvolvimento das inovações biológicas e no caso das hortaliças esse custo torna-se ainda maior devido a diversidade de espécies existentes, as quais ainda se subdividem em inúmeras variedades. Constata-se que as transnacionais do setor adquirem, em vários países, empresas de sementes que possuem os germoplasmas locais e, assim, é possível realizar as adaptações requeridas pela natureza (WILKINSON; CASTELLI, 2000).

Apesar dos custos elevados na produção das inovações biológicas, por uma questão de escala e de investimentos necessários, para os agricultores familiares essas inovações são mais fáceis de serem incorporadas que as mecânicas. Santa Maria de Jetibá não foge à regra e as inovações biológicas são bastante utilizadas na produção agrícola. Na produção de hortaliças utiliza-se prioritariamente sementes híbridas e mudas melhoradas geneticamente, pois esses insumos têm maior produtividade. São usadas sementes de diferentes empresas marcas (Sakata, Top Seeds, Seminis, Syngenta, Hortec e Feltrin) e os agricultores não demonstraram preferência por alguma específica.

No setor de sementes as multinacionais são predominantes. A Monsanto que sempre atuou no setor de commodity, hoje domina o mercado de sementes tanto na produção quanto na comercialização e, somente a Seminis, uma de suas marcas, é responsável pelo comércio mundial de $85 \%$ das sementes de brócolis e $40 \%$ de tomate (BARROS, 2014). 
As sementes têm preço elevado e em Santa Maria de Jetibá constatou-se que esse insumo representa aproximadamente $20 \%$ do custo de produção das hortaliças. Tomando o tomate como exemplo, 500 sementes da marca Syngenta custavam $\mathrm{R} \$ 165,00$. Por serem híbridas, a cada plantio as sementes têm que ser novamente adquiridas no mercado. Além disso, as sementes híbridas conferem maior produtividade e menor resistência, o que demanda maior utilização de insumos nos cultivos. Trata-se de uma estratégia das empresas do setor, as quais produzem insumos interdependentes, ou seja, uma semente híbrida de tomate só será mais produtiva se for utilizado um conjunto de agroquímicos.

No município, na horticultura convencional, não ocorre a produção de sementes por parte dos agricultores e esse insumo é adquirido no comércio local. No entanto, em algumas culturas as mudas são produzidas pelos próprios agricultores, como chuchu, inhame, gengibre, couve, cebolinha, entre outras. São culturas com menos apelo mercadológico e, dessa forma, a produção de mudas ainda não foi apropriada pelo capital, o que não ocorre com o cultivo de morango.

$\mathrm{Na}$ produção de morango, os agricultores usam mudas melhoradas geneticamente que são provenientes de outros estados, como São Paulo e Minas Gerais, ou importadas do Chile. Como Santa Maria de Jetibá é o maior produtor de morango do Espírito Santo e isoladamente a cultura é uma atividade bastante importante economicamente, o município organiza a compra das mudas para reduzir os preços.

$\mathrm{Na}$ produção de feijão os agricultores usam sementes melhoradas geneticamente, mas é comum reaproveitamento das sementes, uma vez que no Brasil apena $18 \%$ das sementes dessa cultura são compradas (NERY; NERY; GOMES, 2007). No entanto, o mesmo não ocorre com o cultivo de milho, no qual quase todas as sementes são compradas. Nos cultivos de café e eucalipto as mudas usadas também são melhoradas geneticamente e todos esses insumos são adquiridos localmente.

\subsection{Infraestrutura do espaço rural e das propriedades agrícolas}

As estradas são uma condição geral de produção fundamental para muitas atividades econômicas. No caso de Santa Maria de Jetibá o caráter fundamental das 
estradas assume relevância ainda maior, pois na produção agrícola do município predominam cultivos temporários e com perecibilidade rápida. É necessário, então, que a produção seja transportada rapidamente para não acarretar perdas ou afetar a qualidade dos produtos.

Existem três estradas estaduais que dão acesso ao município: a ES 355 que corta o município, interligando sua sede a oeste com Santa Leopoldina e ao norte com a ES 261; a ES 263 que interliga a sede municipal à Afonso Claudio; a ES 368 que interliga a sede municipal à Domingos Martins (Figura 19). As duas primeiras estradas estaduais são pavimentadas e a terceira não.

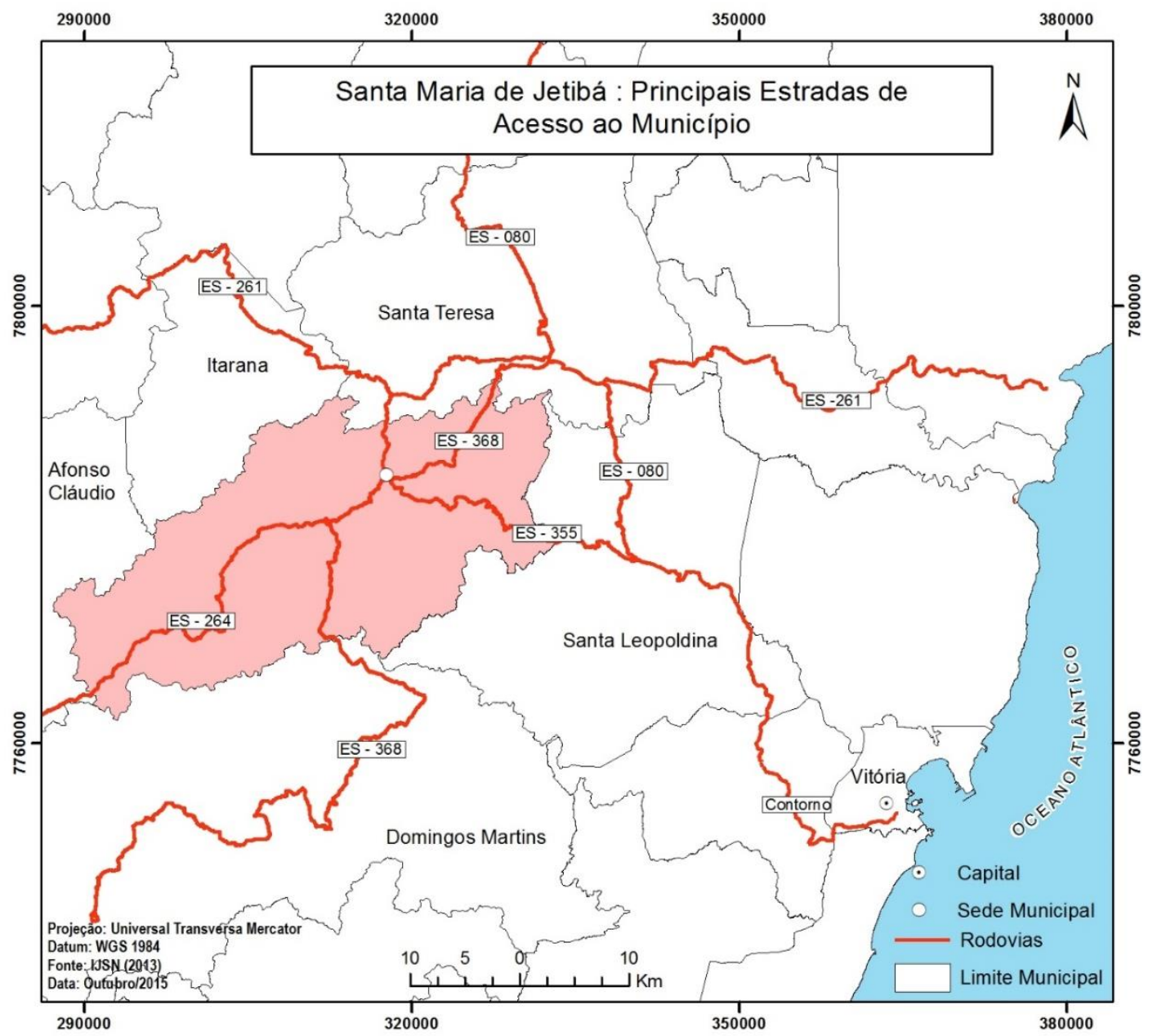

Figura 19- Santa Maria de Jetibá: principais estradas de acesso ao município

Além das estradas estaduais, o município dispõe das estradas rurais que que servem para o deslocamento da população e para o transporte da produção. Segundo estimativas do governo municipal, o número de propriedades rurais em Santa Maria de Jetibá, é o dobro do apontado pelo Censo Agropecuário (4.230). 
Como essas propriedades são predominantes pequenas, para atender aos agricultores há uma densa rede de estradas rurais.

Com essa estrutura fundiária, o espaço rural do município não é marcado pelo isolamento e pelas grandes distâncias entre as propriedades (Figura 20). Pelo contrário, percorrendo curtas distâncias identifica-se várias propriedades com casas relativamente próximas, considerando a típica dispersão do espaço rural.

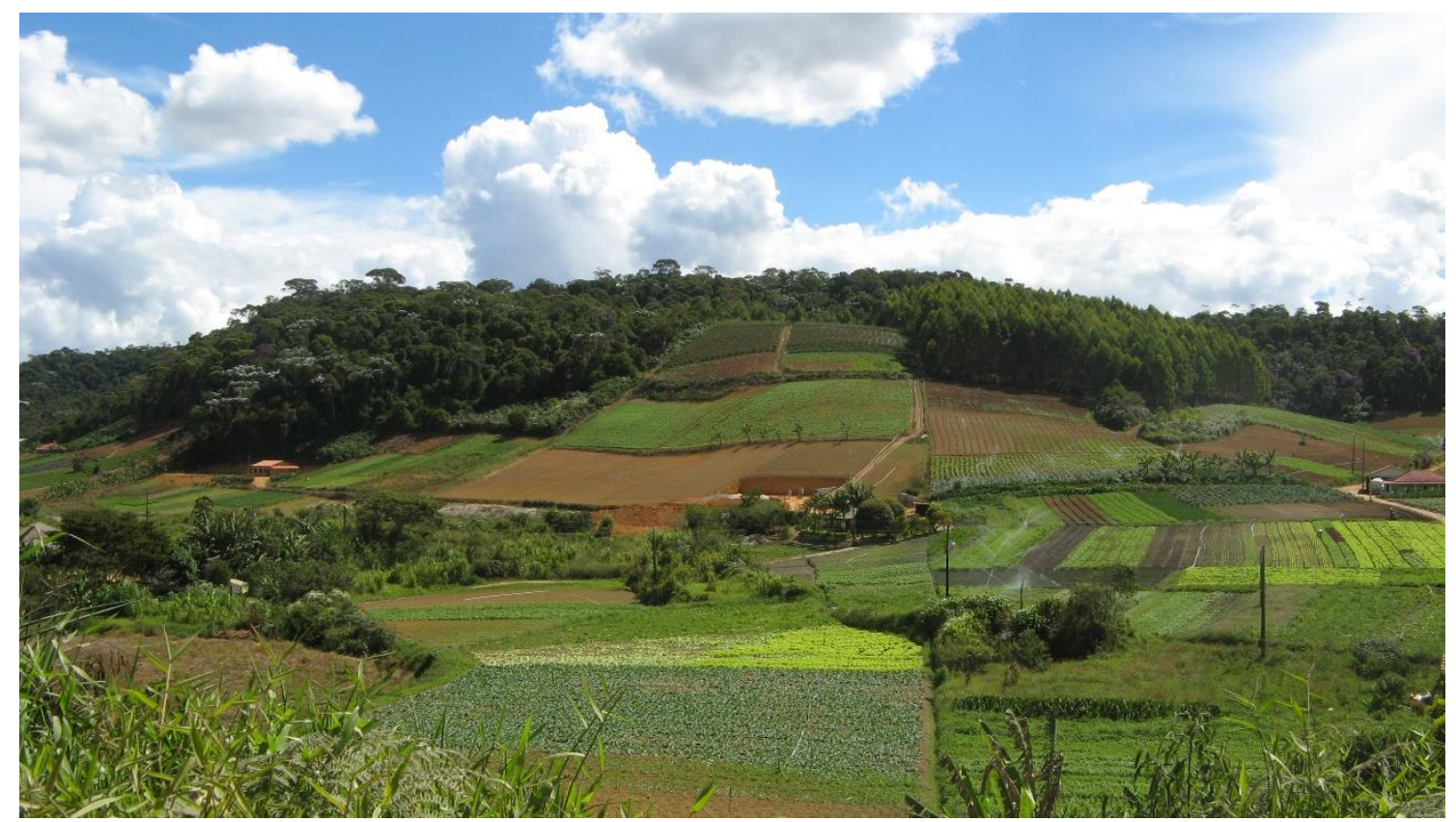

Figura 20 - Paisagem rural: revela a existência de pequenas propriedades e um rural povoado. É possível identificar algumas casas que mostram uma certa proximidade entre as sedes das propriedades.

As estradas rurais são estreitas e não pavimentadas, mas são mantidas em condições adequadas para a circulação de veículos, inclusive para os caminhões que transportam a produção agrícola. O governo municipal, por meio da Secretaria de Interior, executa os serviços de manutenção periodicamente, realizando o patrolamento e o cascalhamento e construindo bueiros e pontes de madeira.

Manter as estradas rurais em condições adequadas é uma das condições fundamentais para o bom desempenho da produção agrícola, uma vez que a frequência das vendas é elevada em Santa Maria de Jetibá. Os produtores de hortaliças fazem entregas até três vezes por semana.

No que concerne às edificações existentes nas propriedades e usadas no processo produtivo agrícola, verifica-se que são precárias, rudimentares e simples. 
Após a colheita, o preparo dos maços de hortaliças (temperos, folhosas e alguns tubérculos) ou a seleção e o embalamento do morango, ocorrem em locais improvisados embaixo das casas, quando estas têm dois pavimentos (Figuras $21 \mathrm{e}$ 22). Hortaliças que precisam ser lavadas, como os tubérculos, são vendidas sujas ou lavadas em caixas improvisadas nas propriedades (Figura 23).

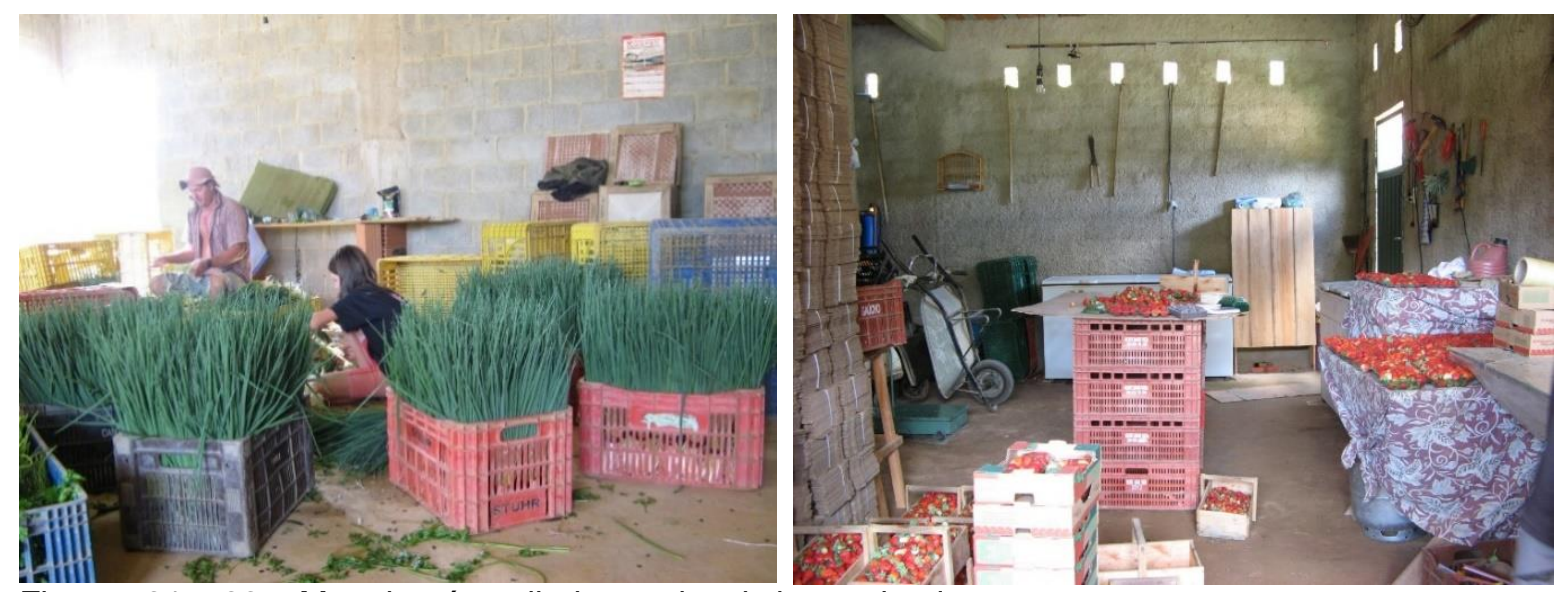

Figuras 21 e 22 - Manejo pós-colheita em locais improvisados.

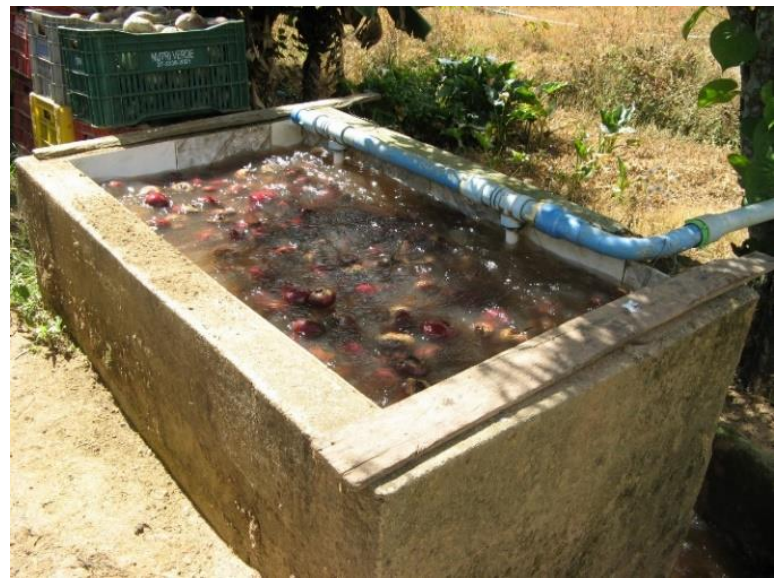

Figura 23- Caixa de concreto para lavagem de tubérculos

\subsection{Expansão do mercado e persistência da subordinação ao comércio}

Os agricultores incorporaram tecnologias e se submetem a extensas jornadas de trabalho, conferindo a Santa Maria de Jetibá o posto de maior produtor de hortaliças do Espírito Santo. Mesmo que grande parte do trabalho seja manual e algumas atividades demandem muito esforço físico, o gargalo da produção agrícola não se manifesta na esfera produtiva, mas sim na comercialização, quando o capital se apropria do excedente produtivo desses agricultores.

Sobretudo ao redor da produção de hortaliças, constituiu-se uma densa rede de comercialização. Além da produção de hortaliças ser constituída por inúmeros 
cultivos, muitos deles têm perecibilidade elevada e, dessa forma, a venda e o transporte têm que ocorrer de forma célere. Ou se vende no momento exato, ou se perde a produção, o que reduz a capacidade de negociação dos preços.

Nessa densa rede comercialização, os principais tipos de comerciantes identificados foram os seguintes: agricultor comerciante, os tradicionais atravessadores, atacadistas locais.

O primeiro, o agricultor comerciante, é um sujeito social que trabalha em bases familiares produzindo hortaliças, mas por ser proprietário de um caminhão, transporta sua produção e, também, a de agricultores familiares vizinhos, até à CEASA. O agricultor comerciante cobra um percentual em relação às cargas transportadas, que vai além do custo do transporte como forma de se remunerar pela atividade comercial que realiza. Inicia-se nesse momento a apropriação de parte do excedente produtivo, proveniente do trabalho dos agricultores familiares. Entre esses agricultores comerciantes, alguns prosperaram mais e alcançaram outros mercados, para além do estado.

No entanto, esse agricultor comerciante se assemelha ao antigo vendeiro, pois tem vínculos pessoais com os agricultores familiares, o que permite 0 estabelecimento de relações de confiança entre ambos. A confiança é um importante atributo, pois a maioria dos agricultores familiares já viveu a experiência de não receber o pagamento pela produção vendida.

Produzindo junto com a família e se apropriando de parte do excedente produtivo de agricultores familiares, o produtor comerciante começa a prosperar economicamente. Na paisagem rural é comum encontrar casas edificadas mais recentemente, com um bom padrão construtivo e dois pavimentos, dos quais o térreo tem pé direito alto o suficiente para servir de garagem para o caminhão.

O segundo tipo refere aos comerciantes intermediários, tradicionalmente conhecidos como atravessadores e que realizam somente a atividade comercial. Embora normalmente não tenham vínculos pessoais com os agricultores familiares, os atravessadores têm importante atuação no comércio de hortaliças. Apesar de transportarem a produção, tendo como destino principal a CEASA, caso não encontrem compradores, o prejuízo recai sobre os agricultores. Além de subordinados ao comerciante, os agricultores também assumem os riscos da 
comercialização. Trata-se de uma espécie de venda consignada. Para o agricultor, outro aspecto desvantajoso da comercialização, refere a demora no recebimento dos pagamentos, até 90 dias, além da emissão de cheques sem fundos.

Os atacadistas consistem no terceiro tipo de comerciantes. São empresas maiores, formalmente registradas e que atendem principalmente a supermercados de portes diferentes. Dessa forma, há uma certa regularidade na compra de hortaliças e para assegurar a oferta em quantidade suficiente, os atacadistas estabelecem contratos de compra e venda, normalmente verbais com os agricultores. Para o agricultor a relação com o atacadista é mais segura, pois a garantia do pagamento é maior.

Independente da forma de comercialização, o produto do trabalho do agricultor encontra-se intensamente subordinado ao comércio. Enquanto um pé de alface é comercializado nos supermercados da Grande Vitória por um valor entre $\mathrm{R} \$ 1,50$ e $\mathrm{R} \$ 2,00$, o produtor recebe somente $\mathrm{R} \$ 0,20$.

As únicas exceções referem-se a duas cooperativas. A Cooperativa de Agricultores Familiares - CAF, que atende somente as compras governamentais. Os preços pagos pela cooperativa são mais elevados que os dos comerciantes. No entanto, a CAF conta com pouco mais 200 cooperados em Santa Maria de Jetibá e é responsável pela comercialização de menos de $1 \%$ da produção do município. A Cooperativa Agroindustrial de Garrafão, que tanto adquire quanto processa a produção de frutas, sobretudo morango, buscando agregar valor à produção e pagar melhor o produtor. A cooperativa possui aproximadamente 150 cooperados.

\subsection{O surgimento e o desenvolvimento da agricultura orgânica em Santa Maria de Jetibá}

Em meados da década de 1980 foram iniciados os primeiros movimentos para ser desenvolver a agricultura orgânica em Santa Maria de Jetibá, município que no âmbito estadual foi pioneiro na atividade. Passadas quase três décadas do início da atividade, Santa Maria de Jetibá destaca-se como o maior produtor orgânico do Espírito Santo, respondendo por aproximadamente $80 \%$ da produção estadual (SHULTZ, 2013). 
Produção essa que é comercializada predominantemente por meio da venda direta ao consumidor em feiras orgânicas localizadas na Grande Vitória. Como consequência dessa forma de comercialização, sem nenhum agente intermediando a relação agricultor familiar/consumidor, ambos sujeitos sociais são beneficiados. De um lado ganha o agricultor familiar que consegue vender o produto do seu trabalho por um valor mais elevado, ampliando sua renda. De outro lado ganha o consumido que tem acesso a um produto orgânico com preços bem acessíveis, equivalentes ao da agricultura convencional.

Nesse contexto, abordaremos o porquê tanto do surgimento e da expansão da agricultura orgânica em Santa Maria de Jetibá, quanto do estabelecimento de uma forma de comercialização que foge às regras do mercado, na qual o agricultor familiar não se subordinado ao capital.

\subsubsection{Histórico da agricultura orgânica em Santa Maria de Jetibá}

Devido ao uso intensivo e indiscriminado de agrotóxicos no cultivo de hortaliças em Santa Maria de Jetibá, desde que se passou a utilizar esse insumo os casos de intoxicação dos agricultores sempre foram recorrentes, comprometendo a saúde e a qualidade de vida desses sujeitos sociais. Em uma pesquisa realizada em 2005, na comunidade de Alto Santa Maria com produtores de hortaliças, constatouse que somente $16 \%$ dos agricultores declararam usar equipamento de proteção individual (EPI) completo (JACOBSON, 2009).

Se num período mais recente somente um pequeno percentual agricultores se protege adequadamente, nos anos iniciais da incorporação dos defensivos praticamente não havia nenhuma proteção para manuseio e aplicação desses insumos. Em momentos diferentes, essa postura do agricultor sempre contribuiu para aumentar ainda mais as possibilidades de intoxicação e danos à sua saúde.

Perante a manifestação de uma série de problemas, em nível nacional muitas críticas já estavam sendo atribuídas ao processo de modernização da agricultura brasileira. Em oposição aos benefícios econômicos relacionados, sobretudo o aumento da produtividade agrícola, eram debatidos os graves prejuízos ambientais e sociais da modernização. Sendo assim, sobre a modernização da agricultura verifica-se que 
As primeiras críticas brasileiras foram tecidas por intelectuais - que através de suas publicações passaram a denunciar os impactos da agricultura moderna - e por categorias profissionais, especialmente os engenheiros agrônomos que contribuíram significativamente na luta contra os agrotóxicos e para o avanço do debate da agricultura alternativa no país (LUZZI, 2007, p. 14).

No âmbito das críticas atribuídas à modernização da agricultura brasileira, era necessário que essas informações chegassem até o agricultor. À medida que o agricultor obtivesse informações sobre as consequências do uso de agrotóxicos e das possibilidades do desenvolvimento de um sistema de produção agrícola alternativo ao modelo convencional e assentado em bases sustentáveis, poderia escolher conscientemente qual modelo seguir.

Como consequência do desenvolvimento de uma "agricultura moderna" que preconiza o uso intensivo de insumos industriais, em Santa Maria de Jetibá muitos agricultores familiares apresentavam problemas de saúde, além da contaminação dos alimentos e dos recursos naturais. Dessa forma, agricultores familiares "Com apoio da Igreja Luterana, Movimento Sindical e ONG's, iniciavam a discussão para a produção de alimentos num processo que se chamava agricultura alternativa" (STANGE, 2007, p.2).

$\mathrm{Na}$ década de 1980 a Igreja Luterana contou com um grupo de pastores que formaram uma pastoral, a Zero 1, inspirada nos preceitos da teologia da libertação (DROOGERS, 2008). A atuação desse grupo contribuiu para promover mudanças importantes nos rumos políticos, econômicos e sociais de Santa Maria de Jetibá. Segundo esses pastores a igreja "deveria esforçar-se ao máximo para promover uma sociedade justa, começando no contexto direto da paróquia" (DROOGERS, p.32, 2008). Seguindo esses preceitos é que a Igreja Luterana fomentou e participou do início dos debates sobre as consequências do uso de agrotóxicos na produção de hortaliças em Santa Maria de Jetibá.

Dessas discussões iniciais surgiu a demanda por orientações de alternativas técnicas para se produzir sem agrotóxico. Por intermédio da Secretaria Estadual de Agricultura - SEAG, a ONG Projeto Tecnologias Alternativas/Federação de Órgãos de Assistência Social e Educacional (PTA/FASE ${ }^{16}$ ) foi contratada para ministrar os

16 Em 1961 foi criada a FASE e 1983 foi iniciado o desenvolvimento do Projeto Tecnologias Alternativas com a FASE, o PTA/FASE, que recebeu recursos financeiros do governo francês para desenvolver pesquisas sobre tecnologias alternativas e repassá-las para os agricultores. 
cursos sobre tecnologias alternativas na agricultura. Pioneira no desenvolvimento de pesquisas em tecnologias alternativas na agricultura brasileira, a PTA/FASE era uma referência no assunto naquele momento. No entanto, nessa época as pesquisas e informações sobre tecnologias alternativas eram incipientes no país.

Os cursos foram realizados em 1986 em várias comunidades rurais de Santa Maria de Jetibá. Esses cursos primeiramente informavam sobre os impactos negativos das tecnologias da modernização da agricultura, com destaque para os agrotóxicos intensamente utilizados nos cultivos de hortaliças. O objetivo era de sensibilizar o agricultor familiar em relação aos malefícios decorrentes da Revolução Verde.

Num segundo momento os cursos apresentavam tecnologias alternativas para o cultivo de hortaliças, atividade desenvolvida pela maioria dos agricultores familiares de Santa Maria de Jetibá. Embora as pesquisas em tecnologias alternativas fossem incipientes, a horticultura era a atividade agrícola com maior número de experiências documentadas (LUZZI, 2007). Esses dois fatores ajudam a entender a explicar a introdução e a expansão da agricultura orgânica em Santa Maria de Jetibá.

Após assistirem às palestras do projeto em questão, um pequeno grupo de agricultores familiares optou por desenvolver a agricultura alternativa em 1986. Eram agricultores familiares que produziam hortaliças utilizando intensivamente o pacote de agroquímicos e, portanto, estavam diretamente expostos à contaminação pelo uso de agrotóxicos. O reconhecimento dos riscos da utilização desses insumos e o comprometimento da saúde de alguns agricultores foi fundamental para a mudança do modelo produtivo.

Esses agricultores receberam assistência técnica do projeto e iniciaram as primeiras experiências com cultivos de hortaliças, como tomate, batata, cenoura e folhosas. Tratavam-se realmente de experiências em busca de alternativas técnicas para alcançar uma produção agrícola sustentável, sem comprometer a qualidade ambiental e a saúde humana, mas viável economicamente para assegurar o bemestar da família.

Essas experiências alternativas ao modelo convencional resultaram da utilização de um conjunto de "técnicas e métodos diferenciados dos pacotes 
convencionais, normalmente estabelecidas de acordo e em função de regulamentos e regras que orientam a produção e impõem limites ao uso de certos tipos de insumos e a liberdade para o uso de outros" (CAPORAL; COSTABEBER, 2004, p.9). Atualmente são reconhecidas por várias denominações, como ecológica, biodinâmica, natural, entre outras, mas neste trabalho optou-se por agricultura orgânica. Tal opção deve-se ao fato dos agricultores de Santa Maria de Jetibá que se dedicam à atividade assim identificarem sua produção e também se inserirem nas políticas governamentais destinadas à agricultura orgânica, atendendo às suas exigências. Para esse modelo de agricultura adotamos a mesma definição da Lei Federal $n^{0}$ 10.831/2003, na qual

Considera-se sistema orgânico de produção agropecuária todo aquele em que se adotam técnicas específicas, mediante a otimização do uso dos recursos naturais e socioeconômicos disponíveis e o respeito à integridade cultural das comunidades rurais, tendo por objetivo a sustentabilidade econômica e ecológica, a maximização dos benefícios sociais, a minimização da dependência de energia não-renovável, empregando, sempre que possível, métodos culturais, biológicos e mecânicos, em contraposição ao uso de materiais sintéticos, a eliminação do uso de organismos geneticamente modificados e radiações ionizantes, em qualquer fase do processo de produção, processamento, armazenamento, distribuição e comercialização, e a proteção do meio ambiente (BRASIL, 2003).

Ao optarem pela produção orgânica, esses agricultores familiares encontravam dois grandes desafios a serem perseguidos: produzir e comercializar. Primeiramente produzir porque apesar de algumas semelhanças com a agricultura pré-industrial, "a agricultura orgânica tecnologicamente não tem nada de primitiva. Suas práticas são repletas de pesquisa científica no intuito de aprimorar as técnicas utilizadas com o objetivo de aumentar eficiência e qualidade na produção" (PIMENTEL, 2005, p. 29 e 30). Nessa perspectiva não se pode confundir agricultura orgânica com a um sistema de produção que

\begin{abstract}
não utiliza agrotóxicos ou fertilizantes químicos de síntese em seu processo produtivo. No limite, uma agricultura com esta característica pode corresponder a uma agricultura pobre, desprotegida, cujos agricultores não têm ou não tiveram acesso aos insumos modernos por impossibilidade econômica, por falta de informação ou por ausência de políticas públicas adequadas para este fim. (CAPORAL; COSTABEBER, 2004, p.9).
\end{abstract}

Nesse momento inicial os agricultores que optaram pela agricultura orgânica, encontraram muitas dificuldades para produzir e assegurar a sobrevivência da família, uma vez que essas "práticas repletas de pesquisa científica" ainda estavam 
em fase inicial e eram pouco conhecidas pelos agricultores. No entanto, mesmo com todas as dificuldades, segundo uma agricultora pioneira na produção de orgânicos "era melhor morrer de fome do que intoxicada com agrotóxico".

Acrescente-se também que essa mudança de modelo produtivo, conhecida como transição agroecológica, no presente ainda é um processo que "adquire enorme complexidade, tanto tecnológica como metodológica e organizacional, dependendo dos objetivos e das metas que se estabeleçam, assim como do "nível" de sustentabilidade que se deseja alcançar" (CAPORAL; COSTABEBER, 2004, p.14).

Dessa forma, naquele momento inicial da produção orgânica, realizar tal transição era um processo muito mais complexo ainda. No entanto, por meio das orientações técnicas e da troca de experiências entre os agricultores, conseguiu-se produzir de forma que os desafios iniciais da produção foram ultrapassados, mas os da comercialização não. Principia-se, então, uma longa trajetória permeada por experiências diversificadas até se conquistar efetivamente o mercado, a certificação e a confiança dos consumidores sobre a qualidade de seus produtos e obter retorno financeiro.

As primeiras colheitas começaram a ser comercializadas ainda em 1986 na forma de cestas entregues semanalmente no município de Vitória. Foi organizado um grupo de naturalistas que consumia aproximadamente 20 cestas semanais. $O$ custo de produção era muito elevado e consequentemente o preço das cestas de hortaliças era caro. Ressalta-se que nessa época não havia nenhuma política específica para a agricultura familiar que pudesse amparar esses agricultores.

Orientados pela ONG e pela Igreja, os agricultores desenvolveram uma experiência de comercialização entre 1987 e 1988 para a população de renda menor, residente em bairros de classe baixa do município de Vitória. Havia o interesse em levar a produção livre de agrotóxicos para essa parcela da sociedade. No entanto, a experiência não resistiu às dificuldades de concorrer com os preços menores e mais competitivos da agricultura convencional.

Em 1988 esses agricultores conquistaram um novo espaço de comercialização na Centrais de Abastecimento do Espírito Santo (CEASA/ES), onde 
foi concedida a parte de um boxe destinado a comercialização dos produtos da agricultura orgânica de Santa Maria de Jetibá.

No final dos anos 1980, com apoio da PTA/FASE e do Projeto Guandu, os produtores de Santa Maria de Jetibá abriram uma loja no hortomercado de Vitória. Essa experiência de comercialização não foi viável devido a problemas de gestão. É importante considerar que se tratavam de agricultores familiares que além de mudarem a forma de produzir estavam desenvolvendo uma atividade nova: a comercialização por meio da venda direta ao consumidor. Em 1989 a loja do hortomercado foi fechada e a comercialização da agricultura alternativa transferida para o galpão da SEAG, mas os problemas na gestão da comercialização permaneceram.

Embora essas experiências de comercialização não tenham culminado em bons resultados financeiros, o fundamental é que contribuíram tanto para aprimorar a produção quanto para a construir uma forma de comercialização dos produtos orgânicos que não dependesse dos atravessadores.

Diante das dificuldades de produção e comercialização, em 1989 foi fundada a Associação de Produtores Santamariense em Defesa da Vida, APSAD-VIDA, primeira associação de agricultores orgânicos de Santa Maria de Jetibá. Foi então elaborado projeto pela APSAD-VIDA para captação de recursos da Alemanha com o objetivo de estruturar a produção e a comercialização de alimentos orgânicos.

Uma instituição alemã, a Associação Evangélica de Cooperação e Desenvolvimento-EZE ${ }^{17}$, financiou o projeto e os recursos foram repassados para a APSAD-VIDA. Em 1992 os recursos foram utilizados para a aquisição de um caminhão para transportar a produção, um dos gargalos da agricultura orgânica naquele momento, uma vez que os agricultores não dispunham de veículos para transportar sua produção. Também foram adquiridos caixotes para armazenar e transportar a produção e efetuado o pagamento por dois anos de um profissional que ofereceu assistência técnica em agricultura orgânica e auxiliou na organização da comercialização.

\footnotetext{
${ }^{17}$ Os recursos da EZE, em sua maioria, são provenientes do Ministério do Exterior da Alemanha e são aplicados principalmente em países subdesenvolvidos.
} 
Finalmente, a partir dos anos 1990, esses agricultores começam a ganhar espaço para comercializar a produção nas feiras livres da Grande Vitória, especificamente nos municípios de Serra e Vitória. Por intermédio da SEAG, da CEASA e da administração pública dos municípios em questão, foram criadas feiras livres específicas para a produção orgânica ou espaços em feiras para a comercializados desses produtos.

Primeiramente, no município de Vitória, foi organizada em 1992 uma feira livre no parque urbano Tancredo Neves, voltada para agricultores e não para comerciantes, onde se praticava a venda direta do produtor para o consumidor. Não era exclusiva para produtos orgânicos, mas esta feira se diferenciava por ser destinada a agricultores. Em 1994, três barracas da tradicional feira livre de Jardim da Penha, foram destinadas a produtores orgânicos.

Em segundo lugar, no município de Serra, no bairro Laranjeiras, foi criada em 1995 uma feira livre exclusiva para produtos da agricultura orgânica com sete barracas. Mas em 1999 a área usada pela feira foi ocupada por um empreendimento imobiliário e os feirantes foram transferidos para uma feira livre do mesmo bairro. Essas foram as primeiras experiências que trouxeram resultados financeiros um pouco melhores para a agricultura orgânica de Santa Maria de Jetibá, mas a comercialização era o grande gargalo da agricultura orgânica.

Em 1994 foi criado um programa municipal específico para agricultura orgânica e que contribuiu para dar continuidade à atividade no município. Ao término da assistência técnica financiada com recursos da EZE, a prefeitura deu continuidade à prestação desse serviço contratando um técnico, além de oferecer alguns insumos como sementes, mudas e composto orgânico.

Em 1996 mais uma associação de agricultores orgânicos foi criada em Santa Maria de Jetibá, a Amparo Familiar, um indicativo de expansão da agricultura orgânica. Com recursos do PRONAF, associação adquiriu um caminhão para transportar a produção de alimentos orgânicos para as feiras. O PRONAF, ao oferecer crédito subsidiado para a agricultura familiar, foi um importante de política agrícola para a expansão da agricultura orgânica no município.

Decorrente do crescimento da produção da agricultura orgânica que ocorreu nos anos 1990, tornou-se necessário identificar formalmente esse produto para 
assegurar a sua qualidade e procedência. Surge, então, a demanda pela certificação da produção orgânica de Santa Maria de Jetibá. No entanto, ainda não havia instrumentos e regras governamentais que respaldassem a agricultura orgânica.

Somente em 1999, após alguns anos de debates e da formação de uma comissão nacional específica para debater e elaborar normas para a produção e certificação orgânica, é que o governo federal publicou a Instrução Normativa (IN) no 7. Essa IN resultou de amplo processo participativo e foi o primeiro instrumento legal a estabelecer normas e procedimentos para a agricultura orgânica e a certificação de seus produtos no Brasil.

Considerando os elevados custos de se recorrer às certificadoras existentes na época e localizadas em outros estados, como a Associação Agricultura Orgânica e o Instituto Biodinâmico,

o Fórum Estadual de Agricultura Familiar, junto a diversos técnicos (as) em agricultura orgânica e outras entidades e agricultores (as), discutiram e criaram 16 de novembro de 1999 a Associação de Certificação de Produtos Orgânicos do Espírito Santo - CHÃO VIVO (MENEGUELI, 2004, p.167).

Localizada em Santa Maria de Jetibá, a Chão Vivo tratava-se de uma entidade sem fins lucrativos e que fornecia os serviços de certificação orgânica para os agricultores familiares com custos menores. A partir de 2000 inicia-se a certificação da agricultura orgânica, o que representou um importante avanço para os agricultores familiares, pois ao assegurar que os seus produtos respeitavam as práticas e normas requeridas para a atividade, contribuiu para aumentar a confiança do consumidor.

Por sua vez, a partir de 2002 inicia-se um processo de ampliação considerável da comercialização da produção de orgânicos, por meio da inauguração de feiras orgânicas maiores (maior número de barracas) nos municípios da Grande Vitória. Somente dezessete anos após o início da produção orgânica, quanto esta já estava certificada, é que os agricultores familiares começaram a conquistar efetivamente melhores condições para a comercialização.

A expansão das feiras orgânicas é um processo que ainda está em curso e ao longo dos anos resultou da ação de um conjunto de entidades e do Estado, tais como: associações de agricultura orgânica, ONG's, certificadora, política do governo estadual e dos municípios da Grande Vitória. Acrescente-se também a expansão do 
mercado consumidor para esses produtos, que certificados se tornaram mais confiáveis e, oportunamente, atraiu mais clientes.

Ao longo desses anos a agricultura orgânica de Santa Maria de Jetibá foi incorporando tecnologias sustentáveis que permitiram aprimorar a produção e aumentar a produtividade, de forma que hoje coloca-se no mercado um produto orgânico de qualidade. Das 88 propriedades certificados pelo Instituto Chão Vivo em 2015, única certificadora de produtos orgânicos do Espírito Santo, 65 estão localizados em Santa Maria de Jetibá.

Embora sejam 65 propriedades certificadas é importante destacar que as vezes mais de uma família produz em uma única propriedade. À medida que os filhos vão se casando e permanecem na agricultura, ocorre uma fragmentação informal da propriedade e uma parte de sua área é destinada para atender à nova família que se constituiu. Considerando que a certificação é da propriedade rural, existem bem mais que 65 famílias trabalhando com a produção orgânica no município.

Além dos avanços produtivos, esse agricultor que também é um feirante, desenvolveu uma boa estrutura de gestão da propriedade, com planejamento adequado dos cultivos, controlando os períodos de plantios e a quantidade a ser plantada, para que a cada semana seja possível realizar colheitas que atendam as demandas de consumo das. São agricultores familiares que produzem para 0 mercado, mas por praticarem a venda direta ao consumidor, os produtos orgânicos têm preços mais acessíveis.

Para Lamarche (1997) a agricultura familiar apresenta extraordinária capacidade de adaptação aos diferentes contextos socioeconômicos em que está inserida. Capacidade essa que facilmente se percebe nos agricultores familiares orgânicos de Santa Maria de Jetibá. Primeiramente, a maioria desses agricultores substituiu os cultivos de café pela horticultura e incorporou os recursos técnicos da modernização da agricultura; depois refutaram o modelo convencional, passaram a incorporar tecnologias sustentáveis e tornaram-se agricultores orgânicos; por fim, além de cultivarem, passaram a desempenhar outra função: feirante. 


\subsubsection{O processo de trabalho da agricultura orgânica}

$\mathrm{Na}$ agricultura orgânica e convencional de Santa Maria de Jetibá tanto as relações de trabalho quando a dimensão física das propriedades rurais são similares. Ambos sistemas produtivos são essencialmente estruturados em pequenas propriedades e no trabalho familiar. Dessa forma, a maioria dos agricultores não manifesta interesse da em aumentar a área das propriedades, pois a terra é de trabalho e a força de trabalho da família seria insuficiente. Também quase não há interesse em contratar mão de obra assalariada, de forma que os agricultores recorrem muito pouco a essa relação de trabalho. Além da dificuldade em encontrar trabalhadores disponíveis, os agricultores consideram elevado o valor de uma diária de trabalho que é de 8h, enquanto eles, que são proprietários, trabalham muito mais.

Apesar das semelhanças mencionadas, a produção orgânica se diferencia da convencional em vários aspectos. Embora a jornada de trabalho seja muito extensa, para os agricultores em sistema orgânico de produção o trabalho tem uma dimensão muito ampla e representa "tudo na vida", "uma benção de Deus", "um prazer". É em torno da centralidade do trabalho que a vida desses agricultores está estruturada.

Ao optarem pela agricultura orgânica os agricultores passaram a ter uma jornada maior que a anterior, quando produziam de forma convencional, devido a algumas particularidades da forma como se desenvolve a atividade em Santa Maria de Jetibá, tais como: as restrições de uso de vários insumos que reduzem o tempo de trabalho na produção orgânica, fazem com que a atividade demande mais mão de obra que a agricultura convencional; após a colheita todos os produtos são preparados para a venda direta ao consumidor nas feiras e, por fim, os agricultores orgânicos despendem muito tempo participando das feira semanais.

Apesar da extensa jornada, trabalham com mais prazer, pois a produção orgânica não promoveu somente benefícios na saúde do agricultor e no meio ambiente e ampliou a renda familiar, mas também contribuiu para ampliar o conhecimento dos agricultores e trouxe reconhecimento do trabalho que realizam.

Nos anos iniciais da transição agroecológica, os agricultores optaram por produzir sem o uso de agrotóxicos exclusivamente por uma questão de saúde. No entanto, depois de estruturada a produção e a comercialização, mais recentemente 
novos agricultores têm optado pela produção orgânica em decorrência também dos maiores rendimentos auferidos pela atividade.

A área produtiva das propriedades com agricultura orgânica varia entre 2 e 3 ha e é ocupada simultaneamente com uma grande variedade de culturas, entre $20 \mathrm{e}$ 40 cultivares diferentes, principalmente hortaliças. São micro cultivos de cada variedade. Como a maioria dos agricultores orgânicos comercializa a produção em feiras, busca-se cultivar muitas variedades e organizar o período e a quantidade de cada plantio para oferecer mais opções aos consumidores e assegurar uma certa regularidade da oferta, ampliando as vendas.

Nessa perspectiva, as propriedades com cultivos orgânicos são muito mais diversificadas produtivamente que as convencionais. Diversificação essa que contribui para o equilíbrio ecológico da propriedade e reduz a manifestação de pragas e doenças. Quando se observa a paisagem, pela diversidade de culturas, facilmente se distingue uma propriedade com produção orgânica das demais.

Outra consequência da diversificação manifesta-se na produção direta dos meios de vida. Se na produção convencional praticamente todos os alimentos são adquiridos no mercado, na agricultura orgânica aproximadamente $50 \%$ são produzidos na propriedade, o que reduz não só o custo de reprodução da família, mas também assegura uma alimentação mais saudável.

Acerca dos meios de produção, a agricultura orgânica incorpora um conjunto de inovações técnicas que são permitidas ou liberadas para a atividade. Primeiramente, as inovações mecânicas usadas na agricultura orgânica são similares às da produção convencional. Todos agricultores orgânicos usam sistemas de irrigação pois suas propriedades possuem eletrificação rural; a maioria possui microtratores e motocultivadores que são usados na preparação dos solos, mas as demais atividades, como a semeadura, plantio, limpeza, poda, pulverização, colheita, entre outras, são realizadas manualmente.

Como a produção é comercializada pelos próprios agricultores, para o manejo pós-colheita as propriedades dispõem de pequenos galpões onde os produtos, de acordo com as particularidades de cada um, são limpos ou lavados, secados, amarrados em molhos, embalados e acondicionados em caixas de plástico para, 
então, serem transportados rumo as feiras orgânicas. Todas essas atividades também são manuais.

A maioria dos agricultores orgânicos também possui caminhonetes que são usadas para o transporte da produção até as feiras orgânicas. As duas associações de agricultores orgânicos possuem caminhões fechados para o transporte da produção. No entanto, se no início a aquisição desses veículos pelas associações foi de extrema importância para o transporte da produção orgânica em Santa Maria de Jetibá, a tendência é que, pelo nível de capitalização dos agricultores orgânicos e as facilidades creditícias, cada um tenha seu veículo e não dependa mais do transporte das associações.

Acerca das inovações físico-químicas e biológicas, verifica-se que a agricultura orgânica, dada suas características produtivas, é pouco subordinada à indústria que produz os insumos dessas inovações. Dessa forma, os custos de produção de da agricultura orgânica são inferiores aos da produção convencional. $\mathrm{Na}$ produção orgânica muitos agricultores criam galinhas para postura e oportunamente produzem o próprio adubo de origem orgânica. O resíduo das aves não é descartado, mas se transforma em um insumo produzido sem custos, uma vez que as galinhas e os ovos são comercializados. Quando a produção de esterco da propriedade não é suficiente, adquire-se esse insumo de outras granjas, mas somente daquelas que não são automatizadas.

É importante ressaltar que a produção animal não é certificada, pois utiliza insumos veterinários e alimentos que não são liberados para a agricultura orgânica. O esterco produzido pelas aves é retirado anualmente das granjas e produzida uma compostagem, cujo período para a decomposição da matéria orgânica e descontaminação requer no mínimo 90 dias. No entanto, como não há oferta local de insumos liberados para a agricultura orgânica, a IN n 17, de 18 de junho de 2014, permite a utilização desse esterco, desde que seguidas as exigências para a produção da compostagem.

Como defensivos são usadas as caldas bordalesa (sulfato de cobre e cal virgem), sulfocálcica (cal virgem e enxofre) e de cinza (cal virgem e cinza). Todos esses defensivos usam substâncias químicas liberadas para a agricultura orgânica certificada e as caldas são produzidas pelos próprios agricultores, com custos de produção muito baixos. Além desses defensivos as estufas também são muito 
utilizadas, sobretudo na produção de morango e tomate. Ao isolarem os cultivos de determinadas condições naturais, permitem o maior controle do ambiente e reduzem 0 ataque de pragas e doenças.

Acerca das mudas e sementes, a produção desses insumos pelo agricultor na agricultura orgânica é bem maior que na convencional, no entanto, também se utiliza sementes e mudas convencionais. Como não há produção de sementes orgânicas no país e as poucas existentes são importadas, a IN № 46 de 2011, que proibia a utilização de sementes e mudas que não fossem orgânicas a partir de outubro de 2013, foi modificada pela IN no 17 de 2014. Esta alterou o prazo e definiu que a partir de 2016 cada estado terá autonomia para estabelecer quais espécies e variedades terão que ser obrigatoriamente orgânicas. É uma estratégia para não inviabilizar a agricultura orgânica e ao mesmo tempo considerar as particularidades de cada unidade da federação em relação à oferta de insumos para a atividade.

É importante considerar que se forem instaladas empresas estrangeiras ou nacionais produtoras de sementes orgânicas, os agricultores orgânicos serão subordinados à indústria sementeira da mesma forma que os convencionais. Mesmo produzindo parte das mudas e semente, esses são os insumos que têm o maior peso no custo de produção. A Companhia Nacional de Abastecimento, por meio do Programa de Aquisição de Alimentos - PAA do Ministério do Desenvolvimento Agrário, vem adquirindo sementes crioulas provenientes da agricultura familiar. Adquiridas em chamadas públicas, essas sementes são distribuídas gratuitamente para a agricultura familiar.

No entanto, no Espírito Santo a produção de sementes crioulas de hortaliças não atende nem as necessidades das propriedades e no país a produção de sementes de hortaliças crioulas ainda é pequena. Caso não se resgatem essas sementes em variedade e quantidade suficiente para atender à demanda da agricultura orgânica, o agricultor orgânico corre o risco de tornar-se subordinado à indústria produtora de sementes orgânicas.

Embora não seja um meio de produção, a certificação orgânica é um procedimento que assegura formalmente que determinado produto respeita as normas e práticas da agricultura orgânica. Nessa perspectiva, a certificação assegura que os meios de produção usados estão em conformidade com as exigências requeridas pela agricultura orgânica. 
Todas as propriedades rurais com produção orgânica em Santa Maria de Jetibá são certificadas por auditoria pelo Instituto Chão Vivo. Essas propriedades estão recebendo apoio do Serviço Brasileiro de Apoio às Micro e Pequenas Empresas - SEBRAE, que por meio do programa Sebraetec concede apoio financeiro para a certificação orgânica da agricultura familiar. O Instituto Chão Vivo certifica somente produção e processamento vegetal e os custos da certificação, que tem que ser renovada anualmente, variam entre $R \$ 1350,00$ a $R \$ 1650,00$. O Sebraetec arca com $90 \%$ dos custos da certificação.

\subsubsection{O produto orgânico e suas estratégias de comercialização: o predomínio da venda direta ao consumidor}

No Brasil, verifica-se entre as unidades da federação diferenças na participação dos principais canais de comercialização dos produtos orgânicos. Considerando os cinco estados com mais unidades de comercialização desses produtos, constata-se que em São Paulo e Rio de Janeiro predominam os supermercados enquanto em Santa Catarina, Rio Grande do Sul e Paraná são as feiras e associações (SEBRAE, 2004 apud MAPA, 2007). Mas ao se considerar os dados para o país, a principal forma de comercialização dos produtos orgânicos são os supermercados, responsáveis por $45 \%$ das vendas, em seguida são as feiras livres com 26\% de participação (SCHULTZ, 2007 apud LENOURD; PIOVANO, 2004).

Nos supermercados que comercializam produtos orgânicos, a oferta vai além dos alimentos in natura e se estendem aos industrializados ou beneficiados. Algumas grandes redes de supermercados possuem marcas próprias de alimentos orgânicos industrializados, como a Taeq Orgânico do grupo Pão de Açúcar, a Sentir Bem Orgânico do Walmart e a Viver Orgânico do Carrefour. Além das marcas próprias, outros produtos orgânicos industrializados ou beneficiados também são comercializados como açúcar, derivados do leite, sucos, biscoitos, sopas instantâneas, massas, farinhas, cereais, entre outros.

No entanto não se trata de produtos provenientes de pequenas empresas e tampouco são comercializados em feiras orgânicas de agricultores familiares. São empresas de porte maior, algumas pertencentes a grandes grupos, e nem sempre 
voltadas exclusivamente para a produção de alimentos orgânicos, sendo estes apenas uma linha da marca. Acrescente-se também que os preços desses produtos são sempre superiores aos tradicionais.

Diferente da média nacional, no Espírito Santo a comercialização da produção de alimentos orgânicos apresenta ordem inversa e outras características. Em 2011 a loja do Carrefour fechou e excetuando uma unidade do Walmart localizada na capital, as grandes redes de supermercados não estão presentes no estado. Quem controla o mercado são redes estaduais, as quais não têm marcas próprias e tampouco de produtos orgânicos.

Em relação aos alimentos orgânicos in natura, que são produzidos essencialmente por agricultores familiares, os supermercados além de terem participação insignificante na comercialização desses produtos, oferecem ao consumidor poucas variedades e praticam preços bem elevados quando comparados às feiras orgânicas. Já os produtos orgânicos industrializados, provenientes de empresas de porte médio a grande, são comercializados nos supermercados ou em lojas especializadas. No entanto, considerando a variedade desses produtos no mercado, verifica-se que nos supermercados da Grande Vitória a oferta é pequena e ainda não existem gôndolas específicas para esses alimentos.

$\mathrm{Na}$ Grande Vitória, onde está concentrado o principal mercado consumidor de produtos da agricultura orgânica do Espírito Santo, o lócus principal da comercialização de alimentos in natura são as feiras livres, as quais respondem por aproximadamente $70 \%$ das vendas. Em seguida são as compras governamentais com $20 \%$ de participação e os $10 \%$ restantes dos alimentos orgânicos são comercializados por embaladoras e supermercados (SHULTZ, 2013).

Atualmente existem 8 feiras orgânicas na Grande Vitória, das quais 4 foram criadas recentemente, entre 2012 e 2014, como resultado da ação do governo estadual em fomentar a expansão da agricultura orgânica no Espírito Santo. Essas feiras se localizam predominantemente em bairros de classe média a maioria dos seus feirantes é constituída por agricultores familiares de Santa Maria de Jetibá.

Essas feiras orgânicas são exclusivas para agricultores familiares venderem a produção, não sendo permitida a participação de comerciantes. Há uma parceria entre a SEAG e as prefeituras dos municípios da Grande Vitória para a gestão das 
feiras orgânicas. A SEAG seleciona os feirantes, os quais têm que se adequar aos regulamentos das feiras livres de cada município.

Identifica-se então, uma particularidade da comercialização dos alimentos orgânicos de Santa Maria de Jetibá, que consiste no fato dos feirantes serem os próprios agricultores familiares. Dessa forma, um único sujeito social desempenha simultaneamente duas funções: agricultor familiar e vendedor para o consumidor final. Estabelece-se então uma relação direta entre o agricultor familiar e o consumidor, "reforçando a garantia da qualidade dos produtos. Além disso, o contato com os consumidores proporciona a troca de informações que auxiliam o agricultor no planejamento da sua produção" (SCHULTZ, 2007, p. 107).

Não há então um comerciante intermediando a relação entre o agricultor familiar e o consumidor. Trata-se, portanto, de uma cadeia de comercialização curta, constituída somente por dois elos: produtor e consumidor. Além de estabelecer uma relação de confiança entre o consumidor e o agricultor acerca da qualidade da mercadoria vendida, outra consequência dessa forma de comercialização é a redução dos preços dos alimentos orgânicos, conforme tabela 23.

Outro aspecto importante é que a formação do preço dos alimentos orgânicos não é especulativa. Os preços dos alimentos orgânicos são pouco influenciados pela lei da oferta e da procura e apresentam oscilações insignificantes ao longo do ano. Um bom exemplo para ilustrar essa realidade é o caso do tomate da agricultura convencional no ano 2012, quando seus preços se elevaram consideravelmente e tornou-se um dos vilões do aumento da inflação no Brasil. Na Grande Vitória o quilo do tomate chegou a custar aproximadamente $R \$ 10,00$, enquanto o preço o tomate orgânico comercializado nas feiras-livres permaneceu em $R \$ 4,00$.

Podemos considerar que a principal forma de comercialização dos alimentos orgânicos de Santa Maria de Jetibá é um caso sui generis. Pouco influenciados pela especulação, sem intermediação de um comerciante e utilizando mão de obra familiar, esses produtos têm seu preço formado, sobretudo, pelo custo de produção. Conforme pode ser observado na tabela 23, os alimentos orgânicos nas feiras livres, têm preço menor que os praticados nos supermercados, tanto em relação aos orgânicos quanto aos convencionais. Isso significa que o alimento orgânico da feiralivre é, em média, mais barato que o alimento contaminado do supermercado. 
Tabela 23

Preços dos alimentos orgânicos e convencionais (valores em $\mathbf{R} \$$ )

\begin{tabular}{l|cc|c}
\hline \multirow{2}{*}{\multicolumn{1}{c|}{ Alimentos }} & \multicolumn{2}{|c|}{ Orgânico } & Convencional \\
\cline { 2 - 4 } & Feiras livres & Supermercado & Supermercado \\
\hline Agrião & 1,00 & - & 1,99 \\
Alface americana & 1,00 & - & 1,99 \\
Alface & 1,00 & - & 1,49 \\
Abobrinha (kg) & 2,50 & 7,20 & 1,99 \\
Banana prata (kg) & 3,00 & 4,99 & 3,99 \\
Brócolis japonês & 1,50 & - & 6,00 \\
B̈atata baroa (kg) & 4,00 & - & 4,99 \\
Batata inglesa (kg) & 4,00 & 14,99 & 3,99 \\
Berinjela (kg) & & 9,99 & 2,29 \\
Beterraba (kg) & 2,50 & 9,99 & 2,99 \\
Cenoura (kg) & 2,50 & 7,90 & 1,99 \\
Chuchu (kg) & 2,50 & - & 0,99 \\
Couve (maço) & 1,00 & - & 1,49 \\
Couve-flor (kg) & 3,50 & 10,70 & 4,99 \\
Inhame & 2,50 & 9,99 & 3,99 \\
Jiló (kg) & 4,00 & 7,99 & 3,49 \\
Rabanete & 4,00 & 8,99 & 8,00 \\
Repolho roxo (kg) & 1,50 & 4,80 & 2,49 \\
Rúcula (maço) & 1,00 & - & 1,99 \\
Tomate & 4,00 & 17,04 & 3,50 \\
Vagem & 4,00 & - & 4,99 \\
\hline Fonte: Dados & & & \\
\hline
\end{tabular}

Fonte: Dados coletados em feiras livres da Grande Vitória e nos supermercados Perim e Carone (maiores redes de supermercados da Grande Vitória), entre 13 e 18 de maio de 2013.

A agricultura orgânica tem custos de produção mais elevados que a agricultura convencional, pois demanda mais mão de obra, requer certificação e não é produzida em grande escala, (PIMENTEL, 2005). No entanto, no caso de Santa Maria de Jetibá, a venda direta ao consumidor permite a prática de preços menores que os convencionais e, ao mesmo tempo, assegura uma margem lucro maior para o agricultor familiar.

Organizadas e consolidadas, as feiras livres da Grande Vitória tornaram-se um espaço de referência na comercialização de alimentos orgânicos de Santa Maria de Jetibá e conquistaram um consumidor cativo. Tanto a qualidade quanto os preços praticados são extremamente atrativos nas feiras livres e, por essa razão, outras formas de comercialização de alimentos orgânicos, como os supermercados, conquistam poucos consumidores. Nos supermercados a oferta de alimentos 
orgânicos, tanto em quantidade quanto em variedade, é inferior a de uma única barraca de feira.

Quando a agricultura orgânica de Santa Maria de Jetibá tornou-se certificada e passou a ser comercializada na feira do Barro Vermelho, a primeira feira de orgânicos de proporções maiores e localizada em um bairro de classe média, o alimento orgânico ainda era muito desconhecido e se limitava a uma clientela bastante reduzida.

Como nas feiras orgânicas só existem agricultores familiares que praticam a venda direta ao consumidor, foi e é possível comercializar esses produtos a preços similares aos convencionais. À medida que novas feiras orgânicas foram sendo criadas, os agricultores orgânicos aprimoraram as técnicas de cultivo, produzindo um produto mais atraente ao consumidor, a atividade foi se tornando mais lucrativa, atraindo novos agricultores para atividade. Aumentou também o mercado consumidor, o produto orgânico tornou-se mais conhecido e as feiras continuaram praticando preços atrativos.

Constitui-se um sólido canal de comercialização, tanto que atualmente os supermercados não conseguem concorrer com os preços praticados por meio das vendas diretas nas feiras orgânicas. 


\section{CONSIDERAÇÕES FINAIS}

O início da formação territorial de Santa Maria de Jetibá apresenta características diferentes das que foram predominantes no país. Como parte de uma colônia imperial de imigrantes europeus, nesse território, o acesso à terra na forma de pequenas propriedades foi assegurado ao imigrante para trabalhar com sua família. Constituiu-se nesse território uma estrutura fundiária desconcentrada, sobretudo para a realidade latifundiária brasileira, pois só havia pequenas propriedades na colônia.

Embora a utilização do trabalho escravo não fosse permitida nas colônias imperiais, a maioria dos imigrantes não tinha recursos para adquirir essa mão de obra. Dessa forma, nas colônias sempre se usou trabalhadores livres, constituídos pelos membros da família dos imigrantes.

No Brasil, face a utilização da mão de obra escrava, o trabalho manual degradava e inferiorizava a pessoa que o realizava. Mas o imigrante, além de ser proveniente da Europa, onde não se usava o trabalho cativo do negro, também se instalou em uma colônia que estava distante das regiões escravistas do Espírito Santo. Nas proximidades da colônia de Santa Leopoldina o emprego do trabalho escravo era pontual.

Nessa perspectiva, o imigrante não construiu uma representação negativa do trabalho manual. Pelo contrário, ao ter acesso à propriedade da terra, o imigrante creditava no trabalho a possibilidade de acumular riqueza. Essa representação alcança proporções maiores, pois o imigrante e sua família, agora proprietário de terra e agricultor familiar, entende que trabalha para si próprio e não mais para o capitalista, como foi a situação em sua região de origem. Embora essa relação, que unifica trabalho e propriedade dos meios de produção, obscureça que o agricultor familiar permanece subordinado ao capital, não mais diretamente por meio do trabalho, mas indiretamente por meio da produção.

Imigrantes de procedência de diferentes regiões da Europa se estabeleceram na colônia de Santa Leopoldina, porém entre eles os pomeranos se destacaram pela dedicação ao trabalho e foram até considerados "a pérola da colônia". Além da disciplina exacerbada para o trabalho, os pomeranos e seus descendentes 
ocuparam as áreas de altitude mais elevada da colônia, onde mantiveram certo isolamento físico e cultural. Foram nessas áreas que se constituiu o território que hoje corresponde ao município de Santa Maria de Jetibá.

Durante mais de um século a cafeicultura foi a principal atividade econômica desse território, mas a altitude mais elevada era desfavorável para a cultura, a fertilidade dos solos era baixa e poucas técnicas eram utilizadas, o que resultava em baixos níveis de produtividade. Além disso, a produção foi fortemente subordinada pelo comércio, pois constituiu-se uma cadeia de comercialização formada por vários elos. De um lado havia inúmeros pequenos produtores e do outro uma rede bem estruturada e articulada de comercialização, que capturava grande parte do excedente produtivo.

Apesar de ter sido uma colônia próspera, essa prosperidade não era dos agricultores, mas sim da classe de comerciantes. A sede da colônia, decorrente de sua localização estratégica, tornou-se um importante entreposto comercial, onde se estabeleceram grandes casas comerciais que detinham o monopólio fluvial do transporte. Esse entreposto era a porta de entrada e saída das mercadorias consumidas e produzidas pela colônia.

A colônia foi emancipada e posteriormente elevada à categoria de município, mas a estrutura de comercialização permaneceu a mesma. Somente com o fim do monopólio do transporte é que a sede do município deixa de ser um entreposto comercial e torna-se um local de passagem. Se para as grandes casas comerciais isso significou a falência, para os agricultores familiares nada se alterou e a produção permaneceu subordinada ao comércio.

Nessas circunstâncias produtivas e comerciais, a produção de café não permitia muito mais que a reprodução simples das famílias, que mesmo com tamanha disciplina para o trabalho, viviam em condições que em alguns aspectos se aproximavam do estado de penúria. Por várias décadas esses agricultores familiares seguiram produzindo diretamente grande parte dos meios de vida, além do café como cultura comercial.

Nos anos 1960, as atividades econômicas do território em questão começam a tomar novos rumos. Nessa década, com a implementação da política de erradicação dos cafezais, os cultivos de hortaliças com fins comerciais começam a 
se expandir e até a ocupar o lugar da cafeicultura. Se a altitude mais elevada reduzia a produtividade do café, para a maioria das hortaliças essa é uma condição natural extremamente favorável.

Concomitante à horticultura, foi introduzida também a avicultura de postura com fins comerciais, ambas sem tradição no Espírito Santo, que se destacava como produtor de commodities. Com a introdução da avicultura de postura, o esterco produzido pela atividade foi fundamental para aumentar a produtividade da horticultura ao elevar o nível de fertilidade dos solos. Trata-se de um adubo orgânico com excelentes propriedades fertilizantes para as hortaliças, disponível localmente, com baixo custo e que ainda contribui para a conservação do solo.

Ambas as atividades se expandiam paralelamente e durante algumas décadas atendiam praticamente ao mesmo mercado consumidor, concentrado principalmente na região da Grande Vitória. Nos anos 1970 inicia-se a modernização da agricultura no Espírito Santo, mas o território de Santa Maria de Jetibá já havia se antecipado e incorporado algumas inovações técnicas. A avicultura de postura usava, por exemplo, aves melhoradas geneticamente, sistema de criação baseado no confinamento em gaiolas e rações que combinavam nutrientes. Na horticultura, além do esterco das aves, já se usavam sementes industrializadas.

Além das duas transformações estruturais, erradicação dos cafezais e modernização da agricultura, que expulsaram a população do campo provocando intenso êxodo rural, na década de 1970, no âmbito do II PND, foi iniciada a implantação dos grandes projetos industriais, localizados sobretudo na Grande Vitória. Assim, ocorreu outra transformação estrutural: a industrialização do Espírito Santo.

Nesse contexto, a Grande Vitória tornou-se uma região atrativa de mão de obra, para onde se direcionaram os principais fluxos de migração do campo para a cidade. Como consequência o estado se urbanizou, ampliando o mercado consumidor, com destaque para a região da Grande Vitória que se consolida como o principal mercado consumidor estadual.

No território de Santa Maria de Jetibá essas transformações se manifestam de forma diferente. Após a erradicação do café, a avicultura de postura e os cultivos de hortaliças se expandem e como esta atividade tem capacidade de geração de 
mão de obra muito superior à cafeicultura, a demanda por mão de obra foi ampliada. Face à modernização da agricultura, ambas as atividades vão incorporando tecnologias e se expandindo e acompanhando a ampliação do mercado consumidor, decorrente da urbanização estadual e do crescimento populacional da Grande Vitória.

Apesar das semelhanças iniciais, de algumas transformações estruturais e da melhoria e ampliação da infraestrutura de transportes beneficiarem tanto a avicultura de postura quando a horticultura, tais atividades passam a se diferenciar em vários aspectos tais como: incorporação de inovações, relações de trabalho, dimensão da produção e formas de comercialização.

Face às longas distâncias das principais regiões produtoras das matériasprimas da ração, a avicultura de postura em Santa Maria de Jetibá apresenta condição produtiva bastante desfavorável, pois seus custos produtivos são mais elevados. No entanto, outros aspectos favorecem a atividade, tais como: localização próxima de grandes centros consumidores do estado e do país; condições adequadas de temperatura e qualidade da mão de obra. Além disso, foi estruturada uma cadeia produtiva altamente verticalizada e a atividade tem elevado nível de incorporação técnica.

A avicultura de postura trata-se de uma atividade da agropecuária pouco subordinada à dinâmica da natureza, pois muitos limites naturais impostos à reprodução do capital foram suprimidos pelas inovações técnicas, que são extremamente avançadas.

Tais inovações tornaram a avicultura de postura bastante atrativa para o capital, pois além das aves melhoradas geneticamente tornarem-se cada vez mais produtivas e menos consumidoras de ração, todo o processo produtivo, da cria ao empacotamento dos ovos, foi automatizado. Tanto que a atividade passou a ser denominada de produção industrial de ovos. É exatamente esse o padrão tecnológico predominante na avicultura de postura em Santa Maria de Jetibá, município que tem o maior nível de automação do país.

Nessas condições técnicas, a avicultura de postura, que é disparadamente a principal atividade econômica do município, tem reduzida capacidade de geração de empregos, pois a atividade é determinada por granjas de porte grande. 
Considerando as variações de porte, as granjas apresentam importantes diferenças em relação ao padrão tecnológico, às relações de trabalho e à estruturação da cadeia produtiva.

Como a produção de ovos é realizada predominantemente em granjas de porte grande, cujos proprietários são empresários do setor avícola, a mão de obra empregada é assalariada. Ao contratar essa mão de obra assalariada, os avicultores preferem declaradamente os descendentes de pomeranos, pois os consideram extremamente comprometidos com o trabalho. Mesmo não sendo proprietários dos meios de produção, esses trabalhadores desempenham suas funções como se as granjas Ihes pertencessem, contribuindo para o melhor desempenho da atividade.

Outro aspecto refere-se a forma inovadora como os avicultores de porte grande estruturaram a cadeia produtiva da avicultura. A montante, os avicultores são proprietários das fábricas de ração e negociam coletivamente a aquisição das matérias-primas para produzirem tal insumo. $O$ transporte dessas matérias-primas é feito por caminhões, cujas frotas pertencem aos avicultores. A jusante, os avicultores também dominam o comércio e o transporte da produção. Negociam diretamente com grandes atacadistas e redes de supermercados e fazem a entrega da produção, que é transportada em caminhões, cujas frotas também são de propriedade dos avicultores.

A estruturação de uma cadeia produtiva altamente verticalizada, o elevado nível de incorporação tecnológica, as condições de temperatura favoráveis, a proximidade de grandes centros consumidores, a qualidade da mão de obra e expansão do mercado consumidor, contribuíram diretamente para que a avicultura de postura se tornasse uma atividade competitiva em Santa Maria de Jetibá

Por sua vez, como na produção de hortaliças a atividade ainda é bastante subordinada à dinâmica da natureza e a escala produtiva pequena, a incorporação de inovações técnicas encontra alguns limites. Dessa forma, a atividade incorporou plenamente as inovações biológicas e físico-químicas, que aumentaram a produção e a produtividade e também possibilitaram a introdução de novas variedades de cultivos

No entanto, as inovações mecânicas foram incorporadas parcialmente, pois tanto a acentuada declividade dos terrenos, quanto as características de alguns 
cultivos, impedem o emprego de determinadas máquinas e equipamentos. Acrescente-se também que a produção de hortaliças ocorre predominantemente em pequenas propriedades e assentada no trabalho familiar, dessa forma, naqueles cultivos que permitem a mecanização, o investimento necessário é incompatível com a escala produtiva.

Considerando a escala de produção e os limites impostos pela natureza à incorporação de inovações, a produção de hortaliças em Santa Maria de Jetibá não se apresenta como uma atividade atrativa para o capital. A atividade é, então, realizada por agricultores familiares e é a principal geradora de empregos em Santa Maria de Jetibá.

A montante, esses agricultores estão subordinados aos estabelecimentos comerciais locais, onde adquirem insumos agropecuários. Como a assistência técnica oferecida pelos órgãos públicos é insuficiente para atender à demanda dos agricultores, são esses estabelecimentos que recomendam a utilização de insumos, muitas vezes desnecessária. A jusante, os agricultores estão subordinados a uma complexa rede de comercialização, constituída por diferentes tipos de comerciantes que se apropriam de grande parte do excedente produtivo.

Para compensar o baixo nível de mecanização e também a intensa subordinação da produção ao comércio, esses agricultores se submetem a longas jornadas de trabalho. Aquela valorização do trabalho que diferenciava o imigrante pomerano na colônia, permanece entre os seus descendentes, mas quem se apropria de grande parte do excedente produtivo dos agricultores familiares são os comerciantes. Apesar disso, esses agricultores admitem que a partir da modernização da agricultura houve melhora das condições de vida e ampliação dos rendimentos e nem de longe preferem a vida pretérita.

Para Santa Maria de Jetibá se tornar o maior produtor de hortaliças do Espírito Santo, da mesma forma que na avicultura de postura, algumas condicionantes foram comuns às duas atividades, como a modernização da agricultura, a ampliação do mercado consumidor, melhoria da infraestrutura (energia e estradas), proximidade do mercado consumidor e as condições climáticas. No entanto, especificamente para a produção de hortaliças, a oferta local de esterco e, sobretudo, a exacerbada disciplina para o trabalho foram fundamentais para o crescimento da produtividade. 
Por fim, apesar de não ter peso econômico, o município também é o maior produtor orgânico do estado. A atividade surgiu como reação à agricultura convencional, que devido ao uso intensivo de agroquímicos afetava a saúde do agricultor. Com o apoio de ONG's, Igreja Luterana e de órgãos governamentais, os agricultores orgânicos, primeiramente incorporaram tecnologias permitidas para a atividade, que são de baixo custo, e conseguiram produzir sem os insumos convencionais.

Paralelamente à produção e após várias experiências de comercialização que não foram muito exitosas, a criação de feiras livres exclusivas para a produção orgânica se expande e se consolida como principal canal de comercialização. Localizadas sobretudo na Grande Vitória, as feiras orgânicas são exclusivas para agricultores, onde se pratica a venda diretamente para o consumidor e por isso os preços são muito atrativos, que impossibilitam a concorrência dos supermercados. Nessas condições produtivas e de comercialização, os agricultores orgânicos são muito pouco subordinados ao comércio, o que lhes permite auferir ganhos superiores aos agricultores convencionais. 


\section{REFERÊNCIAS BIBLIOGRÁFICAS}

ABRAMOVAY, Ricardo. Agricultura familiar e serviço público: novos desafios para a extensão rural. Cadernos de Ciência \& Tecnologia, Brasília, v.15, n.1, p.137-157, jan./abr. 1998.

ALMADA, Vilma Pereira. A escravidão na história econômico-social do Espírito Santo 1850-1888. Niteroi, 1981. Dissertação (Mestrado em História) Centro de Estudos Gerais, Universidade Federal Fluminense.

ALMEIDA JUNIOR, Helio Carreço de. Evolução da fragmentação de mata no município de Santa Maria De Jetibá. Vitória, 2006. 56 f. Monografia (Trabalho de Conclusão de Curso em Geografia) - UFES.

ALMEIDA, Vicente Eduardo Soares de; CARNEIRO, Fernando Ferreira; VILELA, Nirlene Junqueira, 2009. Agrotóxicos em hortaliças: segurança alimentar, riscos socioambientais e políticas públicas para promoção da saúde. Tempus - Actas em Saúde Coletiva, vol. 4, n. 4. 2009.

ANVISA. Programa de Análise de Resíduos de Agrotóxicos em Alimentos (PARA). Relatório, 2011/12. Brasília, 2013. Relatório.

APES, 1873. GDG, Segunda Série (383L), Livro 71.

AVES - Associação de Avicultores do Espírito Santo. Perfil da avicultura de postura 2014/2015. Disponível em: http://www.associacoes.org.br/aves/perfil-da-avicultura. Acesso em: 15 mar. 2015.

BARROS, Bettina. Monsanto já domina mercado mundial de sementes de hortaliças. Valor Econômico. 11 set. 2014. Disponível: http://www.valor.com.br/agro/3691102/ monsanto-ja-domina-mercado-mundial-de-sementes-de-hortalicas\#ixzz3ly2CyclA.

BASSANEZI, Maria; SCOTT, Ana; BACELLAR, Carlos; TRUZZI, Oswaldo. Atlas da Imigração Internacional em São Paulo 1850-1850. São Paulo: Editora Unesp, 2008.

BORGES, Ana Lúcia; SOUZA, Luciano da Silva. Análise química do solo, interpretação e recomendações de calagem e adubação numa perspectiva agroecológica. In: TOFANELLI, Mauro Brasil Dias; SILVA, Tácio Oliveira da. (Orgs.). Manejo ecológico e conservação dos solos e da água no Estado de Sergipe. São Cristóvão, SE: Editora UFS, 2011, v. 1, p. 177-203.

BRANDÃO, Antônio Carlos. Território e Desenvolvimento: as múltiplas escalas entre o local e o global. Campinas, SP: Editora da UNICAMP, 2007.

BRASIL. Ministério da Agricultura, Indústria e Commércio. Recenseamento do Brazil

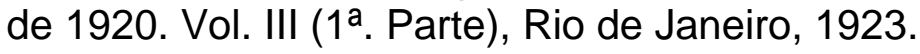


BUFFON, José Antônio. O café e a urbanização no Espírito Santo: aspectos econômicos e demográficos de uma agricultura familiar. Campinas, 1992. 352f. Tese (Doutorado em Economia), Instituto de Economia, Universidade de Campinas.

BUZANELO, Edemar João; CARIO, Silvio Antonio Ferraz. Notas sobre a teoria marxista da renda da terra. Revista de Ciências Humanas. Santa Catarina, UFSC, v. $5, n^{\circ}-8,1986$. (32-47)

CAMPOS JR. Carlos Teixeira de. O novo arrabalde. Vitória: PMV, Secretaria Municipal de Cultura e Turismo, 1996.

. A formação da centralidade de Colatina. Vitória: IHGES, 2004.

CANO, WILSON. Raízes da concentração industrial em são Paulo. Difel: Rio de Janeiro e São Paulo, 1977.

CAPORAL, Francisco Roberto; COSTABEBER, José Antônio. Agroecologia: alguns conceitos e princípios. Brasília: MDA/SAF/DATER-IICA, 2004.

CARNEIRO, Fernando. História da imigração no Brasil: uma interpretação. Boletim Geográfico, Rio de Janeiro: IBGE, v. 6, № 69, P. 1009-1044, dez, 1948.

CARVALHO, Regina Hees. Santa Maria de Jetibá: uma comunidade teuto-capixaba. São Paulo, 1978. Dissertação (Mestrado em História) Faculdade de Filosofia, Letras e Ciências Humanas, Universidade de São Paulo.

CLAVAL, Paul. Território na transição da pós-modernidade. Geographia, Niterói: v.1, n.2, 1999. Disponível em: http://www.uff.br/geographia/ojs/index.php/geographia/ article/view/16. Acesso em 10 abr. 2013.

COLBARI, Antonia. Familismo e Ética do Trabalho: O Legado dos Imigrantes Italianos para a Cultura Brasileira. Rev. bras. Hist., São Paulo, v. 17, n. 34, 1997. Disponível em: <http://www.scielo.br/scielo.php?script=sciarttext\&pid=S0102$01881997000200003 \& \mid n g=e n \& n r m=i s o>$. Acesso em: 12 out. 2014.

COSTA, Emília Viotti da. Da senzala à colônia. São Paulo: Difusão Europeia do Livro, 1966.

COSTA, João Ribas da Costa. Canoeiros do Rio Santa Maria. 2 ed. Espírito Santo: Prefeitura Municipal de Santa Leopoldina e FCAA/UFES. 1982.

COVRE, J. FASSARELLA, R. A. Cadeia produtiva da avicultura de postura: um estudo no município de Santa Maria de Jetibá no Estado do Espírito Santo. In: 48o Congresso Brasileiro de Economia e Sociologia Rural, 2010, Campo Grande. Anais...Campo Grande: UFCG, 2010. Disponível em http://www.sober.org.br/ palestra/15/820.pdf. Acesso em 15/02/2011.

DENATRAN - Departamento Nacional de Trânsito. Frota de veículos. Disponível em: http://www.denatran.gov.br/frota2014.htm. Acesso em: 10 mar. 2015. 
DIAS, Guilherme Leite da Silva; AMARAL, Cicely Moitinho. Mudanças estruturais na agricultura brasileira, 1980-1998. In: BAUMANN, Renato. Brasil: uma década em transição. Rio de Janeiro: Editora Campus, 1999, p. 223-253.

DIETZE, Albert Richard. 1877. Disponível em: http://www.iberoamericadigital.net.

DI FRANCESCO, Ivana Vervloet. História e genealogia: família Vervloet no Brasil, 2005. Disponível em http://www.familiavervloet.com.br.

ELIAS, Denise. Globalização e Agricultura: a região de Ribeirão Preto - SP. São Paulo: EDUSP, 2003.

EMBRAPA - Empresa Brasileira de Pesquisa Agropecuária. Manual de Segurança e Qualidade para Avicultura de Postura. Brasília: EMBRAPA/SEDE, 2004. 97 p. (Qualidade e Segurança dos Alimentos). Projeto PAS Campo. Convênio NI/SENAI/ SEBRAE/EMBRAPA. Disponível em: http://ainfo.cnptia.embrapa.br/digital/bitstream /item/18216/1/manualsegurancaqualidadeaviculturadepostura.pdf. Acesso em: 12 jun. 2013.

Sistema alternativo de criação de galinhas caipiras, 2007. Disponível em: http://sistemasdeproducao.cnptia.embrapa.br/FontesHTML/Ave/SistemaAlternativo CriacaoGalinhaCaipira/index.htm. Acesso em: 10 dez. 2014.

FEITOZA, L. R. ET all). Mapa das Unidades Naturais do Estado do Espírito Santo Informações básicas. In: FEITOZA, L. R.; STOCKING, M. S.; RESENDE, M (eds.). Natural Resources Information Systems for Rural Development - Approaches for Espírito Santo State, Brazil. Vitória, INCAPER, 2001. p. 212-217.

FERRARI, Angela de Biase. Notas sobre os alemães no Espírito Santo. In: II Colóquio de Estudos Teuto-Brasileiros, Recife, abril de 1968.

GRAZIANO DA SILVA, José. Progresso técnico e relações de trabalho na agricultura paulista. Campinas, 1980. Tese (Doutorado em Economia) - Departamento de Economia e Planejamento Econômico do Instituto do Instituto de Filosofia e Ciências Humanas, Universidade Estadual de Campinas.

A nova dinâmica da agricultura brasileira. 2.ed. rev. Campinas, SP: UNICAMP, 1998.

UFRGS, 2003.

Tecnologia e agricultura familiar. 2.ed. Porto Alegre, Editora da

GROSSELLI, Renzo M. Colônias imperiais na terra do café: camponeses trentinos, vênetos e lombardos) nas florestas brasileiras, Espírito Santo, 1874-1900. Vitória: Arquivo Público do Espírito Santo, 2008.

HAESBAERT, Rogério. Des-territorialização e indentidade: a rede "gaúcha" no Nordeste. Niterói, EDUFF, 1997. 
HEINEMANN, José Carlos. Bons soldados e excelentes agricultores. Revista do Instituto Humanistas Unisinos, São Leopoldo/RS, edição 271, p. 5-8, 01 de set. 2008. Entrevista concedida a Patrícia Fachin.

HOFFMANN, R. A estrutura Fundiária no Brasil de acordo com o Cadastro do INCRA: 1967 a 1998. Convênio INCRA/UNICAMP, 1998. Disponível em http://www.incra.gov.br/nead. Acesso em: 04 jan. 2003.

IBGE. Recenseamento Geral do Brasil de 1940. Série Regional, parte XIV, Espírito Santo. Rio de Janeiro, 1951.

. Pesquisa Agrícola Municipal, Produção Pecuária Municipal e Produção do Extrativismo Vegetal e Silvicultura, 2013. Disponível em: www.ibge.gov.br. Acesso em: 20 de out. 2014.

. Censo Agropecuário, 1960 a 2006. Disponível em: www.ibge.gov.br. $\overline{\text { Acesso em: } 20}$ de out. 2014.

Censo Demográfico, 1960 a 2010. Disponível em: www.ibge.gov.br. Acesso em: 20 de out. 2014.

JACOBSON, Ludmilla da Silva Viana et al. Comunidade pomerana e uso de agrotóxicos: uma realidade pouco conhecida. Ciência e Saúde coletiva [online]. 2009, vol.14, n.6, pp. 2239-2249. ISSN 1678-4561.

IOTTI, Luiza Horn, org. Imigração e colonização: legislação de 1747 a 1915. Porto Alegre: Assembleia Legislativa do Estado do RS - Caxias do Sul: EDUSC, 2001.

IJSN. Programa de Desenvolvimento Regional Integrado. Relatório Municipal de Santa Leopoldina. Vitória, 1983. 80p.

KOWARICK, Lúcio. Trabalho e vadiagem - A origem do trabalho livre no Brasil. 2. ed. Rio de Janeiro: Paz e Terra, 1994.

KRUGER, Manfredo. Entrevista concedida a Márcia Cristina Bergamin. Santa Maria de Jetibá/ES, 20 jan. 2014.

LEITE, Sérgio. Padrão de financiamento, setor público e agricultura no Brasil. In: LEITE, Sérgio (Org.). Políticas públicas e agricultura no Brasil. Porto Alegre: Editora da Universidade/UFRGS, 2001.

LENCIONI, Sandra. Condições gerais de produção: um conceito a ser recuperado para a compreensão das desigualdades de desenvolvimento regional. Scripta Nova. Revista electrónica de geografía y ciencias sociales. Barcelona: Universidad de Barcelona, 1 de agosto de 2007, vol. XI, núm. 245 (07). Disponível em: http://www.ub.es/geocrit/sn/sn-24507.htm.

MACEDO, Fernando Cézar de. História econômica e organização espacial: o caso capixaba. Goiânia: Gráfica e Editora América/Institituto Histórico e Geográfico do Espírito Santo, 2003. 
MARTINS, José de Souza. A imigração e a crise do Brasil agrário. São Paulo: Livraria Pioneira, 1973.

. Os camponeses e a política no Brasil: as lutas sociais no campo e seu lugar no processo político. 2. ed. Petrópolis: Vozes, 1983.

. O Cativeiro da Terra. 4. ed. São Paulo: HUCITEC, 1990.

. Expropriação e Violência: a questão política no campo. 3. ed. rev. e aum. São Paulo: HUCITEC, 1991.

. O poder do atraso: ensaios de sociologia da história lenta. 2. Ed. São Paulo: HUCITEC, 1999.

MARTINS, Rodrigo Constante. Modernidade e temporalidade no trabalho agrícola. Teoria e Pesquisa: Revista de Ciência Política. São Carlos/SP: UFSCAR, oㅜ 49, p. 67-87, jul/dez de 2006. Disponível em: http://www.teoriaepesquisa.ufscar.br/index. $\mathrm{php} / \mathrm{tp} /$ article/viewFile/20/12.

MARTINS, Sonia Santana. Cadeias produtivas do frango e do ovo: avanços tecnológicos e sua apropriação. São Paulo, 1996. Tese (Doutorado em Economia) Escola de Administração de Empresas de São Paulo, Fundação Getúlio Vargas.

MARX, Karl. Manuscritos econômicos-filosóficos e outros textos escolhidos. 2.ed. Seleção de textos de José Arthur Giannotti/Tradução de José Carlos Bruni et alii. São Paulo: Abril Cultural, 1978.

Grundrisse: manuscritos econômicos de 1857-1858: esboços da crítica da economia política. Supervisão editorial Mario Duayer. Tradução Mario Duayer, Nélio Schneider (colaboração de Alice Helga Werner e Rudiger Hoffman). São Paulo: Boitempo; Rio de Janeiro: Ed. UFRJ, 2011.

MENEGUELI, Hélio Orlando. Certificação orgânica: desafios e oportunidades para a agricultura familiar. Experiência da associação CHÃO VIVO. IN: KÜSTER, Ângela; MARTÍ, Jaime Ferré. Agricultura familiar, agroecologia e mercado no Norte e Nordeste do Brasil. Fortaleza: Fundação Konrad Adenauer/DED, 2004, p. 169-182.

MORANDI, Ângela. Na mão da história: a CST na siderurgia mundial. Vitória: EDUFES, 1997.

MOREIRA, Vânia Maria Lousada. A ilusão das terras devolutas. In: CONGRESSO BRASILEIRO DE SOCIOLOGIA, 11, 2003, Campinas. Anais...: Campinas: Sociedade Brasileira de Sociologia, UNICAMP, 2003.

NAKANO, Octávio. As pragas das hortaliças: seu controle e o selo verde. Horticultura Brasileira, Brasília, v. 17, n. 1, p. 04-05, março 1999. 
PACHECO, Renato José. Os primeiros anos: conflito nas colônias agrícolas do Espírito Santo (1887 a 1882). In: Estudos em homenagem a Ceciliano Abel de Almeida. Vitória: FCCA, 1978, p. 123-148.

MEDEIROS, Marlon Clóvis; PADILHA, Wilian. Os ciclos de desenvolvimento do cooperativismo agropecuário e o crédito rural no Sudoeste do Paraná. Geosul, Florianópolis, v. 29, n. 58, p 185-204, jul./dez. 2014. PANAGIDES, Stahis. Erradicação do café e diversificação da agricultura brasileira. In: Revista Brasileira de Economia. Rio de Janeiro, vol. 23 (1), p. 41-71, jan/mar de 1969.

NERY, M.C.; NERY, F.C.; GOMES, L.A.A. O mercado e a participação de sementes de hortaliças no Brasil. 2007. Disponível em: <http://www.infobibos.com/Artigos/ 2007_1/sementes/index.htm>. Acesso em: 20 nov. 2014.

PEDEAG. Plano Estratégico de Desenvolvimento da Agricultura Capixaba. Avicultura/Suinocultura. Vitória: Governo do Estado do Espírito Santo, 2003. Disponível em: www.incaper.es.gov.br/pedeag. Acesso em 10/10/2003.

PETRONE, Maria Thereza Schorer. O imigrante e a pequena propriedade. São Paulo: Brasiliense, 1983.

PETRONE, Pasquale. Aspectos geográficos da área de colonização antiga do estado do Espírito Santo. Vitória: IHGES, 2004.

RIBEIRO, Diones Augusto. Busca à "primeira grandeza": o Espírito santo e o governo Moniz Freire (1892 a 1896). Vitória, 2008. Dissertação (Mestrado em História) Centro de Ciências Humanas e Naturais, Universidade Federal do Espírito Santo.

RIBEIRO Luiz Cláudio Moisés. O casamento das elétricas capixabas: um estudo da história da ESCELSA Espírito Santo Centrais Elétricas S/A (1951-1968). Niterói, 2003. Tese (Doutorado em História) - Instituto de Ciências Humanas e Filosofia, Universidade Federal Fluminense.

ROCHA, Aroldo Corrêa; COSSETTI, Maria da Penha. Dinâmica Cafeeira e constituição de indústrias no Espírito Santo - 1850/1930. Vitória: Núcleo de Estudos e Pesquisas/Departamento de Economia da UFES, 1983.

ROCHA, GILDA. Imigração estrangeira no Espírito Santo: 1847-1896. Vitória: \{s.n\}, 2000.

ROCHE, Jean. A colonização alemã no Espírito Santo. São Paulo: Difusão Europeia do Livro, Editora da Universidade de São Paulo, 1968.

SALETTO, Nara. Trabalhadores nacionais e imigrantes no mercado de trabalho no Espírito Santo (1888-1930). Vitória: EDUFES, 1996a.

- Transição para o trabalho livre e pequena propriedade no Espírito Santo (1888-1930). Vitória: EDUFES, 1996b. 
SACK, Robert David. O significado de territorialidade. In: DIAS, Leila Christina; FERRARI, Maristela (Orgs.). Territorialidades humanas e redes sociais. Florianópolis: Insular, 2.ed. rev., 2013.

SANTOS, José Vicente Tavares dos. Colonos do vinho: estudo sobre a subordinação do trabalho camponês ao capital. São Paulo: HUCITEC, 1978.

SAQUET, Marcos Aurélio. Campo-território: considerações teórico-metodológicas. Campo-Território: Revista de Geografia Agrária, Uberlândia, v.1, n.1, 2006. Disponível em: http://www.seer.ufu.br/index.php/campoterritorio/article/view/11780/6894. Acesso em 10/01/11.

SARTÓRIO, Élvio Antônio. A trilha sagrada: anatomia histórica das estradas: compêndio, história e monografia. Vitória: Ed. do Autor, 2007. 2v.

SCHNEIDER, Sérgio. Agricultura familiar e industrialização: pluriatividade e descentralização industrial no Rio Grande do Sul. Porto Alegre: Editora da Universidade/UFRGS, 1999.

SCHWARZ. Francisco. O município de Santa Leopoldina. 1992.

SCHWARZ, Francisco. O município de Santa Maria de Jetibá: o município mais pomerano do Espírito Santo. -. [Vitória]: [s.n.], 1993. 96 p.

SEIDE, Frederico Herdmann. Colonização alemã no Espírito Santo. 1980. Disponível em http://www.estacaocapixaba.com.br/. Acesso em 10/12/2012.

SEYFERTH, Giralda. A colonização alemã no Vale do Itajaí-Mirim: um estudo de desenvolvimento econômico. Porto Alegre: Movimento, 1974.

SHULTZ, Decimar. Entrevista concedida a Márcia Cristina Bergamin, Vitória, 10 jan. 2013.

SILVA, Martinho de Almeida e. Evolução do melhoramento genético de aves no Brasil. Revista CERES. Belo Horizonte v. 4, no. 56, p. 437-445, Jul./Ago. 2009.

SORJ, Bernardo; POMPERMAYER, Malori José, CORADINI e Odacir Luiz. Camponeses e Agroindústria: transformação social e representação política na avicultura brasileira. Rio de Janeiro: Zahar Editores, 1982.

SOUZA, José Marcelo Lopes de. O território: sobre espaço e poder, autonomia e desenvolvimento. In: CASTRO, Iná Elias; GOMES, Paulo César da Costa; CORRÊA, Roberto Lobato. Geografia: conceitos e temas. Rio de Janeiro: Bertrand Brasil, 2001, p. 77-116.

SOUZA FILHO, Hildo Meireles. A modernização violenta: principais transformações na agricultura capixaba. Campinas, 1990. 201f. Dissertação (Mestrado em Economia), Instituto de Economia, Universidade de Campinas. 
TINÔCO, Ilda de Fátima Ferreira. Avicultura Industrial: Novos Conceitos de Materiais, Concepções e Técnicas Construtivas Disponíveis para Galpões Avícolas Brasileiros. Rev. Bras. Cienc. Avic., Campinas, v. 3, n. 1, p. 01-26, Jan. 2001. Disponível em: http://www.scielo.br/scielo.php?script=sci_arttext\&pid=S1516-635 X2001000100001\&lng=en\&nrm=iso. Acesso em 18/06/15.

TSCHUDI, Johann Jakov Von. Viagem à província do Espírito Santo: imigração e colonização suíça (1860). Vitória: Arquivo Público do Espírito Santo, 2004.

VALADÃO, Vanda de Aguiar. Assentamentos e sem-terra: a importância do papel dos mediadores. Vitória: EDUFES, 1999.

WANDERLEY, Maria de Nazareth Baudel. Em busca da modernidade social: uma homenagem a Alexander V. Chayanov. In: FERREIRA, Ângela Duarte Damasceno; BRANDENBURG, Alfio (Orgs.). Para pensar outra agricultura. Editora da UFPR, Curitiba, 1998.

WEGNER, Rubia Cristina. Direito Humano à Alimentação: marco conceitual e legal para a presença do setor público brasileiro no abastecimento de Frutas, Legumes e Verduras. Revista de Segurança Alimentar e Nutricional, Campinas: UNICAMP, v.18, n.v1, p.73-92, 2011.

WILKINSON, John; CASTELLI, Pierina German. A transnacionalização da indústria de sementes no Brasil: biotecnologias, patentes e biodiversidade. Rio de Janeiro: Action Aid Brasil, 2000.

Processo de trabalho "é atividade orientada a um fim para produzir valores de uso, apropriação do natural para satisfazer as necessidades humanas, condição universal do metabolismo entre o homem e a natureza, condição natural eterna da vida humana e, portanto, independente de qualquer forma dessa vida, sendo antes igualmente comum a todas as suas formas sociais" (p. 303)

MARX, Karl. O capital: crítica da economia política, vol I, livro primeiro O processo de produção do capital 